\title{
COMPETITIVENESS REPORT 2020 FOCUS ON SERVICE SECTOR
}

\section{POLAND}

\author{
Edited by \\ Arkadiusz Michał Kowalski \\ Marzenna Anna Weresa
}




\section{SGH}

\section{WORLD ECONOMY RESEARCH INSTITUTE}

The World Economy Research Institute (WERI), a unit of the SGH Warsaw School of Economics, conducts research on the global economy and on international economic and financial relations, analyzing their impact on the Polish economy.

The institute's research focuses on the global aspects of economic development, foreign trade and foreign direct investment, as well as innovation processes and their impact on competitiveness. Selected regions of the global economy are analyzed in depth, in particular the economic development of Poland and other Central and Eastern European countries, Germany, the United States and East Asian states.

Research results are published in numerous books and reports and in the Working Papers series in Polish and English, which is available online at:

http://kolegia.sgh.waw.pl/pl/KGS/struktura/IGS-KGS/publikacje/

World Economy Research Institute

SGH Warsaw School of Economics

24 Rakowiecka St.

02-521 Warsaw, Poland

tel. +48225649370

e-mail:weri@sgh.waw.pl

http://kolegia.sgh.waw.pl/en/KGS/structure/IGS-KGS/ 


\section{COMPETITIVENESS REPORT 2020 \\ FOCUS ON SERVICE SECTOR}





\section{COMPETITIVENESS REPORT 2020}

FOCUS ON SERVICE SECTOR

Edited by

Arkadiusz Michat Kowalski

Marzenna Anna Weresa 


\section{Reviewers}

Edward Molendowski

Jacek Tomkiewicz

\section{Proofreading}

RGR Ryszard Guz-Rudzki

(C) Copyright by Szkoła Główna Handlowa w Warszawie, Warsaw 2020 All rights reserved. Copying, reprinting and dissemination of the whole text or its parts without permission of the publisher is prohibited.

First edition

ISBN 978-83-8030-400-0

Oficyna Wydawnicza SGH - Szkoła Główna Handlowa w Warszawie 02-554 Warszawa, al. Niepodległości 162

www.wydawnictwo.sgh.waw.pl

e-mail: wydawnictwo@sgh.waw.pl

\section{Cover design}

Ad Depositum

Layout and typesetting

DM Quadro

Printed and bound by

QUICK-DRUK s.c.

Order no. 105/X/20 


\section{Contents}

Preface

PART I. THE CONCEPT OF INTERNATIONAL COMPETITIVENESS

AND THE SERVICE SECTOR

Chapter 1. Competitiveness of the Service Sector - Concept Approach, Definition

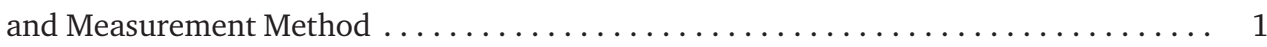

Marzenna Anna Weresa, Arkadiusz Michat Kowalski

Chapter 2. Changes in the EU Legal Framework

on the Provision of Services in the Internal Market in the Past Decade . .

Alina Szypulewska-Porczyńska

PART II. COMPETITIVENESS OF THE POLISH ECONOMY IN 2010-2019, WITH A PARTICULAR FOCUS ON THE SERVICE SECTOR

Chapter 3. Development of the Polish Economy in 2010-2019 Compared with Other EU Countries and Selected Emerging Markets, with a Particular Focus

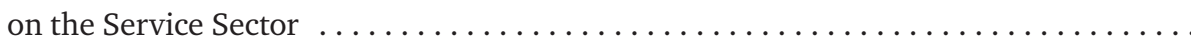

Ryszard Rapacki, Mariusz Próchniak

Chapter 4. Income Convergence of Poland to the Average EU Level

Mariusz Próchniak

Chapter 5. Income Inequality and Poverty in Poland in 2010-2018 . .

Patrycja Graca-Gelert

Chapter 6. Competitiveness of the Polish Service Sector in Foreign Trade 105 Mariusz Jan Radło

Chapter 7. The Link between Foreign Direct Investment in Services and the Competitiveness of the Polish Economy in the Service Sector.

A Comparative Analysis vis-à-vis the Visegrad Group Economies 121 Tomasz M. Napiórkowski 
PART III. KEY FACTORS OF COMPETITIVENESS OF THE POLISH ECONOMY IN 2010-2019 IN THE CONTEXT OF THE CHALLENGES FOR THE DEVELOPMENT OF THE SERVICE SECTOR

Chapter 8. Polish Economic Policy in the Context of the Development of the Service Sector . . . . . . . . . . . . . . . . . . . . . 143 Adam Czerniak, Ryszard Rapacki

Chapter 9. Investments and Financing the Development of the Service Sector in Poland 157

Piotr Maszczyk

Chapter 10. Labor Market Challenges in the Context of Employment Shifts in the

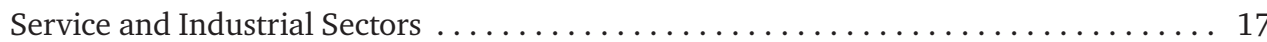
Anna Maria Dzienis

Chapter 11. Changes in Total Factor Productivity, with a Particular Focus on the Service Sector 183

Mariusz Próchniak

\section{PART IV. SERVICE SECTOR DEVELOPMENT TRENDS AND CHALLENGES}

Chapter 12. New Tendencies in International Service Flows 207 Andżelika Kuźnar

Chapter 13. Service Sector Development Directions and Barriers in Poland 225 Arkadiusz Michat Kowalski, Marta Mackiewicz, Marzenna Anna Weresa

Chapter 14. Innovativeness of Service Sector Enterprises in Poland 245 Małgorzata Stefania Lewandowska

\section{SUMMARY}

Competitive Position of Poland in 2019 (with a Focus on the Competitiveness of the Service Sector) 273 Marzenna Anna Weresa, Arkadiusz Michał Kowalski 


\section{Preface}

For many years, macroeconomic research used to focus on the industrial sector, whose productivity was considered to be a cornerstone of economic development. Along with a growing share of services in the economy, the sector's competitiveness was becoming increasingly important. That said, it should be noted that services are one of those economic activities that undergo the most profound transformations, linked to the introduction of innovations. While the increasing expansion of the service sector is seen to unfold with economic development, it is not only the development of the sector as a whole that plays a key role from the perspective of the competitiveness of the economy but also, and above all, the growth dynamics of certain types of services. One of the most dynamic segments of this sector consists of knowledge-intensive services, where knowledge is both the main factor of production and the essential good offered to customers. Among knowledge-intensive services, business services are a specific group engaging high-quality labor resources, while supporting the development of other industries in the manufacturing and service sectors.

Despite the growing economic and social importance of services, there is still a significant research gap regarding their importance for the international competitiveness of the economy. The question therefore arises: "How can the service sector contribute to increasing the competitive advantage in today's global economy?" An answer to this question has been sought in carrying out the study presented in this monograph. Its main objectives are to:

- lay down the theoretical background of the issue of international competitiveness, taking into account the latest developments in research,

- identify the international competitive position of Poland compared to other European Union member states and selected emerging economies;

- determine the degree of the service sector development in Poland, with a special focus on knowledge-based services, including, in particular, business services, and to assess their importance from the perspective of the competitiveness of the economy;

- identify the priorities of economic policy for the development of the service sector in Poland. 
The monograph consists of four parts divided into chapters. Part I (Chapters 1 and 2), proposes a definition of the service sector, with a particular focus on knowledge-intensive services, including business services, and characterizes traditional and contemporary dimensions of competitiveness in the context of that sector. In addition, the legal framework for the provision of services in the EU internal market is described.

Part II of the monograph focuses on determining the competitive position of the Polish economy compared with other European Union member states and selected emerging markets. The starting point is an outline of Poland's development tendencies in 2010-2019 (Chapter 3) and an analysis of the convergence of income in Poland with the average EU level in the long term (Chapter 4). In line with a modern, comprehensive approach to the analysis of international competitiveness, which goes beyond the income dimension, so as to include also social categories, Chapter 5 addresses the problem of income disparities and poverty level in Poland. The decomposition of income for socio-economic groups and regions is performed, and the direct impact of the child support benefit under the "Family 500+" program on income disparities is shown. Part II ends with chapters referring to Poland's international relations, i.e., competitiveness of the Polish service sector in foreign trade (Chapter 6) and the link between foreign direct investment in the sector and the competitiveness of the Polish economy (Chapter 7).

Part III of the monograph is devoted to the main factors of Poland's competitiveness, taking into account challenges related to the development of the service sector. The following chapters present an analysis of the Polish economic policy in the context of development of service industries (Chapter 8), investment and financing of the service sector in Poland (Chapter 9), and the situation in the Polish labor market (Chapter 10). The last chapter of this part sums up the analyses presented, depicting changes in total factor productivity in Poland, with a particular focus placed on the service sector (Chapter 11).

Part IV of the monograph provides an overview of selected issues affecting the competitiveness of the service sector in Poland. The considerations presented here start with a description of the latest tendencies in international trade in services described in Chapter 13. It also contains the results of an analysis involving new ways of measuring international trade in services, which allowed the value of services to be estimated with greater accuracy, both based on the definition provided in the General Agreement on Trade in Services (GATS) and according to value added. Chapter 13 focuses on challenges related to the development of services in Poland, addressing especially knowledge-intensive services and knowledge-intensive business services. 
are. The last chapter of the monograph presents the innovation performance of Polish service sector enterprises.

The monograph ends with final conclusions which include also those relating to economic policy aimed at supporting the service sector in Poland.

Arkadiusz Michał Kowalski Marzenna Anna Weresa 

Part I

The Concept of International Competitiveness and the Service Sector 

Chapter 1

\title{
Competitiveness of the Service Sector \\ - Concept Approach, Definition and Measurement Method
}

\author{
Marzenna Anna Weresa, Arkadiusz Michał Kowalski
}

\subsection{Introduction}

In today's economy, we are witnessing the process of servitization, which is expressed by a growing share of the service sector in the economy, alongside the expansion of service functions in industry and agriculture. Changes in management practices manifest themselves through convergence between production and services. In many respects, traditional boundaries between services and the manufacturing industry are becoming less clear. On the one hand, industrialization of services is seen to be in progress, and, on the other hand, a growing emphasis is placed on the service component in manufacturing activities, which is often linked to the development of new technologies. The industrialization of services means that many of what used to be "craft" processes in services have been undergoing changes that unfold in a way typical of various categories of manufacturing. These observations point to the growing importance of the service sector from the socio-economic development perspective.

As the share of services in the economy increases, the competitiveness of the sector has been gaining in importance, which can be considered at the level of both the economy as a whole and of the various service industries, as well as in microeconomic terms, i.e., taking into account the enterprises active in the sector

The question therefore arises: "How to define and measure the competitiveness of services not only within the whole economy, but also from the point of view of specific service industries?" The aim of the analysis presented in this chapter is to outline the conceptual framework for exploring the competitiveness of the service sector, especially at a time of progressing digitalization of economies.

The starting point for further analyses in this and subsequent chapters is the definition of the service sector, with a particular focus on knowledge-intensive services, and the determination of the importance of the service sector in the economy. The 
chapter then characterizes the traditional and contemporary dimensions of competitiveness in the context of the service sector. The chapter ends with conclusions on the specificities of services and their competitiveness.

\subsection{Definition of the Service Sector}

Services are often defined in conjunction with the purposes they serve. Based on this criterion, four main groups of services are identified [Katouzian, 1970; Castells, 1996]. They include:

- services related to the distribution of goods (e.g., trade, transport);

- services representing inputs necessary for the production of goods (e.g. engineering, banking, insurance services);

- social services (e.g., education, medical services);

- personal services (e.g., hotel, beauty services).

Polish statistics follow a definition of services laid down in the Regulation of the Council of Ministers of 4 December 2015 on the Polish Classification of Goods and Services (PKWiU) (Journal of Laws, 2015, item 1676). It is based on a broad approach according to which services are activities that do not directly create new tangible goods, provided both to businesses and to other entities of the national economy, and to the population.

According to PKWiU (Journal of Laws, 2015, item 1676, p. 14), there are three groups of services:

- production services provided for the purposes of business entities;

- consumer services provided to satisfy the needs of the population;

- collective services aimed to satisfy public order and organizational needs of the national economy and society at large.

It is worth making a distinction between the concept of service and the concept of service activity. A definition of the latter is provided in the Polish Classification of Activities (PKD), set forth in the Regulation of the Council of Ministers of 24 December 2007 (Journal of Laws, 2007, No. 251, item 1885), which corresponds to the Statistical Classification of Economic Activities in the European Community - NACE (French: Nomenclature statistique des Activités économiques dans la CommunautéEuropéenne). According to the arrangements adopted, service activities include the following NACE Rev. 2 sections:

- $\mathrm{H}$ : transportation and storage;

- I: accommodation and food service activities;

- J: information and communication; 
- K: financial and insurance activities;

- L: real estate activities;

- M: professional, scientific and technical activities;

- $\mathrm{N}$ : administrative and support service activities.

Attention is drawn in the economic literature to an important aspect, namely the fact that production and consumption of services are interlinked and the need for direct interactions between the service producer and the consumer [Crespi et al., 2006].

Services can be defined by identifying their main characteristics, such as significant heterogeneity, intangibility, non-storability, simultaneous occurrence of production, distribution and consumption [Gustafsson and Johnson, 2003]. A characteristic that differentiates services from manufacturing is their high divergence in terms of capital intensity and knowledge intensity [Miles, 2004].

\subsection{The Nature of Knowledge-Intensive Services (KIS) and Knowledge-Intensive Business Services (KIBS)}

Knowledge-intensive services are one of the most dynamic segments of the service sector. However, the literature lacks a precise definition; in general, they can be described as services based on specialized knowledge, designed to solve problems or meet customers' needs [Grönroos, 2011; Normann and Ramirez, 1994; Brandl, 2019]. Various characteristics are assigned to knowledge-intensive services, in particular that knowledge is both their main production factor and an essential good offered to recipients. According to Kemppilä and Mettänen [2004], knowledge-intensive services are based on the competence of their providers and constitute an important source of knowledge for customers. In addition, there is an intensive interaction between those two groups, enabling new knowledge to be created and diffused. It should be noted, however, that knowledge-intensive services are based on information asymmetry between service providers and customers, generated by skills and competences, management systems and expert knowledge resources [Grönroos, 2011]. The services can be provided by a single professional (e.g. a lawyer or research analyst), but they are usually provided by a team of experts [Brandl 2019]. The literature highlights the high significance of knowledge-intensive service providers in innovation systems [Miles et al., 1995], who can:

- be a source of innovation by initiating innovation activities in the recipient's organization;

- facilitate the implementation of innovations by stimulating innovative processes of other entities; 
- be innovation carriers by taking measures to transfer existing knowledge between different entities it can be applied in a new context.

Tether and Hipp [2002] emphasize the importance of professional knowledge relating to a specific technical or functional domain, and the fact that knowledge-intensive services make an important contribution to the development of products or production processes of other enterprises (such as communication and computer services). At the same time, knowledge-intensive services maintain many characteristics of the service sector in more general terms, e.g. the fact that $\mathrm{R} \& \mathrm{D}$ activities rarely originate within research and development departments [Miles et al., 1995]. Among factors driving the development of the knowledge-intensive service sector, Miles, Belousova and Chichkanov [2018] mention:

- growing demand from organizations which concentrate on their key competences, outsourcing non-core business to specialized suppliers;

- increasing requirements for external knowledge;

- evolving environment and technologies which require access to knowledge to enable them to be fully used;

- increasing complexity of economies and the technologies they employ.

A classification of knowledge-intensive services and corresponding NACE Rev. 2 divisions are presented in Table 1.1.

Table 1.1. Categories of knowledge-intensive services and corresponding industries

\begin{tabular}{|c|c|c|}
\hline Category & $\begin{array}{c}\text { NACE } \\
\text { Rev. } 2 \\
\text { division }\end{array}$ & Name of NACE Rev. 2 division \\
\hline \multirow{9}{*}{$\begin{array}{l}\text { Knowledge-based } \\
\text { market services } \\
\text { (excluding financial } \\
\text { and high-tech } \\
\text { services) }\end{array}$} & 50 & water transport \\
\hline & 51 & air transport \\
\hline & 69 & legal and accounting activities; tax consultancy \\
\hline & 70 & activities of head offices; management consultancy activities \\
\hline & 71 & architectural and engineering activities; technical testing and analysis \\
\hline & 73 & advertising, market research and public opinion polling \\
\hline & 74 & other professional, scientific and technical activities \\
\hline & 78 & employment activities \\
\hline & 80 & security and investigation activities \\
\hline \multirow[t]{6}{*}{ High-tech services } & 59 & motion picture and sound recording activities \\
\hline & 60 & programming and broadcasting activities \\
\hline & 61 & telecommunications \\
\hline & 62 & computer programming, consultancy and related activities \\
\hline & 63 & information service activities \\
\hline & 72 & scientific research and development \\
\hline
\end{tabular}




\begin{tabular}{|l|c|l|}
\hline \multicolumn{1}{|c|}{ Category } & $\begin{array}{r}\text { NACE } \\
\text { Rev. 2 } \\
\text { division }\end{array}$ & \multicolumn{1}{|c|}{ Name of NACE Rev. 2 division } \\
\hline $\begin{array}{l}\text { Knowledge-based } \\
\text { financial services }\end{array}$ & $64-66$ & financial and insurance activities (Section K) \\
\hline $\begin{array}{l}\text { Other knowledge- } \\
\text {-based services }\end{array}$ & 58 & publishing activities \\
\cline { 2 - 4 } & 75 & veterinary activities \\
\cline { 2 - 4 } & 84 & $\begin{array}{l}\text { public administration and defense, compulsory social security } \\
\text { (Section O) }\end{array}$ \\
\cline { 2 - 4 } & 85 & education (Section P) \\
\cline { 2 - 3 } & $86-88$ & human health and social work activities (Section Q) \\
\cline { 2 - 3 } & $90-93$ & arts, entertainment and recreation (section R) \\
\hline
\end{tabular}

Source: Eurostat, Eurostat indicators on High-tech industry and Knowledge - intensive services, Annex 3 - High-tech aggregation by NACE Rev. 2, https://ec.europa.eu/eurostat/cache/metadata/Annexes/htec_esms_an3.pdf (2020.02.25).

Knowledge-intensive business services (KIBS) are a specific group of knowledge-intensive services. They involve economic activities which are intended to result in the creation, accumulation or dissemination of knowledge [Braga, Marques and Serrasqueiro, 2018]. Knowledge-intensive business services can be distinguished from other knowledge-intensive services on the basis of criteria relating to the intensity of knowledge and satisfaction of intermediate demand. This allows characteristics to be identified that differentiate knowledge-intensive business services from other types of services [Miles et al., 1995, p. 28]:

- they rely heavily upon professional, specialist knowledge, which is reflected in the employment structures that are heavily weighted towards scientists, engineers, experts of all types;

- they are sources of information and knowledge for recipients (e.g., training, consultancy, measurements) or they are used to produce services which are intermediate inputs to their clients' own knowledge generating and information processing activities (e.g., communication and computer services);

- they are provided mainly to businesses and have a major bearing on their competitive position.

While Eurostat provides a precise classification of knowledge-intensive services (presented in Table 1.1), there is no uniform approach to which industries should be included among knowledge-intensive business services. Based on the literature review presented in Table 1.2, industries have been identified which are most often categorized as knowledge-intensive business services.

Knowledge-intensive business services are a part of the service business which is highly innovative and facilitates the implementation of new solutions in other organizations. They play a significant role in innovation systems [Windrum and Tomlinson, 
1999], particularly in developed regions where manufacturing competitiveness depends on knowledge provided by highly specialized suppliers [Braga, Marques and Serrasqueiro, 2018, p. 360). Knowledge-intensive business services facilitate innovation processes by interfacing between the generic knowledge available in the economy and the tacit knowledge accumulated by enterprises.

Table 1.2. Knowledge-intensive business services

\begin{tabular}{|l|l|l|}
\hline \multirow{2}{*}{ NACE Rev. 2 section } & $\begin{array}{c}\text { NACE } \\
\text { Rev. } 2 \\
\text { division }\end{array}$ & \\
\hline \multirow{2}{*}{$\begin{array}{l}\text { Section J - information } \\
\text { and communication }\end{array}$} & 62 & computer programming, consultancy and related activities \\
\cline { 2 - 3 } & 63 & information service activities (data processing, hosting, web portals) \\
\hline \multirow{2}{*}{$\begin{array}{l}\text { Section M: } \\
\text { professional, scientific } \\
\text { and technical activities }\end{array}$} & 69 & legal and accounting activities; tax consultancy \\
\cline { 2 - 3 } & 71 & activities of head offices; management consultancy activities \\
\cline { 2 - 3 } & 72 & $\begin{array}{l}\text { architectural and engineering activities; technical testing and } \\
\text { analysis }\end{array}$ \\
\cline { 2 - 3 } & 72 & $\begin{array}{l}\text { research and experimental development (on natural sciences and } \\
\text { engineering and on social sciences and humanities) }\end{array}$ \\
\cline { 2 - 3 } & 73 & advertising, market research and public opinion polling \\
\cline { 2 - 3 } & 74 & other professional, scientific and technical activities \\
\hline
\end{tabular}

Source: Own study based on: Schnabl and Zenker [2013]; Lafuente and Vaillant y Vendrell Herrero [2017].

Although knowledge-intensive business services represent only a small proportion of all services, their significance is greater than implied by their share in employment or value added, as they are increasingly often a source of crucial new technologies that influence the whole economy. Instead of providing standard services, they allow available expertise to be integrated with specialized knowledge and provide access to customized solutions to clients' requirements [Tether and Hipp, 2002]. What also contributes to a dynamic development of knowledge-intensive business services are such factors as growing demand for services supporting economic processes, reorganization of production through outsourcing, and the development of information and communication technologies (ICT).

\subsection{Competitive Advantages in the Service Sector}

Services play diverse roles in the economy. The most important ones include those supporting manufacturing, administration and organization, research, social, domestic, culture-forming and educational processes [Rogoziński, 2000]. The development 
of the service sector, in particular those necessary for all economic activities, such as financial services, telecommunications, transport, logistics, can stimulate economic growth and exports, and drive the diversification of economic activities. Many countries, especially developing ones, take advantage of new opportunities to export services, develop value chains or integrate them into service activities, usually through the development of traditional domains, such as tourism and transport (Hollweg and Sáez, 2019]. Improvement of the quality of services contributes to a company's shift within the value chain in industries where the country already has a technological potential and comparative advantage. However, it is not possible for this to translate, in a short term, into an increase in product differentiation in industries where the country does not have a competitive advantage [Nordås and Kim, 2013]. Diversification in these industries may take place gradually, tending to stretch over a longer time horizon.

In conclusion, at least two aspects of services can be distinguished as a factor determining the competitiveness of economies. Firstly, they can be a strategic driver of competitiveness for the economy as a whole. Secondly, a country with a comparative advantage in trade in services can export them, thereby diversifying the structure of the export sector and, in the longer term, the economy as a whole [Sáez et al., 2014; Hollweg and Sáez, 2019].

Competitive advantages of countries in the service sector should be considered in conjunction with the productivity of factors of production used in the production and provision of services, as it is productivity that determines the competitiveness of economies [Porter, 1990; 2008]. At this point, however, it is worth pointing out the differences in productivity and its dynamics between the industry and service sectors [Schettkat and Yocarini, 2003, p. 33]. The main determinants of a smaller productivity growth rate in the service sector compared with industry include a lower impact of technological changes on services, relative lower innovation performance, the occurrence of smaller economies of scale, and slower improvement of workforce quality than in industry [Skórska, 2016, p. 9]. In addition, the rate and changes in productivity are different for each type of services. The literature on trade in services has empirically proven that exporters of services are more productive than firms operating exclusively in the local market [Breinlich and Criscuolo, 2011; Ariu, 2016]. In addition, exporters of advanced services (excluding transport, tourist services and distribution) are more productive than exporters of other services [Hollweg and Sáez, 2019]. As regards service activities in international markets, competitive advantages are based mainly on skills and experience in the professional provision of services, their high quality, customers' confidence in the service provider, and the efficiency of service delivery.

Innovations are a major factor driving the competitiveness of the service sector [Schettkat and Yocarini, 2003; OECD, 2005; Gustafsson and Johnson, 2002]. This 
observation leads to the conclusion that in advanced economies an improvement of the competitiveness of service industries is possible to achieve by implementing new solutions. However, innovations in the service sector are of a specific nature. Sundbo and Gallouj [2001] present a list of typical innovation patterns in services, demonstrating that they rely more on organizational and human elements and on interactiveness, and less on technology.

\subsection{Traditional and Contemporary Dimensions of the Competitiveness of Services}

\section{Income competitiveness}

One of the traditional dimensions of competitiveness is income competitiveness, which concerns the ability of an economy to ensure a particular level of income so as to provide a particular standard of living for the population. At the same time, it is pointed out that the share of the service sector in the economy is growing with the wealth of countries [ (Herrendorf, Richard and Valentinyi, 2014], and the positive relationship between the participation of the service sector in production and income per capita is one of the best-known regularities in economics [Eichengreen and Gupta, 2013]. It can therefore be assumed that the degree of servitization of the economy, expressed, inter alia, by the share of the service sector in the economy (measured, e.g., by the share of the service sector in the creation of GDP or value added), is in itself an indicator of international competitiveness, closely linked to income competitiveness.

The basic measure of income competitiveness, and one of the most frequently used macroeconomic indicators, is the volume of GDP per capita in purchasing power parity (PPS). This measure has long remained an indicator of the division into developed and developing countries, showing polarization in the socio-economic development of individual countries [Kowalski, 2020]. Although GDP per capita is one of the most widely used measures in research on international competitiveness, this indicator has various limitations. For example, it does not fully reflect the actual state of the economy, competitiveness factors and many important aspects of the quality of life of the population, e.g., income inequalities between different social groups. Moreover, GDP per capita is unreliable when assessing one of the most important elements of today's economies, namely innovation [Coyle, 2015]. All the constraints in determining socio-economic success through the lens of income competitiveness have contributed to the development of research into other dimensions of competitiveness described further on in the chapter. 


\section{Trade competitiveness in services}

The international dimension of the competitiveness of national economies is usually analyzed in relation to foreign trade and involves effective competition in the global market [Misala, 2014]. International trade in services is steadily increasing, and offshoring services is affecting the development of the sector and providing countries with opportunities to become more involved in the international division of labor.

The specific characteristics of services, such as intangibility, non-storability, or diversification in terms of capital and knowledge intensity, determine the development of international trade in services and the sources of competitive advantages in the service sector. Not all types of services are subject to international exchange. For example, personal services (beauty, hairdressing, medical, retail services), addressing individual local consumers, are not broadly integrated into international economic exchange.

The key indicators used to assess international trade in services are the value of exports and imports of services and their share in total trade and in relation to GDP, the dynamics of trade in services, the balance of trade in services. As in trade in goods, a useful and frequently used competitiveness measure is the indicator of the Revealed Comparative Advantages and its various variations resulting from the transformation of the original Balassa formula [1965]. The index allows the identification of industries in which a country gains advantages in exporting or trading in international markets. It is possible to shape these advantages through an active innovation and trade policy tailored to the needs of the economy.

\section{Investment competitiveness}

In today's global economy, different countries and regions compete for capital in an effort to ensure the best possible conditions for attracting investment, in particular foreign direct investment. Economic policy of many governments is moving towards liberalization, promotion and facilitation of investment. This is reflected in removing or reducing entry restrictions for foreign investors in various industries, simplifying and streamlining administrative procedures, and introducing tax incentives for investment [United Nations, 2019]. In view of the various benefits of capital inflows, investment competitiveness, which the World Bank [World Bank, 2018] has defined as the ability of countries not only to attract but also to retain and integrate private investment, is therefore an important dimension of international competitiveness.

In recent years, foreign direct investment in the service sector has increased particularly rapidly and foreign service providers have played an important role in view 
of the growing range of services offered in national markets. This largely reflects the inalienable nature of many types of services, which, unlike industrial products, cannot be stored, so they must be produced at the place and time of their consumption [UNCTAD, 2004]. These services are location-bounded, non-tradable and require face-to-face contact between the service provider and the customer [Ramasamy and Yeung, 2010]. Therefore, the main way to bring services to foreign markets is foreign direct investment, in particular, offshoring. At the same time, these services can bring significant benefits to host economies, such as the transfer of capital, skills and technologies needed to increase the efficiency of the service sector and thus improve international competitiveness [UNCTAD, 2004].

An important determinant of investment competitiveness is the investment climate, understood as the entirety of conditions characteristic of a given economy from the perspective of the performance of the objective function by a foreign investor. The components of the investment climate are presented in Table 1.3.

Table 1.3. Investment climate components

\begin{tabular}{|l|l|}
\hline $\begin{array}{c}\text { Type of investment } \\
\text { climate }\end{array}$ & \multicolumn{1}{c|}{ Example determinants } \\
\hline Political climate & $\begin{array}{l}\text { political stability, historical conditionality, the importance of the private sector } \\
\text { in the economy }\end{array}$ \\
\hline Social climate & $\begin{array}{l}\text { situation in the labor market, education and age structure of the labor force, the } \\
\text { attitude of the public to private property }\end{array}$ \\
\hline Economic climate & $\begin{array}{l}\text { the country's economic stability, size and absorbency of market outlets, available } \\
\text { technical infrastructure and the infrastructure of the business environment }\end{array}$ \\
\hline $\begin{array}{l}\text { Administrative } \\
\text { climate }\end{array}$ & $\begin{array}{l}\text { quality of administrative procedures, influence of the administration on business } \\
\text { performance, provisions regulating the transfer of profits }\end{array}$ \\
\hline Legal climate & quality, stability and transparency of laws and regulations \\
\hline
\end{tabular}

Source: Nehrt [1971].

Business entities planning investment seek to find a location that will allow business needs to be satisfied in an optimal way. However the desirable set of locational factors differs depending on the specialization of an enterprise. For many years, research on locational factors focused on the manufacturing sector. As nowadays foreign direct investment in the service sector is developing much faster than in the manufacturing sector, the focus of research on location choice has been shifting to the service sector [Duboz, Kroichvili and Le Gallo, 2019]. The key investment factors in services, the saturation of which can be measured by corresponding indicators include: [Bunyaratavej, Hahn and Doh, 2008]:

- quality ICT infrastructure (for the industrial sector, transport infrastructure, such as roads, is of greater significance); 
- high-quality human capital characterized by high skills (unlike industry, where vocational training matters most);

- quality real estates and rental office space (for the industrial sector, availability of greenfield/brownfield land is of greater significance).

\section{Sustainable competitiveness}

Sustainable competitiveness is defined by combining factors that determine the long-term improvement of the productivity while ensuring sustainable social and environmental development [Blanke et al., 2011; Corrigan et al., 2014]. The social component of sustainable competitiveness concerns security, healthcare, and reduction of social exclusion. In the context of services, it should be noted that components of sustainable competitiveness in its social dimension include the categories of services which are usually classified as social services (e.g., education, medical services) [Katouzian, 1970; Castells, 1996]. Depending on the solutions adopted in different countries, many of them, in particular ensuring security for citizens, fall within public services.

Sustainable competitiveness of the natural environment means effective management of natural resources, which ensures sustainable improvement of the social welfare [Corrigan et al., 2014, p. 55]: This area encompasses services involving the responsible use of resources such as water, air, natural raw materials (e.g. water treatment, air purification), and other services improving the quality of the natural environment.

One of the metrics of sustainable competitiveness is the Social Progress Index (SPI), which comprises indicators of the degree of satisfying basic human needs (primary education, health, security) and opportunities for personal development as well as sustainable improvement of social welfare (Porter, Stern and Green, 2015). The indicators contain a component related to social services.

\section{Technological and digital competitiveness}

Services are also involved in the technological and digital dimension of competitiveness. Technology development is not possible without research, engineering and consulting services. This applies in particular to information and communication services necessary for the development and application of information and communication technologies (ICT). The ICT industry deals with the production of hardware, software and associated services (e.g. programming) as well as service activities supporting ICT application (e.g. information and data collection, selection and processing services). In addition, appropriate solutions (e.g. data and information analysis, e-marketing, communication) are needed to ensure the use of digital technologies 
in the economy [OECD, 2016]. Therefore, new educational, consulting, mentoring, coaching services are emerging. Technological and digital competitiveness seems to rely on services, especially on knowledge-intensive services, even more than competitiveness defined in traditional terms.

\subsection{Conclusions}

This chapter discusses competitiveness issues in the context of the development of the service sector.

In recent decades, the competitiveness of businesses and economies has become an important, highly popular area of research, even though there is still a lack of a single, coherent theory that would fully describe this phenomenon. Globalization, strengthening of integration efforts, liberalization of markets, as well as political, economic and social developments over the last two decades, are conducive to the development of new dimensions of competitiveness, such as technological competitiveness and sustainable competitiveness. This does not mean that the traditional dimensions of competitiveness (income or investment) are becoming irrelevant. However, their substance is changing, as exemplified by the growing servitization of economies and the benefits and challenges involved.

It is apparent from the above literature review that competitiveness in the context of the service sector can be considered from several points of view. Firstly, the development of services, which are increasingly penetrating other sectors of the economy, can affect the competitiveness of both these sectors (industry, agriculture) and the economy as a whole. Secondly, when considering mesoeconomic competitiveness, it is possible to analyze the different dimensions of the competitiveness of services or selected groups of services (e.g. knowledge-intensive services) in a comparative perspective, with reference to the competitiveness of the sector in other countries. Thirdly, the service outsourcing and offshoring processes influence the dynamics of the development of the service sector, and indirectly affect its competitiveness.

Taking all these elements into account makes the analysis of the competitiveness of services a complicated and complex exercise.

\section{Bibliography}

Ariu, A. [2016], Services versus Goods Trade: A Firm-Level Comparison, "Review of World Economics", Vol. 152(1), pp. 19-41. 
Balassa, B. [1965], Trade Liberalization and 'Revealed' Comparative Advantage. "The Manchester School of Economic and Social Studies", Vol. 33(2), pp. 99-123.

Blanke, J. et al. [2011], The Long-Term View: Developing a Framework for Assessing Sustainable Competitiveness, in: The Global Competitiveness Report 2011-2012, World Economic Forum, Geneva, pp. 51-74.

Braga, A., Marques, C.S., Serrasqueiro, Z. [2017], Internationalisation Strategy of KnowledgeIntensive Business Services, "Journal of the Knowledge Economy”, Vol. 9(2), pp. 359-377.

Brandl, K. [2019], The impact of offshoring on knowledge-intensive services: A study of activities in service production processes, "Global Strategy Journal", Vol. 9(3), pp. 453-487.

Breinlich, H.M., Criscuolo, C. [2011], International Trade in Services: A Portrait of Importers and Exporters, "Journal of International Economics", Vol. 84(2), pp. 188-206.

Bunyaratavej, K., Hahn, E.D., Doh, J.P. [2008], Multinational investment and host country development: Location efficiencies for services offshoring, "Journal of World Business", Vol. 43(2), pp. 227-242.

Castells, M. [1996], The Rise of the Network Society, Blackwell Publishers, Malden \& Oxford, pp. 201-326.

Corrigan, G. et al. [2014], Assessing Progress toward Sustainable Competitiveness, in: Global Competitiveness Report 2014-2015, World Economic Forum, Geneva, pp. 53-83.

Crespi, G. et al. [2006], Measuring and Understanding Productivity in UK Market Services, "Oxford Review of Economic Policy", Vol. 22(4), pp. 560-572.

Djellal, F., Gallouj, F., Miles, I. [2013], Two decades of research on innovation in services: Which place for public services?, "Structural Change and Economic Dynamics", No. 27, pp. 98-17.

Duboz, M.L., Kroichvili, N., Le Gallo, J. [2016], Do foreign investors' location determinants in service functions differ according to sectors? An empirical analysis of EU for 1997 to 2011, "International Regional Science Review", Vol. 34(4), pp. 417-456.

Duboz, M.L., Kroichvili, N., Le Gallo, J. [2019], What matters most for FDI attraction in services: country or region performance? An empirical analysis of EU for 1997-2012, "The Annals of Regional Science", Vol. 63(3), pp. 1-38.

Eichengreen, B., Gupta, P. [2013], The two waves of service-sector growth, "Oxford Economic Papers", Vol. 65(1), pp. 96-123.

Eurostat, Eurostat indicators on high-tech industry and knowledge - intensive services, Annex 3 -High-tech aggregation by NACE Rev. 2, https://ec.europa.eu/eurostat/cache/metadata/ Annexes/htec_esms_an ${ }^{3}$.pdf (2020.02.25).

Figueiredo, R., de Matos Ferreira, J.J. [2019], Spinner Model: Prediction of Propensity to Innovate Based on Knowledge-Intensive Business Services, "Journal of the Knowledge Economy", pp. 1-20.

Grönroos, C. [2011], Value co-creation in service logic: A critical analysis, "Marketing Theory", Vol. 11(3), pp. 279-301.

Gustafsson, A., Johnson, M.D. [2003], Competing in a Service Economy, How to Create a Competitive Advantage Through Service Development and Innovation, John Wiley \& Sons, San Francisco. 
Herrendorf, B., Richard, R., Valentinyi, A. [2014], Growth and structural transformation, "Handbook of Economic Growth", Vol. 2(6), pp. 855-941.

Hollweg, C.H., Sáez, S. [2019], Services for Trade Competitiveness: Country and Regional Assessments of Services Trade (International Development in Focus), World Bank, Washington.

Katouzian, M.A. [1970], The Development of the Service Sector: A New Approach, "Oxford Economic Papers", Vol. 22(3), pp. 362-382.

Kemppilä, S., Mettänen, P. [2004], Innovations in knowledge-intensive services, in: Proceedings of the 5th International CINet Conference, 22-25 September, pp. 326-335.

Kowalski, A.M. [2020], Global South - Global North Differences, in: Encyclopedia of the UN Sustainable Development Goals. No Poverty, W.L. Filho et al. (eds.), Springer.

Lafuente, E., Vaillant, Y., Vendrell-Herrero, F. [2017], Territorial servitization: Exploring the virtuous circle connecting knowledge-intensive services and new manufacturing businesses, "International Journal of Production Economics", 192, pp. 19-28.

Mile, I., Belousova, V., Chichkanov, N. [2018], Knowledge intensive business services: ambiguities and continuities, "Foresight", Vol. 20(1), pp. 1-26.

Miles, I. [2004], Innovation in Services, in: Dodgson, M., Rothwell, R. (eds.) The Oxford Handbook of Innovation, Oxford University Press, Oxford-New York, Chapt. 16, pp. 433-458.

Miles, I. et al. [1995], Knowledge-Intensive Business Services: Users, Carriers and Sources of Innovation, EIMS Publication, No. 15.

Misala, J. (2014), Theoretical Grounds of the Development of Long-Term Competitive Advantages in International Trade, in: Innovation, Human Capital and Trade Competitiveness. How Are They Connected and Why Do They Matter?, Weresa, M.A. (ed.), Springer, Cham-HeidelbergNew York-Dordrecht-London, pp. 3-51.

Mistura, F., Roulet, C. [2019], The determinants of Foreign Direct Investment: Do statutory restrictions matter?, OECD Working Papers on International Investment, No. 2019/01, OECD Publishing, Paris.

Nehrt, L.C. [1971], The political climate for foreign investment, "The International Executive", Vol. 13(1), pp. 16-18.

Nordås, H., Kim, Y. [2013], The Role of Services for Competitiveness in Manufacturing, OECD Trade Policy Papers, No. 148, OECD Publishing, Paris.

Normann, R., Ramirez, R. [1994], Designing interactive strategy - From value chain to value constellation, Edward Elgar Publishing, Cheltenham.

OECD [2005], Promoting innovation in services, OECD Publishing, Paris.

OECD [2016], Skills for a Digital World, OECD Digital Economy Papers, No. 250, OECD Publishing, Paris.

Porter, M.E. [1990], The Competitive Advantage of Nations, Free Press, New York.

Porter, M.E. [2008], On Competition, Harvard Business School Publishing, Boston.

Porter, M. E, Stern, S., Green, M. [2015], Social Progress Index 2015. Social Progress Imperative, Washington, http://www.socialprogressimperative.org/publication/2015-report/ (11.02.2020). 
Ramasamy B., Yeung, M. [2010], The determinants of foreign direct investment in services, "World Economy", Vol. 33(4), pp. 573-596.

Rogoziński, K. [2000], Ustugi rynkowe, Akademia Ekonomiczna w Poznaniu, Poznań.

Regulation of the Council of Ministers of 24 December 2007 on the Polish Classification of Activities (PKD) (Journal of Laws, 2007, No. 251, item 1885).

Regulation of the Council of Ministers of 4 December 2015 on the Polish Classification of Goods and Services (PKWiU) (Journal of Laws, 2015, item 1676).

Sáez, S. et al. [2014], Valuing Services in Trade: A Toolkit for Competitiveness Diagnostics, World Bank, Washington.

Schettkat, R., Yocarini, L. [2003], The Shift to Services: A Review of the Literature, Discussion Paper, No. 964, The Institute for the Study of Labor, Bonn.

Schnabl, E., Zenker, A. [2013], Statistical Classification of Knowledge-Intensive Business Services (KIBS) with NACE Rev. 2, Karlsruhe: Fraunhofer Institute for Systems and Innovation Research ISI.

Skórska, A. [2016], Determinanty i perspektywy rozwoju sektora usług w Polsce - zmiany wewnątrzsektorowe, "Prace Komisji Geografii Przemysłu Polskiego Towarzystwa Geograficznego", Vol. 30(4), pp. 7-20.

Strambach, S. [2008], Knowledge-Intensive Business Services (KIBS) as drivers of multilevel knowledge dynamics, "International Journal of Services Technology and Management", No. 10, pp. 152-174.

Sundbo, J., Gallouj, F. [2001], Innovation as a Loosely Coupled System in Services, in: Innovation Systems in the Service Economy: Measurement and Case Study Analysis, Metcalfe, J.S., Miles, I.D. (eds.), Kluwer Academic Publishers, Boston-Dordrecht-London.

Tether, B.S., Hipp, Ch. [2002], Knowledge Intensive, Technical and Other Services: Patterns of Competitiveness and Innovation Compared, "Technology Analysis and Strategic Management", Vol. 14(2), pp. 163-182.

UNCTAD [2004], World investment report 2004: The shift towards services, United Nations Publications, New York-Geneva.

United Nations [2019], World Investment Report 2019. Special Economic Zones, United Nations Publications, New York.

Windrum, P., Tomlinson, M. [1999], Knowledge-intensive services and international competitiveness: A four-country comparison, "Technology Analysis and Strategic Management”, Vol. 11(3), pp. 391-408.

World Bank [2018], Global Investment Competitiveness Report 2017/2018: Foreign Investor Perspectives and Policy Implications, World Bank Group, Washington. 

Chapter 2

\title{
Changes in the EU Legal Framework on the Provision of Services in the Internal Market in the Past Decade ${ }^{1}$
}

\author{
Alina Szypulewska-Porczyńska
}

\subsection{Outline of the Problem and Literature Review}

2020 is a good time to reflect on the changes to the legal framework for the provision of services in the EU internal market. Firstly, ten years have already passed since the implementation of EU legislation with the greatest scope to date as regards the integration of service markets in the EU, namely Directive 2006/123/EC, known as the "Services Directive". Secondly, by 2019, other EU acts were to be implemented to improve and complement its functioning. In this chapter, the author has tried to assess the changes to the legal framework for the provision of services in the EU internal market over the last decade. Following a review of the literature and an outline of the main principles for the functioning of the internal market for services introduced by the Services Directive, the subsequent parts of the study present an analysis of proposals and major changes in the legal framework relating to the internal market in services, resulting from the implementation of the existing EU internal market strategy. Due to the subject matter under consideration, the study was based on a critical analysis of the source materials, i.e. EU documents, in particular legal acts.

The internal market for services has remained in focus of keen interest among researchers over the last dozen or so years due to changes in the EU legal framework The main theme of the analysis was the potential inherent in the integration of service markets, untapped due to constraints which generally constituted a parallel strand of scientific considerations. The studies published in the last dozen or so years in both the international and Polish literature, examining the problems related to the functioning of services in the EU internal market, focused on the implementation of the 2000

\footnotetext{
1 In practice, only $8 \mathrm{EU}$ member states have met the deadline. Greece was last to implement the Services Directive, in May 2012 [European Court of Auditors, 2016].
} 
Lisbon Strategy in the service sector, and more specifically on the Services Directive proposed by the European Commission in 2004. Many of these studies, published before the adoption of the legislation now in use, concerned the macroeconomic impact of the implementation of the directive. The first assessments of the removal of barriers were contained in publications by Kox, Lejour and Montizaan [2004] and Copenhagen Economics [2005]. The first comment on the effects of the implementation of the directive appeared in 2012 [Monteagudo, Rutkowski and Lorenzani 2012]. However, both previous analyses [e.g., Monteagudo et al., 2012], and later studies [IMF, 2014; Sunesen and Thelle, 2018] did not address the actual effects of the implementation of the directive, but they merely provided forecasts. Another group of analyses concerned the measures taken to integrate services markets in the EU [e.g., Szypulewska-Porczyńska, 2012]. The implementation of the 2015 strategy on upgrading the Single Market was accompanied by a smaller response. In Polish literature, the problem of assumptions and the nature of new EU initiatives following the Services Directive was examined by Stefaniak [2016].

In the context of the main problem addressed in the presented study, Kawka's analysis [Kawka, 2016] of the methods of integrating national legal systems in order to create a European single market for services deserves particular attention. The author raises the issue of a new approach to EU governance, which, as noted, in particular, after de Búrca and Scott [2006], consists in a more lenient, flexible and less hierarchical regulation, which takes into account the application of soft law, informal networks of member states' authorities, electronic databases and information exchange systems, and the peer review procedure for national arrangements [Kawka, 2016]. In the foreign literature, the problem of a new approach to governance in the European Union was reflected shortly after the Commission published a White Paper on this subject [European Commission, 2001] ${ }^{2}$. An example is the publication by Héritier [2002] under the notable title New Modes of Governance in Europe: Policy Making without Legislating?. According to V. Hatzopoulos, "new governance" is, following the EU's traditional "harmonization" and a new approach involving "mutual recognition", the third generation of methods for regulating the internal market [2012]. All previously applied arrangements are still present in the EU [cf. Szypulewska-Porczyńska, 2012]. The analysis presented in this chapter is an attempt to evaluate the eponymous changes compared to this recent trend of research.

2 The need to change the European governance system was notified by the European Commission five years before the Services Directive entered into force. 


\subsection{Main Principles of the Internal Market in Services in the Light of Directive 2006/123/EC}

For ten years, Directive 2006/123/EC has been the main piece of secondary legislation establishing a horizontal framework for the provision of services in the EU. Until its implementation on 28 December 2009, free movement of services, a fundamental freedom in the EU internal market, was mainly implemented on the basis of the resolution of disputes before the Court of Justice and regulations of an industry-specific nature. Directive 2006/123/EC did not replace previous legal arrangements. Previously regulated service industries, such as financial services, transport, or electronic communications, have been excluded from its scope. Complementing the EU legal order, Directive 2006/123/EC was the first legal act of a general nature relating to services in the internal market.

The Directive did not promote the application of the principle of mutual recognition, thus leaving member states a great deal of freedom to regulate the conditions of provision of services in their territory by other EU countries. That freedom is limited by two types of provisions of the directive. Firstly, the EU services market was liberalized by prohibiting the use by member states of 16 specific restrictions. Secondly, the requirements applied by EU countries to service providers have been harmonized.

A detailed description of prohibited requirements is provided in Table 2.1. An analysis of the information contained in the table shows that 8 restrictions relate to freedom of establishment (Article 14) and the same number to the freedom to provide services (Article 16(2) and Article 19), with only 2 of the prohibited requirements (7 and 8) applying also to recipients of services.

Table 2.1. Requirements prohibited in the EU internal market for services under Directive 2006/123/EC

\begin{tabular}{|l|l|}
\hline \multicolumn{1}{|c|}{ Type of freedom } & \multicolumn{1}{c|}{ Description of restriction } \\
\hline $\begin{array}{l}\text { Freedom of } \\
\text { establishment } \\
\text { a) service provider }\end{array}$ & $\begin{array}{l}\text { 1) discriminatory requirement based on nationality of the location of the } \\
\text { registered office } \\
\text { prohibition on having an establishment in more than one member state } \\
\text { 3) restriction on the freedom to choose between a principal or a secondary } \\
\text { establishment } \\
\text { 4) reciprocity with the member state in which the provider already has an } \\
\text { establishment } \\
\text { 5) application of an economic test for an economic purpose } \\
\text { 6) involvement of competing operators in decision-making } \\
\text { 7) requirement to provide insurance or financial guarantee from an institution } \\
\text { established in a particular member state } \\
\text { 8) requirement to have been pre-registered for a given period or to have } \\
\text { previously exercised the activity concerned }\end{array}$ \\
\hline
\end{tabular}


cont. tab. 2.1

\begin{tabular}{|l|l|}
\hline \multicolumn{1}{|c|}{ Type of freedom } & \multicolumn{1}{c|}{ Description of restriction } \\
\hline $\begin{array}{l}\text { Freedom } \\
\text { to provide } \\
\text { services }\end{array}$ & $\begin{array}{l}\text { 1) requirement to have an establishment } \\
\text { a) service provider requirement to obtain an authorization }\end{array}$ \\
& $\begin{array}{l}\text { 3) ban on setting up needed infrastructure } \\
\text { 4) requirement to apply specific contractual arrangements with the } \\
\text { service recipient which restrict service provision by the self-employed } \\
\text { 5) requirement to possess an identity document specific to the exercise } \\
\text { of a service activity }\end{array}$ \\
& $\begin{array}{l}\text { 6) requirements restricting the use of equipment and material which are an } \\
\text { integral part of the service provided, except for those necessary for health and } \\
\text { safety at work; }\end{array}$ \\
b) service recipient & $\begin{array}{l}\text { 1) requirement to obtain authorization or to make a declaration } \\
\text { 2) restriction of financial assistance on grounds of the place at which the service } \\
\text { is provided or the service provider's place of establishment }\end{array}$ \\
\hline
\end{tabular}

Source: Own study based on Directive 2006/123/EC of the European Parliament and of the Council of 12 December 2006 on services in the internal market (OJ L 376).

The harmonization of requirements adopted in Directive 2006/123/EC is evolutionary in nature and consists primarily in the commitment of EU member states to apply the three basic principles in regulating the provision of services in their territory. These are non-discrimination, necessity and proportionality. According to the provisions of the directive, those principles should be construed in the light of their interpretation by the Court of Justice. In simple terms, the principle of non-discrimination therefore means that a state,, when applying restrictions on the movement of services in the internal market, cannot rely on circumstances such as the location of the registered office of the undertaking, the place of establishment, nationality, residence, etc. The requirement imposed on a service provider or recipient in the internal market fulfils the condition of necessity if it is justified by an overriding reason relating to the public interest, public security, public health or environmental protection. It should also be noted that national requirements should take the least restrictive form in order to comply with the principle of proportionality, i.e. being suitable for achieving the objective pursued, they must not go beyond what is necessary to achieve it. In 2018, these principles were reflected in Directive (EU) 2018/958, which is presented below.

The European Commission oversees compliance with the above-mentioned principles by EU member states. Its tasks are shown in Figure 2.1.

It is clear from the above analysis (Figure 2.1) of the procedure for supervising compliance with the internal market principles with regard to national requirements restricting the flow of services that the Commission's competences fall within the framework of the traditional separation of powers within the European Union. Its tasks include supervising compliance with the law. Where a member state finds that EU law has been breached by a member state, the Commission may make appropriate 
recommendations to its authorities. The decision on whether infringement of the law continues and the imposition of more restrictive measures in the form of a financial penalty falls within the competence of the Court of Justice. It is difficult for EU institutions to enforce the principles of free movement of services within the internal market. First, this is due to the EU principles themselves which member states should apply in regulating the provision of services in their own territory. The provisions of the directive regarding the principle of necessity or proportionality will allow member states a great deal of discretion in interpreting them. Secondly, the effectiveness of the solution in the form of the infringement procedure against a member state that fails to comply with its obligations is limited in view of the long time needed by the Court to take a decision and enforce the judgment. In Poland, as in the EU on average, in 2017-2018, the time taken by a state to rectify an infringement was more than five years [European Commission, 2019b].

Figure 2.1. Schematic representation of supervision of compliance with the internal market principles with regard to national barriers restricting the flow of services introduced by Directive 2006/123/EC

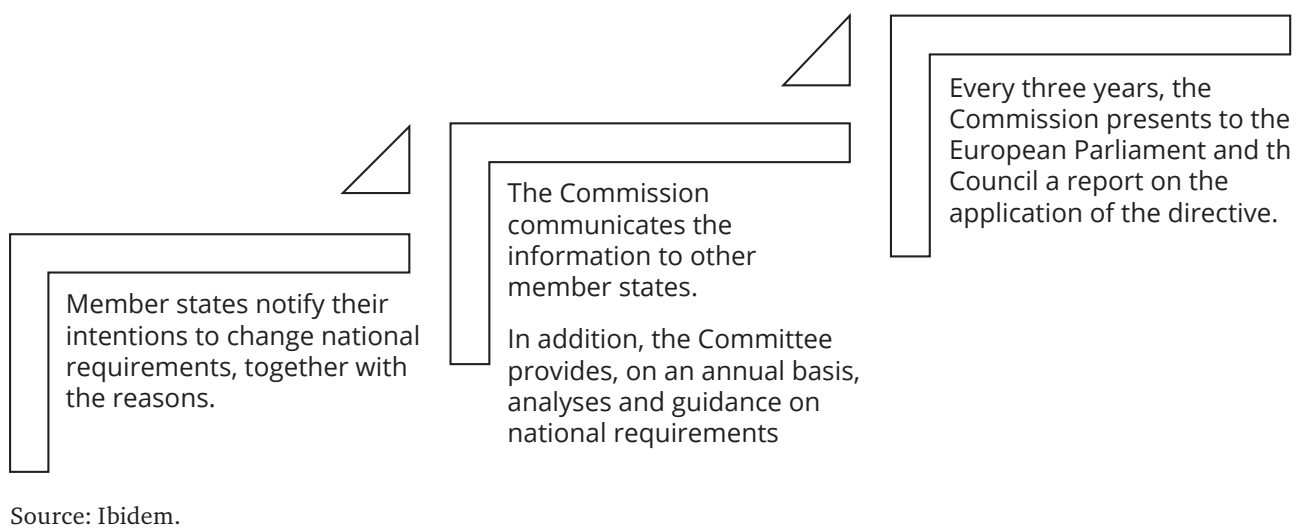

As the directive also includes national regulations that are at the draft stage, it should not only enable the enforcement of EU law by means of recommendations or judicial proceedings launched, but it should also primarily have a preventive function. Notification by Member States of draft national legislation can be seen as a restriction on their freedom to legislate on services.

The participation of the EU institutions with legislative competence, i.e. the Council and Parliament, as foreseen in the supervisory procedure, indicates that law-making in this area at EU level cannot be considered as a completed process. 


\subsection{Improving the Functioning of the Internal Market for Services in the Light of the Commission's 2015 Strategy}

New legislation could be expected, among other things, with regard to the procedure for supervising national requirements itself. In the strategy on upgrading the single market published by the Commission in October 2015 [European Commission, 2015], one of the proposals was to amend the notification procedure for new or revised national requirements for service providers or recipients (Table 2.2). It was modelled on the notification procedures for information society goods and services introduced by Directive (EU) 2015/1535. According to it, a requirement which a state has not notified is regarded as invalid and, consequently, suspended.

Table 2.2. Main actions planned by the Commission with regard to services in the 2015 strategy on upgrading the single market

\begin{tabular}{|l|l|l|}
\hline \multicolumn{1}{|c|}{ Domain/industry } & $\begin{array}{l}\text { Characteristics of existing } \\
\text { barrier }\end{array}$ & \multicolumn{1}{c|}{ Planned actions } \\
\hline $\begin{array}{l}\text { Access to and exercise } \\
\text { of regulated professions }\end{array}$ & $\begin{array}{l}\text { disproportionate } \\
\text { requirements and highly } \\
\text { divergent stringency of } \\
\text { national regulation }\end{array}$ & $\begin{array}{l}\text { - definition of a methodology for proportionality } \\
\text { assessment } \\
\text { issuing guidance to EU member states within } \\
\text { the European Semester } \\
\text { - introduction of a passport of compliance with } \\
\text { requirements in the home member state }\end{array}$ \\
\hline $\begin{array}{l}\text { Establishment and } \\
\text { operation of retail } \\
\text { business }\end{array}$ & $\begin{array}{l}\text { disproportionate and } \\
\text { inappropriate national } \\
\text { laws }\end{array}$ & $\begin{array}{l}\text { - identification of best practices in the EU and } \\
\text { development of guidelines for member states }\end{array}$ \\
\hline $\begin{array}{l}\text { E-commerce and other } \\
\text { forms of cross-border } \\
\text { shopping }\end{array}$ & $\begin{array}{l}\text { use of market } \\
\text { fragmentation strategies } \\
\text { on a territorial basis by } \\
\text { enterprises }\end{array}$ & $\begin{array}{l}\text { - introduction of rules prohibiting geo-blocking } \\
\text { amendment of regulation on cooperation } \\
\text { between states in consumer protection }\end{array}$ \\
\hline $\begin{array}{l}\text { Notification procedure } \\
\text { established by Directive } \\
2006 / 123 / \text { EC }\end{array}$ & $\begin{array}{l}\text { no notifications, } \\
\text { unclear notifications or } \\
\text { notifications made late } \\
\text { - at the final law stage }\end{array}$ & $\begin{array}{l}\text { - legislative proposal copying the notification } \\
\text { arrangements adopted in Directive (EU) } \\
\text { 2015/1535, covering information society } \\
\text { services }\end{array}$ \\
\hline
\end{tabular}

Source: Own study based on: European Commission [2015], Communication from the Commission to the European Parliament, the Council, the European Economic and Social Committee and the Committee of the Regions: Upgrading the Single Market: more opportunities for people and business, COM(2015) 550 final.

In addition to the horizontal action described above, the 2015 work plan to improve the functioning of the single market for services covered three selected service market sectors (Table 2.2). The most advanced proposals concerned regulated professions, i.e. those to which access requires a diploma, passing an examination or registering with a professional organization. The reform plan provided for two main types of 
changes in the form of the use of a common analytical framework for the review of existing and planned national regulations and the introduction of harmonized forms submitted by service providers to host countries. As a result, cross-border provision of services, including through posted workers, should become easier. As key to the development of the economy, the Commission has also identified service industries such as retail, e-commerce, construction, business services, and announced legislative action to remove regulatory barriers.

\subsection{Major Changes to the Legal Framework for the Internal Market in Services Resulting from the Implementation of the 2015 Strategy}

Not all of the Commission's plans contained in the 2015 strategy have been implemented (Table 2.3). Some of them have entered into force in a stripped-down form, others are awaiting further consideration, while still others have been rejected by the legislative institutions. As the first, and least problematic, draft legal act implementing the action foreseen in the 2015 strategy in the service sector, the Commission has submitted a proposal for a regulation of the European Parliament and of the Council on geo-blocking. Adopted after two years, i.e. in 2018, Regulation 2018/302 refers to barriers introduced by traders in the internal market, limiting access to their online interfaces or unjustifiably applying different general conditions of access to goods and services that hinder or prevent cross-border transactions by customers from other member states. Protection against discriminatory practices was provided both to consumers and to undertakings, but in the case of the latter the regulation covered purchases for end use only. Regulation 2018/302 identified situations in which geo-blocking is unjustified. And so, for example, a trader may not restrict access to their online interface for reasons related to a customer's nationality, place of residence or place of establishment, or redirect that customer to a different version of the interface without the customer's consent ${ }^{3}$.

In early 2017, the Commission presented further legislative proposals regulating three service areas. The Commission's proposals concerned a notification procedure for authorization systems and requirements for services, an analysis of proportionality before the adoption of new regulations on professions and the introduction of a European services e-card. In addition, in 2018, in its Communication to the European Parliament, the Council, the European Economic and Social Committee and the

3 Article 3(1) and (2) of Regulation (EU) 2018/302 of the European Parliament and of the Council. 
Committee of the Regions on the European retail sector, the Commission provided legal guidelines and best practices to help member states assess their legal framework and introduce less restrictive measures.

Table 2.3. Implementation of actions related to services, planned by the Commission in the 2015 strategy, as at Q3 2019.

\begin{tabular}{|c|c|c|c|}
\hline Domain/industry & Document & Implementation stage & Main provisions \\
\hline \multirow[t]{2}{*}{$\begin{array}{l}\text { Exercise and } \\
\text { access to regulated } \\
\text { professions }\end{array}$} & $\begin{array}{l}\text { directive on } \\
\text { a proportionality test } \\
\text { before adoption of } \\
\text { new regulation of } \\
\text { professions }\end{array}$ & $\begin{array}{l}\text { act adopted in June } \\
2018\end{array}$ & $\begin{array}{l}\text { - definition of } \\
\text { a methodology } \\
\text { for proportionality } \\
\text { assessment }\end{array}$ \\
\hline & $\begin{array}{l}\text { regulation } \\
\text { introducing } \\
\text { a European services } \\
\text { e-card and related } \\
\text { administrative facilities }\end{array}$ & $\begin{array}{l}\text { procedure stopped } \\
\text { in the Council at first } \\
\text { reading; regulation } \\
\text { proposal was } \\
\text { not supported by } \\
\text { the parliamentary } \\
\text { committee }\end{array}$ & $\begin{array}{l}\text { - introduction of a passport } \\
\text { of compliance with } \\
\text { requirements in the home } \\
\text { member state }\end{array}$ \\
\hline $\begin{array}{l}\text { Establishment and } \\
\text { operation of retail } \\
\text { business }\end{array}$ & $\begin{array}{l}\text { Commission } \\
\text { communication }\end{array}$ & published in April 2018 & $\begin{array}{l}\text { - identification of best } \\
\text { practices in the EU and } \\
\text { development of guidelines } \\
\text { for EU member states }\end{array}$ \\
\hline $\begin{array}{l}\text { E-commerce and } \\
\text { other forms of cross- } \\
\text {-border shopping }\end{array}$ & $\begin{array}{l}\text { regulation on } \\
\text { unjustified } \\
\text { geo-blocking }\end{array}$ & $\begin{array}{l}\text { act adopted } \\
\text { in February } 2018\end{array}$ & $\begin{array}{l}\text { - introduction of rules } \\
\text { prohibiting geo-blocking }\end{array}$ \\
\hline $\begin{array}{l}\text { Notification } \\
\text { procedure } \\
\text { established by } \\
\text { Directive 2006/123/ } \\
\text { EC }\end{array}$ & $\begin{array}{l}\text { directive on the } \\
\text { enforcement of } \\
\text { Directive } 2006 / 123 / E C\end{array}$ & $\begin{array}{l}\text { proposal pending first } \\
\text { reading }\end{array}$ & $\begin{array}{l}\text { - unconditional obligation } \\
\text { to notify } 3 \text { months before } \\
\text { introduction } \\
\text { - suspension of } \\
\text { requirement for } 3 \text { months } \\
\text { in case a warning is issued } \\
\text { by the Commission } \\
\text { - possibility of the } \\
\text { Commission issuing } \\
\text { a legally binding decision } \\
\text { requesting a member } \\
\text { state to refrain from } \\
\text { adopting or abolishing } \\
\text { requirements }\end{array}$ \\
\hline
\end{tabular}

Source: Own study based on: Proposal for a Directive of the European Parliament and of the Council on the legal and operational framework of the European services e-card introduced by ESC Regulation, COM(2016) 823 final; Proposal for a Regulation of the European Parliament and of the Council introducing a European services e-card and related administrative facilities, COM(2016) 824 final; Proposal for a Directive of the European Parliament and of the Council on the enforcement of the Directive 2006/123/EC on services in the internal market, laying down a notification procedure for authorisation schemes and requirements related to services, and amending Directive 2006/123/EC and Regulation (EU) No 1024/2012 on administrative cooperation through the Internal Market Information System, COM(2016) 821 final; Regulation (EU) 2018/302 of the European Parliament and of the Council of 28 February 2018 on addressing unjustified geo-blocking and other forms of discrimination based on customers' nationality, place of residence or place of establishment within the internal market and amending Regulations (EC) No 2006/2004 and (EU) 2017/2394 and Directive 2009/22/EC (OJ L 60); Directive (EU) 2018/958 of the European Parliament and of the Council of 28 June 2018 on a proportionality test before adoption of new regulation of professions (OJ L 173). 
Only one proposal from this "service package" has so far been implemented into EU law. It was Directive (EU) 2018/958 adopted in 2018, which established the main criteria that a state should consider when assessing the proportionality of requirements restricting access to or the pursuit of regulated professions ${ }^{4}$. They included the nature of the risks associated with the achievement of public interest objectives, the possibility of applying less restrictive measures, the link between the qualifications required and the activity pursued, the effects of the implementation of a particular measure ${ }^{5}$. Directive (EU) 2018/958 also clarifies the principle of necessity. The catalogue of overriding public interest objectives justifying the regulation of access to or the pursuit of professions, contained in that Directive, includes aspects such as "preserving the financial equilibrium of the social security system; the protection of consumers, of recipients of services [...], and of workers; the safeguarding of the proper administration of justice; ensuring the fairness of trade transactions; the combating of fraud and the prevention of tax evasion and avoidance, and the safeguarding of the effectiveness of fiscal supervision; transport safety; the protection of the environment and the urban environment; the health of animals; intellectual property; the safeguarding and conservation of the national historic and artistic heritage; social policy objectives; and cultural policy objectives"'.

As recently as Q3 2019, more than two years after the submission of the Commission proposal, a debate was in progress as part of the trialogue procedure on a draft Directive of the Parliament and of the Council laying down the notification procedure established by Directive 2006/123/EC. In particular, the Commission's proposal introduced the obligation to notify draft legislation, extended it to other regulatory requirements not covered by the notification procedure under the Services Directive (e.g. professional liability insurance, restrictions on multidisciplinary activities), and empowered the Commission to decide whether a national measure is compatible with the provisions of the Services Directive, and increased the severity of the consequences of non-compliance with the obligations under the Services Directive.

The proposal to strengthen measures enforcing compliance with the Services Directive was met with criticism from the European Economic and Social Committee (EESC), which considered an approach based on the consultation and implementation of best practices to be more effective under condition of political crisis in some member states [EESC, 2017]. The EESC stated that the proposal for a notification

4 The full title of this act is: Directive (EU) 2018/958 of the European Parliament and of the Council of 28 June 2018 on a proportionality test before adoption of new regulation of professions (OJ L 173/25-L 173/34).

5 Article 7 of Directive (EU) 2018/958.

6 Article 6 of Directive (EU) 2018/958. 
procedure did not guarantee a fair balance between economic freedoms under the Services Directive on one side and workers' rights and consumers' protection provided for in EU primary law, in particular in the Charter of Fundamental Rights. In the EESC's view, broadening the scope of the notification procedure and enforcement measures, as well as the complexity of the proposal would restrict the national legislator's freedom. The EESC claimed that negative decisions regarding the compliance of draft national laws and regulations should not be binding. Instead, the Committee suggested a positive approach in form of the award of a "compliance guarantee" for draft national measures. It is worth adding that the Commission's proposal also received a negative opinion from some national parliaments, including France and Germany, accusing the proposal of violating the principles of subsidiarity and proportionality [European Parliament, 2016].

At first reading in Parliament, the Committee on the Internal Market and Consumer Protection tabled amendments limiting the scope of the notification obligation and the minimum notification time, and introducing exceptions [European Parliament, 2016a]. Having regard to the term of office of the European Parliament and of the Commission ending in 2019, the trialogue discussions will continue in other compositions of these EU institutions. In February 2019, the Commission was against a compromise proposed by the Council.

The negative outcome of the vote in the same parliamentary committee prevented the adoption of the proposed regulation to promote a solution which, like the European Professional Card adopted in 2015 for five regulated professions ${ }^{7}$, would make it easier and faster for a service provider from another member state to confirm compliance with standards in the host country ${ }^{8}$. The proposal for a EU directive accompanying this regulation has also remained at the first reading stage in the Council. The arrangement was called the "European services e-card". Like the European Professional Card, the e-card was intended to be voluntary and to allow a wider inclusion of the country of origin in the procedure for the recognition of professional qualifications. The committee's proposal provided for the issuance of the services e-card for both cross-border activities and the setting up of a secondary establishment (branch, agency, office) ${ }^{9}$. In its resolution on the Single Market Strategy adopted in 2016, the European Parliament highlighted three aspects related to the use of this tool. In Parliament's view, there is a need, firstly, to adapt the passport to existing tools in the

\footnotetext{
7 For more on this subject, see Szypulewska-Porczyńska, A. [2017].

8 For details, see Proposal for a Regulation of the European Parliament and of the Council introducing a European services e-card and related administrative facilities, COM(2016) 824 final.

9 For details, see Proposal for a Directive of the European Parliament and of the Council on the legal and operational framework of the European services e-card introduced by ESC Regulation, COM(2016) 823 final.
} 
internal market such as the information exchange system and one-stop shops; secondly, to take into account the rules restricting treaty freedoms on grounds of overriding public interest, which are permissible under the case-law of the Court of Justice. Thirdly, Parliament opposed the introduction of the country of origin principle [European Parliament, 2016b]. The last issue was also raised later by the EU's advisory bodies of legislative institutions and lobbying groups such as the European Construction Industry Federation and the European Trade Union Confederation. According to critics of the e-card, the proposed amendments would lead to the application of the country of origin rule, i.e., a restriction of the competence of the host state. In their view, it is the host state that should be fully responsible for the procedure for monitoring national requirements. In its opinion, the EESC also referred to the EU legislative review of the Posting of Workers Directive by the EU legislative institutions, calling for the introduction of the principle of "equal pay for the same work in the same workplace" [European Economic and Social Committee, 2017]. This principle referred directly to the issue of the so-called social dumping, raised two years earlier (in 2016) by the European Parliament in its resolution [European Parliament, 2017].

The implementation of the single market strategy for services also covered other horizontal actions, such as the adoption, in December 2018, of a regulation on cooperation between national authorities responsible for the enforcement of consumer protection laws ${ }^{10}$ or the transmission of guidance to EU countries as part of the European Semester.

\subsection{Conclusions}

An analysis of the main changes to the EU legal framework for the provision of services in the internal market, introduced over the last decade, shows that there has been a shift from "hard" tools for regulating the internal market for services to the application of "soft" law. This falls in line with the concept of "new European governance". As a result, a more evolutionary nature of the integration of national service markets is to be expected rather than a significant improvement in the implementation of treaty freedoms in the field of trade in services. The resistance to the application of the principle of mutual recognition in the internal market for services, which accompanied the adoption of Directive 2006/123/EC, was also evident in the implementation of a later strategy to improve the application of that Directive. The "softening" of

\footnotetext{
10 For details, see Regulation (EU) 2017/2394 of the European Parliament and of the Council of 12 December 2017 on cooperation between national authorities responsible for the enforcement of consumer protection laws and repealing Regulation (EC) No 2006/2004 (OJ L 345), pp. 1-26.
} 
the instruments for development of the internal market for services is accompanied by the adoption of rules restricting competition in that market, such as arrangements adopted in the EU to prevent the so-called social dumping, i.e. "unfair competition" from member states with relatively low wages and social security for workers. The UK's exit from the EU is expected to exacerbate this trend. In the long term, the strengthening of the EU's social policy could lead to a deepening of economic integration.

\section{Bibliography}

Arentz, O., Hages, L., Recker, C. [2018], Cross-border services trade and regulation-Evidence from the European architectural sector, "Otto-Wolff-Discussion Paper", No. -1/2018-Assessments and recommendations of EU institutions issued to Poland in 2011-2019 as part of the evaluation of the national reform programme, https://eur-lex.europa.eu (21-25.09.2019).

Copenhagen Economics [2005], Economic Assessment of the Barriers to the Internal Market for Services, final report, January.

de Búrca, G., Scott, J. [2006], New Governance, Law and Constitutionalism, in: Law and New Governance in the EU and the US, de Búrca, G., Scott, J. (eds.), Oxford, Portland, Oregon, pp. 1-12.

Directive (EU) 2018/958 of the European Parliament and of the Council of 28 June 2018 on a proportionality test before adoption of new regulation of professions (OJ L 173)

Directive 2006/123/EC of the European Parliament and of the Council of 12 December 2006 on services in the internal market (OJ L 376).

ETUC (2018), Services Ecard (Regulation + Directive) - vote in IMCO, Services Ecard (Regulation + Directive) - vote in IMCO, letter to members of the IMCO parliamentary committee, Brussels, http://www.uni-europa.org (5.10.2019).

European Commission [2001], European Governance, white paper, COM(2001) 428 final.

European Commission [2015], Communication from the Commission to the European Parliament, the Council, the European Economic and Social Committee and the Committee of the Regions: Upgrading the Single Market: more opportunities for people and business, $\operatorname{COM}(2015) 550$ final.

European Commission [2019a], Spring Package - European Semester 2019. Overview of policy areas covered in the country-specific recommendations 2019, ec.europa.eu (21.11.2019).

European Commission [2019b], Single Market Scoreboard - Infringements. Reporting period: 12/2017-12/2018, https://ec.europa.eu/internal_market/scoreboard/performance_by_ governance_tool/infringements/index_en.htm (25.09.2019).

European Committee of the Regions [2018], Opinion of the European Committee of the Regions - The services package: A services economy that works for Europeans (2018/C 054/15).

European Court of Auditors [2016], Has the Commission ensured effective implementation of the Services Directive?, Special Report No. 5/2016. 
European Parliament [2016a], Procedure file services in the internal market: notification procedure for authorisation schemes and requirements related to services, Legislative Observatory, 2016/0398 (COD), https://oeil.secure.europarl.europa.eu/oeil/popups/ ficheprocedure.do lang $=$ \&reference $=2016 / 0398$ (COD) $(25.09 .2019)$.

European Parliament [2016b], Resolution of the European Parliament of 26 May 2016 on the Single Market Strategy, 2015/2354 (INI), www.europarl.europa.eu (2.10.2019).

European Parliament [2017], Understanding social dumping in the European Union, Briefing, March, https://www.europarl.europa.eu/RegData/etudes/BRIE/2017/599353/EPRS_ BRI(2017)599353_EN.pdf (25.11.2019).

European Social and Economic Committee [2017], Opinion of the European Social and Economic Committee of 31.8.2017(OJ C 288), pp. 43-51.

FIEC [2018], The European services e-card sent into limbo, Construction Europe, https://www. fiec-ar.eu (5.10.2019).

Hatzopoulos, V. [2007], Legal Aspects in Establishing the Internal Market for services. College of Europe, European Legal Studies, Research Papers in Law, No. 6/2007, pp. 1-33.

Héritier, A. [2002], New Modes of Governance in Europe: Policy Making without Legislating?, "Reihe Politikwissenschaft. Political Science Series", No. 81, pp. 1-24.

Kawka, I. [2015], Metody tworzenia europejskiego jednolitego rynku ustug, "Rocznik Administracji Publicznej", No. 1, pp. 117-144.

Kox, H., Lejour, A., Montizaan, R. [2004], The free movement of services within the EU, CPB Netherlands Bureau for Economic Policy Analysis, No. 69, pp. 7-84.

Kuźniar, R. [2019], Porządek międzynarodowy: perspektywa ontologiczna, Wydawnictwo Naukowe Scholar, Warsaw.

Monteagudo, J., Rutkowski, A., Lorenzani, D. [2012], The economic impact of the Services Directive: A first assessment following implementation, European Commission, Economic Papers, No. 456/2012.

Proposal for a Directive of the European Parliament and of the Council on the enforcement of the Directive 2006/123/EC on services in the internal market, laying down a notification procedure for authorisation schemes and requirements related to services, and amending Directive 2006/123/EC and Regulation (EU) No 1024/2012 on administrative cooperation through the Internal Market Information System, COM(2016) 821 final.

Proposal for a Directive of the European Parliament and of the Council on the legal and operational framework of the European services e-card introduced by ESC Regulation, $\operatorname{COM}(2016) 823$ final.

Proposal for a Regulation of the European Parliament and of the Council introducing a European services e-card and related administrative facilities, $\operatorname{COM(2016)~} 824$ final.

Regulation (EU) 2017/2394 of the European Parliament and of the Council of 12 December 2017 on cooperation between national authorities responsible for the enforcement of consumer protection laws and repealing Regulation (EC) No 2006/2004(OJ L 345). 
Regulation (EU) 2018/302 of the European Parliament and of the Council of 28 February 2018 on addressing unjustified geo-blocking and other forms of discrimination based on customers' nationality, place of residence or place of establishment within the internal market and amending Regulations (EC) No 2006/2004 and (EU) 2017/2394 and Directive 2009/22/EC (OJ L 60).

Stefaniak, J. [2016], Usługi w nowej strategii rynku wewnętrznego, "Prace Naukowe Uniwersytetu Ekonomicznego we Wrocławiu”, No. 439, pp. 324-334.

Stefaniak, J., Ambroziak, A. [2017], "Pakiet usługowy" Komisji Europejskiej - remedium na bariery na unijnym rynku ustug?, "Prace Naukowe Uniwersytetu Ekonomicznego we Wrocławiu", No. 487, pp. 306-317.

Sunesen, E., Thelle, M. [2018], Making EU trade in services work for all, Copenhagen Economics, November.

Szypulewska-Porczyńska, A. [2012], Znaczenie zasady wzajemnego uznawania dla integracji rynków usług w Unii Europejskiej, "Gospodarka Narodowa”, No. 5-6, pp. 79-97.

Szypulewska-Porczyńska, A. [2017], Znaczenie europejskiej legitymacji zawodowej dla integracji rynków usług państw Unii Europejskiej, “Studia i Prace WNEiZ US”, Vol. 49(2), pp. 193-203. 
Part II

Competitiveness of the Polish Economy in 2010-2019, with a Particular Focus on the Service Sector 

Chapter 3

\title{
Development of the Polish Economy in 2010-2019 Compared with Other EU Countries and Selected Emerging Markets, with a Particular Focus on the Service Sector
}

\author{
Ryszard Rapacki, Mariusz Próchniak
}

\subsection{International Background - Development Tendencies in World Economy}

Before moving on to the principal part of our analysis aimed at a comparative assessment of Poland's economic performance in 2010-2019, we will first outline the most important developments in the global economy witnessed during the same period.

According to preliminary, still partly estimated data provided in Table 3.1, the global gross national product increased in 2019 by $2.3 \%$, i.e., slower than in 2016-2018, and slightly slower than the medium-term trend reported in 2010-2015.

The slowdown recorded in the global economy in 2019 was a cumulative effect of a lower economic growth rate in almost all the groups of countries listed in the table, including in particular developed economies (from 2.2\% in 2018 to 1.7\%), as well as in transition countries (from $2.7 \%$ to $1.9 \%$ ) and in developing economies (from $4.2 \%$ to $3.4 \%$, respectively). Only the growth rate of the least developed economies was slightly faster than in 2016-2018 (4.0\% to 4.9\%). The economic slowdown involved, among other countries, the euro area, the USA, and Japan.

Against this background, economic growth rates in Southeast Asia were relatively favorable, although also there a slowdown could be seen (from 5.7\% in 2018 to $4.8 \%$ in 2019 , including especially China (6.6\% to $6.1 \%)$ and India (6.8\% to $5.7 \%)$. Simultaneously, the only region which saw some improvement in the pace of economic growth was Africa (from $2.6 \%$ to $2.9 \%$ ). On the other hand, growth rates in Latin America practically meant economic recession and, in relative terms, a negative contribution to the global development dynamics last year. 
Table 3.1. Economic growth in the world in 2012-2019 (growth rate in \%)

\begin{tabular}{|l|c|c|c|c|c|}
\hline \multicolumn{1}{|c|}{ Years } & $\begin{array}{c}2012-2015 \\
\text { (annual average) }\end{array}$ & 2016 & 2017 & 2018 & $2019 *$ \\
\hline World** & $2.7 * * * *$ & 2.5 & 3.2 & 3.0 & 2.3 \\
\hline Developed economies & 1.6 & 1.7 & 2.4 & 2.2 & 1.7 \\
\hline Euro area & 0.6 & 1.9 & 2.5 & 1.9 & 1.2 \\
\hline USA & 2.4 & 1.6 & 2.4 & 2.9 & 2.2 \\
\hline Japan & 1.3 & 0.6 & 1.9 & 0.8 & 0.7 \\
\hline Transition economies & 1.3 & 0.8 & 2.2 & 2.7 & 1.9 \\
\hline Russia & 1.0 & 0.3 & 1.6 & 2.3 & 1.1 \\
\hline Developing economies of which: & 4.6 & 4.0 & 4.5 & 4.2 & 3.4 \\
\hline least developed countries & 4.9 & 4.0 & 4.5 & 4.6 & 4.9 \\
\hline Africa*** & 3.9 & 1.7 & 2.7 & 2.6 & 2.9 \\
\hline Southeast Asia & 6.0 & 6.1 & 6.1 & 5.7 & 4.8 \\
\hline China & 7.5 & 6.7 & 6.8 & 6.6 & 6.1 \\
\hline India & 6.8 & 8.2 & 7.2 & 6.8 & 5.7 \\
\hline Latin America & 1.7 & -1.1 & 1.2 & 0.9 & 0.1 \\
\hline
\end{tabular}

* Preliminary data. ** At 2010 market exchange rates *** Excluding Libya. **** 2013-2015.

Note: Growth rate for groups of countries has been calculated as the weighted average of GDP growth rates of individual countries. Weights derived from 2010 prices and rates of exchange.

Source: United Nations [2020].

\subsection{Size of the Polish Economy}

The analysis of the economic performance achieved by Poland in 2019 and its international competitive position will begin with the presentation of a brief assessment of the economic potential of our country against the background of the world economy, as well as Poland's position in this respect in the European Union' 1 .

The basic measure of the size of an economy is the value of the gross domestic product (GDP) generated in a given country in a particular year. Despite its many shortcomings and limitations, it is still the broadest measure of economic activity, widely used in macroeconomic analyses. In international data summaries, the GDP values of individual countries denominated in national currencies are converted into international currency (e.g. USD or EUR) using current market exchange rates (CERs) or conventional conversion factors called purchasing power parities (PPPs). The GDP

1 The content of this and successive sub-chapters refers to the earlier editions of the Report (see, e.g., Matkowski, Rapacki, Próchniak, 2016; Rapacki and Próchniak, 2019]. This edition includes an update of 2019 data. 
value calculated at PPP is believed to better reflect the real value of output produced in a given country, as it takes into account the differences in prices in goods and services markets between the country and abroad; it is also less susceptible to the impact of exchange rate fluctuations. For this reason, this metric is used more often in broad international comparisons. On the other hand, the currency converters used to calculate GDP at PPP are inaccurate and often inflate the value of GDP for less developed countries compared to its value in more developed countries (the same reservation applies to GDP per capita). In our assessments, the values of total GDP and GDP per capita will be provided based on both of these approaches: converted into international currency at CER and at PPP, so as to ensure more comprehensive comparisons.

According to the IMF's preliminary estimates [IMF, 2020], in 2019, Poland's GDP converted at CER amounted to USD $565.9 \mathrm{bn}$, whereas its value calculated at PPP was more than twice as high (USD 1,286.9 bn). In terms of GDP value at CER, Poland ranked $22^{\text {nd }}$ among the world's largest economies (between Taiwan and Thailand), and in terms of GDP value at PPP $-23^{\text {rd }}$ (between Taiwan and Nigeria), respectively. Compared with 2019, Poland's position in the CER-based global ranking of economies improved by one position owing to a relatively fast growth of its economy when benchmarked against other countries with a similar economic potential. Poland's share in the global value of output increased slightly, when measured at CER, to $0.7 \%$, whereas at PPP it did not change and still stood at $0.9 \%$. This indicator, reflecting Poland's position in the global economy, has remained relatively stable for many years, while the exact position of Poland in the world ranking of economies by GDP size changes every year due to cyclic fluctuations in output, changes in inflation rates and exchange rates, as well as adjustments of GDP data and currency conversion factors.

Let us now look at the data showing Poland's economic position in the European Union (EU-28). Table 4.3 presents data on the GDP value of the individual EU member states in 2019, expressed in EUR at current market exchange rates (CERs) and at purchasing power parity (PPP). All the GDP data for 2019 are based on preliminary estimates published by the European Commission in October 2019 [European Commission, 2019], which may be subject to change. The ranking of the EU member states' economies provided in the table has been drawn up in accordance with the CER-measured GDP value; the positions of individual countries in the alternative ranking based on the PPP-measured GDP value are shown in brackets.

The European Union in its previous composition (i.e., until the end of January 2020, when Brexit took place, consisted of 28 member states of highly diverse sizes and economic potential. The five largest countries in terms of population and production volume - Germany, the UK, France, Italy, and Spain - represented 63\% of the total population of the EU-28 countries and produced $69 \%$ of the total GDP at CER 
and $67 \%$ at PPP. The 15 countries forming the EU before its enlargement (EU-15) represented $80 \%$ of the total population and produced $91 \%$ of the total GDP at CER and 85\% at PPP. In contrast, the 13 new member states that joined the EU in 2004 and 2007 or later, i.e. 11 CEE countries, plus Cyprus and Malta, represented $20 \%$ of the total population but generated only $9 \%$ or $15 \%$, respectively, of the Community's total GDP. This huge asymmetry between the old EU and the new member states (more broadly, between Western Europe and Central and Eastern Europe) should be kept in mind when considering Poland's position in the European Union.

Table 3.2. EU28 member states according to GDP value in 2019 (in EUR bn)

\begin{tabular}{|c|c|c|c|c|c|}
\hline \multirow{2}{*}{ Rank } & \multirow{2}{*}{ Country } & \multicolumn{2}{|c|}{ GDP at CER } & \multicolumn{2}{|c|}{ GDP at PPP } \\
\hline & & EUR bn & $\%(E U-28=100)$ & EUR bn & $\%(E U-28=100)$ \\
\hline $1 \quad(1)$ & Germany & $3,427.0$ & 20.9 & $3,178.0$ & 19.4 \\
\hline $2 \quad(3)$ & United Kingdom & $2,506.0$ & 15.3 & $2,227.0$ & 13.6 \\
\hline $3 \quad(2)$ & France & $2,416.0$ & 14.7 & $2,212.0$ & 13.5 \\
\hline $4 \quad(4)$ & Italy & $1,777.0$ & 10.8 & $1,819.0$ & 11.1 \\
\hline $5 \quad(5)$ & Spain & $1,242.0$ & 7.6 & $1,359.0$ & 8.3 \\
\hline $6 \quad(7)$ & Netherlands & 806.5 & 4.9 & 709.7 & 4.3 \\
\hline $7 \quad(6)$ & Poland & 526.2 & 3.2 & 890.3 & 5.4 \\
\hline $8(10)$ & Belgium & 472.3 & 2.9 & 427.0 & 2.6 \\
\hline $9 \quad(8)$ & Sweden & 470.7 & 2.9 & 393.9 & 2.4 \\
\hline $10(11)$ & Austria & 398.9 & 2.4 & 358.2 & 2.2 \\
\hline 11 (13) & Ireland & 345.0 & 2.1 & 306.7 & 1.9 \\
\hline 12 (16) & Denmark & 308.2 & 1.9 & 234.3 & 1.4 \\
\hline $13(18)$ & Finland & 240.9 & 1.5 & 194.7 & 1.2 \\
\hline $14(12)$ & Romania & 222.4 & 1.4 & 411.1 & 2.5 \\
\hline $15 \quad(9)$ & Czech Republic & 218.0 & 1.3 & 311.3 & 1.9 \\
\hline $16(14)$ & Portugal & 210.8 & 1.3 & 251.8 & 1.5 \\
\hline 17 (15) & Greece & 189.5 & 1.2 & 232.3 & 1.4 \\
\hline 18 (17) & Hungary & 142.9 & 0.9 & 228.6 & 1.4 \\
\hline 19 (19) & Slovakia & 94.4 & 0.6 & 135.7 & 0.8 \\
\hline $20 \quad(24)$ & Luxembourg & 62.9 & 0.4 & 50.8 & 0.3 \\
\hline 21 (20) & Bulgaria & 60.7 & 0.4 & 116.7 & 0.7 \\
\hline $22(21)$ & Croatia & 54.0 & 0.3 & 83.3 & 0.5 \\
\hline 23 (23) & Lithuania & 48.7 & 0.3 & 73.9 & 0.5 \\
\hline $24 \quad(22)$ & Slovenia & 48.2 & 0.3 & 58.0 & 0.4 \\
\hline $25 \quad(25)$ & Latvia & 30.8 & 0.2 & 43.0 & 0.3 \\
\hline 26 (26) & Estonia & 27.8 & 0.2 & 35.3 & 0.2 \\
\hline
\end{tabular}




\begin{tabular}{|c|c|c|c|c|c|}
\hline \multirow{2}{*}{ Rank } & \multirow{2}{*}{ Country } & \multicolumn{2}{|c|}{ GDP at CER } & \multicolumn{2}{|c|}{ GDP at PPP } \\
\hline & & EUR bn & $\%(E U-28=100)$ & EUR bn & $\%(E U-28=100)$ \\
\hline $27 \quad(27)$ & Cyprus & 22.1 & 0.1 & 24.8 & 0.2 \\
\hline $28 \quad(28)$ & Malta & 13.2 & 0.1 & 15.5 & 0.1 \\
\hline & EU-28 & $16,383.0$ & 100.0 & $16,383.0$ & 100.0 \\
\hline & EU-15 & $14,873.0$ & 90.8 & $13,955.0$ & 85.2 \\
\hline
\end{tabular}

Note: The 2019 GDP data are the European Commission's preliminary estimates. The country's position shown in the first column corresponds to the value of GDP at CER and PPP (in brackets). Contributions to total EU-28 GDP have been calculated by the authors.

Source: European Commission [2019].

Poland is the largest country among the new member states of the European Union. This concerns both its territory and population, and GDP size. In the enlarged European Union (EU-28), Poland ranks $6^{\text {th }}$ in terms of territory and population $(7.1 \%$ and $7.5 \%$, respectively), as well as in terms of GDP at PPP (5.4\%), whereas the CER-measured GDP level puts Poland in $7^{\text {th }}$ place (3.2\%). As can be seen, Poland's contribution to the economic potential of the EU-28 is much lower than might be suggested by the size its territory and population. However, this should not come as a surprise in light of historical experience (a similar disparity is witnessed for all CEE countries).

It is worth noting that Poland's position in the European economy has improved significantly since joining the EU. Its contribution to the total GDP of all the current EU member states measured at CER increased from 1.9\% in 2004 to $2.8 \%$ in 2010 and $3.2 \%$ in 2019. Similarly, Poland's contribution to the total EU-28 GDP at PPP increased from $3.6 \%$ in 2004 to $4.7 \%$ in 2010 , and $5.4 \%$ in 2019.

\subsection{Economic Growth and Real Convergence}

The year 2019 saw, as did the whole global economy (see Table 3.1), a certain slowdown of economic activity in Poland. The GDP growth rate turned out to be $1 \mathrm{pp}$ lower than a year earlier; at the same time, it was nearly 1 pp higher than the average throughout the systemic transformation period. It was also one of the highest among the new EU member states from Central and Eastern Europe (CEE-11). This has not, however, fundamentally changed the existing development trends in either temporal or spatial terms. In 1990-2019, the average annual GDP growth rate in Poland was the highest in this group of countries and almost three times as high as a similar average rate in the "old" EU-15 countries. Similar trends were witnessed in the development trajectories of Poland and the two reference groups in 2004-2019, i.e., after Poland's accession to the EU. The situation changed slightly in this respect over the 2010-2019 
period under analysis in this year's Report. The differentials in development dynamics decreased significantly over that period, both within the CEE-11 group and between the CEE countries and the EU-15 average. During that time, Poland also lost its leader position to several other CEE-11 countries. The respective data is provided in Table 3.3.

Table 3.3. GDP growth in 1990-2019

\begin{tabular}{|c|c|c|c|c|c|c|c|}
\hline \multirow{3}{*}{ Country } & \multicolumn{4}{|c|}{ GDP growth rate (constant prices) } & \multirow{2}{*}{\multicolumn{3}{|c|}{ Real GDP level in 2019}} \\
\hline & \multirow{2}{*}{$\begin{array}{l}\text { average annual } \\
\text { growth rate in \% } \\
1990-2019\end{array}$} & \multicolumn{3}{|c|}{ annual growth rate in $\%$} & & & \\
\hline & & 2010 & 2018 & $2019 *$ & $1989=100$ & $2004=100$ & $2010=100$ \\
\hline Poland & 3.2 & 3.6 & 5.1 & 4.1 & 256 & 180 & 137 \\
\hline Bulgaria & 0.9 & 0.6 & 3.1 & 3.6 & 133 & 157 & 125 \\
\hline Croatia & 0.5 & -1.5 & 2.7 & 2.9 & 116 & 120 & 112 \\
\hline Czech Republic & 1.8 & 2.3 & 2.8 & 2.5 & 169 & 147 & 122 \\
\hline Estonia & 2.0 & 2.7 & 4.8 & 3.2 & 184 & 149 & 138 \\
\hline Lithuania & 1.1 & 1.5 & 3.6 & 3.8 & 137 & 158 & 138 \\
\hline Latvia & 0.9 & -4.5 & 4.6 & 2.5 & 132 & 146 & 135 \\
\hline Romania & 1.7 & -3.9 & 4.4 & 4.1 & 163 & 170 & 141 \\
\hline Slovakia & 2.5 & 5.7 & 4.0 & 2.7 & 207 & 173 & 128 \\
\hline Slovenia & 1.9 & 1.3 & 4.1 & 2.6 & 173 & 134 & 118 \\
\hline Hungary & 1.7 & 0.7 & 5.1 & 4.6 & 164 & 134 & 130 \\
\hline EU-15 ** & 1.3 & 2.2 & 1.8 & 1.2 & 149 & 120 & 113 \\
\hline
\end{tabular}

*Estimates. ** Weighted average.

Historical EBRD data referring to 1989 was also used to calculate the growth rates, based on $1989=100$.

Source: Eurostat [2020]; European Commission [2019]; own calculations.

In 1990-2019, Poland was the only country in the CEE group to have increased its real GDP level more than two and a half times (with an index of 256). This translates into an average annual growth rate (taking into account the 1990-1991 transformation recession) of 3.2\%. The only CEE-11 country with comparable growth dynamics was Slovakia (2.5\% annually).

After Poland's EU accession, its GDP increased by $80 \%$ (i.e., at an average annual rate of approx. 4.2\%). Just as throughout the systemic transformation period, Poland maintained its leader position among the new EU member states in this respect (a similar result was achieved by Slovakia at this time, at 73\% and Romania, at 70\%). At the same time, Poland significantly outpaced the EU-15 countries in terms of development dynamics.

Poland lost its position of economic growth leader in the CEE group during the period under analysis in this study (2010-2019); at the same time, its "growth 
comparative advantage" also decreased significantly relative to the EU-15 (the chain GDP growth indices in the period were 137 and 113, respectively, see Table 3.3). This was mainly a consequence of a significant slowdown in Poland's growth - the average annual GDP growth rate in those years was 3.2\%, i.e., 1 pp less than in 2004-2019, i.e. after the country's accession to the EU (4.2\%). It cannot be ruled out that the developments described here may be the first harbinger of the secular changes to the hitherto growth trajectories in the EU member states, mentioned in the previous editions of this Report, and of the deceleration or even reversal of the real convergence process of the Polish economy with the EU-15 countries [Matkowski, Rapacki and Próchniak, 2016b].

As a result of the combined impact of the trends presented above, Poland managed to significantly reduce its gap in economic development relative to all the existing EU member states (except for Ireland), as well as all CEE countries in 1990-2019. In this case, the changes in the relative developmental position of the Polish economy were not only a consequence of a faster rate of economic growth, but also a function of diverging demographic trends and diverse directions and pace of change in real exchange rates in individual countries.

The real convergence process in Poland was unfolding at the fastest rate in relation to the United Kingdom, Italy and Greece. In relation to the last-mentioned country, Poland completely closed the gap in 2015, and in the following years overtook it in terms of GDP per capita. This marked a historical precedent, as Poland outpaced one of the "old" EU member states in terms of economic development level. It is quite likely that this scenario may soon be repeated in relation to Portugal².

Within the CEE group of new member states, Poland has been the most successful in closing the distance between its level of economic development and that of the richest countries, i.e. Slovenia and the Czech Republic.

As shown in Table 3.4, in 2019 Poland's PPP-measured GDP per capita stood at 68\% of the EU-15 average ${ }^{3}$. This implies that between 1989 and 2019 Poland narrowed by 30 percentage points the development gap with the "old" Union, of which 25 points were gained after its EU entry (i.e. in 2004-2019). This shows, among other things, that the rate of real convergence accelerated markedly in Poland after joining the EU; while it

2 According to the IMF forecast of October 2019, GDP per capita at PPP in Poland was to reach USD 33,890 (in current prices), i.e. more than in Portugal (USD 33,665). By comparison, the corresponding values calculated in constant prices (2011 US dollars) were expected to be USD 29,587 and USD 29,291 [IMF, 2019]. A slightly different picture emerges from Eurostat data: in 2018, GDP per capita at PPP amounted to EUR 24,014 in Portugal vs. EUR 22,199 in Poland, which represented approx. 92\% of the level achieved in Portugal (development distance - 8\%). According to preliminary data, Poland's development gap relative to Portugal narrowed in 2019 by about 2 pp, i.e. to 6\% (own calculations based on Eurostat data).

3 It is worth noting, however, that, when converted at the (current) market exchange rate, Poland's GDP represented only 31\% of the EU-15 average in 2019 (arithmetical average; own calculations based on Eurostat data). 
stood at an average of $0.5 \mathrm{pp}$ in 1990-2003, it increased fourfold over the 2004-2019 period to almost 2 pp annually.

Table 3.4. Development gap in new EU member states in relation to EU-15 in 1989-2019 (GDP per capita at PPP, EU15 $=100$ )

\begin{tabular}{|l|c|c|c|c|c|}
\hline \multicolumn{1}{|c|}{ Country } & 1989 & 2004 & 2010 & 2018 & $2019 *$ \\
\hline Poland & $\mathbf{3 8}$ & $\mathbf{4 3}$ & $\mathbf{5 7}$ & $\mathbf{6 6}$ & $\mathbf{6 8}$ \\
\hline Bulgaria & 47 & 30 & 42 & 48 & 49 \\
\hline Croatia & 51 & 50 & 54 & 58 & 60 \\
\hline Czech Republic & 75 & 69 & 76 & 85 & 86 \\
\hline Estonia & 54 & 48 & 69 & 77 & 78 \\
\hline Lithuania & 55 & 44 & 67 & 75 & 78 \\
\hline Latvia & 52 & 41 & 57 & 65 & 66 \\
\hline Romania & 34 & 30 & 49 & 60 & 63 \\
\hline Slovakia & 59 & 50 & 69 & 72 & 73 \\
\hline Slovenia & 74 & 75 & 74 & 81 & 82 \\
\hline Hungary & 56 & 55 & 61 & 66 & 69 \\
\hline
\end{tabular}

* Estimates.

Source: IMF for 1989 [IMF, 2005]; Eurostat for 2004 and 2010; European Commission for 2018-2019 [European Commission, 2019]; own calculations.

When compared to the other new EU member states from CEE, Poland's results are relatively favorable, especially in terms of the entire systemic transformation period to date. In 1990-2019, Poland was a definite leader in the process of real convergence toward the EU-15 countries among the new EU member states. However, Poland lost this position after 2004. During the period following the enlargement of the Union, the real convergence process proceeded the fastest in Lithuania (34 pp), Romania (34 pp), and Estonia (30 pp). At the same time, Poland also saw a divergence process in relation to some CEE countries, as our development gap increased after 2004 relative to Estonia and Lithuania, while also Romania edged closer to Poland in terms of development level.

What is more, Poland's pace of catching up with more developed EU-15 countries clearly slowed down in 2011-2019. While Poland narrowed the development gap with the EU-15 by 14 pp during the first six years of its EU membership (2004-2010), over the following nine years the country's development gap decreased by only $11 \mathrm{pp}$. 


\subsection{Socio-Economic Development and the Standard of Living}

The basic indicator of the level of socio-economic development and standard of living is the gross domestic product per capita. Figure 3.1 shows the ranking of the EU-28 countries in terms of GDP per capita at PPP in 2004 and 2019. It allows the current level of real income in individual countries to be compared, as well as its growth since mid-1990s, that is, more or less, since the end of the transformation recession in most CEE countries. The ranking below also allows the GDP per capita growth rate since the major EU enlargement to be determined. The GDP per capita data for 2019 are preliminary estimates. For CEE countries, the values of GDP per capita (as well as the values of total GDP) at PPP are much higher than corresponding values calculated at CER.

According to estimated data published by the European Commission [European Commission, 2019] in 2019 the PPP-measured average GDP per capita in the enlarged EU (EU-28) amounted to EUR 31,832. In the euro area, in its present composition (EA-19), it was EUR 33,534, and in the pre-enlargement EU member states (EU-15) - EUR 33,994.

The levels of income are highly divergent across the EU member states. The leader in terms of GDP per capita is Luxembourg (EUR 81,656) ${ }^{4}$, with Ireland ranking second (EUR 62,375). The following countries also report high income per capita (EUR 32,000 to 41,000): the Netherlands, Austria, Denmark, Sweden, Germany, Belgium, Finland, the United Kingdom, and France. Malta, Italy, and Spain have slightly lower income per capita (between EUR 28,000 and 32,000). Less economically developed countries of Western Europe, such as Cyprus, Portugal and Greece, have much lower incomes (EUR 21,000-27,000). In Central and Eastern Europe, GDP per capita ranges between EUR 16,734 in Bulgaria and 29,178 in the Czech Republic.

Viewed against this background, Poland's position is not impressive. With the value of GDP per capita at PPP equal to EUR 23,184 in 2019, Poland ranked 22 $2^{\text {nd }}$, falling within the lower income bracket among the enlarged EU countries, ahead of Latvia, Greece, Romania, Croatia and Bulgaria.

4 The exceptionally high value of GDP per capita in Luxembourg does not accurately reflect the difference in the standard of living in that country in relation to other Western European countries; this results mainly from the high income earned by international corporations, banks and financial institutions headquartered in that country. 
Figure 3.1. Ranking of EU-28 countries in terms of GDP per capita at PPP (in EUR)

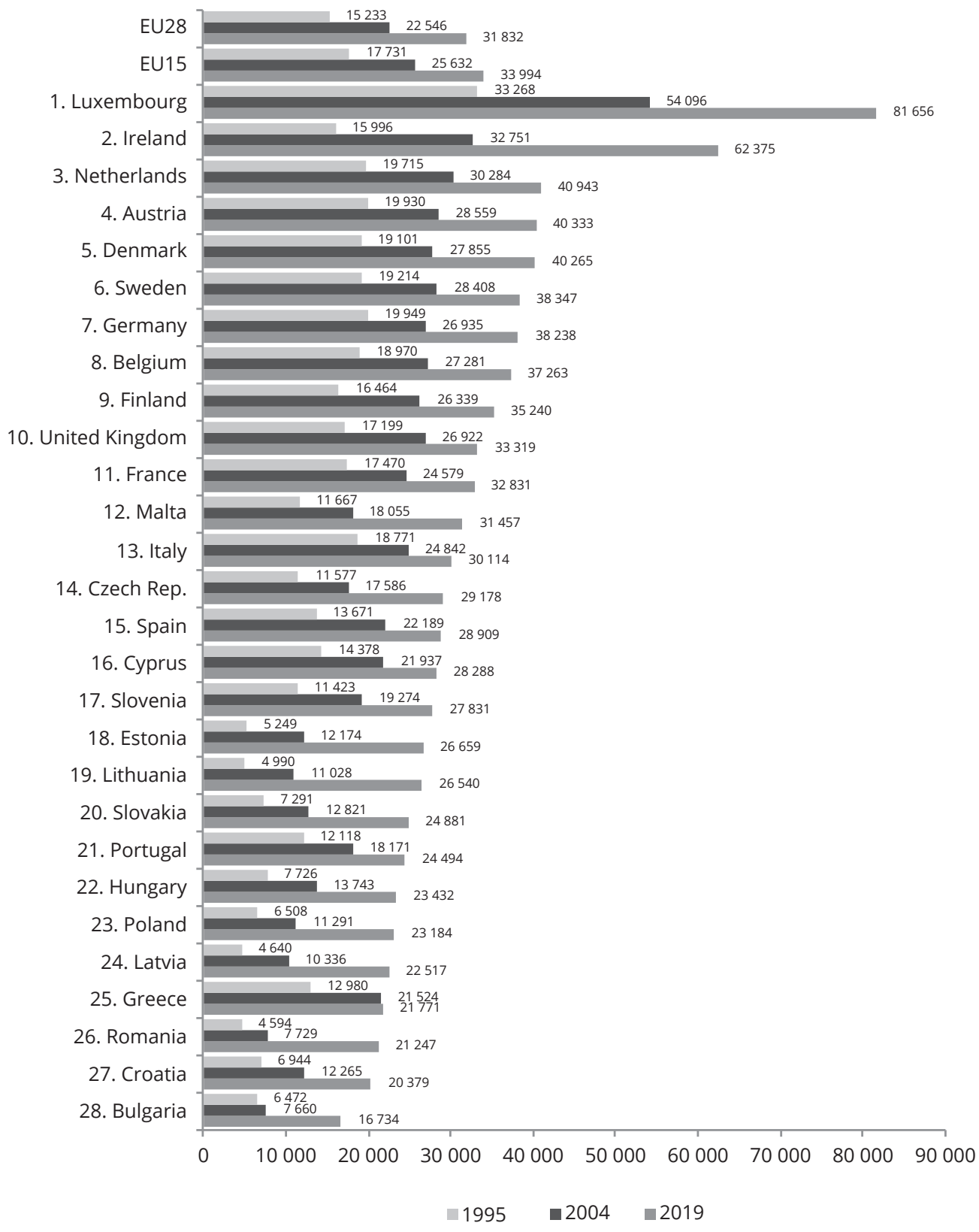

Note: The ranking has been drawn up in accordance with preliminary PPP-measured GDP data for 2019. The GDP per capita data has been calculated by dividing the total GDP by the total population (based on European Commission data). Source: Own compilation based on European Commission data [European Commission, 2019] 
Table 3.5 shows the level of economic development of different groups of countries in 2004-2019, measured by the value of GDP per capita at PPP. The table provides data on the European Union member states (EU-28), as well as selected other groups, classified mainly according to the geographical criterion. The data contained in Table 3.5 make it possible to find out whether the other groups of countries have moved closer to the EU over the past 15 years in terms of development level, or experienced divergence tendencies instead.

Among five groups of countries other than the EU, only two: the Commonwealth of Independent States (CIS) and Southeast Asia have markedly narrowed their development gap with the EU-28. The CIS group improved its relative level of economic development from 38\% of the EU-28 average in 2004 to 49\% in 2019 (i.e., by 11 pp), and the Asian group narrowed the gap from 14\% to 30\% (by 16 pp). The other three groups (Latin America, Middle East, and Africa) have narrowed the gap with the EU-28 in terms of relative development level by only $1 \mathrm{pp}$, have not reduced the income gap at all, which means no real convergence with the EU.

Table 3.5. The economic development level of the European Union compared with other groups in the world

\begin{tabular}{|c|c|c|c|c|c|c|}
\hline \multirow{2}{*}{ Group } & \multirow{2}{*}{$\begin{array}{l}\text { Number of } \\
\text { countries }\end{array}$} & \multicolumn{5}{|c|}{ GDP per capita at purchasing power parity } \\
\hline & & 2004 & 2010 & 2015 & 2018 & 2019 \\
\hline \multicolumn{7}{|c|}{ in international dollars (current prices) } \\
\hline European Union & 28 & 28,237 & 33,723 & 38,514 & 43,148 & 44,468 \\
\hline Commonwealth of Independent States & 12 & 10,850 & 15,904 & 18,871 & 20,827 & 21,576 \\
\hline Southeast Asia & 30 & 3,844 & 6,906 & 10,075 & 12,487 & 13,392 \\
\hline Latin America and Caribbean & 33 & 10,228 & 13,505 & 15,648 & 16,220 & 16,575 \\
\hline Middle East and North Africa & 21 & 12,050 & 15,298 & 17,676 & 18,821 & 19,002 \\
\hline sub-Saharan Africa & 45 & 2,414 & 3,280 & 3,929 & 4,112 & 4,221 \\
\hline \multicolumn{7}{|c|}{$E U-28=100$} \\
\hline European Union & 28 & 100.0 & 100.0 & 100.0 & 100.0 & 100.0 \\
\hline Commonwealth of Independent States & 12 & 38.4 & 47.2 & 49.0 & 48.3 & 48.5 \\
\hline Southeast Asia & 30 & 13.6 & 20.5 & 26.2 & 28.9 & 30.1 \\
\hline Latin America and Caribbean & 33 & 36.2 & 40.0 & 40.6 & 37.6 & 37.3 \\
\hline Middle East and North Africa & 21 & 42.7 & 45.4 & 45.9 & 43.6 & 42.7 \\
\hline sub-Saharan Africa & 45 & 8.5 & 9.7 & 10.2 & 9.5 & 9.5 \\
\hline
\end{tabular}

Source: Own compilation based on International Monetary Fund data [IMF, 2019].

The GDP per capita index used in the analysis presented is merely an approximate and indicative measure of living standards. Its value depends on many factors, 
not only economic ones. In the literature, there are a number of measures of the level of socio-economic development alternative to GDP per capita. One of them is the Human Development Index (HDI) published by the United Nations. It is the geometric mean of three indices expressing: Gross National Income (GNI) per capita, life expectancy, and education level; these, in turn are to reflect the three main tiers of social development: a long and healthy life, solid knowledge and a decent standard of living. The index ranges from 0 to 1 (higher values indicating a higher level of development).

According to the 2019 report [UNDP, 2019], referring to 2018 data, the global classification leaders in terms of HDI are: Norway, Switzerland, Ireland, Germany, Hongkong, Australia, Iceland, Sweden, Singapore, the Netherlands, Denmark, Finland, Canada, New Zealand, the United Kingdom, and the USA. Ranking highest among the CEE countries in this category is Slovenia (24), followed by: Czech Republic (26), Estonia (30), Poland (32), Lithuania (34), Slovakia (36), Latvia (39), Hungary (43), Croatia (46), Bulgaria and Romania (joint 52). In terms of the value of this indicator, Poland ranks slightly above the CEE average (the indicator value for Poland equals 0.872 against the average of 0.858 for 11 CEE countries), but it ranks only $32^{\text {nd }}$ in the world in this category, among 189 classified countries. Among the EU countries, Poland holds the $20^{\text {th }}$ position, ahead of Lithuania, Slovakia, Latvia, Portugal, Hungary, Croatia, Bulgaria, and Romania. The value of the HDI for Poland is steadily increasing, which testifies to the continuity of socio-economic development. However, its position in the global HDI ranking remains quite remote, although it is still higher than its corresponding place in the world in terms of the GDP per capita-measured economic development level alone ( $45^{\text {th }}$ in 2018 according to IMF data) [IMF, 2019].

\subsection{Comparative Assessment of Macroeconomic Performance}

An assessment of the current performance of the Polish economy will be based on a comparative analysis of five commonly used macroeconomic indicators: a) economic growth rate, b) unemployment rate, c) inflation rate, d) general government balance, e) current account balance. The tool used in this analysis is the pentagon of macroeconomic performance ${ }^{5}$.

The general condition of the Polish economy has been compared with the economic situation of six other CEE countries: three Visegrad Group member states (the

5 The author of the pentagon concept is Zbigniew Matkowski. A detailed description of the idea and its interpretation is provided in previous editions of the Report [see, e.g., Matkowski, Rapacki, Próchniak, 2016a]. 
Czech Republic, Slovakia, Hungary) and five Western European countries: Germany, France, Italy, Spain, and Sweden. The data concerning five indicators describing the overall macroeconomic performance of Poland and the reference countries in 2019 are provided in Table 3.6. Most of the data are preliminary estimates that may still undergo some changes. Figure 3.1 shows the data in the form of pentagons to facilitate comparative analysis.

Table 3.6. Main macroeconomic indicators in Poland and the selected EU countries in 2019

\begin{tabular}{|c|c|c|c|c|c|}
\hline Country & $\begin{array}{l}\text { GDP growth } \\
(\%)\end{array}$ & $\begin{array}{c}\text { Inflation } \\
(\%)\end{array}$ & $\begin{array}{c}\text { Unemployment } \\
(\%)\end{array}$ & $\begin{array}{c}\text { General } \\
\text { government } \\
\text { balance } \\
\text { (GDP \%) }\end{array}$ & $\begin{array}{l}\text { Current } \\
\text { account } \\
\text { balance } \\
\text { (GDP \%) }\end{array}$ \\
\hline \multicolumn{6}{|c|}{ Central and Eastern European countries } \\
\hline Czech Republic & 2.5 & 2.6 & 2.2 & 0.2 & -0.1 \\
\hline Estonia & 3.2 & 2.5 & 4.7 & 0.2 & 0.7 \\
\hline Lithuania & 3.4 & 2.3 & 6.1 & 0.5 & 1.1 \\
\hline Latvia & 2.8 & 3.0 & 6.5 & -0.8 & -1.8 \\
\hline Poland & 4.0 & 2.4 & 3.8 & -1.5 & -0.9 \\
\hline Slovakia & 2.6 & 2.6 & 6.0 & -0.8 & -2.5 \\
\hline Hungary & 4.6 & 3.4 & 3.5 & -1.8 & -0.9 \\
\hline \multicolumn{6}{|c|}{ Western European countries } \\
\hline France & 1.2 & 1.2 & 8.6 & -3.3 & -0.5 \\
\hline Spain & 2.2 & 0.7 & 13.9 & -2.2 & 0.9 \\
\hline Germany & 0.5 & 1.5 & 3.2 & 1.1 & 7.0 \\
\hline Sweden & 0.9 & 1.7 & 6.5 & 0.4 & 2.9 \\
\hline Italy & 0.0 & 0.7 & 10.3 & -2.0 & 2.9 \\
\hline
\end{tabular}

Note: All data are estimated. The inflation data represent the annual average growth rate of consumer prices. In addition, the economic growth rates provided in the table for Poland and for other CEE countries differ somewhat from the data in Table 1.3, which results from the use of different data sources.

Source: IMF [2020].

An analysis of the pentagons shows that in 2019 the overall condition of the Polish economy was relatively good. In general, the macroeconomic situation was then favorable, not only in Poland but also in other CEE countries. With few exceptions, CEE countries recorded a fast rate of economic growth, a low unemployment and inflation rate, and a low deficit or surplus of government budget, and current account. 
Figure 3.1. Macroeconomic performance of Poland and selected other EU member states in 2019

Czech Republic

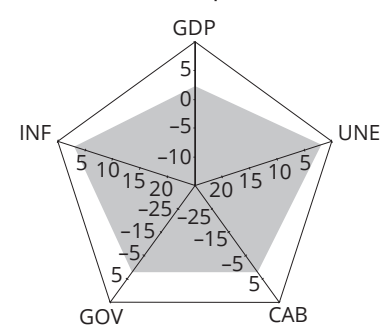

Estonia

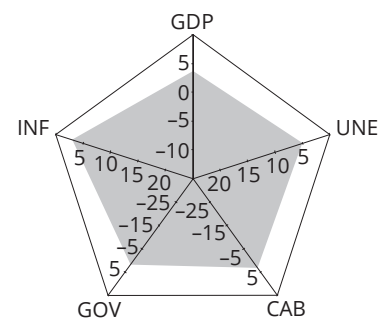

Poland

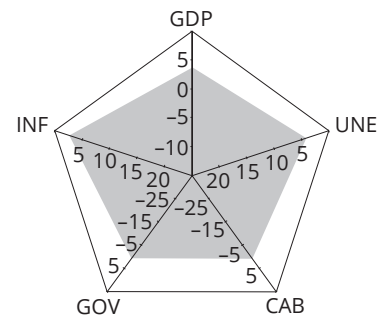

Germany

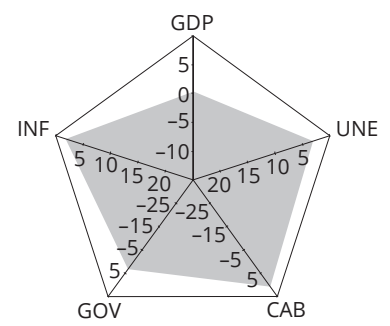

Slovakia

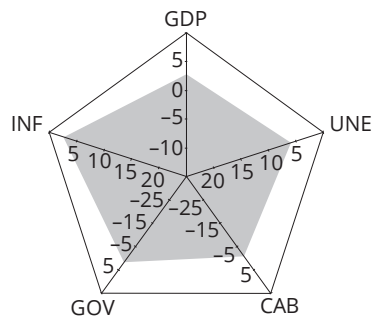

Lithuania

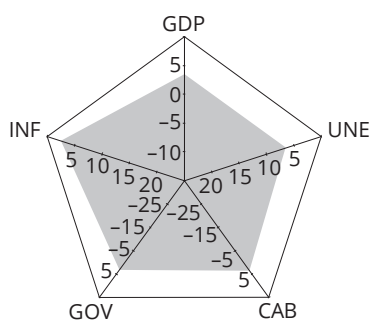

France

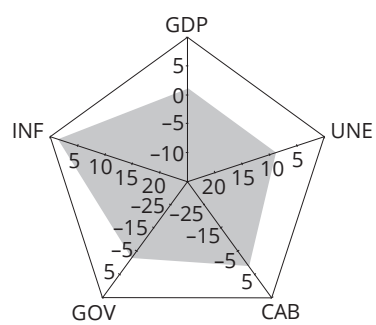

Sweden

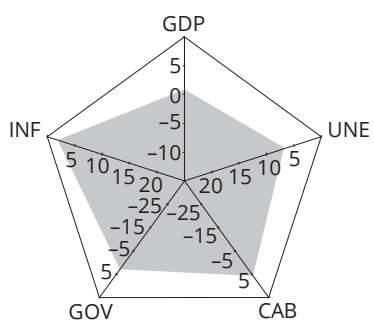

Hungary

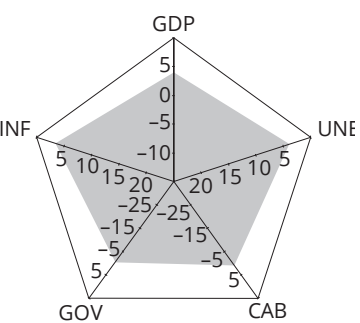

Latvia

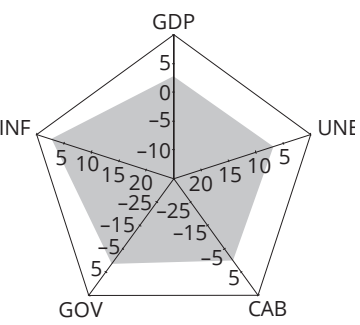

Spain

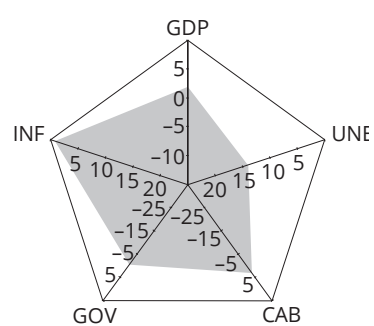

Italy

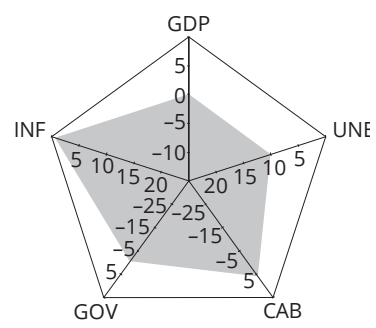

GDP - GDP growth rate (\%), INF - inflation rate (\%), UNE - unemployment rate (\%), GOV - general government balance ( $\%$ of GDP), CAB - current account balance (\% GDP).

Source: Own compilation based on data from Table 3.6. 
In terms of economic growth rate, in 2019 Poland ranked second only to Hungary. The economic growth rate in Poland was 4.0\% and in Hungary 4.6\%. In the other CEE countries, economic growth fell within the $2.5-3.4 \%$ bracket. Inflation in 2019 was $2.4 \%$, which secured Poland second place again (after Lithuania, where inflation was 2.3\%). CEE countries managed to reduce unemployment to a single-digit level. With the unemployment rate of $3.8 \%$, Poland found itself among the group's leaders, after the Czech Republic (2.2\%) and Hungary (3.5\%). Poland performed the worst in terms of the general government balance and the current account balance, although also in these categories Poland's results gave no rise to concern (government budget deficit equal to $1.5 \%$ of GDP and current account deficit of $0.9 \%$ of GDP in 2019).

Compared with Western European countries, the pentagon representing the overall performance of the Polish economy remains closest to the pentagons drawn for Sweden and Germany. Its area is slightly smaller, but its shape is more regular. Germany and Poland outperformed Poland with regard to three variables (inflation rate, general government balance, and current account balance), and Germany additionally in terms of unemployment rate. However, as regards the rate of economic growth, Germany's and Sweden's performance are no cause for pride - the growth of their economies practically came to a standstill with GDP growth rates of $0.5 \%$ and $0.9 \%$, respectively.

The overall condition of the Polish economy was better than that of France, Spain and Italy. The pentagons drawn for the three countries have very small areas and display a high degree of asymmetry. France, Spain and Italy report very poor results in terms of the unemployment rate. In 2019, it reached a double-digit level in Spain and Italy - at $13.9 \%$ and $10.3 \%$, respectively. It was also not much lower in France (8.6\%). The economic growth rate of France and Italy was very low (1.2\% and $0.0 \%$, respectively); a slightly higher rate was recorded in Spain (2.2\%). The government budgets of France and Spain showed a deficit of 2-3\% of GDP, the highest among all the countries analyzed in the pentagons.

The pentagons drawn for Western Europe show that the countries of that area performed well in terms of inflation rates and current account balance. In 2019, the inflation rate did not exceed $2 \%$ in those countries. Apart from France, which recorded a small deficit, four Western European countries achieved an external current account surplus. The better situation of the Western European countries in terms of external current account, compared with Central and Eastern Europe, should not come as a surprise, given the structure and technological advancement of the economies, structure and directions of imports of goods and services, or international expansion of their enterprises, and the related factor income flows between a given country and abroad. 
To sum up, it can be concluded that in terms of the five main macroeconomic indicators characterizing the general performance of the economy, Poland's results in 2019 were relatively good in the context of the overall economic situation in Europe.

\subsection{Sectoral Structure of the Economy}

The sectoral structure of the economy is assessed here on the basis of gross value added produced by individual sectors of the economy. The following sectors are taken into account in the analysis:

- A: agriculture, forestry, hunting and fishing;

- B-E: industry (without construction);

- F: construction;

- G-I: wholesale and retail trade, transportation, accommodation and food service activities;

- J: information and communication;

- K: financial and insurance activities;

- L: real estate activities;

- M-N: professional, scientific and technical activities; administrative and support service activities;

- O-Q: public administration and defense, education, human health and social work activities;

- R-U: arts, entertainment and recreation; other service activities; households and exterritorial organizations.

Figure 3.2 shows relevant data. In order to examine the course of changes of the economy structure over time, the latest data (for 2018) have been compared with 2004, i.e. the time the majority of CEE countries joined the EU. The data presented concern selected countries of Central and Eastern Europe and Western Europe - exactly the same states which have been analyzed in the pentagons.

Sectors $\mathrm{G}$ to $\mathrm{U}$ are treated here as services. This means that the category includes all sectors except agriculture, industry, and construction.

In 2018, Western European countries and the Baltic states represented the highest share of services in gross value added creation. The leader was France, where almost $80 \%$ of gross value added came from broadly defined service sectors. Spain and Italy ranked second and third in this category (74-75\%). A more than 70-percent share of service sectors in value added was also reported for Latvia and Sweden. In other countries, the share was lower than 70\%, with the Czech Republic, Slovakia and Poland ranking last in the classification (below 65\%). 
The sectoral structure of the economy was fairly stable during the period under study. According to the data shown in Figure 3.2, minor changes took place over the 14 years under analysis. For example, in Poland, the share of the three largest sectors contributing to GDP basically did not change between 2004 and 2018. Industry's contribution to gross value added creation decreased from $25,5 \%$ in 2004 to $25.0 \%$ in 2018. For their part, wholesale and retail, transport, accommodation and food service activities increased their share over the period from $25.0 \%$ to $25.9 \%$, and professional, scientific and technical activities, administrative and support service activities showed a decline from $15.5 \%$ to $14.5 \%$. As can be seen, the changes were not significant. Similar tendencies (but for few exceptions) occurred in other sectors and in the remaining countries under analysis.

Figure 3.2. Percentage of gross value added produced by sectors of the economy

Czech Republic in 2004

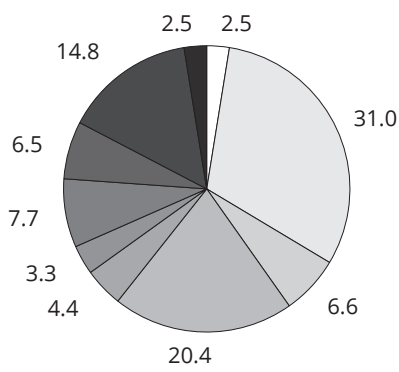

$\square \mathrm{A} \square \mathrm{B}-\mathrm{E} \quad \square \mathrm{F} \quad \square \mathrm{G}-\mathrm{I} \quad \square \mathrm{J} \quad \square \mathrm{K}$

$\square \mathrm{L} \square \mathrm{M}-\mathrm{N} \backsim \mathrm{O}-\mathrm{Q} \square \mathrm{R}-\mathrm{U}$

Estonia in 2004

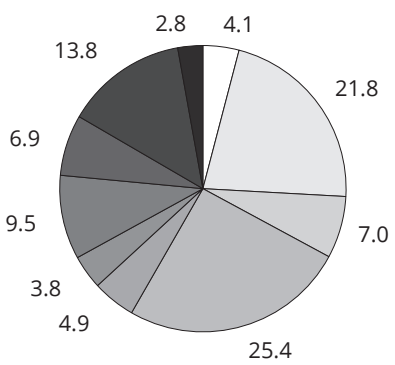

$\square \mathrm{A} \square \mathrm{B}-\mathrm{E} \quad \square \mathrm{F} \quad \square \mathrm{G}-\mathrm{I} \quad \square \mathrm{J} \quad \square \mathrm{K}$

$\square \mathrm{L} \square \mathrm{M}-\mathrm{N} \backsim \mathrm{O}-\mathrm{Q} \backsim \mathrm{R}-\mathrm{U}$
Czech Republic in 2018

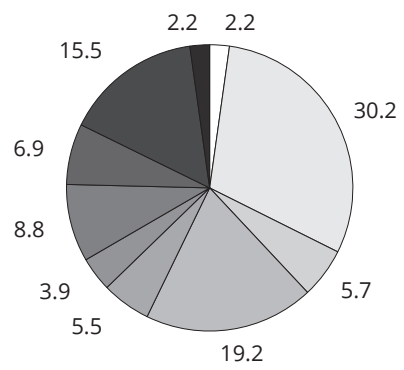

$\square \mathrm{A} \square \mathrm{B}-\mathrm{E} \quad \square \mathrm{F} \quad \square \mathrm{G}-\mathrm{I} \quad \square \mathrm{J} \quad \square \mathrm{K}$ $\square \mathrm{L} \square \mathrm{M}-\mathrm{N} \square \mathrm{O}-\mathrm{Q} \square \mathrm{R}-\mathrm{U}$

Estonia in 2018

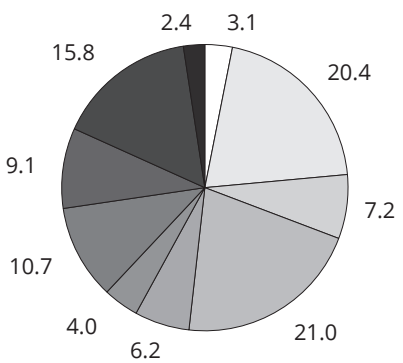

$\square \mathrm{A} \quad \square \mathrm{B}-\mathrm{E} \quad \square \mathrm{F} \quad \square \mathrm{G}-\mathrm{I} \quad \square \mathrm{J} \quad \square \mathrm{K}$

$\square \mathrm{L} \square \mathrm{M}-\mathrm{N} \backsim \mathrm{O}-\mathrm{Q} \backsim \mathrm{R}-\mathrm{U}$ 
Lithuania in 2004

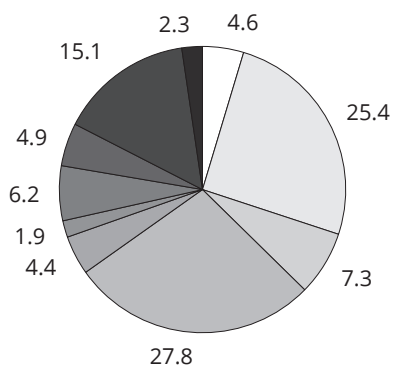

$\square \mathrm{A} \quad \square \mathrm{B}-\mathrm{E} \quad \square \mathrm{F} \quad \square \mathrm{G}-\mathrm{I} \quad \square \mathrm{J} \quad \square \mathrm{K}$ $\square \mathrm{L} \square \mathrm{M}-\mathrm{N} \square \mathrm{O}-\mathrm{Q} \square \mathrm{R}-\mathrm{U}$

Latvia in 2004

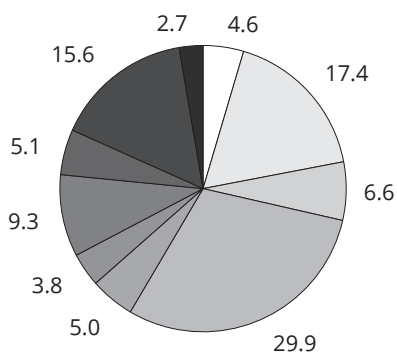
$\square \mathrm{A} \square \mathrm{B}-\mathrm{E} \quad \mathrm{F} \quad \square \mathrm{G}-\mathrm{I} \quad \square \mathrm{J} \quad \square \mathrm{K}$
$\square \mathrm{L} \square \mathrm{M}-\mathrm{N} \square \mathrm{O}-\mathrm{Q} \quad \mathrm{R}-\mathrm{U}$

Poland in 2004

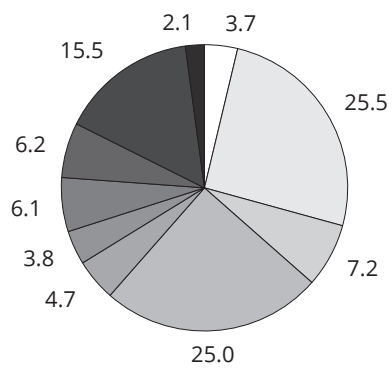

$\square \mathrm{A} \quad \square \mathrm{B}-\mathrm{E} \quad \square \mathrm{F} \quad \square \mathrm{G}-\mathrm{I} \quad \square \mathrm{J} \quad \square \mathrm{K}$ $\square \mathrm{L} \square \mathrm{M}-\mathrm{N} \square \mathrm{O}-\mathrm{Q} \square \mathrm{R}-\mathrm{U}$
Lithuania in 2018

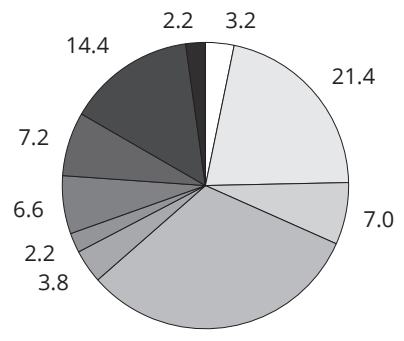

31.9

$\square \mathrm{A} \quad \square \mathrm{B}-\mathrm{E} \quad \square \mathrm{F} \quad \square \mathrm{G}-\mathrm{I} \quad \square \mathrm{J} \quad \square \mathrm{K}$

$\square \mathrm{L} \square \mathrm{M}-\mathrm{N} \square \mathrm{O}-\mathrm{Q} \square \mathrm{R}-\mathrm{U}$

Latvia in 2018

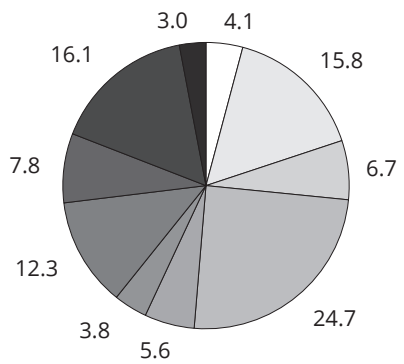

$\square \mathrm{A} \quad \square \mathrm{B}-\mathrm{E} \quad \square \mathrm{F} \quad \square \mathrm{G}-\mathrm{I} \quad \square \mathrm{J} \quad \square \mathrm{K}$ $\square \mathrm{L} \square \mathrm{M}-\mathrm{N} \square \mathrm{O}-\mathrm{Q} \square \mathrm{R}-\mathrm{U}$

Poland in 2018

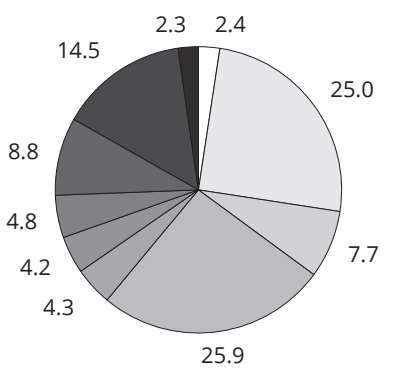

$\square \mathrm{A} \quad \square \mathrm{B}-\mathrm{E} \quad \square \mathrm{F} \quad \square \mathrm{G}-\mathrm{I} \quad \square \mathrm{J} \quad \square \mathrm{K}$ $\square \mathrm{L} \square \mathrm{M}-\mathrm{N} \square \mathrm{O}-\mathrm{Q} \square \mathrm{R}-\mathrm{U}$ 
Slovakia in 2004

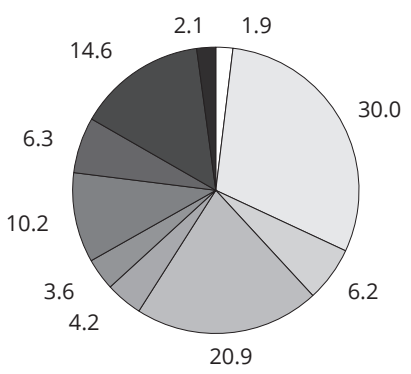

$\square \mathrm{A} \quad \square \mathrm{B}-\mathrm{E} \quad \square \mathrm{F} \quad \square \mathrm{G}-\mathrm{I} \quad \square \mathrm{J} \quad \square \mathrm{K}$

$\square \mathrm{L} \quad \mathrm{M}-\mathrm{N} \quad \mathrm{O}-\mathrm{Q} \quad \mathrm{R}-\mathrm{U}$

Hungary in 2004

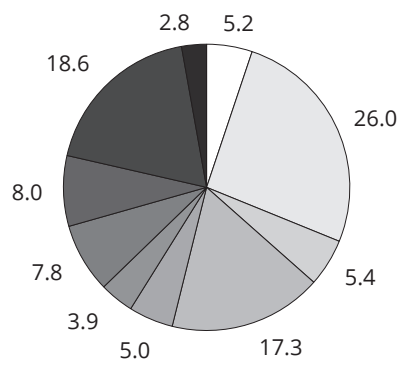

$\square \mathrm{A} \quad \square \mathrm{B}-\mathrm{E} \quad \square \mathrm{F} \quad \square \mathrm{G}-\mathrm{I} \quad \square \mathrm{J} \quad \square \mathrm{K}$

$\square \mathrm{L} \square \mathrm{M}-\mathrm{N} \square \mathrm{O}-\mathrm{Q} \square \mathrm{R}-\mathrm{U}$

France in 2004

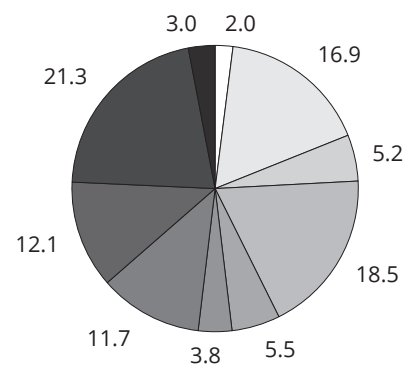

$\square \mathrm{A} \quad \square \mathrm{B}-\mathrm{E} \quad \square \mathrm{F} \quad \square \mathrm{G}-\mathrm{I} \quad \square \mathrm{J} \quad \square \mathrm{K}$

$\square \mathrm{L} \square \mathrm{M}-\mathrm{N} \square \mathrm{O}-\mathrm{Q} \quad \mathrm{R}-\mathrm{U}$
Slovakia in 2018

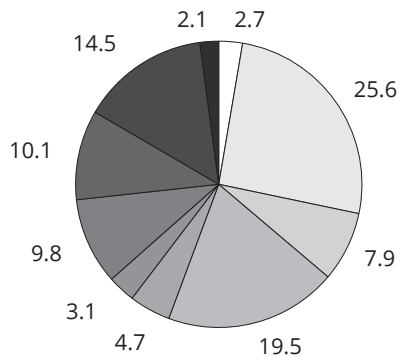

$\square \mathrm{A} \quad \square \mathrm{B}-\mathrm{E} \quad \square \mathrm{F} \quad \square \mathrm{G}-\mathrm{I} \quad \square \mathrm{J} \quad \square \mathrm{K}$

$\square \mathrm{L} \square \mathrm{M}-\mathrm{N} \square \mathrm{O}-\mathrm{Q} \square \mathrm{R}-\mathrm{U}$

Hungary in 2018

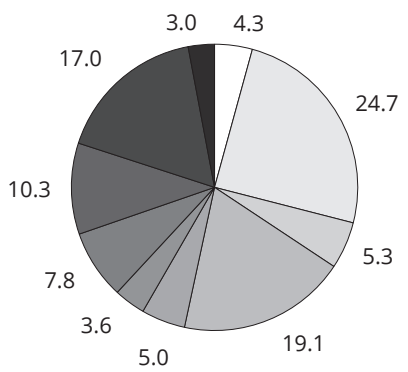

$\square \mathrm{A} \quad \square \mathrm{B}-\mathrm{E} \quad \square \mathrm{F} \quad \square \mathrm{G}-\mathrm{I} \quad \square \mathrm{J} \quad \square \mathrm{K}$

$\square \mathrm{L} \square \mathrm{M}-\mathrm{N} \square \mathrm{O}-\mathrm{Q} \square \mathrm{R}-\mathrm{U}$

France in 2018

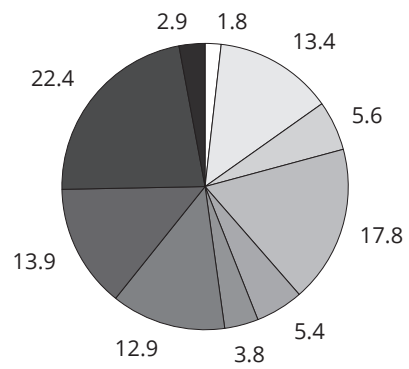

$\square \mathrm{A} \quad \square \mathrm{B}-\mathrm{E} \quad \square \mathrm{F} \quad \square \mathrm{G}-\mathrm{I} \quad \square \mathrm{J} \quad \square \mathrm{K}$ $\square \mathrm{L} \square \mathrm{M}-\mathrm{N} \square \mathrm{O}-\mathrm{Q} \square \mathrm{R}-\mathrm{U}$ 
Spain in 2004

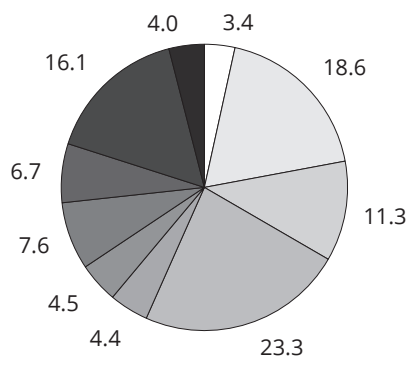

$\square \mathrm{A} \quad \square \mathrm{B}-\mathrm{E} \quad \square \mathrm{F} \quad \square \mathrm{G}-\mathrm{I} \quad \square \mathrm{J} \quad \square \mathrm{K}$ $\square \mathrm{L} \quad \mathrm{M}-\mathrm{N} \square \mathrm{O}-\mathrm{Q} \quad \mathrm{R}-\mathrm{U}$

Germany in 2004

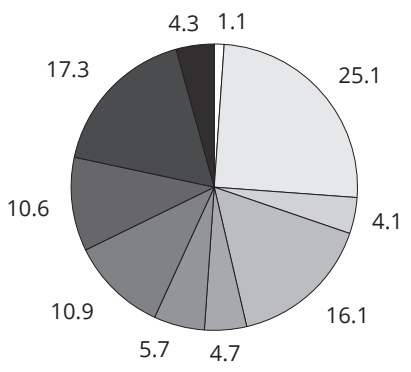

$\square \mathrm{A} \quad \square \mathrm{B}-\mathrm{E} \quad \square \mathrm{F} \quad \square \mathrm{G}-\mathrm{I} \quad \square \mathrm{J} \quad \square \mathrm{K}$

$\square \mathrm{L} \square \mathrm{M}-\mathrm{N} \square \mathrm{O}-\mathrm{Q} \square \mathrm{R}-\mathrm{U}$

Sweden in 2004

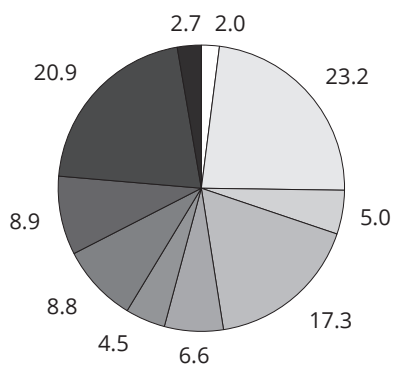

$\square \mathrm{A} \quad \square \mathrm{B}-\mathrm{E} \quad \square \mathrm{F} \quad \square \mathrm{G}-\mathrm{I} \quad \square \mathrm{J} \quad \square \mathrm{K}$

$\square \mathrm{L} \square \mathrm{M}-\mathrm{N} \square \mathrm{O}-\mathrm{Q} \square \mathrm{R}-\mathrm{U}$
Spain in 2018

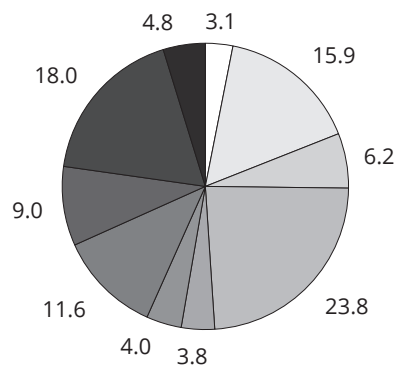

$\square \mathrm{A} \quad \square \mathrm{B}-\mathrm{E} \quad \square \mathrm{F} \quad \square \mathrm{G}-\mathrm{I} \quad \square \mathrm{J} \quad \square \mathrm{K}$

$\square \mathrm{L} \square \mathrm{M}-\mathrm{N} \square \mathrm{O}-\mathrm{Q} \quad \mathrm{R}-\mathrm{U}$

Germany in 2018

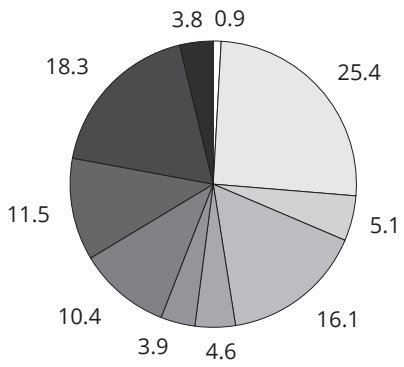

$\square \mathrm{A} \quad \square \mathrm{B}-\mathrm{E} \quad \square \mathrm{F} \quad \square \mathrm{G}-\mathrm{I} \quad \square \mathrm{J} \quad \square \mathrm{K}$

$\square \mathrm{L} \square \mathrm{M}-\mathrm{N} \square \mathrm{O}-\mathrm{Q} \square \mathrm{R}-\mathrm{U}$

Sweden in 2018

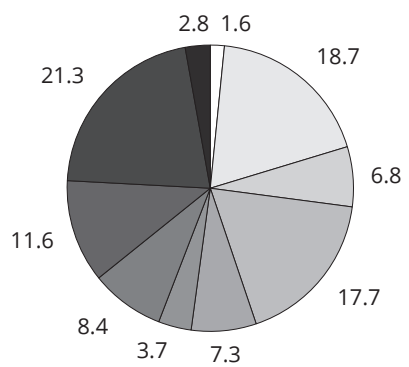

$\square \mathrm{A} \quad \square \mathrm{B}-\mathrm{E} \quad \square \mathrm{F} \quad \square \mathrm{G}-\mathrm{I} \quad \square \mathrm{J} \quad \square \mathrm{K}$ $\square \mathrm{L} \square \mathrm{M}-\mathrm{N} \square \mathrm{O}-\mathrm{Q} \square \mathrm{R}-\mathrm{U}$ 
Italy in 2004

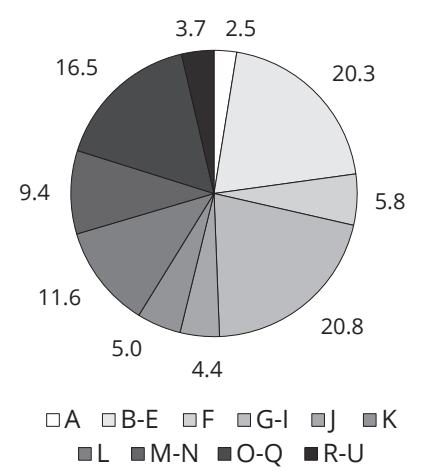

Italy in 2018

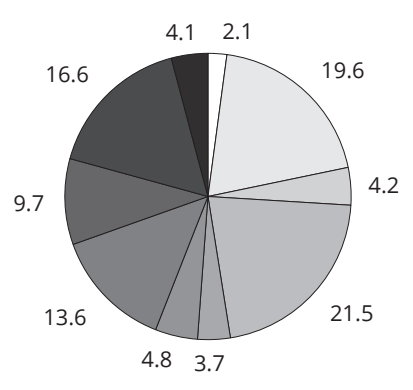

$\square$ A $\square$ B-E $\square F \quad \square G-I \quad \square J \quad \square K$

$\square \mathrm{L} \square \mathrm{M}-\mathrm{N} \backsim \mathrm{O}-\mathrm{Q} \backsim \mathrm{R}-\mathrm{U}$

Source: Own compilation based on Eurostat data [Eurostat, 2020].

\section{Bibliography}

European Commission [2019], Statistical Annex of European Economy, Autumn, https://ec.europa. eu/info/sites/info/files/economy-finance/saee_autumn_2019_en.pdf (5.02.2020).

Eurostat [2020], https://ec.europa.eu/eurostat/data/database (3.02.2020).

IMF [2005], World Economic Outlook Database, September.

IMF [2019], World Economic Outlook Database, April.

IMF [2020], World Economic Outlook Database, October 2019 (updated January 2020), www. imf.org, access 6.02.2020.

Matkowski, Z., Rapacki, R., Próchniak, M. [2016], Comparative Economic Performance: Poland and the European Union, in: M.A. Weresa (ed.), Poland. Competitiveness Report 2016. The Role of Economic Policy and Institutions, SGH Warsaw School of Economics, Warsaw, pp. 37-55.

Matkowski, Z., Rapacki, R., Próchniak, M. [2016b], Income Convergence in Poland vis-à-vis the EU: Major Trends and Prospects, in: M.A. Weresa (ed.), Poland. Competitiveness Report 2016. The Role of Economic Policy and Institutions, SGH Warsaw School of Economics, Warsaw, pp. 39-59.

Rapacki, R., Próchniak, M. [2019], Development of the Polish Economy in 2010-2018 Compared with Other EU Countries, in: A.M. Kowalski, M.A. Weresa (eds.), Poland. Competitiveness Report 2019. International Competitiveness in the Context of Development of Industry 4.0, SGH Publishing House, Warsaw, pp. 71-87.

UNDP [2019], Human Development Report 2019. Beyond income, beyond averages, beyond today: Inequalities in human development in the 21st century, United Nations Development Programme, New York.

United Nations [2020], World Economic Situation and Prospects 2020, New York. 

Chapter 4

\title{
Income Convergence of Poland to the Average EU Level
}

\author{
Mariusz Próchniak
}

\subsection{Introduction}

This chapter presents the results of an analysis of income convergence of 11 Central and Eastern European countries that joined the European Union in 2004, 2007 and 2013, i.e., Poland, Bulgaria, Croatia, the Czech Republic, Estonia, Lithuania, Latvia, Romania, Slovakia, Slovenia, and Hungary (EU-11). The development trajectories of these countries are analyzed in relation to the former $15 \mathrm{EU}$ member states (EU-15). The study is a continuation of research, presented in previous editions of the Report [see, e.g., Matkowski, Próchniak, Rapacki, 2016a; Próchniak 2017, 2018, 2019]. The 2013 edition of the report also includes an analysis of regional convergence covering all EU member states [Matkowski and Próchniak, 2013].

\subsection{Theory}

Models of economic growth constitute the theoretical framework for the analysis of convergence in the level of income. Neoclassical models of economic growth [e.g., Solow, 1956; Mankiw, Romer, Weil, 1992] confirm the existence of conditional $\beta$-convergence. It occurs when less developed countries (with lower GDP per capita) show a faster rate of economic growth than more developed ones. The convergence is conditional because it occurs only when all countries tend to the same long-term equilibrium (steady state). The $\beta$ convergence hypothesis can be explained using the Solow model [see, e.g., Rapacki, Próchniak, 2012; Próchniak and Witkowski, 2012].

In the Solow model, the basic equation describing the dynamics of the economy tending to a steady state takes the following form:

$$
\dot{k}=s f(k)-(n+a+\delta) k,
$$


where: $k$-capital per unit of effective labor in year $t, \dot{k}$-change of $k$ in a time unit (from a mathematical point of view, it is a derivative of $k$ with respect to time), $s$-savings rate, $f(k)$ - production function (expressed per unit of effective labor), $n$-population growth rate, $a$ - rate of exogenous technical progress, $\delta$ - capital depreciation rate.

In the analysis of the Solow model with technical progress, the symbols $k$ and $f(k)$ mean, capital and output, respectively, per unit of effective labor, which in this case is a product of the level of technology and labor input.

If we assume that the production function is of the Cobb-Douglas type with the form $f(k)=k^{\alpha}(0<\alpha<1)$, equation (4.1) assumes the following form:

$$
\dot{k}=s k^{\alpha}-(n+a+\delta) k
$$

By dividing equation (4.2) by $k$, we obtain a formula for the growth rate of capital per unit of effective labor during the transition period towards the steady state:

$$
\frac{\dot{k}}{k}=s k^{\alpha-1}-(n+a+\delta) \text {. }
$$

As output is directly proportional to capital, the analogous equation characterizes the dynamics of GDP growth per unit of effective labor.

Figure 4.1. Economic growth in the Solow model

(a)

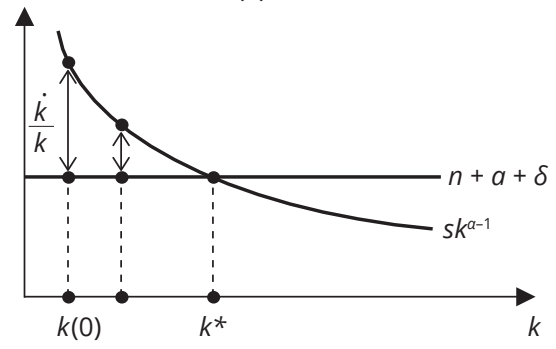

(b)

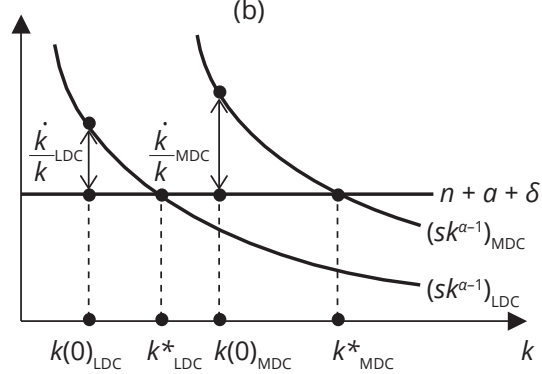

Source: Own study.

The best way to illustrate the convergence hypothesis is to graphically analyze equation (4.3). It is represented in Figure 4.1. The rate of growth is equal to the vertical distance between the $s k^{\alpha-1}$ curve and the $n+a+\delta$ straight line. As can be seen, the economy, which starts with the initial capital level $k(0)$ and reaches the capital level in long-term equilibrium $k^{*}$, shows a decreasing rate of economic growth. The convergence is conditional because it occurs only when both economies tend to the same steady-state. 
In order to illustrate the conditional character of the convergence phenomenon, let us consider a case of two countries: a more developed country (MDC) and a less developed country (LDC), in which the savings rates are different. Because the savings rate in a more developed country is higher, the capital level in a steady-state will also be greater. This is depicted in part (b) of Figure 4.1. Although a more developed country starts from a higher capital level, it shows faster economic growth because it is moving toward a different long-term equilibrium. In this situation, convergence will not occur.

An important goal of empirical research is to estimate the value of parameter $\beta$, which represents the speed of the process of convergence relative to a steady state, according to the following equation:

$$
\frac{\dot{y}}{y}=\beta\left(\ln y^{*}-\ln y\right)
$$

where: $y$ - output per unit of effective labor in year $t, \dot{y}$ - change of $y$ in time unit (derivative with respect to time), $y^{*}$ - output per unit of effective labor in steady state.

Parameter $\beta$ represents the distance which is covered by the economy tending towards the steady state during one period (year). For example, if $\beta=0.02$, the economy covers $2 \%$ of the distance concerned each year.

Another type of catching-up is $\sigma$-convergence. It occurs when the income differential between countries decreases over time. The income differential can be measured by the standard deviation, variance or coefficient of variation of GDP per capita levels between countries or regions.

From a theoretical perspective, $\sigma$-convergence is a necessary but insufficient condition of $\beta$-convergence. Therefore, it is possible (though unlikely) that the differences in the level of income between economies will be growing over time and at the same time a less developed country will show a faster rate of economic growth.This can happen when the less developed country reaches such a fast rate of economic growth that it outstrips the more developed country in terms of income level and the differences in the development level in the final period will be higher than at the beginning.

\subsection{Method}

To verify the occurrence of absolute $\beta$-convergence, we estimate the following regression equation:

$$
\frac{1}{T} \ln \frac{y_{T}}{y_{0}}=\alpha_{0}+\alpha_{1} \ln y_{0}+\varepsilon_{t}
$$


where $y_{T}$ and $y_{0}$ are income per capita in the final and initial year, while $\varepsilon_{t}$ is a random factor. Thus, the average annual growth rate of real GDP per capita calculated at purchasing power parity (PPP) between period $T$ and 0 is the explained variable, while the natural logarithm of GDP per capita in the initial period is the explanatory variable. If the $\alpha_{1}$ parameter is negative and statistically significant (in the empirical analysis, we assumed a significance level of $10 \%), \beta$-convergence exists. In such a situation, we can calculate the value of coefficient $\beta$, expressing the speed of convergence ${ }^{1}$ :

$$
\beta=-\frac{1}{T} \ln \left(1+\alpha_{1} T\right)
$$

In order to verify the occurrence of $\sigma$-convergence, we estimate the trend line in order to differentiate income levels between countries:

$$
\operatorname{sd}\left(\ln y_{t}\right)=\alpha_{0}+\alpha_{1} t+\varepsilon_{t}
$$

where $s d$ is the standard deviation, while $t$ - time $(\mathrm{t}=1, \ldots, 27$ for the period 1993-2019). Thus, the explained variable is the standard deviation of natural logarithms of GDP per capita levels between countries, while time is the explanatory variable. If the $\alpha_{1}$ parameter is negative and statistically significant, $\sigma$-convergence exists.

\subsection{Empirical Evidence}

The study presented covers the years 1993-2019. All calculations have also been made for three sub-periods: 1993-2000, 2000-2008 and 2008-2019, which allows the temporal stability of the phenomenon under consideration to be analyzed. It also makes it possible to approximately determine the strength of impact of many other, deeper factors on the rate of income disparity reduction.

1 Barro and Sala-i-Martin [2003, p. 467], when analyzing $\beta$-convergence using the neoclassical model, derive an equation presenting the relationship between the average rate of economic growth and the initial level of income:

$$
(1 / T) \ln \left(y_{i T} / y_{i 0}\right)=a-\left[\left(1-e^{-\beta T}\right) / T\right] \ln \left(y_{i 0}\right)+w_{i 0, T},
$$

where $y_{i T}$ and $y_{i 0}-$ GDP per capita in country $i$ in the final and initial year, $T$ - time period, $\beta$-convergence rate, $a$ - constant, $w_{i 0, T}$-random factor. The coefficient at the initial income level, i.e., $-\left[\left(1-e^{-\beta T}\right) / T\right]$ equals parameter $\alpha_{1}$ in formula (4.5). Thus, from the equation $\alpha_{1}=-\left[\left(1-e^{-\beta T}\right) / T\right]$ we obtain the formula (4.6). For a small $T$, estimation of the parameter in regression equation $\alpha_{1}$ will be very close to coefficient $\beta$, because with $T$ tending to zero the expression $\left(1-e^{-\beta T}\right) / T$ tends to $\beta$. 
Table 4.1. Results of estimation of regression equations describing $\beta$-convergence

\begin{tabular}{|c|c|c|c|c|c|c|c|c|c|}
\hline Time period & $a_{0}$ & $a_{1}$ & $\begin{array}{c}t \text {-stat. } \\
\left(\mathrm{a}_{0}\right)\end{array}$ & $\begin{array}{c}t \text {-stat. } \\
\left(a_{1}\right)\end{array}$ & $\begin{array}{c}p \text {-value } \\
\left(a_{0}\right)\end{array}$ & $\begin{array}{c}p \text {-value } \\
\left(\mathrm{a}_{1}\right)\end{array}$ & $R^{2}$ & $\beta$-convergence & $\beta$ \\
\hline \multicolumn{10}{|c|}{26 countries of enlarged EU } \\
\hline 1993-2019 & 0.2154 & -0.0193 & 7.65 & -6.79 & 0.000 & 0.000 & 0.6578 & yes & 0.0195 \\
\hline 1993-2000 & 0.0699 & -0.0036 & 1.20 & -0.62 & 0.241 & 0.541 & 0.0157 & no & - \\
\hline $2000-2008$ & 0.4230 & -0.0385 & 9.33 & -8.60 & 0.000 & 0.000 & 0.7551 & yes & 0.0392 \\
\hline 2008-2019 & 0.1951 & -0.0177 & 3.18 & -2.99 & 0.004 & 0.006 & 0.2717 & yes & 0.0178 \\
\hline \multicolumn{10}{|c|}{2 regions (EU-11 and EU-15) } \\
\hline 1993-2019 & 0.2585 & -0.0238 & - & - & - & - & 1.0000 & yes & 0.0241 \\
\hline 1993-2000 & 0.1437 & -0.0115 & - & - & - & - & 1.0000 & yes & 0.0116 \\
\hline 2000-2008 & 0.4481 & -0.0415 & - & - & - & - & 1.0000 & yes & 0.0424 \\
\hline 2008-2019 & 0.3716 & -0.0346 & - & - & - & - & 1.0000 & yes & 0.0353 \\
\hline
\end{tabular}

Source: Own study.

Figure 4.2. Relationship between the GDP per capita growth rate in 1993-2019 and the level of GDP per capita at the beginning of the period

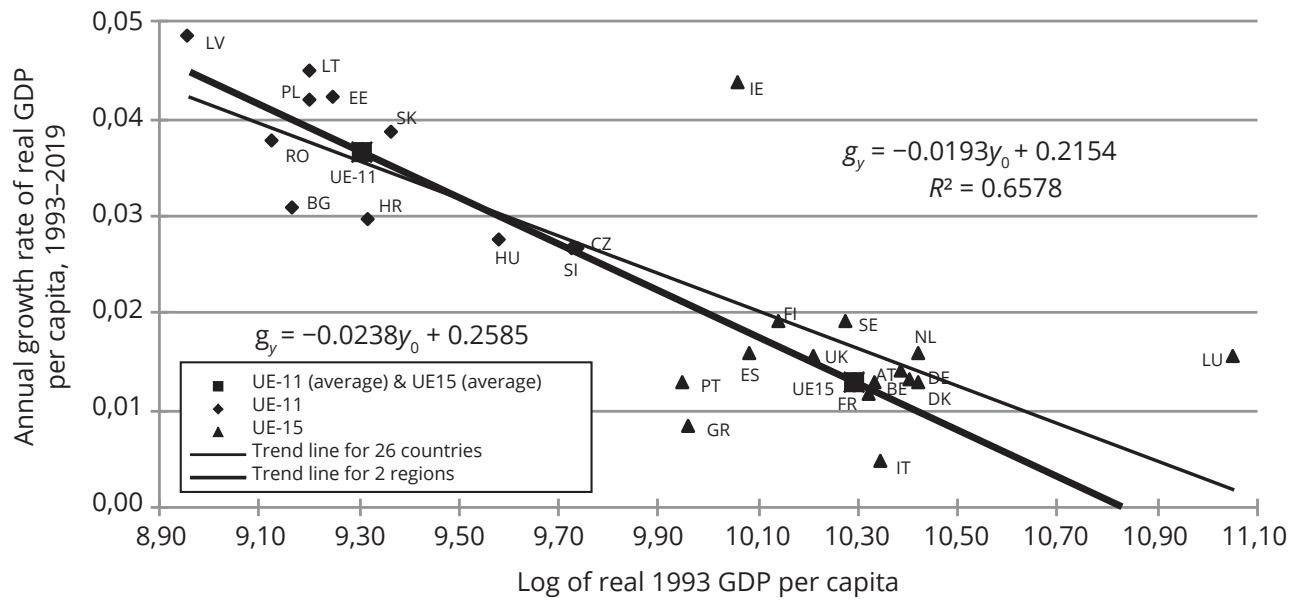

Source: Own study.

The calculations use time series of real GDP per capita at purchasing power parity (in USD) obtained from the International Monetary Fund data [IMF, 2018]. Unlike the previous editions of the study, in this analysis GDP per capita time series have been taken from the IMF database, expressed in constant prices. Previously, the IMF published values of this variable in current prices only, and conversion to constant prices was made by the author. Therefore, the results presented in this paper (relating to the 
first two sub-periods) may differ slightly from the corresponding results described in previous editions of the Report.

The results of the $\beta$-convergence analysis of the EU-11 to the EU-15 countries are presented in Table 4.1 and in Figure 4.2. The analyzed convergence concerns both the $26 \mathrm{EU}$ member states and two regions covering the EU-11 and EU-15 areas. The aggregated data for the two areas are weighted averages with variable weights reflecting the population number of a given country included in a particular group in a given year.

The results obtained confirm the existence of clear income convergence of the EU-11 to the EU-15 countries throughout the analyzed period, i.e., 1993-2019. The convergence observed occurred both among the 26 countries of the examined group and between the two areas concerned, EU-11 and EU-15. Countries with lower income levels in 1993 showed, on average, a faster rate of economic growth in 1993-2019 than countries initially better developed. As the group of less developed countries in 1993 consisted of the Central and Eastern Europe countries, these results confirm the clear convergence of the EU-11 countries to the average level of income in Western Europe.

The analysis of Figure 4.2 shows that the distribution of points representing individual states fits quite well with the negatively sloped trend line. This results in a relatively high value of the determination coefficient at a level exceeding $65 \%$. Thus, differences in the initial income level account for almost $2 / 3$ of the economic growth rate differential in 1993-2019.

Looking at the points representing particular countries, the situation of the individual countries can be compared and, in respect to this perspective, the changes in their competitive position over the whole period can be assessed. The fastest rate of economic growth among the Central and Eastern European countries was recorded in the Baltic states and Poland. Latvia, Lithuania, Estonia, and Poland showed economic growth in the years 1993-2019 exceeding 4\% annually, with a relatively low initial income level. Slovakia also reported a rate of economic growth of around $4 \%$, but its initial level of income was slightly higher. The performance of those countries amplified the convergence tendency in the group as a whole. As can be seen, the situation of Poland compared to other countries is favorable. Poland ranked $4^{\text {th }}$ among the 11 countries of Central and Eastern Europe in terms of the average rate of economic growth in 1993-2019, which became one of the factors behind consolidating the competitive position of the Polish economy.

Aggregated data for two areas: EU-11 and EU-15 also confirm the existence of convergence in 1993-2019. In Figure 4.2, the points representing these two areas are marked with squares. The EU-11 group as a whole showed faster economic growth than the EU-15 with a much lower initial level of income. 
The coefficients $\beta$ representing the speed of the convergence process are as follows: $1.95 \%$ for the group of 26 countries under consideration and $2.41 \%$ for the two analyzed areas. They enable the time needed to reduce the development gap between the countries under study to be estimated. Namely, given that the average economic growth rate witnessed over the 1993-2019 period is maintained, the countries of the enlarged EU will need about 30-35 years to halve the distance separating them from the common hypothetical steady state (this result has been calculated as follows: -ln $(0.5) / 0.0195=35.5$ years and $-\ln (0.5) / 0.0241=28.8$ years $)$. This means a slow convergence of the EU-11 countries with Western Europe. Based on these estimates, it is difficult to expect a quick equalization of income levels between Poland and other Central and Eastern European countries as well as Western Europe in the medium term. ${ }^{2}$

It is also worth checking how the stability of the convergence processes developed over time. It turns out that in the separate sub-periods the speed of convergence was very diversified. The high instability of the convergence rate in the countries under study was caused, inter alia, by the global crisis, as well as a diverse impact on economic growth of institutional factors, related, e.g., to EU membership. In the case of the 26 EU countries concerned, in the years 1993-2000, there was no statistically significant reduction in the income gap between the EU-11 and the EU-15 countries (in average terms for the whole group). For the years 1993-2000, the slope of the trend line is negative but not statistically significant. Such estimation results of the model show the actual lack of convergence, despite the negative slope of the trend line. A very strong acceleration of the convergence rate occurred in 2000-2008, which undoubtedly had its source in the EU enlargement. A clear tendency towards convergence during the early years of the first decade of the $21^{\text {st }}$ century was weakened significantly after 2008. This was largely due to the global crisis in that period.

The presented $\beta$-convergence results are averaged values for the entire region. As can be seen in Figure 4.2, individual CEE countries showed different dynamics of economic growth and different degrees of convergence to Western Europe. It is worth analyzing the status of convergence of the particular EU-11 countries relative to the EU-15 in the separated sub-periods.

Figure 4.3 shows a decrease in the income gap (in pp) of a given EU-11 country in relation to the EU-15 in the years 1993-2000, 2000-2008 and 2008-2019. The data

2 This result should be looked at with some reserve, as it is based on model assumptions which may or may not prove correct in reality. The occurrence of a decreasing marginal productivity of capital (in accordance with the neoclassical production function), as well as the fact that economies tend towards the steady state and will reach that state in infinity. Therefore, in interpreting those results, it makes sense to state the half-life instead of the period needed to completely close the income gap. It is worth comparing those results with other forecasts, presented in the SGH report at the Economic Forum in Krynica-Zdrój, which show that Poland will catch up with the EU-15 group in a dozen or so years [Próchniak et al., 2019]. 
presented confirm the conclusions of the $\beta$-convergence analysis. Namely, in the case of all the EU-11 countries, except Poland and, to a lesser extent, Hungary, the fastest closing of the income gap in relation to Western Europe occurred in 2000-2008. For the three Baltic states and Slovakia, the income gap in that period decreased by over 20 pp, and for the Czech Republic, Slovenia, Bulgaria, and Romania - by 15-18 pp. Poland was a country that did not improve its relative development level until recent years. While in the 1993-2000 and 2000-2008 periods Poland reduced the income gap in relation to Western Europe by 8 and 10 pp, respectively, in the years 2008-2019 this process accelerated, and Poland managed to reduce the income gap by $20 \mathrm{pp}$. It can be expected that in the case of Poland, an important role in accelerating the pace of convergence after the EU enlargement was played by the European funds that increased the competitiveness of Poland's economy. Poland was the largest beneficiary of the EU funds under the 2007-2013 budget. The stream of funding from the EU in implementation of various support programs positively influenced the growth of the Polish economy on the demand and supply sides, thanks to which Poland achieved relatively good results in terms of economic growth in recent years (e.g., it was the only EU country that avoided the recession during the last global crisis). The EU budget for 2014-2020 and the continuation of a large inflow of structural funds to the new member states is also one of the factors conducive to maintaining the pace of Poland's convergence to Western Europe in the last analyzed sub-period.

Figure 4.3. Extent of income gap closing between the EU-11 and the EU-15 countries in three consecutive subperiods*

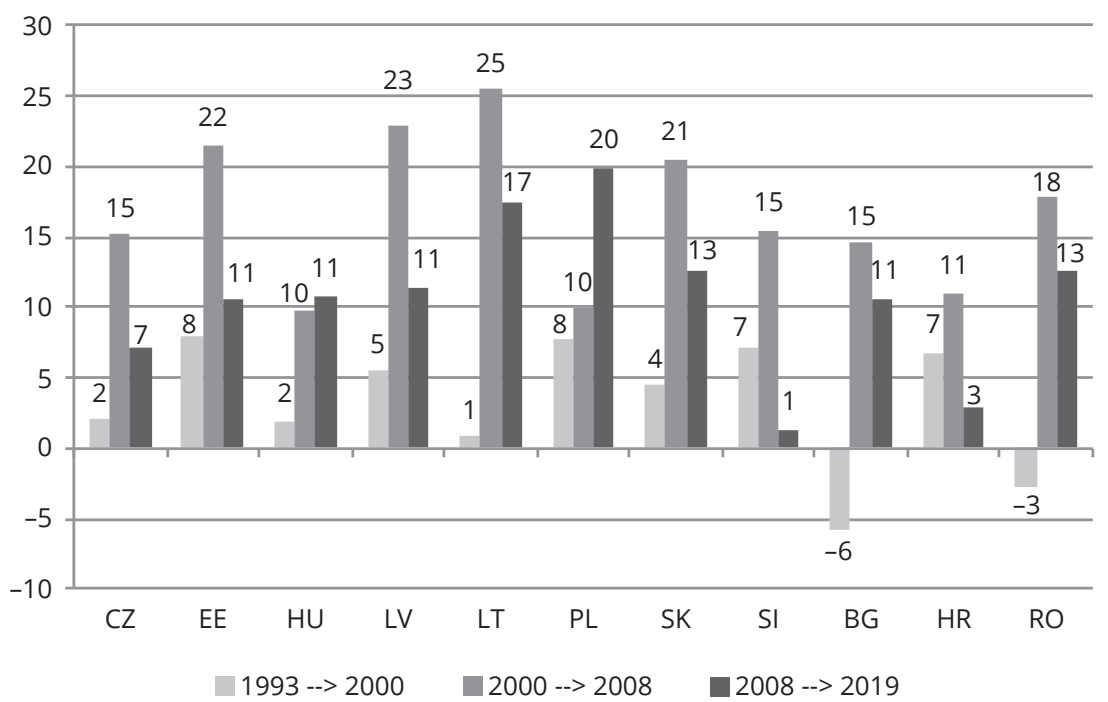

* The changes are expressed in pp; for each year, the EU-15 GDP per capita at PPP is taken as 100.

Source: Own calculations based on IMF data [IMF, 2020]. 
$\sigma$-convergence of the Central and Eastern European countries to Western Europe is measured by changes in the standard deviation of the natural logarithms of GDP per capita between the 26 EU countries, as well as between the two areas, the EU-11 and the EU-15. The results of the trend line estimation relating to standard deviations are presented in Table 4.2, and Figure 4.4 contains their graphical presentation.

Table 4.2. Results of estimation of regression equations describing $\sigma$-convergence

\begin{tabular}{|l|c|c|c|c|c|c|c|c|c|}
\hline Time period & $a_{0}$ & $a_{1}$ & $\begin{array}{c}t \text {-stat. } \\
\left(a_{0}\right)\end{array}$ & $\begin{array}{c}t \text {-stat. } \\
\left(a_{1}\right)\end{array}$ & $\begin{array}{c}p \text {-value } \\
\left(a_{0}\right)\end{array}$ & $\begin{array}{c}p \text {-value } \\
\left(a_{1}\right)\end{array}$ & $R^{2}$ & $\sigma$-convergence \\
\hline \multicolumn{7}{|c|}{26 countries of enlarged EU } \\
\hline $1993-2019$ & 0.5683 & -0.0093 & 74.65 & -19.49 & 0.000 & 0.000 & 0.9383 & yes \\
\hline $1993-2000$ & 0.5357 & -0.0010 & 92.67 & -0.91 & 0.000 & 0.399 & 0.1206 & no \\
\hline $2000-2008$ & 0.5540 & -0.0192 & 492.81 & -96.19 & 0.000 & 0.000 & 0.9992 & yes \\
\hline $2008-2019$ & 0.3989 & 0.0051 & 98.53 & -9.28 & 0.000 & 0.000 & 0.8960 & yes \\
\hline & & & 2 regions (EU-11 and EU-15) & & yes \\
\hline $1993-2019$ & 0.5230 & -0.0124 & 83.76 & -31.79 & 0.000 & 0.000 & 0.9759 & yes \\
\hline $1993-2000$ & 0.4884 & -0.0054 & 70.06 & -3.93 & 0.000 & 0.008 & 0.7198 & yes \\
\hline $2000-2008$ & 0.4802 & -0.0192 & 131.98 & -29.67 & 0.000 & 0.000 & 0.9921 & yes \\
\hline $2008-2019$ & 0.3197 & $-0,0104$ & 101.08 & -24.32 & 0.000 & 0.000 & 0.9834 & yes \\
\hline
\end{tabular}

Source: Own study.

Figure 4.4. Standard deviation of GDP per capita in 1993-2019

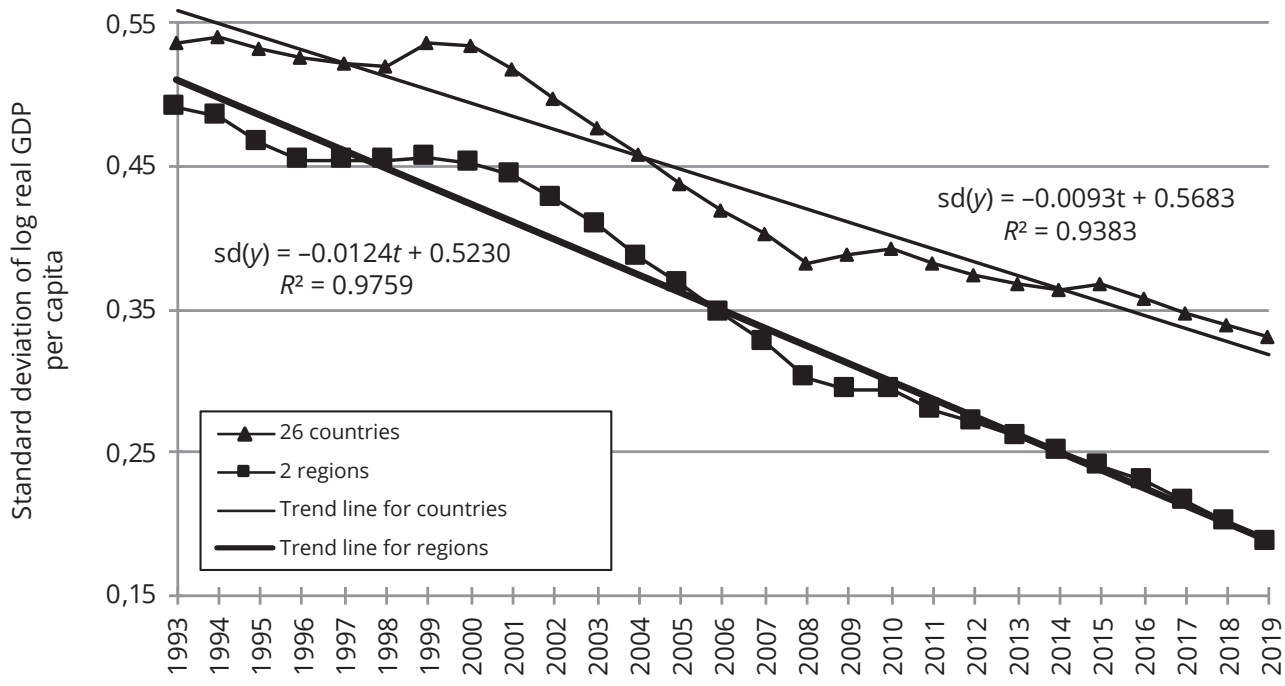

Source: Own study. 
The data presented contained in Table 4.2 show that for the whole period there was a $\sigma$-convergence both among the $26 \mathrm{EU}$ countries and between the the two areas under consideration, the EU-11 and the EU-15. The slopes of both estimated trend lines are negative and statistically significant at very high significance levels (as demonstrated by $p$-values equal to 0.000). High values of determination coefficients (over 90\%) reflect a very good fit of empirical points to the trend line.

Figure 4.4 shows the tendency of standard deviation of log GDP per capita levels. As can be seen, the income differential between the new and the old EU member states showed, in general, a downward trend. The most visible and systematic decrease in income disparities occurred in the second part of the analyzed period, i.e., from 2000 onwards. In 2009 and 2010 - as a result of the economic crisis and declining GDP growth rate in many previously fast developing countries - income disparities among the 26 countries of the group under study increased, although this is not confirmed by the data averaged for the two areas.

\subsection{Discussion}

There is much empirical research on the phenomenon of convergence, and it is impossible to list all of it here. A detailed review of the latest empirical research includes the article by Matkowski, Próchniak and Rapacki [2016b], while the books by Malaga [2004], Michałek, Siwiński and Socha [2007], Liberda [2009], Batóg [2010] and Jóźwik [2017] are entirely or largely devoted to the phenomenon of convergence in the countries of the European Union or the OECD.

Comparing the results obtained in the analysis presented with studies by other researchers, it should be emphasized that in recent years studies indicating the possibility of divergence in Europe (both at the national and regional level) have been increasingly frequent. For example, Mucha [2012] suggests that for some euro area countries having a single currency may be a source of many problems and the emergence of economic divergence in relation to other members of the Economic and Monetary Union. Monfort, Cuestas and Ordóñez [2013] analyze the real convergence of GDP per worker in 23 EU countries in 1980-2009 (Western European countries) and 1990-2009 (Central and Eastern European countries), showing that - using the club convergence research techniques - there is a strong case for the existence of per capita income divergence in the EU as a whole; however, for example, the countries of Central and Eastern Europe (excluding the Czech Republic but including Greece) form a group showing convergence. Borsi and Metiu [2013] analyze the real convergence of the $27 \mathrm{EU}$ countries in the years 1970-2010, reaching the conclusion that there is 
no convergence of per capita income levels in the whole group and that there is convergence in the subgroups of countries that tend to different steady states. Staňisić [2012] analyzes $\beta$-convergence in the EU-25 and within two groups of countries: EU-15 and EU-10, confirming the existence of $\beta$-convergence in the EU-25 (which means the convergence of the new EU member states to Western Europe) and denying the convergence within the EU-15 and the EU-10. The author of the quoted study also claims that during the recent crisis income disparities between the EU-25 countries increased, but the scale and time range of that increase were limited and did not affect the longterm convergence path, which is a conclusion very similar to the results of the study presented in this chapter.

The convergence process is not an automatic phenomenon. Despite the strong tendency of decreasing income disparities between Central and Eastern Europe and Western Europe in recent years, there is no guarantee that this situation will persist in the future (as evidenced by the temporal instability of the results presented above and increasingly frequent references in the literature to the possibility of divergence tendencies emerging in Europe). Thus, it is an extremely important task for economic policy-makers to pursue measures that will enable the current long-term trends of economic growth in Europe to be maintained, characterized by reducing the income differences between the eastern and western areas of our continent.

\subsection{Conclusions}

In the group of 26 countries of the enlarged European Union, income convergence occurs both in terms of $\beta$ and $\sigma$ convergence concepts. The rate of economic growth in 1993-2019 was negatively dependent on the initial level of GDP per capita. The new EU member states from Central and Eastern Europe achieved a faster rate of economic growth than the Western European countries, although the initial level of GDP per capita in the Central and Eastern European countries was much lower. Disparities in the level of income decreased, especially in the years 2000-2008, although they are still very large.

However, a reduction in the differences in competitiveness measured by the standard of living of the societies of the old and the new EU countries cannot be expected unconditionally in the short-term perspective. Acceleration of the convergence process will depend, among other things, on a properly conducted economic policy aimed at reducing differences in the level of development between Central and Eastern Europe and Western Europe. 


\section{Bibliography}

Barro, R., Sala-i-Martin, X. [2003], Economic Growth, The MIT Press, Cambridge - London.

Batóg, J. [2010], Konwergencja dochodowa w krajach Unii Europejskiej, Wydawnictwo Naukowe Uniwersytetu Szczecińskiego, Szczecin.

Borsi, M.T., Metiu, N. [2013], The Evolution of Economic Convergence in the European Union, "Deutsche Bundesbank Discussion Paper", No. 28/2013.

IMF [2020], World Economic Outlook Database, October 2019 (updated January 2020), www. imf.org (10.02.2019).

Jóźwik, B. [2017], Realna konwergencja gospodarcza państw członkowskich Unii Europejskiej z Europy Środkowej i Wschodniej. Transformacja, integracja i polityka spójności, Wydawnictwo Naukowe PWN, Warsaw.

Liberda, Z.B. [2009], Konwergencja gospodarcza Polski, VIII Kongres Ekonomistów Polskich, Polskie Towarzystwo Ekonomiczne, Warsaw.

Malaga, K. [2004], Konwergencja gospodarcza $w$ krajach OECD $w$ świetle zagregowanych modeli wzrostu, Wydawnictwo Akademii Ekonomicznej, Poznań.

Mankiw, N.G., Romer, D., Weil D.N. [1992], A Contribution to the Empirics of Economic Growth, "Quarterly Journal of Economics", Vol. 107, pp. 407-437.

Matkowski, Z., Próchniak, M. [2013], Real Income Convergence, in: M.A. Weresa (ed.), Poland. Competitiveness Report 2013. National and Regional Dimension, SGH Publishing House, Warsaw, pp. 46-67.

Matkowski Z., Próchniak M., Rapacki R. [2016a], Income Convergence in Poland vis-à-vis the EU: Major Trends and Prospects, in: M.A. Weresa (ed.), Poland. Competitiveness Report 2016. The Role of Economic Policy and Institutions, SGH Publishing House, Warsaw, pp. 39-59.

Matkowski Z., Próchniak M., Rapacki R. [2016b], Real Income Convergence between Central Eastern and Western Europe: Past, Present, and Prospects, "Ekonomista", No. 6, pp. 853-892.

Michałek, J.J., Siwiński, W., Socha, M. [2007], Polska w Unii Europejskiej-dynamika konwergencji ekonomicznej, Wydawnictwo Naukowe PWN, Warsaw.

Monfort, M., Cuestas, J.C., Ordóñez, J. [2013], Real Convergence in Europe: A Cluster Analysis, "Economic Modelling", Vol. 33, pp. 689-694.

Mucha, M. [2012], Mechanizm dywergencji gospodarczej w strefie euro, "Ekonomista", No. 4, pp. 487-498.

Próchniak, M. [2017], Income Convergence Between the CEE Region and Western Europe, in: M.A. Weresa (ed.), Poland. Competitiveness Report 2017. Internationalization and Poland's Competitive Position, SGH Publishing House, Warsaw, pp. 31-43.

Próchniak, M. [2018], Convergence of Income Levels Between East-Central and Western Europe, in: M.A. Weresa, A.M. Kowalski (eds.), Poland. Competitiveness Report 2018. The Role of Cities in Creating Competitive Advantages, SGH Publishing House, Warsaw, pp. 31-43. 
Próchniak, M. [2019], Income Convergence of Poland to the Average EU Level, in: A.M. Kowalski, M.A. Weresa (eds.), Poland. Competitiveness Report 2019. International Competitiveness in the Context of Development of Industry 4.0, SGH Publishing House, Warsaw, pp. 89-102.

Próchniak, M et al.. [2019], Wyrównywanie luki w poziomie zamożności między Europa Środkowo-Wschodnia a Europa Zachodnia, in: M. Strojny (ed.), Europa Środkowo-Wschodnia wobec globalnych trendów: gospodarka, społeczeństwo i biznes, SGH Report for the $29^{\text {th }}$ Economic Forum in Krynica-Zdrój, SGH Warsaw School of Economics, Warsaw, pp. 13-43.

Próchniak, M., Witkowski, B. [2012], Real Economic Convergence and the Impact of Monetary Policy on Economic Growth of the EU Countries: The Analysis of Time Stability and the Identification of Major Turning Points Based on the Bayesian Methods, "National Bank of Poland Working Paper", No. 137.

Rapacki, R., Próchniak, M. [2012], Wzrost gospodarczy w krajach Europy Środkowo-Wschodniej na tle wybranych krajów wschodzących, "Gospodarka Narodowa”, No. 1-2, pp. 65-96.

Solow, R.M. [1956], A Contribution to the Theory of Economic Growth, "Quarterly Journal of Economics", Vol. 70, pp. 65-94.

Staňisić, N. [2012], The Effects of the Economic Crisis on Income Convergence in the European Union, "Acta Oeconomica", Vol. 62, pp. 161-182. 

Chapter 5

\section{Income Inequality and Poverty in Poland in 2010-2018}

Patrycja Graca-Gelert

\subsection{Introduction}

The literature offers various definitions of macroeconomic competitiveness, i.e. in the context of economies or regions. In the most popular publications dealing with the subject of the competitiveness of countries or regions, such as The Global Competitiveness Report or The EU Regional Competitiveness Index, definitions of competitiveness are embedded primarily in research on total factor productivity, whereas income inequality or the risk of poverty are omitted in designing competitiveness measures. In a word, competitiveness is viewed mainly as a purely economic notion. In the last 2-3 years, some more space has been devoted to social inclusion, income inequality or poverty in this context, but these issues are still tackled marginally, so to say (with the exception of some of the components of these measures relating to the labor market or education), and they do not stem directly from the definition of competitiveness.

This Report, as well as its previous editions (from as early as 2007), have directly emphasized the significance of one of the elements of the definition of competitiveness at country level, i.e. improvement of the living standard of the population, depending also on social inclusion which comprises elements such as social equality and minimization of the risk of poverty. On the one hand, (relatively high) income disparities can be viewed as a symptom of weak competitiveness of one country vis-á-vis others, as such an economy is unable to ensure sustainable growth to all its citizens, i.e. not everyone can equally benefit from economic growth. On the other hand (relatively large) income disparities can be treated as a determinant of worse competitiveness of an economy compared to other countries - many studies show a negative impact of income disparities and, basically, of increasing social exclusion, on economic growth [e.g., Ostry, Berg and Tsangarides, 2014] or economic and social welfare. In general,

12019 could not be included due to unavailability of data for that year. 
the correlation between the competitiveness of regions or economies and income inequality is strong and negative [Annoni and Djikstra, p. 26; Neagu and Teodoru, 2018].

As already mentioned, income inequality and risk of poverty measures have been omitted so far in designing many measures of competitiveness, focusing mainly on factors related to economic growth. Yet the perspective has now been shifting, as it becomes clear that developments such as rising income inequality, which can be witnessed in many regions around the world, contribute to undermining social cohesion, a growing sense of unfairness, perceived loss social identity and human dignity, erosion of trust in institutions and the social contract, and disenchantment with political processes [Schwab, 2019, p. IX]. Previous research focused on links between economic growth (effectiveness) and inequalities (justice) treated as a purely exchangeable relationship. It turns out, however, that omitting social or environmental protection issues leads to a lower economic growth or hinders the achievement of sustainable growth in the long term. This is why it is important to ensure that, apart from purely economic components of competitiveness, such as the already mentioned total factor productivity, welfare-determining social factors are taken into consideration, such as inequalities or the risk of poverty.

While, in general, a positive correlation can be seen to exist between the competitiveness of economies and inclusive development, productivity growth (main competitiveness factor) is not always accompanied by a decline in income inequality. In other words, according to the traditional definition, which disregards social inclusion, the growth of competitiveness does not necessarily lead to a reduced income inequality, although it is indeed strongly correlated with poverty reduction in absolute terms. Certain countries with a similar level of competitiveness can represent completely different scales of income disparity and social inclusion. From the point of view of social welfare, it is therefore important that, apart from efficiency improvement, one should not forget about a proportional participation of all income groups in the growth of overall income.

The study presented in this edition of the Report puts focus on the competitiveness of the service sector. While the notion of competitiveness at enterprise or country/ economy level has been described quite well in the literature, what poses a difficulty is defining competitiveness at the level of sectors of the economy, including also the service sector. This problem was already pointed out by Momaya in 1998 [Momaya, 1998] and it seems that sectoral competitiveness has been studied the least so far [European Commission, 2018]. Most concepts of competitiveness at the sector level relate to productivity and trade [European Commission, 2018; cf. Castellani and Koch, 2015], which are also key elements in defining economic competitiveness. Another problem in defining competitiveness at the sector level is that sectors are defined as 
sections of the economy or industries [cf. Momaya, 1998] rather than the division of the economy into agriculture, industry, and services. Moreover, even - or perhaps the more so - if a broad definition of the sector is taken into account, there are usually many heterogeneous goods produced in a country's service sector, among which we can distinguish those whose production/exchange is highly competitive and those that are completely uncompetitive. Such a complexity of analysis makes it additionally difficult to unambiguously assess the relationship between the competitiveness of the service sector and income inequality. The service sector is also highly diversified in terms of productivity growth in its individual parts [Wölfl, 2003]. For this reason, it is difficult to assess a priori, without an individual insight into a particular economy, or a particular service sector, how an increase in the competitiveness of a sector will translate into income inequality in that sector (of course, if competitiveness is viewed through the lens of productivity, which obviously does not exhaust the whole notion of service sector competitiveness). What is more, studies conducted so far show that the measurement of the competitiveness of the service sector is more problematic than the measurement of other sectors of the economy [De Fuentes et al., 2015], which poses an additional problem in the context of examiniting the relationship between the competitiveness of the service sector and income inequality.

It is also worth looking closer at the definition of sectoral competitiveness, quoting an example set of its defining indicators [European Commission, 2018], such as: productivity (e.g. labor p., TFP), trade competitiveness (e.g., RCA - revealed comparative advantage), price and cost competitiveness (e.g., real effective exchange rate, unit labor costs), innovation and technologies (e.g., share of small and medium-sized enterprises in product or process innovation implementation), business dynamics (e.g. share of businesses increasing employment very dynamically), global value chains (e.g. export share in value added creation). As a matter of fact, none of the sectoral competitiveness indicators mentioned above is a popular direct determinant described in the literature in the context of income inequality. Of course, these components could be linked to certain aspects (in the context of the service sector) of the Kuznets [Kuznets, 1955] or Hecksher-Ohlin theory, Industry 4.0, SBTC (skill-biased technological change), globalization, liberalization of trade and finance, which make direct reference to income inequality, but creation of a theory that explains direct links between the competitiveness of the service sector and income disparities is unlikely due to the multiplicity of factors that can have an impact on income inequality in this case, developing in various directions and with various (difficult to determine) intensities, and with various time patterns. Therefore, this chapter will limit itself to presentation of a general analysis of income inequality, poverty, and risk of poverty in Poland vis-à-vis the European Union as a competitiveness factor 
at country level, without showing relations with the competitiveness of the service sector. The only statement that could be ventured at this point is that increasing the competitiveness of the service sector contributes to boosting the competitiveness of the entire economy. This, in turn, is a significant driver of economic welfare, but it is not a sufficient condition from the social welfare perspective (or economic welfare in the context of normative analysis).

The main objective of the study presented in this chapter is to show the main tendencies in income inequality and the risk of poverty in Poland compared with other EU countries in 2010-2018. In addition, more space is devoted to an analysis of the structure of income inequality in Poland, decomposing income disparities into socio-economic groups, residence classes, regions, and showing the direct impact of the child support benefit under the "Family 500+" program on income inequality in Poland.

\subsection{Income Inequality and Poverty in Poland in $2010-2018$}

In order to illustrate income inequality, its structure, and poverty or risk of poverty in Poland in 2010-2018, a set of selected subject matter data has been used, which differ between themselves in many respects, such as the data source, income definition, measurement method, poverty line assumed, equivalence scale, or reference unit. One of the purposes of such a diversified data selection is to show how complex the measurement and interpretation of those phenomena is. The importance of those differences was emphasized many times in previous editions of the Report. For the purposes of the analysis presented in this part of the chapter, data from three sources has been used - household budget surveys (HBS) by GUS, EU-SILC (data provided by GUS, Eurostat methodology), and OECD. In the case of HBS data, these are both dispersion measures calculated directly by GUS and indicators calculated by the author of this chapter on the basis of individual non-identifiable data from HBS. This time, data descriptions together with main differences concerning the measures adopted are placed directly under the charts and tables presenting selected variables, and not in the text, as in previous editions of the Report.

When comparing the income inequality measures shown in Figure 5.1, it can be clearly seen that only data from EU-SILC shows a decrease in income inequality in 2018 compared to the previous period. In addition, the decline in income disparities has been accelerating for that data starting in 2014-2015. The level of inequality as measured by the Gini coefficient (EUROSTAT/EU-SILC) is also slightly lower compared to the GUS data (according to GUS calculations), which is due to a number of factors, of which taking into account benefits of scale for larger households (application of 
the equivalency scale) seems to be the most significant one. As can be seen, the use of the equivalence scale for HBS micro data (PGG GINI) brings income disparities closer to the value of the dispersion measure used for EU-SILC data (except the last year of analysis). The relations of the individual income deciles show that the aggravation of income inequality in 2018, according to HBS data, compared to 2017, occurred mainly in the lower parts of the distribution.

Figure 5.1. Income inequality in Poland in 2010-2018

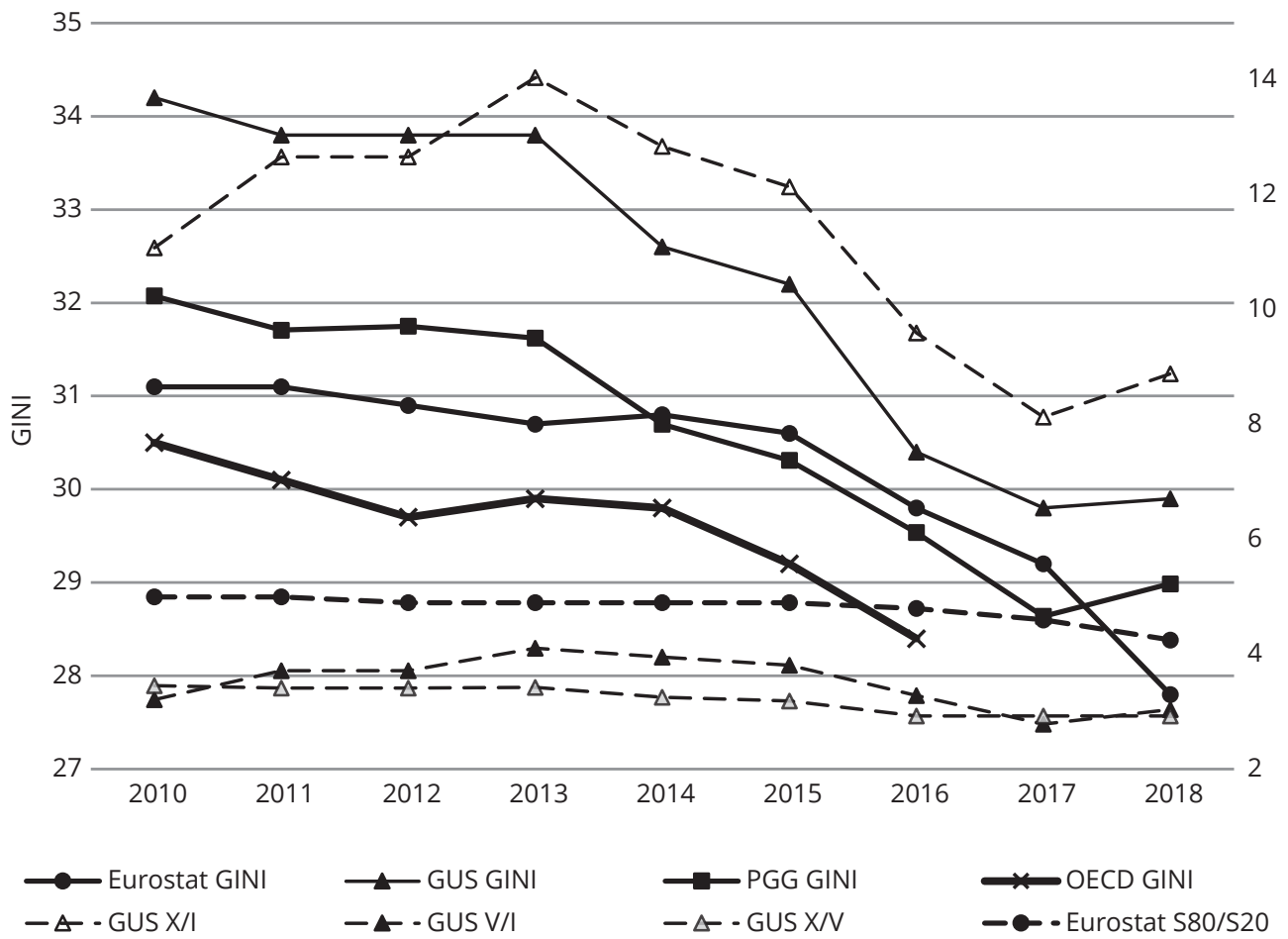

* Eurostat - equivalized disposable household income (modified OECD equivalence scale; the unit of reference is the person; the source is EU-SILC - data collected by GUS in accordance with Eurostat methodology); GUS - disposable household income (equivalence scale - none, per capita approach was adopted; the data source is HBS); PGG GINI - equivalized disposable household income (modified OECD equivalence scale; the unit of reference is the household; the data source is HBS); OECD GINI - equivalized disposable household income (square root equivalence scale, the unit of reference is the person). Dispersion measures used: Gini coefficient - takes into account income inequalities within the whole distribution, and its value ranges between $0(0 \%)$ for a perfectly equal income distribution and $1(100 \%)$ for an extremely unequal income distribution (the Gini coefficient is expressed here in \%); S80/S20 - quintile ratio index, representing the ratio of income of the $20 \%$ of the population with the highest income to that of the $20 \%$ of the population with the lowest income; X/I, V/I and X/V - income ratios of the 10th and 1st deciles, the 5th and 1st deciles, and the 10th and 5th deciles, respectively, of income distribution.

Source: Eurostat EU-SILC; GUS, 2019a, Tables 5 and 6, p. 338; OECD; own study based on GUS household budget surveys.

Figure 5.2 complements the picture of the evolution of income inequality in Poland: it shows another measure of dispersion closely related to the Gini coefficient - the 
Lorenz curve. Comparing the Lorentz curves for each year - 2010, 2014, and 2018 - it can be seen that a more pronounced change in income inequality (decrease) occurred between 2014 and 2018 than between 2010 and 2014, which is of course in line with the behavior of the GUS GINI variable in Figure 5.1.

Figure 5.2. Income inequalities* in Poland, Lorenz curves** for 2010, 2014 and 2018.

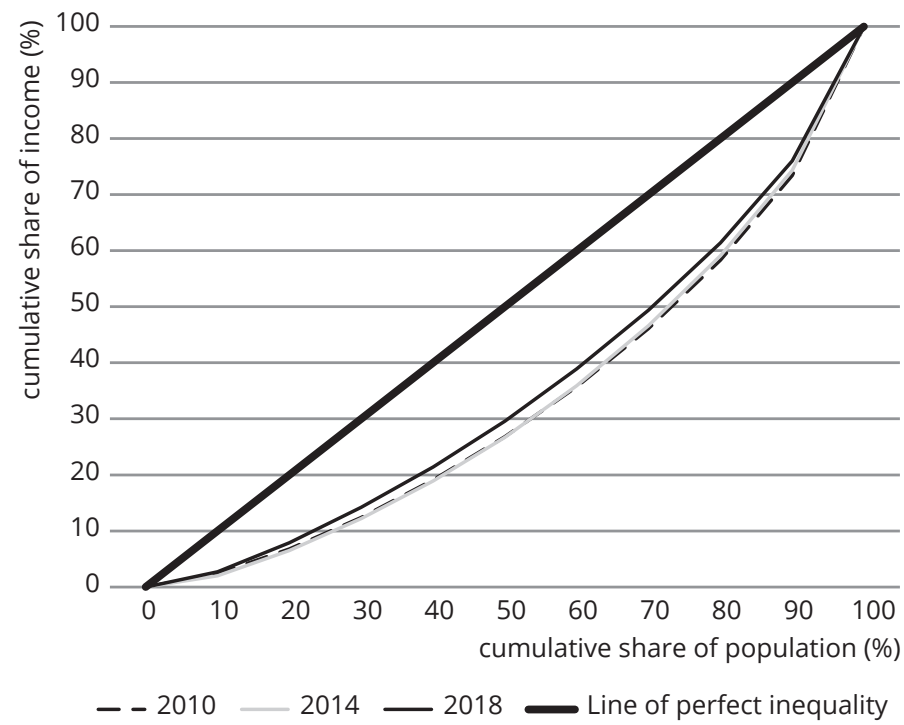

* Per capita disposable household income

** In very general terms, the more distant the Lorentz curve is from the line of perfect equality (i.e., the more convex it is), the greater the scale of income inequality.

Source: Own study based on data from: GUS, 2019a, Table 6, p. 338.

Apart from the scale of overall income inequality, it is also worth looking at its structure, which can be analyzed in many ways. In this part, the study was carried out at a fairly basic level, by decomposing income inequality according to the different characteristics of households - socio-economic groups, class of the place of residence, and the region of residence. The first step in looking more closely at the structure of inequality is to examine income inequality among households from individual socio-economic groups. Table 5.1 shows relevant GUS calculations, whereas Table 5.2 presents the results of the author's decomposition of income inequality into those groups. The measurement results in both tables may show some discrepancies (for the same income definitions and equivalence scale) due to slight differences in data adjustment. Secondly, in Table 5.2, income inequality was also decomposed with reference to another, additional definition of income and equivalence scale. Thirdly, the individual HBS data allowed greater disaggregation of socio-economic groups. 
According to data on intra-group differentiation, i.e. by socio-economic group, published by the CSO, from 2010 the largest and most volatile income inequalities were witnessed in the group of farmers, while the lowest and least variable income disparities were recorded among pensioners. Between 2010 and 2018, income disparities in all socio-economic groups decreased: most for workers and pensioners, and least for farmers, who continued to represent a higher degree of income inequality than one year before Poland's accession to the European Union. Throughout the period considered, income inequality in rural areas was greater than income disparities in cities, although 2018 saw convergence of income inequality between groups. Compared to the previous year, in 2018 income inequality increased in the self-employed and workers group, and in the other groups it decreased significantly, including farmers.

Table 5.1. Household income inequality* by socio-economic group and by place of residence (urban / rural) in Poland in 2010-2018

\begin{tabular}{|l|c|c|c|c|c|c|c|c|c|}
\hline \multicolumn{1}{|c|}{ Households } & 2010 & 2011 & 2012 & 2013 & 2014 & 2015 & 2016 & 2017 & 2018 \\
\hline Total & 34.2 & 33.8 & 33.8 & 33.8 & 32.6 & 32.2 & 30.4 & 29.8 & 29.9 \\
\hline Workers & 34.7 & 34.6 & 34.3 & 34.1 & 33.4 & 32.7 & 30.7 & 29.3 & 30.1 \\
\hline Farmers & 53.3 & 53.9 & 55.9 & 59.9 & 54.4 & 55.3 & 54.1 & 54.7 & 51.7 \\
\hline Self-employed & 37.5 & 37.3 & 38.2 & 37.4 & 37.8 & 37.3 & 34.6 & 34.0 & 35.5 \\
\hline Old-age pensioners & 24.9 & 24.4 & 24.2 & 23.9 & 23.6 & 23.3 & 22.4 & 22.3 & 22.2 \\
\hline Disability pensioners & 29.1 & 29.2 & 27.9 & 28 & 27.6 & 27.7 & 26.3 & 25.9 & 24.7 \\
\hline In cities & 32.3 & 31.7 & 31.7 & 31.2 & 30.6 & 30.3 & 28.8 & 28.1 & 28.3 \\
\hline In rural areas & 33.9 & 33.7 & 34.3 & 35.2 & 32.9 & 32.3 & 30.5 & 30.2 & 30 \\
\hline
\end{tabular}

${ }^{a}$ Per capita disposable household income (with the household as the unit of reference).

Source: GUS, 2019a, Table 5, p. 338.

Total income inequality depends not only on intra-group income inequality but also on disparities between different groups. For this reason, it is desirable to fully decompose income disparities by socio-economic groups. Since the main measure of dispersion relied on in this chapter is the Gini coefficient, the decomposition used will apply exactly to this measure, and its overall form can be written as follows [see, e.g., Deutsch and Silber, 1999; Bellú and Liberati 2006; Lambert and Aronson, 1993]2:

$$
I_{O}=I_{W}+I_{B}+I_{R}=G_{O}=\left(\sum_{k=1}^{K} P_{k} S_{k} G_{k}\right)+\left(\frac{2 \operatorname{cov}\left[y_{0}, F\left(y_{0}\right)\right]}{\mu_{0}}\right)+\left(G_{O}-\left[I_{W}+I_{B}\right]\right),
$$

\footnotetext{
2 The individual components of the above decomposition are described in greater detail in the 2018 Report. [Weresa and Kowalski (eds.), 2018].
} 
where $I_{0}$ is overall income inequality, $I_{W}$ means the contribution of intra-group inequalities to overall income inequality, $I_{B}$ determines the contribution of inter-group inequalities to overall income inequality, $I_{R}$ is the residual term, $G_{O}$ is the Gini coefficient for overall income, $K$ is the number of analyzed groups $(k=1, \ldots, K), P_{k}$ means the population share of group $k, S_{k}$ is the income share of group $k, G_{k}$ represents income inequality in group $k$ measured with the use of the Gini coefficient, $y_{0}$ is income, $\mu_{0}$ denotes average income, and $F\left(y_{0}\right)$ is the cumulative distribution of total income ${ }^{3}$. While the intra-group and the inter-group income inequality components do not pose major interpretation difficulties, it is worth looking more closely at the role of the residual term. It shows to what extent overall income inequality results from the overlap of the distributions of income. The more the income distributions of each group are disjoint (do not overlap), the smaller the value of this element will be, closer to 0 (which is obtained in the case of completely disjoint distributions of the analyzed groups). The term $I_{B}$ can be thought of as a component of inter-group net income inequality, and the sum $\left(I_{B}+I_{R}\right)$ as a component of inter-group gross income inequality.

The decomposition of the Gini coefficient by socio-economic group, as well as based on other criteria analyzed in the study presented in this chapter, was performed using individual non-identifiable data from household budget surveys (HBS) for two different income definitions of income and equivalence scale, with the DAD 4.6 program was used for calculations [J.Y. Duclos, A. Araar, C. Fortin, DAD: A Software for Distributive Analysis/Analyse Distributive, MIMAP programme, International Development Research Centre, Government of Canada and CIRPÉE, Université Laval].

The assessment of the income inequality structure in Poland was based not only on the results of inequality decomposition presented in this chapter but also on 2017 results to be found in last year's Report [Graca-Gelert, 2019]. As mentioned above, the inequality decomposition by socio-economic group was carried out with reference to two definitions of income and scale of equivalence, and two levels of population disaggregation by socio-economic group. However, the characteristics of the results of the analysis were limited to the common characteristics of the individual decompositions.

Regardless of the definition and grouping, 2017-2018 saw an increase in the importance of intra-group inequalities and a decrease in the role of inter-group disparities

3 It is worth adding that not all dispersion measures decompose into three components. Sometimes, this concerns only two components - intra-group and inter-group inequality. Thus, in terms of decomposition, the Gini coefficient may be not the easiest indicator to interpret, but the choice of this tool for the purposes of this study arises, among other things, from the fact that it is most commonly applied in research on income inequality and allows benchmarking of a numerous group of countries due to its popularity. The Gini coefficient was also used to analyze income inequality in all EU member states in a study described in the next part of this chapter. 
in explaining income inequality in Poland - in general, in terms of both net and gross inter-group inequalities. In the case of equivalized disposable household income, the importance of inter-group inequalities is clearly greater and each of the three terms of decomposition - intra-group, net inter-group and residual - accounts here for about $1 / 3$ of income inequality in Poland (in the case of a smaller number of subgroups; the greater their number, the smaller the role of the intra-group term). The second most evident change in the structure of income inequality was the increase in the importance of inequality among workers (increase in inequality and share of income, mainly in the sub-group of non-manual workers) and pensioners (decrease in inequality and increase in the share of population and in total income) in explaining income disparities in Poland.

Table 5.2. Decomposition of the Gini coefficient by socio-economic group and sub-group (in accordance with GUS definition) in Poland in 2018

\begin{tabular}{|c|c|c|c|c|c|c|}
\hline Group & 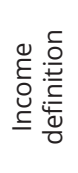 & 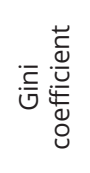 & 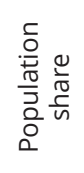 & 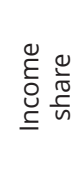 & 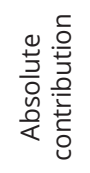 & 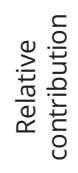 \\
\hline Workers & \multirow{19}{*}{ 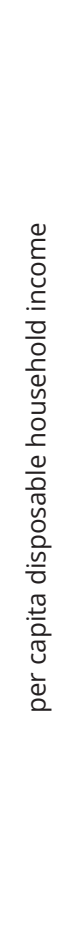 } & 0.304 & 0.502 & 0.521 & 0.079 & 0.266 \\
\hline Farmers & & 0.519 & 0.037 & 0.036 & 0.001 & 0.002 \\
\hline Self-employed & & 0.355 & 0.072 & 0.089 & 0.002 & 0.008 \\
\hline Pensioners & & 0.224 & 0.349 & 0.330 & 0.026 & 0.086 \\
\hline Living on unearned sources & & 0.370 & 0.039 & 0.025 & 0.000 & 0.001 \\
\hline Intra-group inequalities & & - & - & - & 0.109 & 0.363 \\
\hline Inter-group inequalities & & - & - & - & 0.046 & 0.154 \\
\hline Residual term & & - & - & - & 0.144 & 0.483 \\
\hline Manual workers & & 0.247 & 0.238 & 0.196 & 0.012 & 0.039 \\
\hline Non-manual workers & & 0.310 & 0.265 & 0.325 & 0.027 & 0.089 \\
\hline Farmers & & 0.519 & 0.037 & 0.036 & 0.001 & 0.002 \\
\hline Self-employed & & 0.355 & 0.072 & 0.089 & 0.002 & 0.008 \\
\hline Old-age pensioners & & 0.219 & 0.298 & 0.288 & 0.019 & 0.063 \\
\hline Disability pensioners & & 0.242 & 0.051 & 0.041 & 0.001 & 0.002 \\
\hline Living on social benefits & & 0.258 & 0.024 & 0.012 & 0.000 & 0.000 \\
\hline Living on other unearned sources & & 0.410 & 0.014 & 0.013 & 0.000 & 0.000 \\
\hline Intra-group inequalities & & - & - & - & 0.061 & 0.203 \\
\hline Inter-group inequalities & & - & - & - & 0.097 & 0.326 \\
\hline Residual term & & - & - & - & 0.141 & 0.471 \\
\hline
\end{tabular}


cont. tab 5.2

\begin{tabular}{|c|c|c|c|c|c|c|}
\hline Group & 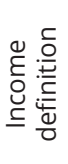 & 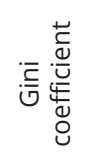 & 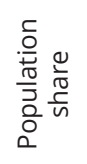 & 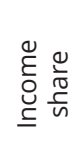 & 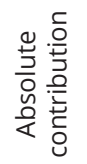 & 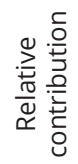 \\
\hline Workers & \multirow{19}{*}{ 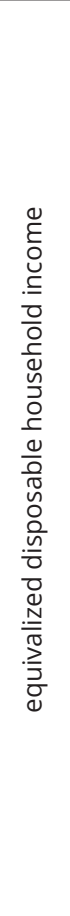 } & 0.261 & 0.502 & 0.556 & 0.073 & 0.252 \\
\hline Farmers & & 0.514 & 0.037 & 0.042 & 0.001 & 0.003 \\
\hline Self-employed & & 0.316 & 0.072 & 0.097 & 0.002 & 0.008 \\
\hline Pensioners & & 0.231 & 0.349 & 0.280 & 0.023 & 0.078 \\
\hline Living on unearned sources & & 0.344 & 0.039 & 0.025 & 0.000 & 0.001 \\
\hline Intra-group inequalities & & - & - & - & 0.099 & 0.341 \\
\hline Inter-group inequalities & & - & - & - & 0.095 & 0.326 \\
\hline Residual term & & - & - & - & 0.096 & 0.332 \\
\hline Manual workers & & 0.208 & 0.238 & 0.218 & 0.011 & 0.037 \\
\hline Non-manual workers & & 0.272 & 0.265 & 0.337 & 0.024 & 0.084 \\
\hline Farmers & & 0.514 & 0.037 & 0.042 & 0.001 & 0.003 \\
\hline Self-employed & & 0.316 & 0.072 & 0.097 & 0.002 & 0.008 \\
\hline Old-age pensioners & & 0.227 & 0.298 & 0.247 & 0.017 & 0.058 \\
\hline Disability pensioners & & 0.221 & 0.051 & 0.033 & 0.000 & 0.001 \\
\hline Living on social benefits & & 0.290 & 0.024 & 0.014 & 0.000 & 0.000 \\
\hline Living on other unearned sources & & 0.396 & 0.014 & 0.011 & 0.000 & 0.000 \\
\hline Intra-group inequalities & & - & - & - & 0.055 & 0.191 \\
\hline Inter-group inequalities & & - & - & - & 0.123 & 0.425 \\
\hline Residual term & & - & - & - & 0.111 & 0.383 \\
\hline
\end{tabular}

a In the case of per capita disposable income, the Gini coefficient values for individual socio-economic groups are, firstly, expressed not as percentages (as, e.g., in Table 5.1.), but as decimal fractions and, secondly, may differ slightly from the values provided in Table 5.1 owing to a somewhat different method of data adjustment for the study.

Source: Own study based on GUS household budget surveys.

Changes of lesser significance in these years involved an increase in income inequality in the population group living on unearned sources, despite a decrease in the group's share of both the population and total income, and a decrease in the value of the Gini coefficient for income received by farmers and a decrease in their share of the population and total income. In 2018, the biggest contribution to explaining income inequality (intra-group term) in Poland was made by the group of workers and pensioners (due to its large share of the population and total income), and the smallest - by those living on unearned sources and farmers.

As regard the decomposition of the Gini coefficient by size of place of residence, no particularly big changes were reported compared to the previous year (cf. previous edition of the Report). It can only be unambiguously concluded that income inequality increased slightly in almost all residence classes. As in the previous year, in 2018 
the weight of the residual term in explaining overall income inequality was quite high or, to put it differently, inequalities due to the place of residence (in gross terms, i.e. for the sum of the inter-group terms and the residual term) had a definitely greater effect on income disparities than intra-group inequalities. In the case of the latter category, what mainly accounted for income disparities was income inequality in rural areas - mainly due to their high share in total population and in total income. The greatest income inequalities were reported for the largest cities, with a population of more than 500,000 and in rural areas.

Table 5.3. Decomposition of the Gini coefficient by size of place of residence of households in Poland in 2018

\begin{tabular}{|c|c|c|c|c|c|c|}
\hline Group & 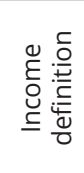 & 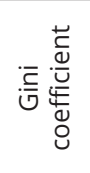 & 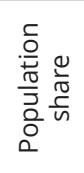 & 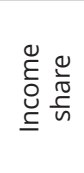 & 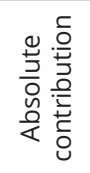 & 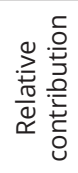 \\
\hline Population of $500 \mathrm{k}$ and more & \multirow{9}{*}{ 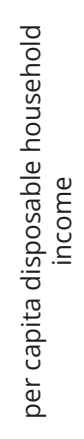 } & 0.313 & 0.146 & 0.200 & 0.009 & 0.031 \\
\hline Population of $200-499 k$ & & 0.279 & 0.099 & 0.112 & 0.003 & 0.010 \\
\hline Population of $100-199 k$ & & 0.262 & 0.095 & 0.098 & 0.002 & 0.008 \\
\hline Population of $20-99 \mathrm{k}$ & & 0.258 & 0.206 & 0.202 & 0.011 & 0.036 \\
\hline Population of less than $20 \mathrm{k}$ & & 0.257 & 0.129 & 0.119 & 0.004 & 0.013 \\
\hline Rural areas & & 0.302 & 0.326 & 0.270 & 0.027 & 0.089 \\
\hline Intra-group inequalities & & - & - & - & 0.056 & 0.187 \\
\hline Inter-group inequalities & & - & - & - & 0.095 & 0.319 \\
\hline Residual term & & - & - & - & 0.148 & 0.494 \\
\hline Population of $500 \mathrm{k}$ and more & \multirow{9}{*}{ 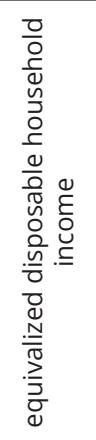 } & 0.311 & 0.146 & 0.189 & 0.009 & 0.030 \\
\hline Population of $200-499 k$ & & 0.273 & 0.099 & 0.108 & 0.003 & 0.010 \\
\hline Population of $100-199 k$ & & 0.252 & 0.095 & 0.095 & 0.002 & 0.008 \\
\hline Population of $20-99 k$ & & 0.255 & 0.206 & 0.199 & 0.010 & 0.036 \\
\hline Population of less than $20 \mathrm{k}$ & & 0.253 & 0.129 & 0.120 & 0.004 & 0.013 \\
\hline Rural areas & & 0.303 & 0.326 & 0.289 & 0.029 & 0.098 \\
\hline Intra-group inequalities & & - & - & - & 0.057 & 0.195 \\
\hline Inter-group inequalities & & - & - & - & 0.069 & 0.237 \\
\hline Residual term & & - & - & - & 0.164 & 0.567 \\
\hline
\end{tabular}

Source: Ibidem.

In the case of the decomposition of the Gini coefficient by region, a comparison of the situation between 2017 and 2018 (cf. previous edition of the Report) has proved somewhat difficult due to the fact that during that time some changes took place in the territorial division (see description under Table 5.4) involving three macroregions: 
the Central, Eastern and a new macroregion - the Mazowieckie voivodeship. Anyway, in 2018, no significant changes in the structure of income inequality were observed in relation to the previous year for those macroregions whose territory had not changed.

Table 5.4. Decomposition of the Gini coefficient by regiona of residence of households in Poland in 2018

\begin{tabular}{|c|c|c|c|c|c|c|}
\hline Group & 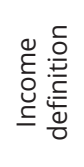 & 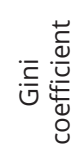 & 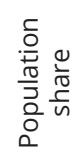 & 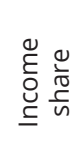 & 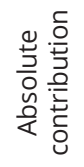 & 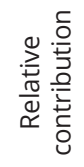 \\
\hline Southern macroregion & \multirow{10}{*}{ 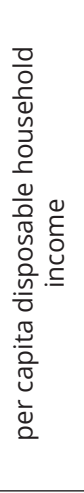 } & 0.265 & 0.208 & 0.209 & 0.012 & 0.039 \\
\hline North-Western macroregion & & 0.271 & 0.156 & 0.152 & 0.006 & 0.021 \\
\hline South-Western macroregion & & 0.289 & 0.106 & 0.106 & 0.003 & 0.011 \\
\hline Northern macroregion & & 0.309 & 0.146 & 0.142 & 0.006 & 0.021 \\
\hline Central macroregion & & 0.275 & 0.100 & 0.093 & 0.003 & 0.009 \\
\hline Eastern macroregion & & 0.282 & 0.134 & 0.116 & 0.004 & 0.015 \\
\hline Mazowieckie macroregion & & 0.360 & 0.150 & 0.182 & 0.010 & 0.033 \\
\hline Intra-group inequalities & & - & - & - & 0.044 & 0.148 \\
\hline Inter-group inequalities & & - & - & - & 0.050 & 0.168 \\
\hline Residual term & & - & - & - & 0.204 & 0.683 \\
\hline Southern macroregion & \multirow{10}{*}{ 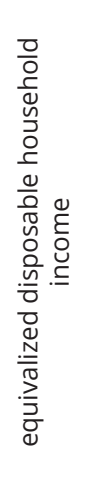 } & 0.250 & 0.208 & 0.210 & 0.011 & 0.038 \\
\hline North-Western macroregion & & 0.264 & 0.156 & 0.154 & 0.006 & 0.022 \\
\hline South-Western macroregion & & 0.288 & 0.106 & 0.105 & 0.003 & 0.011 \\
\hline Northern macroregion & & 0.299 & 0.146 & 0.143 & 0.006 & 0.021 \\
\hline Central macroregion & & 0.266 & 0.100 & 0.091 & 0.002 & 0.008 \\
\hline Eastern macroregion & & 0.275 & 0.134 & 0.116 & 0.004 & 0.015 \\
\hline Mazowieckie macroregion & & 0.352 & 0.150 & 0.180 & 0.010 & 0.033 \\
\hline Intra-group inequalities & & - & - & - & 0.043 & 0.148 \\
\hline Inter-group inequalities & & - & - & - & 0.049 & 0.170 \\
\hline Residual term & & - & - & - & 0.198 & 0.682 \\
\hline
\end{tabular}

* A change of division from 6 to 7 regions was adopted in 2018. Until the end of 2017, the division into the following macoregions (NUTS 1) applied: Central region - Mazowieckie and Łódzkie voivodships; Southern region - Śląskie and Małopolskie voivodships; Eastern region- Podlaskie, Lubelskie, Świętokrzyskie and Podkarpackie voivodships; North-Western region - Zachodniopomorskie, Lubuskie and Wielkopolskie voivodships; South-Western region - Dolnośląskie and Opolskie voivodships; Southern region - Pomorskie, Kujawsko-Pomorskie and Warmińsko-Mazurskie voivodships. Division applicable since 2018: Central region - Łódzkie and Świętokrzyskie voivodships; Southern region - Śląskie and Małopolskie voivodships; Eastern region- Podlaskie, Lubelskie and Podkarpackie voivodships; North-Western region - Zachodniopomorskie, Lubuskie and Wielkopolskie voivodships; South-Western region - Dolnośląskie and Opolskie voivodships; Southern region - Pomorskie, Kujawsko-Pomorskie and Warmińsko-Mazurskie voivodships; (new) Mazowieckie region - Mazowieckie regional and Warsaw capital subregion.

Source: Ibidem. 
Income inequality in the Central region decreased significantly due to the exclusion from it of the Mazowieckie voivodeship, which is now the macroregion with the highest income inequality. The role of the intra-group component in explaining overall income inequality also decreased significantly due to an increase in the number of groups (from 6 to 7). Among all macroregions, the Southern and Mazowieckie macroregions had the greatest effect on explaining income disparities in Poland, mainly due to their high share of population and total income. The South-Western and Eastern macroregions, on the other hand, had the least effect.

As in previous two editions of the Report, an estimation was made of the impact of the "Family 500+" on income inequality in Poland in 2018, and the results of the calculations were compared with the results from previous years in Table 5.5. Estimates of effect of the " $500+$ " benefit were made without taking into account a counterfactual scenario, i.e. ignoring a change in economic stimuli resulting from the introduction of the child support benefit. In a word, the decomposition presented below shows a difference between actual income and income excluding the child support benefit. The study was made on the basis of the same data source and with the use of the DAD 4.6 program, which was employed in the case of the decompositions referred to above. What represents a significant difference, however, is the use of a different method of decomposition of the Gini coefficient, as previous decompositions concerned an analysis taking into account a breakdown into groups, and in the present case assessment is to concern income sources. Therefore, the decomposition method by Lerman and Yitzhaki [1985] has been used in the following form:

$$
\left\{\begin{array}{l}
G_{0}=\frac{2 \sum_{k=1}^{K} \operatorname{cov}\left[y_{k}, F\left(y_{0}\right)\right]}{\mu_{0}}= \\
=\sum_{k=1}^{K}\left(\frac{\operatorname{cov}\left[y_{k}, F\left(y_{0}\right)\right]}{\operatorname{cov}\left[y_{k}, F\left(y_{k}\right)\right]}\right)\left(\frac{2 \operatorname{cov}\left[y_{k}, F\left(y_{k}\right)\right]}{\mu_{k}}\right)\left(\frac{\mu_{k}}{\mu_{0}}\right)= \\
=\sum_{k=1}^{K} R_{k} G_{k} S_{k}
\end{array}\right.
$$

where $G_{0}$ is the Gini coefficient for household income, and $y_{0}, \mu_{0}$ and $F\left(y_{0}\right)$ mean household income, average household income and the cumulative distribution of overall household income, respectively. There are $K$ components of household income, $y_{0}=\sum_{k=1}^{K} y_{k}$, where $y_{1}, \ldots, y_{k}$ are components of income, $S_{k}$ is the share of the $k$-th component of total household income, $G_{k}$ is the Gini coefficient for the $k$-th component 
of household income, and $R k$ is the Gini correlation of the k-th component with overall income. The product of $G_{k}$ and $R_{k}$ is interpreted as the concentration coefficient for the $k$-th component of income, sometimes referred to as pseudo-Gini.

Marginal effects of the change of the following income components on overall income inequality have been calculated as follows [Stark, Taylor and Yitzhaki, 1986]:

$$
\frac{\partial G_{0} / \partial e_{k}}{G_{0}}=\frac{S_{k} R_{k} G_{k}}{G_{0}}-S_{k},
$$

assuming an exogenous change in each household income coming from the $k$-th component of income equal to $e_{k} y_{k}$, with $e_{k}$ close to 1 .

Table 5.5. Decomposition of the Gini coefficient by child support benefit (500+) and other income in Poland in 2016-2018

\begin{tabular}{|c|c|c|c|c|c|c|c|c|}
\hline \multicolumn{2}{|c|}{ Source of income } & 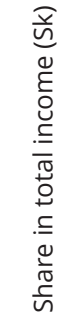 & 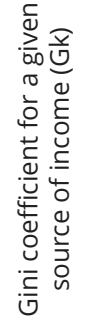 & 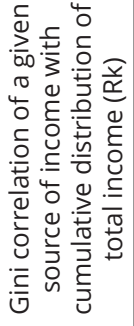 & 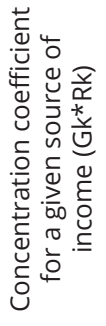 & 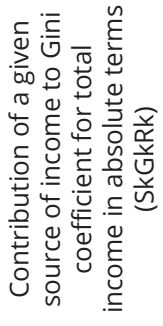 & 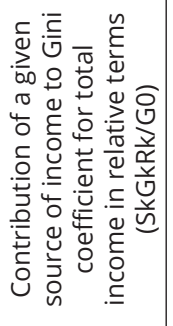 & 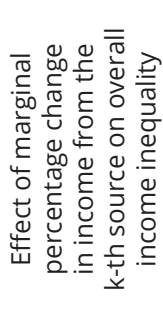 \\
\hline \multirow{3}{*}{$\begin{array}{l}\text { Disposable } \\
\text { income per } \\
\text { capita }\end{array}$} & 2016 & 1 & 0.304 & 1 & 0.304 & 1 & 1 & 0 \\
\hline & 2017 & 1 & 0.297 & 1 & 0.297 & 1 & 1 & 0 \\
\hline & 2018 & 1 & 0.299 & 1 & 0.299 & 1 & 1 & 0 \\
\hline \multirow{3}{*}{$\begin{array}{l}\text { Disposable } \\
\text { income - child } \\
\text { support benefit } \\
\text { (per capita) }\end{array}$} & 2016 & 0.985 & 0.315 & 0.996 & 0.314 & 0.309 & 1.019 & 0.033 \\
\hline & 2017 & 0.976 & 0.315 & 0.996 & 0.313 & 0.306 & 1.032 & 0.056 \\
\hline & 2018 & 0.979 & 0.315 & 0.996 & 0.314 & 0.308 & 1.030 & 0.051 \\
\hline \multirow{3}{*}{$\begin{array}{l}\text { Child support } \\
\text { benefit, per } \\
\text { capita }\end{array}$} & 2016 & 0.015 & 0.903 & -0.420 & -0.379 & -0.006 & -0.019 & -0.034 \\
\hline & 2017 & 0.024 & 0.823 & -0.491 & -0.404 & -0.010 & -0.032 & -0.056 \\
\hline & 2018 & 0.021 & 0.827 & -0.502 & -0.415 & -0.009 & -0.030 & -0.051 \\
\hline \multirow{3}{*}{$\begin{array}{l}\text { Available income } \\
\text { per equivalent } \\
\text { unit* }\end{array}$} & 2016 & 1 & 0.295 & 1 & 0.295 & 1 & 1 & 0 \\
\hline & 2017 & 1 & 0.286 & 1 & 0.286 & 1 & 1 & 0 \\
\hline & 2018 & 1 & 0.290 & 1 & 0.290 & 1 & 1 & 0 \\
\hline \multirow{3}{*}{$\begin{array}{l}\text { Available income } \\
\text { - child support } \\
\text { benefit (per } \\
\text { equivalent unit) }\end{array}$} & 2016 & 0.982 & 0.307 & 0.993 & 0.304 & 0.299 & 1.013 & 0.030 \\
\hline & 2017 & 0.967 & 0.299 & 0.995 & 0.298 & 0.288 & 1.006 & 0.039 \\
\hline & 2018 & 0.970 & 0.304 & 0.990 & 0.300 & 0.291 & 1.006 & 0.036 \\
\hline \multirow{3}{*}{$\begin{array}{l}\text { Child support } \\
\text { benefit per } \\
\text { equivalent unit }\end{array}$} & 2016 & 0.018 & 0.906 & -0.233 & -0.211 & -0.004 & -0.013 & -0.031 \\
\hline & 2017 & 0.033 & 0.828 & -0.059 & -0.049 & -0.002 & -0.006 & -0.039 \\
\hline & 2018 & 0.030 & 0.832 & -0.071 & -0.059 & -0.002 & -0.006 & -0.036 \\
\hline
\end{tabular}

${ }^{a}$ The modified OECD equivalence scale was used.

Source: Ibidem. 
Figure 5.3. Poverty and the risk of poverty for different poverty lines* in Poland, 2010-2018

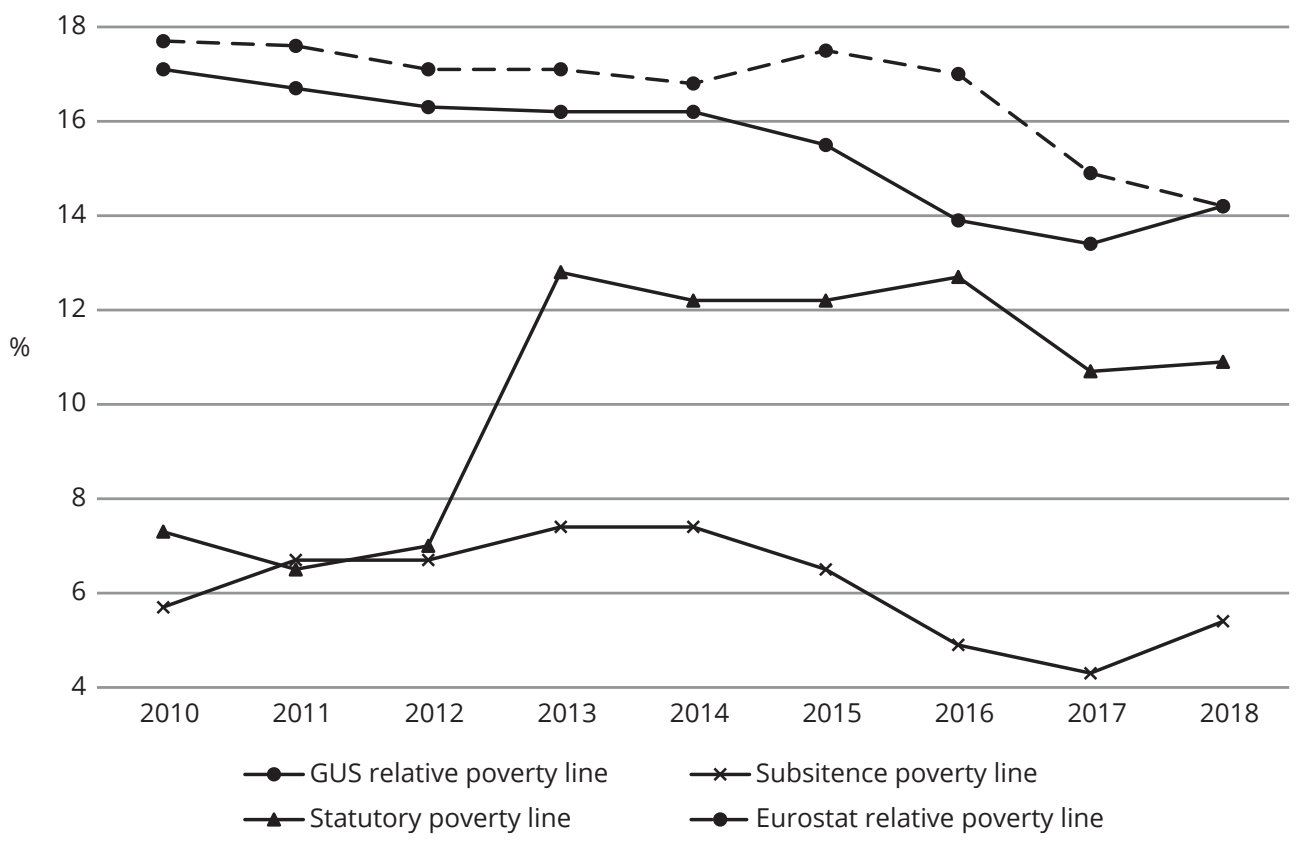

${ }^{a}$ In the case of the extreme poverty rate, a poverty line has been used, calculated on the basis of the subsistence minimum (estimated by the Institute of Labor and Social Affairs). The threshold takes into account only those needs that cannot be deferred, and consumption below this level leads to biological deprivation. The statutory poverty line is the amount which, in accordance with applicable Act on Social Assistance, entitles one to apply for a social assistance cash benefit. The relative poverty line is set at $50 \%$ of the mean monthly household expenditure calculated on the basis of the household budget surveys [GUS, 2018, p. 1]. The Eurostat at-risk-of-poverty rate taken into account in the chart is calculated on the basis of the poverty line set at $60 \%$ of median equivalized disposable income, based on EU-SILC data. Source: Eurostat; GUS, 2019b, Chart 1, p. 1.

According to Table 5.5, exclusion of the " $500+$ " child support benefit from total income would result in income inequality being higher by $1.6 \mathrm{pp}$ or $1.4 \mathrm{pp}$ rates in the case disposable income per capita and equivalized disposable income, respectively. The smallest role of the " $500+$ " benefit in reducing income inequality was witnessed in 2016, mainly because the program did not take effect until 1 April of that year. Its impact increased in 2017 and decreased slightly in 2018. Irrespective of the year under analysis, the "500+" benefit had an absolutely negative effect on income inequality in Poland, as testified by the negative values (of the "500+" benefit) in the last column of Table 5.5. Compared to 2017, inequalities in the benefit itself increased slightly in 2018, and the benefit and the total income cumulative distribution function were more negatively correlated, i.e. the " 500 +" benefit" applied to a greater extent to lower-income households However, these were slight differences. 
Based on an analysis of GUS data, it can be concluded that certain disturbing tendencies arose in 2018, related to the pattern of poverty or risk of poverty in Poland. Despite the introduction of the " $500+$ " child support benefit, which, according to GUS and many economic research centers, has contributed to the reduction of poverty and the risk of poverty (especially among children), the indicators for this phenomenon deteriorated in 2018, when the extreme poverty rate increased most markedly, from $4.3 \%$ to $5.4 \%$. The households most at risk of poverty were those living mainly on social benefits (other than pensions) and households with children [GUS, 2019b]. To some extent, which somewhat mitigates the assessment of the apparent increase in poverty rates, the increase in poverty in 2018 was due to a relatively significant increase in poverty thresholds [GUS, 2019b], but this does not apply to the whole scale of the phenomenon. The GUS relative poverty rate of the GUS also showed a certain increase in the risk of poverty, and in this case there is no indexation of the poverty threshold. The only metric that indicated a further decrease in the risk of poverty in 2018 compared to previous years was the at-risk-of-poverty rate as defined by Eurostat, based on EU-SILC data.

\subsection{Income Inequality and Poverty Risk in Poland Compared with Other EU Countries in 2010-2018}

In 2018 income inequality measured by the Gini coefficient fell in individual EU member states between 20.9\% (Slovakia) and 39.6\% (Bulgaria). By comparison, in 2017, it ranged between $23.2 \%$ and $40.2 \%$ for the same countries. The average for the whole European Union, measured as an average for all EU member states, weighted by population of each country was $0.3 \mathrm{pp}$ higher in 2018 than in 2017, at 30.9\%. As in previous years, the countries with the lowest income inequality included: Slovakia (20.9\%), Slovenia (23,4\%), and Czech Republic (24\%), whereas in Bulgaria (39.6\%), Lithuania (36.9\%), and Latvia (35.6\%) income inequality was the highest. The countries with the highest income, in both absolute and relative terms, in 2018 compared with 2017 were: Luxembourg ( $2.3 \mathrm{pp}$ and just under 7.5\%, respectively), Germany (2 pp and nearly $7 \%$, respectively), and Romania ( 2 pp and approx. $6 \%$, respectively). In contrast, the greatest decline in income inequality was reported in Slovakia (2.3 pp and almost 10\%, respectively), Ireland (1.7 pp and approx. 5.5\%, respectively), and Cyprus (1.7 pp and approx. 5.5, respectively). Poland, compared with other EU member states, saw a moderate income inequality at $27.8 \%$, slightly lower than the UE average. According to EU-SILC data, Poland showed a decrease in income inequality for another year in succession, this time by $1.4 \mathrm{pp}$ (nearly $5 \%$ ). 
Table 5.6. Income inequality* in Poland compared with other EU countries in $2010-2018^{* *}$

\begin{tabular}{|c|c|c|c|c|c|c|c|c|c|}
\hline \multirow[b]{2}{*}{ Country/Region } & 2010 & 2014 & 2017 & 2018 & \multicolumn{5}{|c|}{2018} \\
\hline & \multicolumn{4}{|c|}{$\begin{array}{c}\text { Gini coefficient (\%) after } \\
\text { social transfers }\end{array}$} & $\begin{array}{l}\text { Gini coefficient } \\
(\%) \text { before } \\
\text { social transfers } \\
\text { (excluding } \\
\text { pensions) }\end{array}$ & $\begin{array}{l}\text { Gini coefficient } \\
\text { (\%) before } \\
\text { social transfers } \\
\text { (including } \\
\text { pensions) }\end{array}$ & $\begin{array}{l}\mathrm{S} 80 / \\
\mathrm{S} 20\end{array}$ & $\begin{array}{l}\mathrm{S} 80 / \\
\mathrm{S} 50\end{array}$ & $\begin{array}{l}\mathrm{S} 50 / \\
\mathrm{S} 20\end{array}$ \\
\hline Slovakia & 25.9 & 26.1 & 23.2 & 20.9 & 24.3 & 37.2 & 3.03 & 1.62 & 1.87 \\
\hline Slovenia & 23.8 & 25.0 & 23.7 & 23.4 & 28.8 & 42.5 & 3.38 & 1.79 & 1.88 \\
\hline Czech Republic & 24.9 & 25.1 & 24.5 & 24.0 & 27.3 & 42.4 & 3.32 & 1.91 & 1.74 \\
\hline Belgium & 26.6 & 25.9 & 26.0 & 25.6 & 32.3 & 46.9 & 3.78 & 1.83 & 2.05 \\
\hline Finland & 25.4 & 25.6 & 25.3 & 25.9 & 34.4 & 48.8 & 3.65 & 2.00 & 1.82 \\
\hline Austria & 28.3 & 27.6 & 27.9 & 26.8 & 32.9 & 46.3 & 4.04 & 1.97 & 2.04 \\
\hline Sweden & 25.5 & 26.9 & 28.0 & 27.0 & 35.7 & 57.1 & 4.13 & 1.92 & 2.15 \\
\hline Netherlands & 25.5 & 26.2 & 27.1 & 27.4 & 32.7 & 46.6 & 4.05 & 2.03 & 2.00 \\
\hline Denmark & 26.9 & 27.7 & 27.6 & 27.8 & 36.0 & 49.0 & 4.11 & 2.07 & 1.99 \\
\hline Poland & 31.1 & 30.8 & 29.2 & 27.8 & 32.7 & 46.3 & 4.25 & 2.04 & 2.08 \\
\hline France & 29.8 & 29.2 & 28.8 & 28.5 & 34.9 & 50.9 & 4.23 & 2.15 & 1.97 \\
\hline Hungary & 24.1 & 28.6 & 28.1 & 28.7 & 34.1 & 49.1 & 4.35 & 2.12 & 2.04 \\
\hline Malta & 28.6 & 27.7 & 28.2 & 28.7 & 32.1 & 44.0 & 4.28 & 2.11 & 2.01 \\
\hline Ireland & 30.7 & 31.1 & 30.6 & 28.9 & 39.3 & 47.6 & 4.23 & 2.16 & 1.96 \\
\hline Cyprus & 30.1 & 34.8 & 30.8 & 29.1 & 34.0 & 47.6 & 4.29 & 2.19 & 1.95 \\
\hline Croatia & 31.6 & 30.2 & 29.9 & 29.7 & 33.8 & 49.8 & 5.00 & 2.03 & 2.46 \\
\hline Estonia & 31.3 & 35.6 & 31.6 & 30.6 & 34.1 & 44.1 & 5.07 & 2.11 & 2.40 \\
\hline EU & 30.5 & 31.0 & 30.6 & 30.9 & 36.0 & 51.2 & 5.17 & 2.22 & 2.31 \\
\hline Germany & 29.3 & 30.7 & 29.1 & 31.1 & 36.6 & 56.4 & 5.07 & 2.22 & 2.28 \\
\hline Portugal & 33.7 & 34.5 & 33.5 & 32.1 & 35.2 & 56.5 & 5.22 & 2.37 & 2.20 \\
\hline Greece & 32.9 & 34.5 & 33.4 & 32.3 & 35.2 & 57.0 & 5.51 & 2.26 & 2.43 \\
\hline Spain & 33.5 & 34.7 & 34.1 & 33.2 & 37.0 & 48.7 & 6.03 & 2.27 & 2.65 \\
\hline Luxembourg & 27.9 & 28.7 & 30.9 & 33.2 & 38.1 & 51.9 & 5.72 & 2.40 & 2.37 \\
\hline Italy & 31.7 & 32.4 & 32.7 & 33.4 & 35.7 & 48.5 & 6.09 & 2.28 & 2.67 \\
\hline United Kingdom & 32.9 & 31.6 & 33.1 & 34.2 & 41.2 & 54.6 & 5.95 & 2.47 & 2.41 \\
\hline Romania & 33.5 & 35.0 & 33.1 & 35.1 & 38.0 & 54.6 & 7.21 & 2.33 & 3.10 \\
\hline Latvia & 35.9 & 35.5 & 34.5 & 35.6 & 38.2 & 48.1 & 6.78 & 2.47 & 2.73 \\
\hline Lithuania & 37.0 & 35.0 & 37.6 & 36.9 & 40.6 & 51.1 & 7.09 & 2.62 & 2.69 \\
\hline Bulgaria & 33.2 & 35.4 & 40.2 & 39.6 & 43.3 & 54.8 & 7.66 & 2.95 & 2.59 \\
\hline
\end{tabular}

* Disposable income per equivalent unit. ${ }^{* *}$ Countries in the table are ranked according to ascending income inequality measured by the Gini coefficient after social transfers in 2018.

Source: Eurostat EU-SILC, https://ec.europa.eu/eurostat/data/database (31.01.2020). 
What seems interesting from the point of view of income distribution is not only a comparison of the Gini coefficient value, which in fact is not particularly indicative of the structure of inequality within the distribution, but also of other measures, such as quintile share ratios - S80/S20, S80/S50, S50/S20 - which represent the ratio of total income received by the $20 \%$ of the population with the highest income to that received by the $20 \%$ of the population with the lowest income, the ratio of total income received by the $20 \%$ of the population with the highest income to that received by the middle $20 \%$ in the income distribution, the ratio of total income received by the middle $20 \%$ in the income distribution to that received by the $20 \%$ of the population with the lowest income, respectively. On their basis, more can be said about the concentration of inequality within the income distribution. And so, for example, Poland and Denmark show the same degree of income inequality when measured by the Gini coefficient (27.8\%). However, if we look at the quintile share ratios, we can see that inequality existing in Poland is slightly greater at the bottom of the distribution, and for Denmark - in the upper part of the income distribution.

Table 5.6 shows the values of the Gini coefficient concerning not only disposable household income in individual EU member states but also income before social transfers including and excluding pensions.

Table 5.7. Poverty risk* in Poland compared with other EU countries in $\mathbf{2 0 1 0 - 2 0 1 8 * *}$

\begin{tabular}{|c|c|c|c|c|c|c|c|c|c|c|}
\hline \multirow[b]{2}{*}{ Country/Region } & 2010 & 2014 & 2017 & 2018 & \multicolumn{6}{|c|}{2018} \\
\hline & \multicolumn{4}{|c|}{$\begin{array}{l}\text { at-risk-of-poverty rate after } \\
\text { social transfers }\end{array}$} & 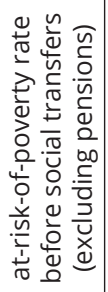 & 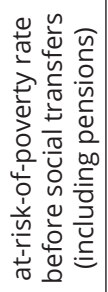 & 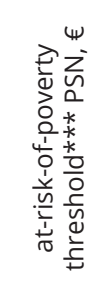 & 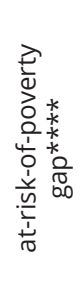 & 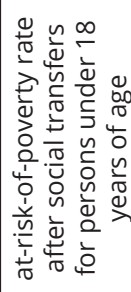 & 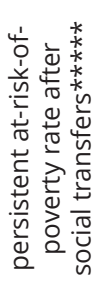 \\
\hline Czech Republic & 9.0 & 9.7 & 9.1 & 9.6 & 15.6 & 34.0 & 16,787 & 15.0 & 11.0 & 6.3 \\
\hline Finland & 13.1 & 12.8 & 11.5 & 12.0 & 25.9 & 43.2 & 25,265 & 14.2 & 11.1 & 5.2 \\
\hline Slovakia & 12.0 & 12.6 & 12.4 & 12.2 & 17.7 & 37.1 & 13,473 & 25.6 & 20.5 & 7.7 \\
\hline Denmark & 13.3 & 12.1 & 12.4 & 12.7 & 24.1 & 39.2 & 27,317 & 19.1 & 11.0 & 4.7 \\
\hline Hungary & 12.3 & 15.0 & 13.4 & 12.8 & 25.0 & 46.1 & 10,844 & 24.1 & 13.8 & 5.7 \\
\hline Netherlands & 10.3 & 11.6 & 13.2 & 13.3 & 21.8 & 37.9 & 26,997 & 18.3 & 13.1 & 8.0 \\
\hline Slovenia & 12.7 & 14.5 & 13.3 & 13.3 & 23.4 & 40.5 & 19,923 & 17.5 & 11.7 & 7.7 \\
\hline France & 13.2 & 13.2 & 13.2 & 13.4 & 24.1 & 45.7 & 25,578 & 16.8 & 19.9 & 7.8 \\
\hline Austria & 14.7 & 14.1 & 14.4 & 14.3 & 25.2 & 43.3 & 29,218 & 21.7 & 19.2 & 10.2 \\
\hline Poland & 17.7 & 16.8 & 15.0 & 14.8 & 24.8 & 44.4 & 14,621 & 23.3 & 13.0 & 10.5 \\
\hline Ireland & 15.2 & 16.4 & 15.6 & 14.9 & 30.9 & 41.0 & 24,676 & 15.3 & 15.8 & 9.3 \\
\hline
\end{tabular}




\begin{tabular}{|c|c|c|c|c|c|c|c|c|c|c|}
\hline \multirow[b]{2}{*}{ Country/Region } & 2010 & 2014 & 2017 & 2018 & \multicolumn{6}{|c|}{2018} \\
\hline & \multicolumn{4}{|c|}{$\begin{array}{l}\text { at-risk-of-poverty rate after } \\
\text { social transfers }\end{array}$} & 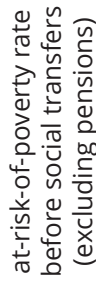 & 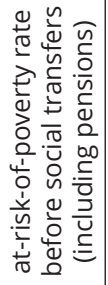 & 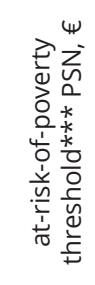 & 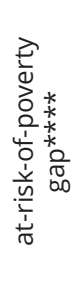 & 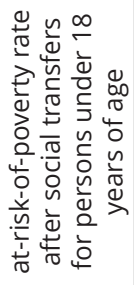 & 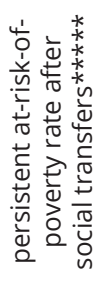 \\
\hline Cyprus & 15.6 & 14.4 & 15.7 & 15.4 & 24.2 & 36.9 & 21,594 & 18.6 & 17.3 & 7.1 \\
\hline Germany & 15.7 & 16.7 & 16.1 & 16.0 & 24.0 & 42.0 & 27,506 & 22.0 & 14.5 & 10.5 \\
\hline Belgium & 14.5 & 15.5 & 15.9 & 16.4 & 25.1 & 42.2 & 27,002 & 19.2 & 20.6 & 10.1 \\
\hline Sweden & 14.8 & 15.6 & 15.8 & 16.4 & 28.9 & 44.3 & 25,643 & 19.9 & 19.3 & 5.7 \\
\hline Malta & 15.5 & 15.9 & 16.7 & 16.8 & 24.2 & 37.0 & 22,801 & 17.0 & 21.4 & 10.9 \\
\hline EU & 16.5 & 17.2 & 16.9 & 17.1 & 25.6 & 43.7 & - & 24.6 & 20.3 & 10.8 \\
\hline Portugal & 17.9 & 19.5 & 18.3 & 17.3 & 22.7 & 43.7 & 13,697 & 24.5 & 19.0 & 14.2 \\
\hline Luxembourg & 14.5 & 16.4 & 18.7 & 18.3 & 27.5 & 46.0 & 40,314 & 24.4 & 22.7 & 9.4 \\
\hline Greece & 20.1 & 22.1 & 20.2 & 18.5 & 23.2 & 50.0 & 11,596 & 29.1 & 22.7 & 12.5 \\
\hline United Kingdom & 17.1 & 16.8 & 17.0 & 18.9 & 29.5 & 43.7 & 22,702 & 24.9 & 24.1 & 7.8 \\
\hline Croatia & 20.6 & 19.4 & 20.0 & 19.3 & 25.7 & 42.9 & 12,445 & 28.9 & 19.7 & 14.8 \\
\hline Italy & 18.7 & 19.4 & 20.3 & 20.3 & 25.9 & 45.8 & 21,036 & 29.5 & 26.2 & 15.3 \\
\hline Spain & 20.7 & 22.2 & 21.6 & 21.5 & 27.9 & 44.6 & 20,150 & 28.5 & 26.8 & 14.0 \\
\hline Estonia & 15.9 & 21.9 & 21.0 & 21.9 & 29.9 & 38.7 & 16,977 & 21.9 & 15.2 & 15.6 \\
\hline Bulgaria & 20.7 & 21.7 & 23.4 & 22.0 & 29.5 & 45.2 & 9,121 & 26.9 & 26.6 & 15.9 \\
\hline Lithuania & 20.5 & 19.2 & 22.9 & 22.9 & 29.7 & 41.8 & 13,461 & 28.2 & 23.9 & 16.1 \\
\hline Latvia & 20.9 & 21.0 & 22.1 & 23.3 & 28.8 & 39.1 & 12,695 & 27.8 & 17.5 & 15.5 \\
\hline Romania & 21.6 & 25.0 & 23.6 & 23.5 & 28.0 & 45.9 & 7,864 & 35.2 & 32.0 & 19.9 \\
\hline
\end{tabular}

* Relative at-risk-of-poverty rates for the poverty line at $60 \%$ of the equivalent median income. ** Countries in the table have been ranked according to the rising at-risk-of-poverty rate after social transfers in 2018 . *** The at-risk-of-poverty threshold has been defined for a household consisting of two adults and two children under 14 years of age. $* * * *$ The at-risk-of-poverty gap is measured here by how much the median income of people considered poor is less than $60 \%$ of the equivalent median income, i.e., the value assumed for the poverty line in the case of at-risk-of-poverty rates analyzed in the table. ${ }^{*} * * *$ The persistent at-risk-of-poverty rate after social transfers refers in the case of Slovakia to 2016, and in the case of Ireland, Portugal, United Kingdom and Lithuania to 2017.

Source: Ibidem.

The measures represent the extent to which the social welfare system and the social security system affects the redistribution of household income. Total social transfers, i.e. including pensions, are defined here as monetary transfers only, comprising, among other components, retirement and disability pensions, family allowances, sickness allowances, disability benefits, as well as benefits related to education, social assistance, or housing allowances. Social transfers - whether before or after pensions - have the strongest impact on the alleviation of income disparities 
in such countries as Sweden, Greece, Portugal, and Germany. The weakest redistribution effect of social transfers is witnessed in the Baltic states - Lithuania, Estonia and Latvia. The only exception among EU member states is Ireland, where the impact of pensions on the alleviation of income inequality is the lowest, and that of total social transfer is moderate. In Poland, the role of social transfers (including and excluding pensions) in reducing income disparities is moderately low, and lower than the EU average, yet the starting level of income inequality (i.e. without social transfers) is also correspondingly lower (compared to the EU average).

In 2018, in the European Union, $17.1 \%$ of people were at risk of poverty, i.e. $17.1 \%$ had a disposable income below $60 \%$ of the median equivalized disposable income ${ }^{4}$. Unlike 2016-2017, this meant an increase in the risk of poverty compared with the previous year by $0.2 \mathrm{pp}$. However, as is the case with income disparities, the percentage of people at risk of poverty decreased from $14.5 \mathrm{pp}$ in 2017 to $13.9 \mathrm{pp}$ in 2018. The lowest risk of poverty in 2018 was reported in the Czech Republic (9.6\%), Finland (12\%) and Slovakia (12.2\%), and the highest in Romania (23.5\%), Latvia (23.3\%) and Lithuania (22.9\%). Compared with 2017, the risk of poverty 2018 decreased the most in Greece (by 1.7 pp), Bulgaria (by 1.4 pp) and Portugal (by 1 pp), and increased the most in the United Kingdom (by 1.9 pp), Latvia (by 1.2 pp) and Estonia (by 0.9 pp). Unlike the poverty and risk-of-poverty measures used and published by GUS, the basic at-risk-of-poverty rate released by Eurostat showed a decline for another year in succession for Poland. The risk of poverty in Poland in 2018 was 2.3 pp lower than the EU average at the time (17.1\%). The correlation coefficient between the at-risk-of-poverty rate and the at-risk-of-poverty threshold (PPP in EUR) in individual EU countries was -0.35 in 2018, which means a weaker negative correlation between those variables compared with $2017(-0.43)$.

Eurostat also reports - as in the case of income inequality - the at-risk-of-poverty rates relating to income excluding social transfers, including and excluding pensions, which makes it possible to assess how these income components account for the reduction of the risk of poverty in individual EU member states. The states in which the role of social transfers excluding pensions was particularly high in this dimension in the EU context were: Greece (at-risk-of-poverty rate reduction by $26.8 \mathrm{pp}$ ), France (by 21.6 pp), Hungary (by 21.1 pp), and Portugal (by 21 pp). The lowest impact of social transfers excluding pensions on reduction of the risk of poverty in 2018 was reported in Estonia (at-risk-of-poverty rate reduction by 8.8 pp), Latvia (by 10.3 pp),

\footnotetext{
4 As is the case with income inequality, the at-risk-of-poverty measure for the whole European Union is the population-weighted average for individual EU countries.
} 
and Lithuania (by $12.1 \mathrm{pp}$ ). In Poland, the role of social transfers (whether excluding or including pensions) was relatively high compared with other EU states.

Other measures provided by Eurostat, such as the at-risk-of-poverty gap, persistent at-risk-of-poverty rate, and at-risk-of-poverty rate for people under 18 years of age, can be used to assess poverty severity or risk of poverty. In 2018, The at-risk-of-poverty gap, which indicates by how much (in \%) the median income of people considered at risk of poverty is lower (the threshold being $60 \%$ of the median equivalized income), was the highest in Romania, Italy, and Greece, and the lowest in Finland, Czech Republic, and Ireland. Poverty depth in Poland is slightly below the EU average; nevertheless, the measure has remained at a similar level since 2009. The persistent at-risk-of-poverty rate, i.e. the percentage of the population with income below the at-risk-of-poverty threshold (60\% of the median equivalized income) for the current year and at least two out of the preceding three years, was the highest in Romania, Lithuania and Bulgaria, and the lowest in Denmark, Finland, Hungary, and Sweden. Poland (with a rate of $10.5 \%$ ) ranked worse in this category compared with its rankings for the measures reviewed previously, and quite close to the EU average (10.8\%). It scored quite well in a ranking of countries with the lowest at-risk-of-poverty rate in the under-18-yearold group, where it took the fifth place among EU member states. The countries with the lowest at-risk-of-poverty rate for people under 18 years of age in 2018 included: Denmark, Czech Republic, Finland and Slovenia, and the countries with the highest value of this measure were Romania, Spain, Bulgaria, and Italy.

\subsection{Conclusions}

Income inequality and poverty or risk of poverty are significant aspects in assessing economic competitiveness. However, it is not until recent years that they started to be noticed in the international literature, i.e. a relatively new argument has emerged that, apart from traditional parameters of competitiveness assessment at country level, such as productivity, innovation performance and technologies, or trade competitiveness, inclusive development is also important. Nevertheless, income inequality, poverty and risk of poverty had already been highlighted in many previous editions of the Report as one of the determinants of the competitiveness of economies.

EU-SILC data shows both a drop in income inequality and decreasing risk of poverty in Poland in 2018 compared with the previous year, whereas in the case of income dispersion and poverty measures calculated on the basis of BBGD data the phenomena are seen to have deepened. EUROSTAT data shows that in 2018 Poland, compared with other EU member states, saw a moderate income inequality at $27.8 \%$, 
slightly lower than the UE average (30.9\%). According to EU-SILC data, Poland showed a decrease in income inequality for another year in succession. The role of social transfers in Poland (including and excluding pensions) in reducing income disparities was moderately low, and lower than the EU average, yet the starting level of income inequality (i.e. without social transfers) was also respectively lower (compared with the EU average). The risk of poverty in Poland in 2018 was 2.3 pp lower than the EU average (17.1\%), whereas the role of social transfers (whether excluding or including pensions) was relatively high compared with other EU states. Poverty depth in Poland, as measured by the relative median at-risk-of-poverty gap, was slightly below the EU average in 2018; however, it should be noted that the measure has remained at a similar level since 2009. Poland performs quite well in a ranking of countries in terms of the lowest at-risk-of-poverty rate in the under-18-year-old group, scoring fifth among EU member states.

\section{Bibliography}

Annoni, P., Dijkstra, L. [2019], The EU regional competitiveness index 2019, European Commission, Luxembourg.

Castellani, D., Koch, A. [2015], Mapping competitiveness with European data, Bruegel Blueprint.

De Fuentes, C. et al. [2015], Determinants of innovation and productivity in the service sector in Mexico, "Emerging Markets Finance and Trade", Vol. 51(3), pp. 578-592.

European Commission [2018], Measuring Competitiveness, background documents for the European Semester, Ref. Ares (2018) 1159686-01/03/2018.

Eurostat EU-SILC, https://ec.europa.eu/eurostat/data/database (31.01.2020).

Graca-Gelert, P. [2019] Income Inequality and Poverty in Poland in 2010-2017 in the Context of the Social Dimension of Industry 4.0., in: A.M. Kowalski, M.A. Weresa (eds.), Poland. Competitiveness Report 2019. International Competitiveness in the Context of Development of Industry 4.0, SGH Publishing House, Warsaw, pp. 83-110.

GUS [2018], Aneks do opracowania sygnalnego „Zasięg ubóstwa ekonomicznego w Polsce w 2017 r.”, GUS, Warsaw.

GUS [2019a], Budżety gospodarstw domowych w 2018 r., GUS, Warsaw.

GUS [2019b], Zasięg ubóstwa ekonomicznego w Polsce w 2018r. (informacje sygnalne), GUS, Warsaw.

Kuznets, S. [1955], Economic Growth and Income Inequality, "The American Economic Review”, Vol. 45 (1), pp. 1-28.

Momaya, K. [1998], Evaluating international competitiveness at the industry level, "Vikalpa", Vol. 23(2), pp. 39-46. 
Neagu, O., Teodoru, M.C. [2018], The economic competitiveness and inclusive development nexus: empirical evidence from 101 economies, "Studia Universitatis «Vasile Goldis» Arad Economics Series", Vol. 28(3), pp. 1-19.

OECD IID, https://stats.oecd.org/Index.aspx?DataSetCode=IDD (31.01.2020).

Ostry, J.D., Berg, A., Tsangarides, C.G. [2014], Redistribution, inequality, and growth, IMF.

Schwab, K. (ed.) [2019], The global competitiveness report 2019, World Economic Forum.

Weresa, M.A. (ed.) [2015], Poland. Competitiveness Report 2015. Innovation and Poland's Performance in 2007-2014, SGH Publishing House, Warsaw.

Weresa, M.A., Kowalski, A.M. (eds.) [2018], Poland. Competitiveness Report 2018. The Role of Cities in Creating Competitive Advantages, SGH Publishing House, Warsaw.

Wölfl, A. [2003], Productivity growth in service industries, OECD Science, Technology and Industry Working Papers, No. 2003/07. 

Chapter 6

\section{Competitiveness of the Polish Service Sector in Foreign Trade}

Mariusz Jan Radło

\subsection{Introductory Notes}

The purpose of this chapter is to present the results of the analysis of Poland's competitiveness in trade in services - taking into account the directions of trade, its trade balance, its structure and the revealed comparative advantages. This chapter consists of several parts. The introduction is followed by an overview of the main trends in Polish trade in services in 2010-2018/2019 and the results of a geographical analysis of the directions of trade in services. Presented next is an analysis of the structure of trade in services, including the structure of exports, imports, and the balance of trade in services. The results of the analysis of the revealed comparative advantages in the Polish trade in services are then described. In the last part of the study, an attempt is made to describe the potential impact of the COVID-19 pandemic on Polish trade in services. The chapter concludes with a summary of the results of the studies. The study used data from the National Bank of Poland on trade in services and balance of payments.

\subsection{Long-term Trends in Polish Trade in Services and Its Directions}

An analysis of the data presented in Figure 6.1 shows that between 2004 and 2019 Poland recorded a steady increase in trade in services, characterized by a faster growth of exports than imports of services, which resulted in annual increases in the positive balance in trade in services. During the period under consideration, the value of service exports increased from PLN 106.9 bn in 2010 to PLN 276.3 bn in 2019. At the same time, the value of service imports increased from PLN 93.7 bn to PLN 169.31 bn. 
Consequently, during the period analyzed, an increase of the positive balance of trade in services was recorded, from PLN 13.2 bn in 2010 to PLN 108.2 bn in 2019.

Figure 6.1. Polish trade in services in 2010-2019 (annual data in PLN bn)

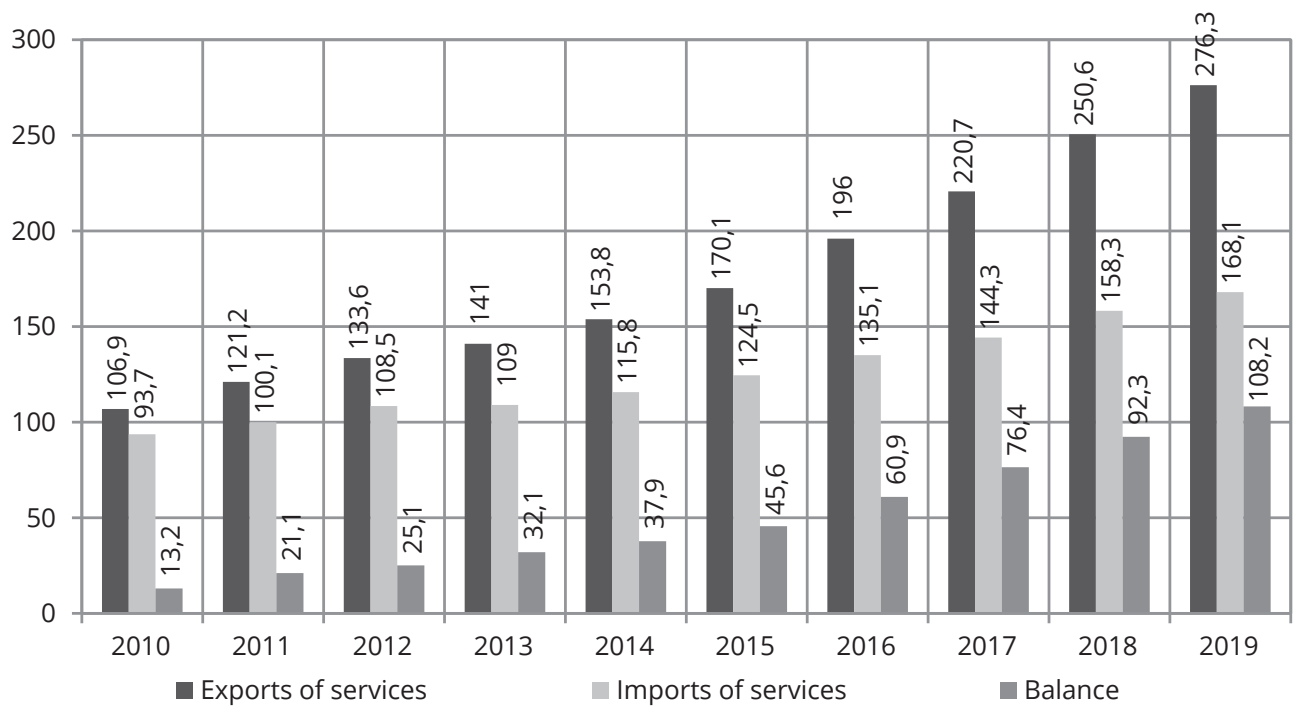

Source: Own study based on NBP data (Balance of payment statistics. Balance of payments - annual data).

Figure 6.2. Polish trade in services in $2010-2020$ (annual data in PLN bn)

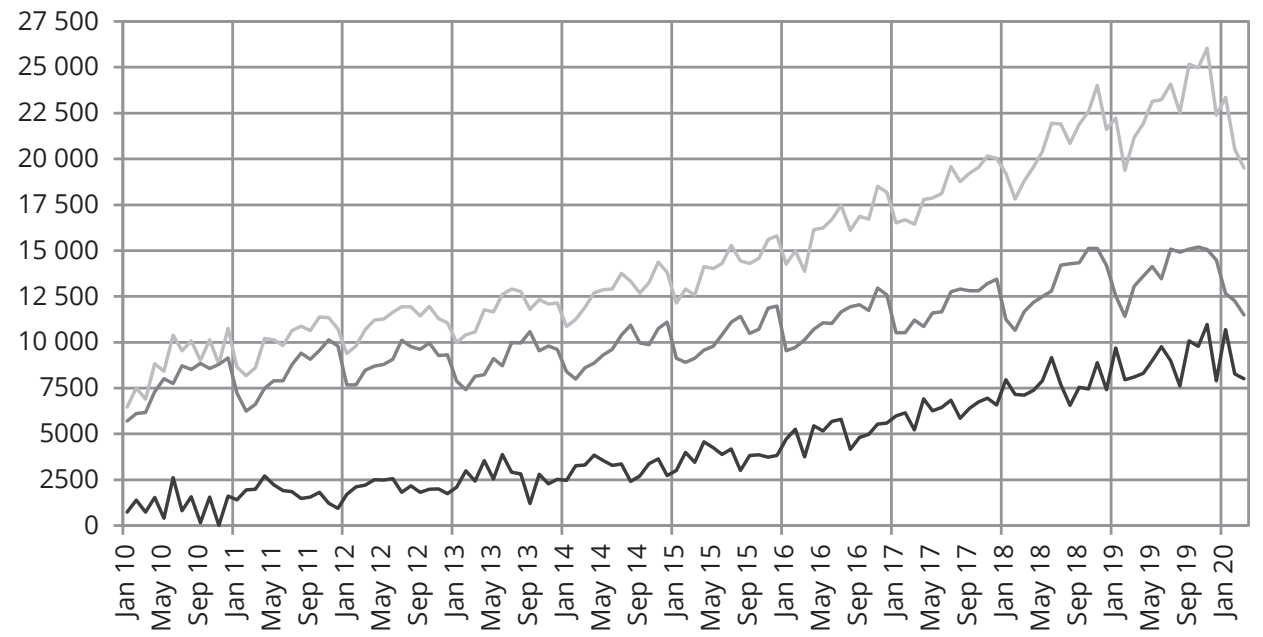

—Balance on services — _ Services: debit _ _ Services: credit

Note: Monthly data for the period January 2004 - October 2019.

Source: Own study based on NBP data (Balance of payment statistics. Balance of payments - monthly data). 
In addition, according to monthly data on trade in services, as presented in Figure 6.2, the trends described above continued also in 2019. In contrast, the first quarter of 2020 saw a cyclical decline in exports and imports of services, with a continued surplus in trade in services. Compared with data for previous years, no marked impact of the crisis in trade in certain services has yet been reported this year in connection with the COVID-19 spread. Nevertheless, changes in this respect can be expected in the second quarter. Unfortunately, at the time of preparing this study, statistical data for the period concerned was not yet available.

\subsection{Geographical Structure of Polish Trade in Services}

Table 6.1 shows data on the geographical structure of Polish trade in services. Their analysis shows that in 2010-2018 the EU markets were the main direction of export of services from Poland, although there share in total exports of services dropped from $71 \%$ in 2010 to $69.5 \%$ in 2018. Among the EU member states, those with the highest share in Polish exports of services in 2018 were Germany (22.7\%), the United Kingdom (7.5\%), the Netherlands (6.8\%), France (4.0\%), and Sweden (3.4\%). Also countries outside the EU, such as Switzerland (7.7\%), the United States (6.4\%), or Ukraine (5.5\%) had a large share in Polish exports of services.

Table 6.1. Geographical structure of Polish export of services - revenue in 2010-2018 (in \%)

\begin{tabular}{|l|c|c|c|c|c|c|c|c|c|}
\hline \multicolumn{1}{|c|}{ Country name } & 2010 & 2011 & 2012 & 2013 & 2014 & 2015 & 2016 & 2017 & 2018 \\
\hline World total & 100 & 100 & 100 & 100 & 100 & 100 & 100 & 100 & 100 \\
\hline \hline Africa & 0.4 & 0.3 & 0.4 & 0.5 & 0.6 & 0.4 & 0.4 & 0.3 & 0.2 \\
\hline South America & 0.1 & 0.1 & 0.1 & 0.1 & 0.1 & 0.1 & 0.2 & 0.1 & 0.2 \\
\hline North America & 4.9 & 5.1 & 5.3 & 5.5 & 5.8 & 6.4 & 6.7 & 7.0 & 7.3 \\
\hline Australia and Oceania & 0.2 & 0.2 & 0.3 & 0.2 & 0.2 & 0.3 & 0.3 & 0.2 & 0.2 \\
\hline Austria & 2.5 & 2.8 & 2.3 & 2.2 & 2.1 & 2.1 & 2.0 & 1.9 & 1.9 \\
\hline Belgium & 2.9 & 3 & 2.8 & 2.6 & 2.6 & 2.6 & 2.8 & 2.6 & 2.4 \\
\hline Bulgaria & 0.3 & 0.3 & 0.3 & 0.3 & 0.3 & 0.3 & 0.3 & 0.3 & 0.2 \\
\hline China & 0.3 & 0.3 & 0.4 & 0.3 & 0.4 & 0.5 & 0.5 & 0.6 & 0.7 \\
\hline Cyprus & 0.6 & 0.5 & 0.6 & 0.6 & 0.6 & 0.4 & 0.4 & 0.4 & 0.4 \\
\hline Denmark & 1.8 & 1.9 & 2.0 & 2.1 & 2.3 & 2.4 & 2.4 & 2.4 & 2.4 \\
\hline Finland & 1.0 & 1.2 & 1.2 & 1.2 & 1.3 & 1.5 & 1.4 & 1.4 & 1.5 \\
\hline France & 4.6 & 4.8 & 4.4 & 4.7 & 4.5 & 4.3 & 4.3 & 4.0 & 4 \\
\hline Greece & 0.2 & 0.2 & 0.2 & 0.2 & 0.2 & 0.1 & 0.2 & 0.2 & 0.2 \\
\hline
\end{tabular}


cont. tab. 6.1

\begin{tabular}{|l|c|c|c|c|c|c|c|c|c|}
\hline \multicolumn{1}{|c|}{ Country name } & 2010 & 2011 & 2012 & 2013 & 2014 & 2015 & 2016 & 2017 & 2018 \\
\hline Spain & 1.2 & 1.3 & 1.1 & 1.1 & 1.1 & 1.2 & 1.2 & 1.3 & 1.2 \\
\hline Ireland & 1.9 & 2.0 & 1.9 & 2.2 & 2.2 & 2.4 & 2.5 & 2.4 & 2.4 \\
\hline Lithuania & 1.3 & 1.2 & 1.3 & 1.4 & 1.2 & 1.1 & 1.0 & 1.0 & 1.1 \\
\hline Luxembourg & 0.7 & 0.9 & 0.9 & 0.9 & 1.2 & 1.7 & 1.6 & 1.8 & 1.9 \\
\hline Latvia & 0.3 & 0.3 & 0.3 & 0.4 & 0.5 & 0.4 & 0.4 & 0.4 & 0.4 \\
\hline Malta & 0.2 & 0.1 & 0.1 & 0.1 & 0.2 & 0.2 & 0.2 & 0.2 & 0.2 \\
\hline Netherlands & 5.5 & 6.2 & 5.8 & 6.1 & 5.8 & 5.7 & 5.8 & 6.2 & 6.8 \\
\hline Germany & 25.9 & 24.9 & 25.2 & 24.4 & 24.2 & 23.5 & 23.3 & 23.1 & 22.7 \\
\hline Portugal & 0.2 & 0.2 & 0.2 & 0.2 & 0.2 & 0.2 & 0.2 & 0.3 & 0.3 \\
\hline Outside the European Union (28) & 29 & 29 & 30 & 30.5 & 30.7 & 30.4 & 30.4 & 31 & 30.5 \\
\hline Czech Republic & 4.3 & 4.4 & 4.5 & 3.9 & 3.6 & 3.4 & 3.3 & 3.1 & 3.0 \\
\hline Russia & 3.2 & 3.3 & 3.6 & 3.7 & 3.2 & 2.3 & 2.0 & 1.7 & 1.8 \\
\hline Romania & 0.5 & 0.4 & 0.4 & 0.5 & 0.5 & 0.5 & 0.5 & 0.5 & 0.6 \\
\hline Slovakia & 2.5 & 2.3 & 2.5 & 2.2 & 1.8 & 1.8 & 1.7 & 1.6 & 1.5 \\
\hline Slovenia & 0.2 & 0.2 & 0.2 & 0.2 & 0.2 & 0.2 & 0.2 & 0.2 & 0.2 \\
\hline United States of America & 4.3 & 4.6 & 4.8 & 5.0 & 5.2 & 5.8 & 5.7 & 6.1 & 6.4 \\
\hline Switzerland & 8.2 & 7.8 & 7.9 & 7.6 & 8.3 & 8.7 & 8.6 & 8.1 & 7.7 \\
\hline Sweden & 2.5 & 2.5 & 2.6 & 2.5 & 2.9 & 3.0 & 3.2 & 3.2 & 3.4 \\
\hline Ukraine & 4.4 & 4.1 & 4.2 & 4.5 & 4.2 & 4.6 & 5.1 & 5.8 & 5.5 \\
\hline European Union (28) & $\mathbf{7 1}$ & $\mathbf{7 1}$ & $\mathbf{7 0}$ & $\mathbf{6 9 . 5}$ & $\mathbf{6 9 . 3}$ & $\mathbf{6 9 . 6}$ & $\mathbf{6 9 . 6}$ & $\mathbf{6 9}$ & $\mathbf{6 9 . 5}$ \\
\hline Hungary & 1.1 & 0.9 & 0.9 & 1.0 & 1.0 & 1.0 & 1.0 & 1.0 & 1.0 \\
\hline United Kingdom & 6.5 & 6.3 & 5.9 & 6.1 & 6.4 & 7.0 & 7.1 & 7.3 & 7.5 \\
\hline Italy & 2.2 & 2.0 & 2.0 & 2.1 & 2.2 & 2.0 & 2.1 & 2.1 & 2.0 \\
\hline Asia & $\mathbf{2 . 7}$ & $\mathbf{2 . 6}$ & $\mathbf{2 . 4}$ & $\mathbf{2 . 4}$ & $\mathbf{2 . 9}$ & $\mathbf{3}$ & $\mathbf{3 . 2}$ & $\mathbf{3 . 5}$ & $\mathbf{4 . 1}$ \\
\hline
\end{tabular}

Source: Own study based on NBP data (Balance of payment statistics. International trade in services).

Table 6.2. Geographical structure of Polish export of services - revenue in 2010-2018 (in \%)

\begin{tabular}{|l|r|r|r|r|r|r|r|r|r|}
\hline \multicolumn{1}{|c|}{ Country name } & 2010 & 2011 & 2012 & 2013 & 2014 & 2015 & 2016 & 2017 & 2018 \\
\hline World total & 100.0 & 100.0 & 100.0 & 100.0 & 100.0 & 100.0 & 100.0 & 100.0 & 100.0 \\
\hline \hline Africa & 2.7 & 2.2 & 1.8 & 1.5 & 1.1 & 0.9 & 0.6 & 0.7 & 0.7 \\
\hline South America & 0.1 & 0.1 & 0.1 & 0.1 & 0.2 & 0.2 & 0.2 & 0.1 & 0.2 \\
\hline North America & 5.7 & 5.8 & 5.9 & 5.6 & 5.7 & 5.5 & 5.7 & 5.5 & 5.6 \\
\hline Australia and Oceania & 0.2 & 0.2 & 0.1 & 0.3 & 0.2 & 0.2 & 0.3 & 0.3 & 0.3 \\
\hline Austria & 2.9 & 3.3 & 3.3 & 3.3 & 3.1 & 2.9 & 2.9 & 3.0 & 3.0 \\
\hline Belgium & 2.8 & 2.7 & 3.1 & 2.8 & 2.5 & 2.4 & 2.5 & 2.5 & 2.4 \\
\hline Bulgaria & 0.6 & 0.5 & 0.5 & 0.7 & 0.6 & 0.5 & 0.7 & 0.6 & 0.7 \\
\hline
\end{tabular}




\begin{tabular}{|c|c|c|c|c|c|c|c|c|c|}
\hline Country name & 2010 & 2011 & 2012 & 2013 & 2014 & 2015 & 2016 & 2017 & 2018 \\
\hline China & 0.7 & 0.8 & 0.7 & 0.7 & 0.8 & 0.9 & 1.0 & 1.2 & 1.4 \\
\hline Croatia & 0.6 & 0.8 & 0.6 & 0.7 & 1.1 & 1.1 & 1.0 & 1.1 & 1.1 \\
\hline Cyprus & 1.1 & 1.2 & 1.1 & 1.4 & 1.3 & 1.2 & 1.1 & 1.2 & 1.1 \\
\hline Denmark & 2.1 & 2.3 & 2.1 & 2.0 & 2.1 & 2.3 & 2.1 & 2.1 & 2.0 \\
\hline Estonia & 0.1 & 0.2 & 0.2 & 0.2 & 0.2 & 0.2 & 0.2 & 0.4 & 0.4 \\
\hline Finland & 0.9 & 0.8 & 0.8 & 0.8 & 0.8 & 0.8 & 0.7 & 0.7 & 0.7 \\
\hline France & 5.8 & 5.4 & 5.7 & 6.5 & 5.8 & 5.9 & 5.7 & 5.6 & 5.5 \\
\hline Greece & 1.0 & 0.9 & 0.5 & 0.6 & 1.1 & 1.1 & 1.1 & 1.1 & 1.1 \\
\hline Spain & 2.3 & 2.3 & 1.8 & 1.9 & 2.0 & 2.2 & 2.2 & 2.4 & 2.4 \\
\hline Ireland & 1.9 & 2.2 & 2.4 & 2.4 & 2.8 & 2.9 & 3.3 & 4.1 & 4.5 \\
\hline Lithuania & 1.0 & 1.1 & 1.0 & 1.3 & 1.1 & 1.0 & 1.0 & 1.0 & 1.1 \\
\hline Luxembourg & 0.9 & 1.0 & 1.2 & 1.3 & 1.3 & 1.2 & 1.4 & 1.2 & 1.2 \\
\hline Latvia & 0.3 & 0.3 & 0.4 & 0.3 & 0.3 & 0.3 & 0.3 & 0.3 & 0.3 \\
\hline Malta & 0.2 & 0.3 & 0.2 & 0.2 & 0.2 & 0.3 & 0.3 & 0.3 & 0.3 \\
\hline Netherlands & 5.2 & 5.3 & 5.8 & 5.6 & 5.3 & 5.1 & 5.2 & 5.3 & 5.5 \\
\hline Germany & 22.5 & 22.8 & 23.2 & 21.8 & 21.9 & 21.5 & 21.9 & 21.8 & 21.5 \\
\hline Portugal & 0.3 & 0.3 & 0.2 & 0.3 & 0.4 & 0.4 & 0.4 & 0.5 & 0.5 \\
\hline Outside the European Union (28) & 22.9 & 22.0 & 21.2 & 22.1 & 22.0 & 21.4 & 20.9 & 20.9 & 20.7 \\
\hline Czech Republic & 5.3 & 5.3 & 5.1 & 5.0 & 5.5 & 5.3 & 5.1 & 4.8 & 4.8 \\
\hline Russia & 1.8 & 1.7 & 2.0 & 2.0 & 1.9 & 1.4 & 1.1 & 1.2 & 1.2 \\
\hline Romania & 0.4 & 0.5 & 0.4 & 0.5 & 0.5 & 0.5 & 0.6 & 0.6 & 0.8 \\
\hline Slovakia & 2.8 & 3.2 & 3.1 & 2.7 & 2.3 & 2.4 & 2.3 & 2.2 & 2.1 \\
\hline United States of America & 5.3 & 5.4 & 5.5 & 5.3 & 5.4 & 5.2 & 5.3 & 5.1 & 5.2 \\
\hline Switzerland & 3.5 & 3.6 & 3.7 & 4.5 & 5.0 & 5.0 & 5.2 & 4.4 & 4.0 \\
\hline Sweden & 2.0 & 2.2 & 2.5 & 2.0 & 2.3 & 2.4 & 2.4 & 2.4 & 2.6 \\
\hline Ukraine & 1.3 & 1.3 & 1.0 & 1.2 & 0.9 & 0.9 & 1.0 & 1.0 & 1.1 \\
\hline European Union (28) & 77.1 & 78.0 & 78.8 & 77.9 & 78.0 & 78.6 & 79.1 & 79.1 & 79.3 \\
\hline Hungary & 0.8 & 0.9 & 1.2 & 1.2 & 1.0 & 1.0 & 1.0 & 1.1 & 1.1 \\
\hline United Kingdom & 7.5 & 7.3 & 7.7 & 7.7 & 7.8 & 8.7 & 8.7 & 8.4 & 8.2 \\
\hline Italy & 5.1 & 3.8 & 3.9 & 4.2 & 4.1 & 4.5 & 4.2 & 3.9 & 4.0 \\
\hline Asia & 3.3 & 3.1 & 3.0 & 3.1 & 3.5 & 3.6 & 3.8 & 4.4 & 4.5 \\
\hline Euro area (19) & 57.1 & 57.2 & 57.9 & 57.8 & 56.8 & 56.3 & 57.0 & 57.6 & 57.8 \\
\hline Outside euro area (19) & 42.9 & 42.8 & 42.1 & 42.2 & 43.2 & 43.7 & 43.0 & 42.4 & 42.2 \\
\hline
\end{tabular}

Source: Ibidem.

Table 6.2 shows data on the geographical structure of Polish imports. They indicate that during the whole analyzed period Poland imported services mainly from the European Union and the position of this direction of import strengthened. While 
in 2010 imports from the EU represented 77.1\% of total imports of services, in 2018 the figure rose to $79.3 \%$. Among the EU member states, those with the highest share in Polish imports of services in 2018 were Germany (21.5\%), the United Kingdom (8.2\%), France (5.5\%), the Netherlands (5.5\%), the Czech Republic (4.8\%), and Ireland (4.5\%). In imports from non-EU countries, the highest share was reported for the United (5.2\%) and (4.0\%). China ranked next, albeit with a small share of 1.4\%.

\subsection{Sectoral Structure of Polish Trade in Services}

Table 6.3 shows data on the sectoral structure of Polish trade in services. The analysis of the data shows that the services with the highest share in exports in 2018 were transport services (27.8\%) - mainly other business services (23.0\%), as well as foreign travel (20.3\%), telecommunication, IT and information services (11.5\%) - especially IT services (9.7\%), and processing (6.9\%). It should also be noted that in 2010-2018 the greatest increase in the share of exports of services was recorded for telecommunication services ( $5.9 \mathrm{pp}$ ) and transport services (2.8 pp). In contrast, a decrease in the share of exports of services was recorded for foreign travel (-6.9 pp), other business services $(-4.2 \mathrm{pp})$, and financial services $(-0.5 \mathrm{pp})$, or construction services $(-0.5 \mathrm{pp})$.

Table 6.3. Export of services from Poland in 2010-2018 (in \% of total export of services)

\begin{tabular}{|c|c|c|c|c|c|c|c|c|c|c|c|}
\hline \multirow{2}{*}{ Code } & \multirow{2}{*}{ Service name } & \multicolumn{9}{|c|}{ Year } & \multirow{2}{*}{$\begin{array}{c}\text { Change } \\
\text { (pp) }\end{array}$} \\
\hline & & 2010 & 2011 & 2012 & 2013 & 2014 & 2015 & 2016 & 2017 & 2018 & \\
\hline SA & processing & 5.0 & 5.4 & 5.8 & 7.5 & 8.0 & 7.7 & 7.5 & 7.2 & 6.9 & 1.9 \\
\hline SB & repairs & 2.0 & 2.2 & 1.4 & 2.3 & 2.4 & 2.6 & 2.7 & 3.0 & 2.8 & 0.8 \\
\hline SC & transport services & 25.1 & 27.1 & 27.2 & 27.3 & 27.3 & 27.0 & 27.2 & 27.0 & 27.8 & 2.8 \\
\hline SC1 & sea transport & 1.0 & 1.1 & 1.1 & 1.1 & 1.1 & 1.0 & 0.9 & 0.9 & 0.8 & -0.2 \\
\hline $\mathrm{SC} 2$ & air transport & 2.6 & 3.2 & 3.2 & 3.3 & 3.0 & 2.8 & 3.2 & 3.3 & 3.5 & 0.9 \\
\hline SC3 & $\begin{array}{l}\text { other transport services } \\
\text { (except sea and air } \\
\text { transport) }\end{array}$ & 21.2 & 22.6 & 22.7 & 22.7 & 22.9 & 22.9 & 22.8 & 22.5 & 23.1 & 1.9 \\
\hline $\mathrm{SC} 3 \mathrm{C}$ & $\begin{array}{l}\text { other transport services } \\
\text { (except sea and air } \\
\text { transport), including road } \\
\text { transport }\end{array}$ & 15.0 & 16.5 & 16.1 & 16.8 & 16.9 & 16.7 & 16.4 & 15.9 & 16.1 & 1.1 \\
\hline SC4 & postal and courier services & 0.2 & 0.2 & 0.2 & 0.2 & 0.2 & 0.3 & 0.3 & 0.3 & 0.4 & 0.2 \\
\hline SD & foreign travel & 27.1 & 26.1 & 26.8 & 25.5 & 24.3 & 23.2 & 22.0 & 21.7 & 20.3 & -6.9 \\
\hline SE & construction services & 3.7 & 4.0 & 3.9 & 3.8 & 3.6 & 3.4 & 3.5 & 3.4 & 3.3 & -0.5 \\
\hline SF & insurance services & 0.6 & 1.0 & 0.7 & 0.7 & 0.5 & 0.9 & 0.9 & 0.8 & 0.6 & 0.0 \\
\hline SG & financial services & 1.9 & 1.7 & 1.7 & 1.6 & 1.6 & 1.5 & 1.4 & 1.6 & 1.4 & -0.5 \\
\hline
\end{tabular}




\begin{tabular}{|c|c|c|c|c|c|c|c|c|c|c|c|}
\hline \multirow{2}{*}{ Code } & \multirow{2}{*}{ Service name } & \multicolumn{9}{|c|}{ Year } & \multirow{2}{*}{$\begin{array}{l}\text { Change } \\
\text { (pp) }\end{array}$} \\
\hline & & 2010 & 2011 & 2012 & 2013 & 2014 & 2015 & 2016 & 2017 & 2018 & \\
\hline $\mathrm{SH}$ & $\begin{array}{l}\text { charges for the use of } \\
\text { intellectual property }\end{array}$ & 0.7 & 0.7 & 0.6 & 0.7 & 0.7 & 0.9 & 0.9 & 1.0 & 0.9 & 0.2 \\
\hline SH1 & $\begin{array}{l}\text { charges for the use of } \\
\text { intellectual property, } \\
\text { including franchise and } \\
\text { trademark fee }\end{array}$ & 0.3 & 0.3 & 0.2 & 0.2 & 0.3 & 0.2 & 0.1 & 0.2 & 0.1 & -0.2 \\
\hline SI & $\begin{array}{l}\text { telecommunication, IT and } \\
\text { information services }\end{array}$ & 5.7 & 6.3 & 7.0 & 7.7 & 8.7 & 9.7 & 10.7 & 10.9 & 11.5 & 5.9 \\
\hline SI1 & $\begin{array}{l}\text { telecommunication } \\
\text { services }\end{array}$ & 1.3 & 1.2 & 1.1 & 1.0 & 0.9 & 0.7 & 1.0 & 0.9 & 1.2 & -0.1 \\
\hline $\mathrm{SI} 2$ & IT services & 3.9 & 4.7 & 5.4 & 6.1 & 7.2 & 8.3 & 8.9 & 9.2 & 9.7 & 5.8 \\
\hline $\mathrm{SI3}$ & information services & 0.4 & 0.5 & 0.4 & 0.5 & 0.6 & 0.7 & 0.8 & 0.8 & 0.6 & 0.2 \\
\hline SJ & other business services & 27.2 & 24.2 & 23.9 & 22.0 & 22.1 & 22.0 & 21.8 & 22.2 & 23.0 & -4.2 \\
\hline SJ1 & $\begin{array}{l}\text { research and development } \\
\text { services }\end{array}$ & 1.6 & 1.8 & 1.7 & 1.8 & 2.2 & 2.3 & 2.1 & 2.3 & 2.4 & 0.9 \\
\hline SJ2 & $\begin{array}{l}\text { services provided by } \\
\text { professionals }\end{array}$ & 9.7 & 10.0 & 10.3 & 11.3 & 11.4 & 11.4 & 11.8 & 11.8 & 12.4 & 2.7 \\
\hline SJ21 & $\begin{array}{l}\text { legal, accounting, } \\
\text { management and public } \\
\text { relations services }\end{array}$ & 4.8 & 5.3 & 5.8 & 6.8 & 7.1 & 7.1 & 7.7 & 7.9 & 8.4 & 3.6 \\
\hline SJ211 & legal services & 0.7 & 0.7 & 0.6 & 0.6 & 0.5 & 0.5 & 0.5 & 0.5 & 0.5 & -0.2 \\
\hline SJ212 & $\begin{array}{l}\text { accounting, auditing and } \\
\text { tax consultancy services }\end{array}$ & 1.8 & 1.7 & 2.0 & 2.3 & 2.5 & 2.8 & 3.1 & 3.3 & 3.6 & 1.8 \\
\hline SJ213 & $\begin{array}{l}\text { business consultancy and } \\
\text { public relations services }\end{array}$ & 2.3 & 2.9 & 3.2 & 3.9 & 4.1 & 3.9 & 4.2 & 4.2 & 4.4 & 2.1 \\
\hline SJ22 & $\begin{array}{l}\text { marketing, market } \\
\text { research and public } \\
\text { opinion polling services }\end{array}$ & 4.9 & 4.6 & 4.5 & 4.5 & 4.3 & 4.2 & 4.1 & 3.8 & 4.0 & -0.9 \\
\hline SJ3 & $\begin{array}{l}\text { technical, trade-related, } \\
\text { and other business } \\
\text { services }\end{array}$ & 15.9 & 12.5 & 11.8 & 8.8 & 8.4 & 8.3 & 7.9 & 8.1 & 8.2 & -7.8 \\
\hline SK & $\begin{array}{l}\text { cultural and recreational } \\
\text { services }\end{array}$ & 0.9 & 1.3 & 0.9 & 0.9 & 0.9 & 1.0 & 1.4 & 1.3 & 1.3 & 0.4 \\
\hline
\end{tabular}

Source: Ibidem.

Data on the structure of imports of services to Poland are presented in Table 6.4. Based on their analysis, it can be concluded that the services with the highest share in imports to Poland in 2018 were business services (25.6\%), transport services (23.3\%), foreign travel (22.2\%), telecommunication, IT and information services (10.0\%), and charges for the use of intellectual property (8.3\%). At the same time, during the analyzed period, the highest increase in imports of services was recorded for transport services (3.1 pp), telecommunication, IT and information services (2.9 pp), repairs (1.9 pp), and other business services (1.8 pp). The highest decrease in the share of total 
imports of services was found in foreign travel ( $-5.5 \mathrm{pp})$, financial services $(-2.9 \mathrm{pp})$, cultural and recreational services $(-1.6 \mathrm{pp})$, and construction services $(-1.1 \mathrm{pp})$.

Table 6.4. Import of services to Poland in 2010-2018 (in PLN bn)

\begin{tabular}{|c|c|c|c|c|c|c|c|c|c|c|c|}
\hline \multirow{2}{*}{ Code } & \multirow{2}{*}{ Service name } & \multicolumn{9}{|c|}{ Year } & \multirow{2}{*}{$\begin{array}{l}\text { Change } \\
\text { (pp) }\end{array}$} \\
\hline & & 2010 & 2011 & 2012 & 2013 & 2014 & 2015 & 2016 & 2017 & 2018 & \\
\hline SA & processing & 0.4 & 0.6 & 0.4 & 0.7 & 0.9 & 1.2 & 1.0 & 1.0 & 1.0 & 0.6 \\
\hline SB & repairs & 0.7 & 0.7 & 0.7 & 2.3 & 2.9 & 2.4 & 2.4 & 2.5 & 2.6 & 1.9 \\
\hline SC & transport services & 20.2 & 20.7 & 21.5 & 20.7 & 21.5 & 21.4 & 22.0 & 22.9 & 23.3 & 3.1 \\
\hline SC1 & sea transport & 3.5 & 3.3 & 3.5 & 3.5 & 3.6 & 3.6 & 3.5 & 3.7 & 3.6 & 0.1 \\
\hline SC2 & air transport & 2.9 & 3.0 & 2.9 & 2.8 & 3.6 & 3.6 & 4.3 & 4.2 & 4.4 & 1.5 \\
\hline SC3 & $\begin{array}{l}\text { other transport services } \\
\text { (except sea and air } \\
\text { transport) }\end{array}$ & 13.4 & 14.0 & 14.7 & 14.0 & 13.9 & 13.7 & 13.8 & 14.4 & 14.6 & 1.3 \\
\hline $\mathrm{SC} 3 \mathrm{C}$ & $\begin{array}{l}\text { other transport services } \\
\text { (except sea and air } \\
\text { transport), including road } \\
\text { transport }\end{array}$ & 9.3 & 10.1 & 10.1 & 10.3 & 10.1 & 10.0 & 10.2 & 10.6 & 10.8 & 1.4 \\
\hline SC4 & postal and courier services & 0.4 & 0.4 & 0.3 & 0.4 & 0.3 & 0.5 & 0.5 & 0.6 & 0.7 & 0.3 \\
\hline SD & foreign travel & 27.8 & 24.9 & 26.4 & 25.7 & 24.1 & 24.0 & 23.3 & 23.0 & 22.2 & -5.5 \\
\hline SE & construction services & 2.3 & 2.1 & 2.4 & 2.4 & 2.2 & 3.2 & 1.5 & 1.2 & 1.2 & -1.1 \\
\hline SF & insurance services & 1.8 & 2.1 & 2.2 & 2.1 & 2.3 & 2.2 & 2.4 & 1.8 & 1.7 & -0.1 \\
\hline SG & financial services & 5.3 & 5.2 & 4.7 & 3.4 & 3.2 & 3.0 & 2.9 & 2.5 & 2.4 & -2.9 \\
\hline $\mathrm{SH}$ & $\begin{array}{l}\text { charges for the use of } \\
\text { intellectual property }\end{array}$ & 7.2 & 7.1 & 7.0 & 7.8 & 8.1 & 7.4 & 7.9 & 8.2 & 8.3 & 1.1 \\
\hline $\mathrm{SH} 1$ & $\begin{array}{l}\text { charges for the use of } \\
\text { intellectual property, } \\
\text { including franchise and } \\
\text { trademark fee }\end{array}$ & 1.4 & 1.9 & 2.9 & 3.9 & 3.7 & 3.3 & 3.9 & 3.8 & 3.6 & 2.2 \\
\hline SI & $\begin{array}{l}\text { telecommunication, IT and } \\
\text { information services }\end{array}$ & 7.1 & 7.1 & 7.5 & 8.2 & 8.2 & 8.4 & 9.2 & 9.5 & 10.0 & 2.9 \\
\hline SI1 & $\begin{array}{l}\text { telecommunication } \\
\text { services }\end{array}$ & 1.7 & 1.4 & 1.6 & 1.6 & 1.4 & 1.5 & 1.4 & 1.9 & 1.7 & 0.0 \\
\hline $\mathrm{SI} 2$ & IT services & 4.7 & 5.3 & 5.4 & 6.1 & 6.3 & 6.4 & 7.0 & 6.9 & 7.5 & 2.8 \\
\hline $\mathrm{SI3}$ & information services & 0.6 & 0.4 & 0.5 & 0.6 & 0.5 & 0.5 & 0.7 & 0.8 & 0.7 & 0.1 \\
\hline SJ & other business services & 23.8 & 24.3 & 23.5 & 24.0 & 24.1 & 24.3 & 24.9 & 24.9 & 25.6 & 1.8 \\
\hline SJ1 & $\begin{array}{l}\text { research and development } \\
\text { services }\end{array}$ & 0.5 & 0.6 & 0.6 & 0.8 & 0.9 & 0.8 & 0.9 & 0.7 & 0.7 & 0.2 \\
\hline SJ2 & $\begin{array}{l}\text { services provided by } \\
\text { professionals }\end{array}$ & 7.8 & 9.5 & 9.8 & 13.4 & 13.8 & 13.9 & 14.4 & 14.1 & 14.5 & 6.7 \\
\hline SJ21 & $\begin{array}{l}\text { legal, accounting, } \\
\text { management and public } \\
\text { relations services }\end{array}$ & 6.2 & 7.5 & 7.8 & 11.0 & 11.2 & 11.1 & 11.2 & 10.7 & 10.7 & 4.5 \\
\hline SJ211 & legal services & 0.5 & 0.5 & 0.4 & 0.4 & 0.4 & 0.4 & 0.4 & 0.3 & 0.3 & -0.2 \\
\hline
\end{tabular}




\begin{tabular}{|c|c|c|c|c|c|c|c|c|c|c|c|}
\hline \multirow{2}{*}{ Code } & \multirow{2}{*}{ Service name } & \multicolumn{9}{|c|}{ Year } & \multirow{2}{*}{$\begin{array}{l}\text { Change } \\
\text { (pp) }\end{array}$} \\
\hline & & 2010 & 2011 & 2012 & 2013 & 2014 & 2015 & 2016 & 2017 & 2018 & \\
\hline SJ212 & $\begin{array}{l}\text { accounting, auditing and } \\
\text { tax consultancy services }\end{array}$ & 0.3 & 0.4 & 0.5 & 0.7 & 0.7 & 0.7 & 0.8 & 0.7 & 0.8 & 0.4 \\
\hline SJ213 & $\begin{array}{l}\text { business consultancy and } \\
\text { public relations services }\end{array}$ & 5.4 & 6.5 & 6.8 & 9.9 & 10.0 & 10.0 & 10.1 & 9.7 & 9.6 & 4.2 \\
\hline SJ22 & $\begin{array}{l}\text { marketing, market } \\
\text { research and public } \\
\text { opinion polling services }\end{array}$ & 1.6 & 2.0 & 2.1 & 2.4 & 2.6 & 2.8 & 3.1 & 3.4 & 3.8 & 2.2 \\
\hline SJ3 & $\begin{array}{l}\text { technical, trade-related, } \\
\text { and other business } \\
\text { services }\end{array}$ & 15.5 & 14.3 & 13.0 & 9.8 & 9.4 & 9.6 & 9.6 & 10.0 & 10.4 & -5.1 \\
\hline SK & $\begin{array}{l}\text { cultural and recreational } \\
\text { services }\end{array}$ & 3.0 & 4.7 & 3.4 & 2.2 & 2.2 & 2.2 & 2.3 & 2.1 & 1.5 & -1.6 \\
\hline
\end{tabular}

Source: Ibidem.

Data on the balance of trade in services are presented in Table 6.5. Their analysis shows that the highest surpluses in trade were reported in 2018 for transport services (PLN 32.8 bn) - including mainly other transport services (PLN 34.8 bn), other business services (PLN 17.2 bn) - especially research and development services, services provided by professionals, and accounting, audit and tax consultancy services, and processing (PLN $15.7 \mathrm{bn}$ ), foreign travel (PLN $15.6 \mathrm{bn}$ ), telecommunication, IT and information services (PLN 13.2 bn) - including mainly IT services (PLN 12.4 bn), and construction services (PLN $6.3 \mathrm{bn}$ ). On the other hand, the highest deficits were witnessed in charges for the use of intellectual property (PLN -11.0 bn) and insurance services (PLN -1.2 bn).

Table 6.5. Balance of Polish trade in services in 2010-2018 (in PLN m)

\begin{tabular}{|l|l|r|r|r|r|r|r|r|r|r|}
\hline \multirow{2}{*}{ Code } & \multicolumn{1}{|c|}{ Service name } & \multicolumn{9}{|c|}{ Year } \\
\cline { 3 - 12 } & & 2010 & 2011 & 2012 & 2013 & 2014 & 2015 & 2016 & 2017 & 2018 \\
\hline S & total services & 13.2 & 21.1 & 25.1 & 32.1 & 37.9 & 45.6 & 60.9 & 76.4 & 92.3 \\
\hline SA & processing & 4.9 & 6.0 & 7.4 & 9.7 & 11.3 & 11.5 & 13.3 & 14.5 & 15.7 \\
\hline SB & repairs & 1.5 & 1.9 & 1.1 & 0.8 & 0.3 & 1.4 & 1.9 & 3.0 & 3.0 \\
\hline SC & transport services & 7.9 & 12.2 & 13.1 & 16.0 & 17.1 & 19.3 & 23.5 & 26.6 & 32.8 \\
\hline SC1 & sea transport & 2.2 & -2.0 & -2.4 & -2.3 & -2.5 & -2.7 & -2.9 & -3.4 & -3.7 \\
\hline SC2 & air transport & 0.1 & 0.9 & 1.1 & 1.7 & 0.5 & 0.2 & 0.4 & 1.2 & 1.7 \\
\hline \multirow{2}{*}{ SC3 } & $\begin{array}{l}\text { other transport services } \\
\text { (except sea and air } \\
\text { transport) }\end{array}$ & 10.1 & 13.4 & 14.4 & 16.8 & 19.1 & 22.0 & 26.0 & 28.9 & 34.8 \\
\hline
\end{tabular}




\begin{tabular}{|c|c|c|c|c|c|c|c|c|c|c|}
\hline \multirow{2}{*}{ Code } & \multirow{2}{*}{ Service name } & \multicolumn{9}{|c|}{ Year } \\
\hline & & 2010 & 2011 & 2012 & 2013 & 2014 & 2015 & 2016 & 2017 & 2018 \\
\hline $\mathrm{SC} 3 \mathrm{C}$ & $\begin{array}{l}\text { other transport services } \\
\text { (except sea and air } \\
\text { transport), including road } \\
\text { transport }\end{array}$ & 7.3 & 9.9 & 10.5 & 12.4 & 14.3 & 16.0 & 18.4 & 19.9 & 23.4 \\
\hline SC4 & postal and courier services & -0.1 & -0.1 & -0.1 & -0.2 & -0.1 & -0.1 & 0.0 & -0.2 & 0.0 \\
\hline SD & foreign travel & 3.0 & 6.6 & 7.2 & 8.0 & 9.4 & 9.5 & 11.8 & 14.7 & 15.6 \\
\hline SE & construction services & 1.8 & 2.7 & 2.5 & 2.7 & 2.9 & 1.8 & 4.8 & 5.7 & 6.3 \\
\hline SF & insurance services & -1.0 & -0.9 & -1.4 & -1.2 & -1.9 & -1.2 & -1.4 & -0.8 & -1.2 \\
\hline SG & financial services & -2.9 & -3.2 & -2.9 & -1.4 & -1.3 & -1.2 & -1.2 & -0.1 & -0.2 \\
\hline $\mathrm{SH}$ & $\begin{array}{l}\text { charges for the use of } \\
\text { intellectual property }\end{array}$ & -6.1 & -6.3 & -6.8 & -7.5 & -8.2 & -7.6 & -8.9 & -9.7 & -11.0 \\
\hline SH1 & $\begin{array}{l}\text { charges for the use of } \\
\text { intellectual property, } \\
\text { including franchise and } \\
\text { trademark fee }\end{array}$ & -0.9 & -1.6 & -2.8 & -3.9 & -3.8 & -3.8 & -4.9 & -5.0 & -5.3 \\
\hline SI & $\begin{array}{l}\text { telecommunication, IT and } \\
\text { information services }\end{array}$ & -0.6 & 0.6 & 1.3 & 1.8 & 3.9 & 6.2 & 8.6 & 10.3 & 13.2 \\
\hline SI1 & telecommunication services & -0.2 & 0.0 & -0.2 & -0.3 & -0.3 & -0.5 & 0.0 & -0.6 & 0.3 \\
\hline $\mathrm{SI} 2$ & IT services & -0.2 & 0.4 & 1.4 & 2.0 & 3.8 & 6.2 & 8.1 & 10.4 & 12.4 \\
\hline $\mathrm{SI} 3$ & information services & -0.1 & 0.2 & 0.1 & 0.1 & 0.4 & 0.5 & 0.6 & 0.6 & 0.5 \\
\hline SJ & other business services & 6.9 & 5.0 & 6.5 & 4.8 & 6.1 & 7.2 & 9.1 & 13.0 & 17.2 \\
\hline SJ1 & $\begin{array}{l}\text { research and development } \\
\text { services }\end{array}$ & 1.2 & 1.6 & 1.7 & 1.7 & 2.4 & 2.9 & 3.0 & 4.0 & 5.0 \\
\hline SJ2 & $\begin{array}{l}\text { services provided by } \\
\text { professionals }\end{array}$ & 3.1 & 2.6 & 3.1 & 1.4 & 1.6 & 2.1 & 3.7 & 5.5 & 8.2 \\
\hline SJ21 & $\begin{array}{l}\text { legal, accounting, } \\
\text { management and public } \\
\text { relations services }\end{array}$ & -0.7 & -1.1 & -0.6 & -2.3 & -2.0 & -1.7 & -0.1 & 2.1 & 4.1 \\
\hline SJ211 & legal services & 0.3 & 0.3 & 0.3 & 0.4 & 0.3 & 0.3 & 0.5 & 0.6 & 0.7 \\
\hline SJ212 & $\begin{array}{l}\text { accounting, auditing and tax } \\
\text { consultancy services }\end{array}$ & 1.6 & 1.7 & 2.1 & 2.6 & 3.0 & 3.8 & 4.9 & 6.2 & 7.8 \\
\hline SJ213 & $\begin{array}{l}\text { business consultancy and } \\
\text { public relations services }\end{array}$ & -2.6 & -3.0 & -3.1 & -5.3 & -5.3 & -5.8 & -5.5 & -4.7 & -4.4 \\
\hline SJ22 & $\begin{array}{l}\text { marketing, market research } \\
\text { and public opinion polling } \\
\text { services }\end{array}$ & 3.8 & 3.6 & 3.7 & 3.8 & 3.6 & 3.8 & 3.8 & 3.5 & 4.1 \\
\hline SJ3 & $\begin{array}{l}\text { technical, trade-related, and } \\
\text { other business services }\end{array}$ & 2.5 & 0.9 & 1.6 & 1.8 & 2.1 & 2.2 & 2.4 & 3.5 & 4.0 \\
\hline SK & $\begin{array}{l}\text { cultural and recreational } \\
\text { services }\end{array}$ & -1.9 & -3.1 & -2.4 & -1.2 & -1.2 & -1.0 & -0.3 & -0.3 & 0.9 \\
\hline \multicolumn{2}{|c|}{ Grand total } & 45.5 & 64.4 & 78.1 & 92.4 & 113.3 & 140.7 & 191.0 & 243.1 & 303.2 \\
\hline
\end{tabular}

Source: Ibidem. 


\subsection{Revealed Comparative Advantages in Trade in Services}

Competitive advantages in foreign trade in services can be additionally analyzed with the use of RCA (revealed comparative advantage) indices. In the analysis presented in this chapter, they are calculated using a logarithmic formula which is a modified version of the original formula by Balassa [1965]. The logarithmic RCA is calculated according to the following formula:

$$
R C A=\ln \left(\frac{x_{i j}^{K}}{m_{i j}^{K}} / \frac{X_{j}^{K}}{M_{j}^{K}}\right),
$$

where $x_{i j}^{K}$ is the exports of sector $i$ from country $K$ to country or group of countries $j, m_{i j}^{K}$ is the exports of sector $i$ from country $K$ to country or group of countries $j, X_{j}^{K}$ denotes the total exports of country $K$ to country or group of countries $j$, while $M_{j}^{K}$ stands for the global imports of country $K$ from country or group of countries $j$.

An RCA value may be either greater or less than zero. If it is greater than zero, it indicates a comparative advantage and describes its intensity at the same time. An RCA less than zero means a comparative disadvantage, a feature that may be more or less intensive. The logarithmic formula makes it possible to preserve the symmetry of positive and negative indicators ranging around zero [Misala, 2007].

Data on the RCA index values for trade in different services are presented in Table 6.6. Their analysis shows that in 2018 Poland achieved comparative advantages in processing (1.96), accounting, audit and tax consultancy services (1.56), research and development services (1.21), construction services (1.03), other transport services (0.46), legal services (0.44), and IT services (0.25). At the same time, the highest comparative disadvantages were recorded for charges for the use of intellectual property $(-2.24)$, sea transport $(-1.49)$, insurance services $(-1.04)$, as well as business consultancy and public relations $(-0.80)$, and financial services $(-0.51)$.

Table 6.6. Indicators of revealed comparative advantages (RCA) in Polish trade in services in 2010-2018

\begin{tabular}{|l|l|r|r|r|r|r|r|r|r|r|r|}
\hline \multirow{2}{*}{ Code } & \multirow{2}{*}{ Service name } & \multicolumn{7}{|c|}{ Year } & \multirow{2}{*}{$\begin{array}{c}\text { Change } \\
\text { (pp) }\end{array}$} \\
\cline { 3 - 12 } & & 2010 & 2011 & 2012 & 2013 & 2014 & 2015 & 2016 & 2017 & 2018 \\
\hline SA & processing & 2.49 & 2.24 & 2.66 & 2.32 & 2.24 & 1.85 & 1.97 & 1.98 & 1.96 & -0.53 \\
\hline SB & repairs & 1.07 & 1.15 & 0.70 & 0.01 & -0.21 & 0.08 & 0.09 & 0.18 & 0.08 & 0.99 \\
\hline SC & transport services & 0.22 & 0.27 & 0.24 & 0.28 & 0.24 & 0.23 & 0.21 & 0.17 & 0.18 & -0.04 \\
\hline SC1 & sea transport & -1.25 & -1.13 & -1.16 & -1.17 & -1.15 & -1.27 & -1.32 & -1.41 & -1.49 & -0.24 \\
\hline SC2 & air transport & -0.10 & 0.06 & 0.09 & 0.18 & -0.18 & -0.27 & -0.30 & -0.24 & -0.24 & -0.14 \\
\hline
\end{tabular}




\begin{tabular}{|c|c|c|c|c|c|c|c|c|c|c|c|}
\hline \multirow{2}{*}{ Code } & \multirow{2}{*}{ Service name } & \multicolumn{9}{|c|}{ Year } & \multirow{2}{*}{$\begin{array}{l}\text { Change } \\
\text { (pp) }\end{array}$} \\
\hline & & 2010 & 2011 & 2012 & 2013 & 2014 & 2015 & 2016 & 2017 & 2018 & \\
\hline SC3 & $\begin{array}{l}\text { other transport } \\
\text { services (except sea } \\
\text { and air transport) }\end{array}$ & 0.46 & 0.48 & 0.44 & 0.48 & 0.50 & 0.52 & 0.50 & 0.45 & 0.46 & 0.00 \\
\hline $\mathrm{SC} 3 \mathrm{C}$ & $\begin{array}{l}\text { other transport } \\
\text { services (except sea } \\
\text { and air transport), } \\
\text { including road } \\
\text { transport }\end{array}$ & 0.47 & 0.49 & 0.46 & 0.49 & 0.52 & 0.52 & 0.47 & 0.41 & 0.40 & -0.07 \\
\hline SC4 & $\begin{array}{l}\text { postal and courier } \\
\text { services }\end{array}$ & -0.38 & -0.39 & -0.46 & -0.65 & -0.47 & -0.51 & -0.42 & -0.71 & -0.49 & -0.11 \\
\hline SD & foreign travel & -0.02 & 0.05 & 0.02 & -0.01 & 0.01 & -0.04 & -0.05 & -0.06 & -0.09 & -0.07 \\
\hline SE & $\begin{array}{l}\text { construction } \\
\text { services }\end{array}$ & 0.49 & 0.64 & 0.46 & 0.45 & 0.49 & 0.07 & 0.85 & 1.00 & 1.03 & 0.54 \\
\hline SF & insurance services & -1.03 & -0.75 & -1.16 & -1.02 & -1.49 & -0.87 & -0.94 & -0.81 & -1.04 & 0.00 \\
\hline SG & financial services & -1.01 & -1.13 & -1.02 & -0.73 & -0.68 & -0.68 & -0.73 & -0.46 & -0.51 & 0.50 \\
\hline $\mathrm{SH}$ & $\begin{array}{l}\text { charges for the } \\
\text { use of intellectual } \\
\text { property }\end{array}$ & -2.39 & -2.37 & -2.52 & -2.42 & -2.43 & -2.08 & -2.17 & -2.13 & -2.24 & 0.15 \\
\hline $\mathrm{SH} 1$ & $\begin{array}{l}\text { charges for the } \\
\text { use of intellectual } \\
\text { property, including } \\
\text { franchise and } \\
\text { trademark fee }\end{array}$ & -1.48 & -1.82 & -2.60 & -2.80 & -2.43 & -2.85 & -3.26 & -2.97 & -3.32 & -1.84 \\
\hline SI & $\begin{array}{l}\text { telecommunication, } \\
\text { IT and information } \\
\text { services }\end{array}$ & -0.22 & -0.12 & -0.06 & -0.07 & 0.06 & 0.15 & 0.16 & 0.13 & 0.15 & 0.37 \\
\hline SI1 & $\begin{array}{l}\text { telecommunication } \\
\text { services }\end{array}$ & -0.27 & -0.20 & -0.34 & -0.45 & -0.47 & -0.67 & -0.38 & -0.70 & -0.36 & -0.09 \\
\hline $\mathrm{SI} 2$ & IT services & -0.18 & -0.12 & 0.00 & 0.01 & 0.13 & 0.27 & 0.24 & 0.29 & 0.25 & 0.44 \\
\hline SI3 & $\begin{array}{l}\text { information } \\
\text { services }\end{array}$ & -0.42 & 0.14 & -0.05 & -0.11 & 0.29 & 0.26 & 0.08 & -0.02 & -0.09 & 0.33 \\
\hline SJ & $\begin{array}{l}\text { other business } \\
\text { services }\end{array}$ & 0.14 & 0.00 & 0.02 & -0.09 & -0.09 & -0.10 & -0.13 & -0.12 & -0.11 & -0.24 \\
\hline SJ1 & $\begin{array}{l}\text { research and } \\
\text { development } \\
\text { services }\end{array}$ & 1.16 & 1.15 & 1.06 & 0.81 & 0.96 & 1.02 & 0.85 & 1.13 & 1.21 & 0.05 \\
\hline SJ2 & $\begin{array}{l}\text { services provided } \\
\text { by professionals }\end{array}$ & 0.23 & 0.05 & 0.05 & -0.17 & -0.19 & -0.20 & -0.20 & -0.18 & -0.15 & -0.38 \\
\hline SJ21 & $\begin{array}{l}\text { legal, accounting, } \\
\text { management and } \\
\text { public relations } \\
\text { services }\end{array}$ & -0.26 & -0.34 & -0.28 & -0.48 & -0.45 & -0.44 & -0.38 & -0.30 & -0.24 & 0.02 \\
\hline SJ211 & legal services & 0.45 & 0.24 & 0.31 & 0.40 & 0.24 & 0.20 & 0.32 & 0.44 & 0.44 & -0.01 \\
\hline SJ212 & $\begin{array}{l}\text { accounting, } \\
\text { auditing and } \\
\text { tax consultancy } \\
\text { services }\end{array}$ & 1.70 & 1.45 & 1.38 & 1.25 & 1.24 & 1.35 & 1.35 & 1.49 & 1.56 & -0.15 \\
\hline
\end{tabular}




\begin{tabular}{|c|c|c|c|c|c|c|c|c|c|c|c|}
\hline \multirow{2}{*}{ Code } & \multirow{2}{*}{ Service name } & \multicolumn{9}{|c|}{ Year } & \multirow{2}{*}{$\begin{array}{c}\text { Change } \\
\text { (pp) }\end{array}$} \\
\hline & & 2010 & 2011 & 2012 & 2013 & 2014 & 2015 & 2016 & 2017 & 2018 & \\
\hline SJ213 & $\begin{array}{l}\text { business } \\
\text { consultancy and } \\
\text { public relations } \\
\text { services }\end{array}$ & -0.86 & -0.81 & -0.75 & -0.93 & -0.90 & -0.94 & -0.89 & -0.83 & -0.80 & 0.06 \\
\hline SJ22 & $\begin{array}{l}\text { marketing, market } \\
\text { research and public } \\
\text { opinion polling } \\
\text { services }\end{array}$ & 1.15 & 0.85 & 0.77 & 0.63 & 0.50 & 0.43 & 0.26 & 0.11 & 0.06 & -1.09 \\
\hline SJ3 & $\begin{array}{l}\text { technical, trade- } \\
\text { related, and other } \\
\text { business services }\end{array}$ & 0.03 & -0.13 & -0.10 & -0.11 & -0.11 & -0.14 & -0.20 & -0.21 & -0.24 & -0.27 \\
\hline SK & $\begin{array}{l}\text { cultural and } \\
\text { recreational } \\
\text { services }\end{array}$ & -1.25 & -1.30 & -1.28 & -0.95 & -0.93 & -0.77 & -0.49 & -0.51 & -0.14 & 1.12 \\
\hline
\end{tabular}

Source: Ibidem.

\subsection{COVID-19 and Trade in Services}

The economic effects of the COVID-19 pandemic require additional comment, as they will soon be reflected in Polish trade in services. As Baldwin and Weder di Mauro [2020] point out, fiscal and monetary stimuli and a severe global economic recession are likely to develop in the wake of the pandemic, which will have a major impact on international trade. The pandemic-induced economic crisis will spread through different channels. According to Keogh-Brown et al. [2009], Prager et al. [2016], Levi et al. [2017] and McKibbin and Sidorenko [2006], they will include reduction of the supply of labor (deaths, diseases, school closures, avoiding going to work), lower consumption (illness, closure of shops, restaurants, travel and transport restrictions, etc.), increased spending on healthcare and social assistance, reduced production level (absence), supply chain disruptions, increased risk, as well as reluctance and expectations from investors (affecting financial markets and all economies).

Studies on the impact of COVID-19 on trade in services are still few and far between. Gruszczyński [2020] points out, however, that after the temporary shock caused by the pandemic, international trade will return to its former shape, although a change in long-term trends in its structure cannot be ruled out. Unfortunately, at the time of preparing this study, no statistics were available on trade in particular types of services in Q2 2020, so it is currently difficult to assess the scale of the impact of the pandemic on Polish trade in services. Yet, at this point, it is worth looking at the potential short- and long-term effects of the pandemic on trade in services presented by the WTO [2020]. According to the organization's report, due to the proliferation of the 
COVID-19 pandemic and its aftermath, many service industries have come under pressure from declining demand, or even the inability to provide services. When assessing the direct sensitivity of different types of services to the COVID-19 pandemic and its effects, it should be pointed out that they have had a particularly strong impact on trade in services that require physical contact between suppliers and consumers. This means that the pandemic has affected to varying degrees the services provided in the various modes described in the GATS ( 1 - cross-border sales, 2 - provision and consumption of services abroad, 3 - commercial presence abroad, and 4 - physical presence of service providers). Services provided in Modes 2 and 4, as well as 3 according to the GATS classification, have proved particularly sensitive to the effects of the pandemic. Interestingly, the pandemic can benefit services provided in Mode 1, i.e. cross-border sales (cross-border provision of services from the territory of one state to the territory of another state)

An attempt can be made to translate the effects of the spread of COVID-19 into specific types of services. One of the service industries that was worst affected by the pandemic was that of transport services. Mobility reduction and restrictions on border crossings have therefore had a significant impact on trade in transport services and, consequently, also on international trade in goods. The restrictions in force have also affected road transport, sea transport, and, in particular, air transport. In addition, the resumption of border controls has resulted in significant reductions and delays in cross-border freight transport. The industries related to tourism services have also been strongly affected by the restrictions. In their case, it should be pointed out that they are largely based on trade in Mode 2, but restrictive rules on domestic travel and restrictions for hotels and food services during the pandemic have also affected the local tourist industry, which are provided through commercial presence (Mode 3). Undertakings providing distribution services (intermediary services, wholesale services, retail trade services, and franchising) also suffered from the pandemic, as social distancing involved the closure of shops considered non-essential. These restrictions have proved particularly acute for the provision of services in Mode 3 (commercial presence).

At the same time, it should be noted that many industries, in particular those related to Mode 1 of service provision (cross-border sales), may potentially benefit from the pandemic. This is particularly the case with those professions where remote work can be carried out and the results can be transmitted to the employer via the Internet. Thus, demand for ICT services and related infrastructure may increase. It can therefore be concluded that the effects of the pandemic on services provided online will not be as negative as for industries requiring physical proximity. What is more, they may derive certain benefits from the current situation. Industries potentially 
benefiting from the pandemic also include telemedicine and financial services. In the latter case, this concerns, in particular, financial intermediaries involved in providing assistance to industries affected by the spread of COVID-19.

Summing up the above considerations on the impact of COVID-19 on Polish trade in services, it should be noted that it is now difficult to estimate its scale. However, it is likely that trade in transport, tourism and distribution services will suffer the most in the current situation. However, many industries can benefit from the pandemic in the long term, in particular ICT, telemedicine, and financial services. These predictions can be verified fairly soon on the basis of updated data on international trade in services, which are, however, published with a very long delay.

\subsection{Summary and Conclusions}

To sum up the analyses presented in this chapter, it should be pointed out that the competitiveness of the Polish service sector in foreign trade, as measured by changes in the value of exports and imports and the balance of trade in services, improved steadily between 2010 and 2019. This was reflected in a gradual faster increase in the value of Polish exports than imports of services, which resulted in a smooth increase in the positive balance of trade in services from PLN 13.2 bn in 2010 to PLN 108.2 bn 2018. It should be noted that in 2018 the value of exports of services from Poland represented $258.5 \%$ of the value of 2010 exports, the corresponding value of imports was only $179.4 \%$, while the excess value of service exports over imports represented as much as $819.7 \%$ of the 2010 value. It is also noteworthy that Poland's main trading partners in services were EU member states, as well as other developed countries, and countries of Eastern Europe and Asia.

The analysis of the sectoral structure of Polish foreign trade could not cover 2019, as the relevant data are published with a long delay and only data up to 2018 were available at the time of preparing this study. Their analysis indicates that the largest surpluses in Polish foreign trade in services were achieved in trade in transport services, other business services, in the field of processing, foreign travel, trade in IT services, as well as construction services. On the other hand, the largest deficits in trade in services were recorded in charges for the use of intellectual property and insurance services. Similar results were obtained from an analysis of revealed comparative advantages. Their analysis showed that Poland achieved highest comparative advantages in processing, accounting, audit and tax consultancy services, research and development services, construction services, other transport services, legal services, and IT services. At the same time, the highest comparative disadvantages were recorded for 
charges for the use of intellectual property, sea transport, insurance services, as well as business consultancy and public relations services, and financial services.

Finally, it should be pointed out that at the end of Q1 2020, trade in services came under pressure from the COVID-19 pandemic, which could significantly change the structure and balance of trade in services that we have seen in recent years. While it is currently difficult to predict how specific numbers and proportions will change, the industries expected to be most affected by the pandemic will be trade in transport, tourism and distribution services. In contrast, ICT, telemedicine, and financial services may benefit in this case.

\section{Bibliography}

Balassa, B. [1965], Trade Liberalization and Revealed Comparative Advantage, "Manchester School of Economic and Social Studies", Vol. 33, pp. 99-123.

Baldwin R., Weder di Mauro, B. [2020], Mitigating the COVID economic crisis: act fast and do whatever, CEPR Press, London.

Gruszczynski, L. [2020], The Covid-19 Pandemic and International Trade: Temporary Turbulences or Paradigm Shift?, "European Journal of Risk Regulation", pp. 1-6.

Keogh-Brown, M.R. et al. [2009], The possible macroeconomic impact on the UK of an influenza pandemic, "Health Economics", Vol. 19(11), pp. 1345-1360.

McKibbin, W.J., Sidorenko, A.A. [2006], Global macroeconomic consequences of pandemic influenza, Lowy Institute for International Policy, February, https://www.lowyinstitute. org/publications/global-macroeconomic-consequences-pandemic-influenza (10.03.2020).

Prager, F., Wei, D., Rose, A. [2016], Total economic consequences of an influenza outbreak in the United States, "Risk Analysis", Vol. 37(1), pp. 4-19.

WTO [2020], Trade in services in the context of Covid-19, May, https://www.wto.org/english/ tratop_e/covid19_e/services_report_e.pdf (8.06.2020). 
Chapter 7

\section{The Link between Foreign Direct Investment in Services and the Competitiveness of the Polish Economy in the Service Sector. A Comparative Analysis vis-à-vis the Visegrad Group Economies}

Tomasz M. Napiórkowski

\subsection{Introduction}

Foreign Direct Investment (FDI) ${ }^{1}$ is subject to analyses presented in many research papers. Their significance from the point of view of both, the global economy and individual national economies has been growing with the progress of globalization, which is driven by the activities of multinational corporations. Despite the existing discrepancies in research results [e.g., Napiórkowski, 2017a], the belief prevails among researchers that FDI brings tangible benefits to the host country. They can be subjected to different classifications, but regardless of the division adopted, the authors point to FDI effects such as an increase in wages or employment [Javorcik, 2015, pp. 87-88], accumulation of physical capital [Lo, Hong and Li, 2016, p. 107], technology flow to domestic companies [Svedin and Stage, 2016, p. 10], and knowhow transfer [Wang and Wu, 2016, pp. 904-905]. In view of the above factors, which confirm the impact of FDI on the economic growth of the host country, the absorption of FDI is also positively related to the international competitiveness of the host country (e.g., such a link has been demonstrated for Poland by Napiórkowski, 2017b and for China by Zhang, 2015).

While there is a significant number of works discussing the impact of FDI on the host country, a small part of them focus on FDI in the service sector and even fewer studies in this area concern the Visegrad Group countries (see, e.g., Armenise, Giovannetti and Santoni, 2015; Sass, Gál and Juhász, 2018). The study described in this

\footnotetext{
1 The term "direct foreign investment" also exists in the nomenclature in use.
} 
chapter complements the existing literature by providing insight into an identified research gap.

On the basis of a preliminary analysis of the literature, a response to the research question on whether there is a link between FDI activity in the service sector and the international competitiveness of the Polish economy in this area has been constructed in the form of a research hypothesis: there exists a link between FDI activity in services and the international competitiveness of the Polish economy in the service sector. The purpose of the study presented in this chapter is to test this hypothesis.

Due to the need to operationalize the presented study, data from secondary sources will be analyzed, including those on FDI in the service sector and on the international competitiveness of the sector. The literature on FDI in the service sector, in particular the factors determining this phenomenon and the benefits of hosting FDI in the service sector, will also be taken into account in the study. In the next part, the link between FDI in the service sector and the international competitiveness of the host country's service sector will be subject to empirical verification. To relativize the values of the variables and the conclusions themselves, Poland will be compared to the other members of the Visegrad Group.

\subsection{Development of Foreign Direct Investment in Services in Poland vis-à-vis the Visegrad Group}

The purpose of this part of the report is to present the status quo of FDI in the service sector in Poland and the other Visegrad Group countries.

By analyzing data on FDI in the service sector, a stable increase in the value of FDI stock can be seen, while the value of FDI inflows in the service sector is characterized by significant variance. ${ }^{2}$ The value of FDI inflows in the service sector in 2010 2017 ranged from PLN 6,582.36 m in 2012 to PLN 44,313.11 m in 2016 (Figure 7.1). The average share of FDI inflows in the service sector in the total value of FDI inflows in Poland during the analyzed period was $75,22 \%$. It is worth highlighting that, with the exception of a spike witnessed in 2013 (174.06\%), the reported share of FDI inflows in the service sector remained virtually unchanged over the long term: it was $72.28 \%$ in 2010, 76.94\% in 2016, and 60.29\% in 2017. The share of FDI stock in the service sector in total ZIB stock was even more stable (Figure 7.2). Over the examined period, the analyzed share increased from $59.70 \%$ in 2010 to $60.46 \%$ in 2016 and $60 \%$ in the

2 This observation coincides with the conclusions of the analysis of the literature FDI in the service sector presented later in the chapter. 
following year. The value of FDI stock in the service sector in Poland was characterized by a growing trend (average increase of PLN $9517.4 \mathrm{~m}$ during the year, $R^{2}=65,62 \%$ ); with a maximum value of PLN 454,369.38 $\mathrm{m}$ achieved in 2017.

Figure 7.1. FDI inflows in the service sector and total FDI inflows in Poland (left axis in PLN millions) and the service sector's FDI inflows share in total FDI inflows (right axis in \%) in 2020-2017

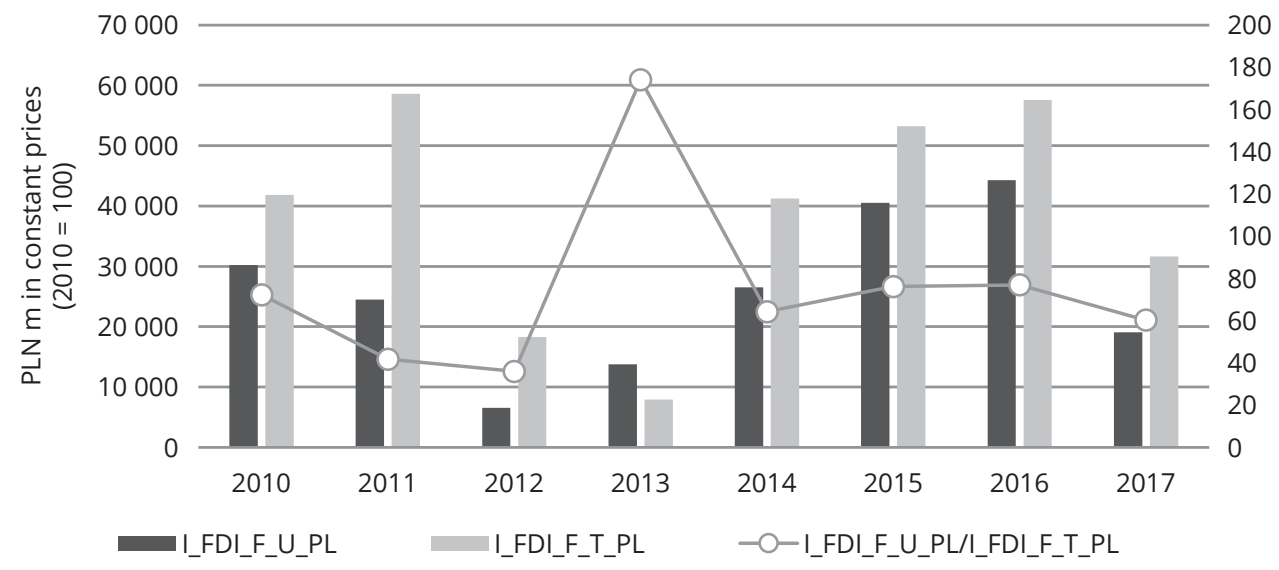

I_FDI_F_U_PL - FDI inflows in the service sector in Poland

I_FDI_T_PL - total FDI inflows in Poland

Source: Own study based on data from NBP [2019] and the World Bank [2019a].

Figure 7.2. FDI stock in the service sector and total FDI stock in Poland (left axis in PLN millions) and the service sector's FDI stock share in total FDI stock (right axis in \%) in 2020-2017

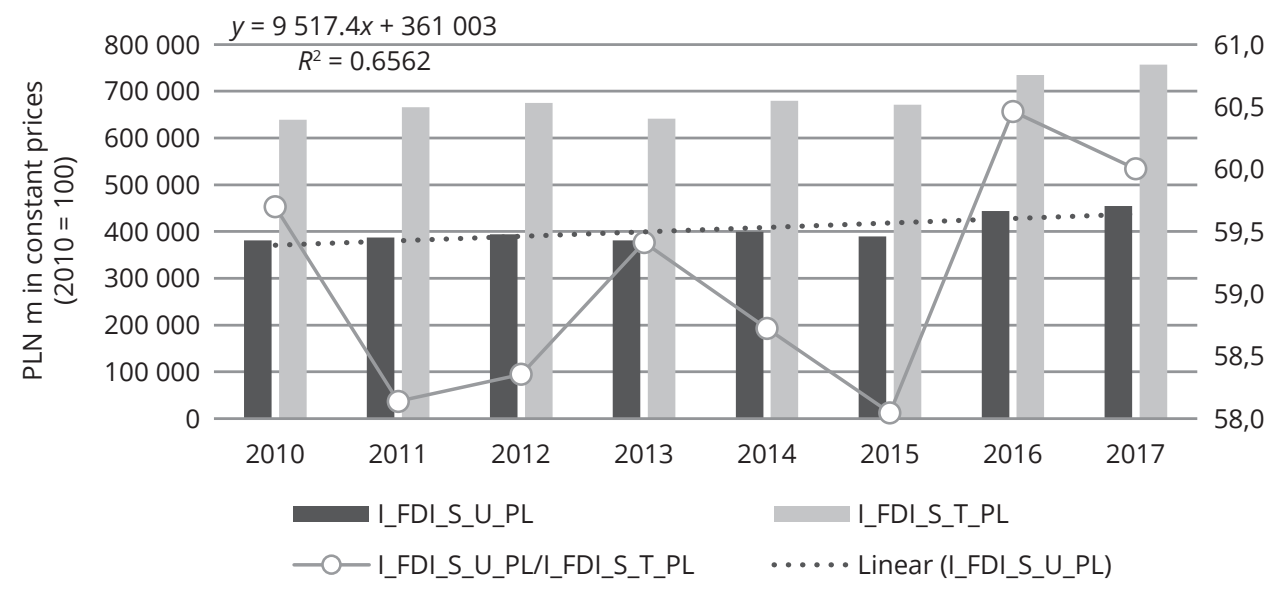

I_FDI_S_U_PL - FDI stock in the service sector in Poland

I_FDI_S_T_PL - total FDI stock in Poland

Source: Own study based on data from NBP [2019] and the World Bank [2019a]. 
Comparing the per capita value of FDI inflows in the service sector in Poland with those observed in the other Visegrad Group countries between 2003 and 20123 , it can be seen that the data analyzed across the four economies were similar (Figure 7.3). The exceptions are: a) a significant increase in the value of FDI inflows in the service sector in the Czech Republic between 2003 and 2005 and b) the increase in the value of the reported inflows in Hungary in 2011. Comparing the analyzed economies on the basis of the average value of FDI inflows in the service sector between 2003 and 2011', it can be seen that Poland (USD 251.91: 47\% of the value of the list leader) ranks last in this respect. Hungary (USD 532.79) leads the way, followed by the Czech Republic (USD 458.53: 86\%), and Slovakia (USD 320.45: 60\%). In the case of FDI stock per capita in services, a much greater variation can be seen between the economies examined (Figure 7.4).

Figure 7.3. FDI inflows per capita in the service sector in the Visegrad Group countries: Czech Republic, Hungary, Poland and Slovakia (left axis in USD) in 2003-2012

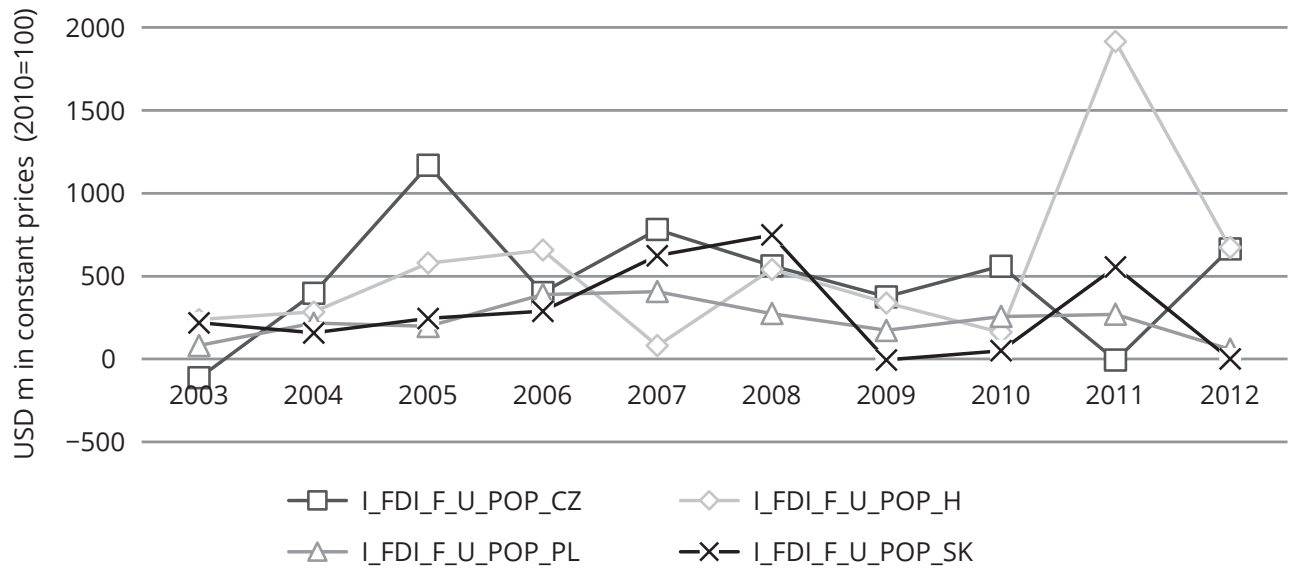

I_FDI_F_U_POP_CZ - FDI inflows per capita in the service sector in the Czech Republic

I_FDI_F_U_POP_H - FDI inflows per capita in the service sector in Hungary

I_FDI_F_U_POP_PL - FDI inflows per capita in the service sector in Poland

I_FDI_F_U_POP_SK - FDI inflows per capita in the service sector in Slovakia

Source: Own study based on data from OECD [2019a] and the World Bank [2019a]; 2019b].

During the entire period examined, Hungary or the Czech Republic led in terms of the FDI stock value, regularly exchanging the leader position. Slovakia came in third

3 While this is already historical data, it is the longest and at the same time the only range of data that comes from a single source, which greatly reduces the possibility of discrepancies in the methods used for data collection and reporting.

4 The year 2012 has been omitted in the calculation of the average value due to the lack of data for Slovakia for that period. 
place, and Poland ranked last. By averaging the time series analyzed (2003-2011), it can be seen that that the average per capita value of FDI stock in the service sector in the Czech Republic is USD 5033.02, in Hungary - USD 4970.61 (99\% of the list leader's value), in Slovakia - USD 3524.32 (70\%), and in Poland only USD 2377.91 (47\%).

Figure 7.4. FDI stock per capita in the service sector in the Visegrad Group countries: Czech Republic, Hungary, Poland and Slovakia (left axis in USD) in 2003-2012

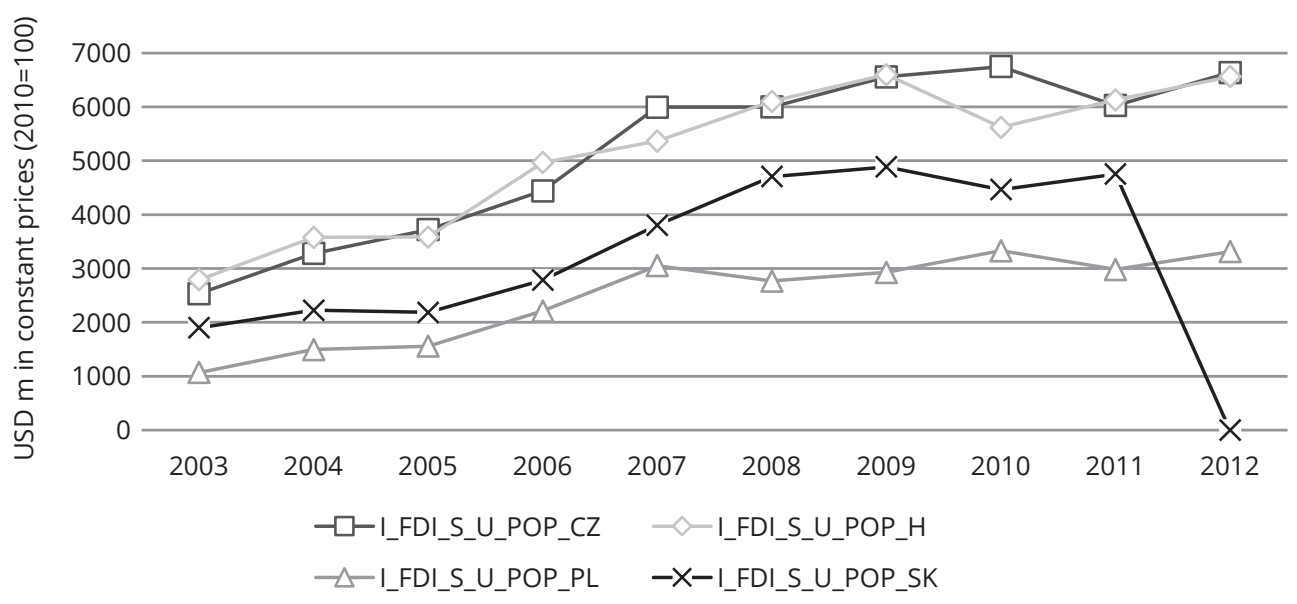

I_FDI_S_U_POP_CZ FDI stock per capita in the service sector in the Czech Republic

I_FDI_S_U_POP_H - FDI inflows per capita in the service sector in Hungary

I_FDI_S_U_POP_PL - FDI stock per capita in the service sector in Poland

I_FDI_S_U_POP_SK - FDI inflows per capita in the service sector in Slovakia

Source: Own study based on data from OECD [2019b] and the World Bank [2019a]; 2019b].

Based on the analysis carried out in this part of the analysis, it can be concluded that: 1) the share of FDI in the service sector in total FDI value in Poland is quite stable; 2) the FDI stock has been increasing; and 3) in 2003-2012, Poland ranked last among the Visegrad Group members in terms of relative attractiveness for FDI in the service sector.

\subsection{Changes in the International Competitiveness of the Polish Economy in Services vis-à-vis the Visegrad Group}

This part of the study presents the results of an analysis of the international competitiveness of the service sector in Poland and in the other countries of the Visegrad Group. 
To illustrate the competitiveness of the service sector, the revealed comparative advantage (RCA) index as proposed by Balassa [1965] has been used. It was recognized as "the canon of research on international competitiveness in international trade and broader international exchange" by Misala [2011, p. 165]. According to the RCA methodology presented also by UNCTAD [2019], an RCA value greater than 1 suggests that the country concerned is a "competitive producer and exporter of that product relative to a country producing and exporting that good at or below the world average" [UNCTAD, 2019].

In 2003-2017, (except 2004, 2005, and 2009), Poland - compared with the other Visegrad Group countries - had the highest RCA values (Figure 7.5). Hungary ranked second, followed by the Czech Republic and Slovakia. However, it should be emphasized that for none of the four analyzed economies the RCA value exceeded 1 . This means that none of the Visegrad Group members had a revealed comparative advantage in the service sector at global level. Another important observation is that the RCA values for the analyzed economies decreased over time. The greatest absolute decrease (0.296) was reported by Slovakia. It was followed by the Czech Republic (with a decrease of 0.272), Hungary (0.264) and Poland (0.204). In 2016-2017, RCA values were increasing in each of the studied countries. The greatest rebound was witnessed in Poland (0.050), followed by Hungary (0.044), Slovakia (0.032), and the Czech Republic (0.025).

Figure 7.5. Revealed comparative advantage (RCA) index for the service sector in the Visegrad Group countries in 2003-2017

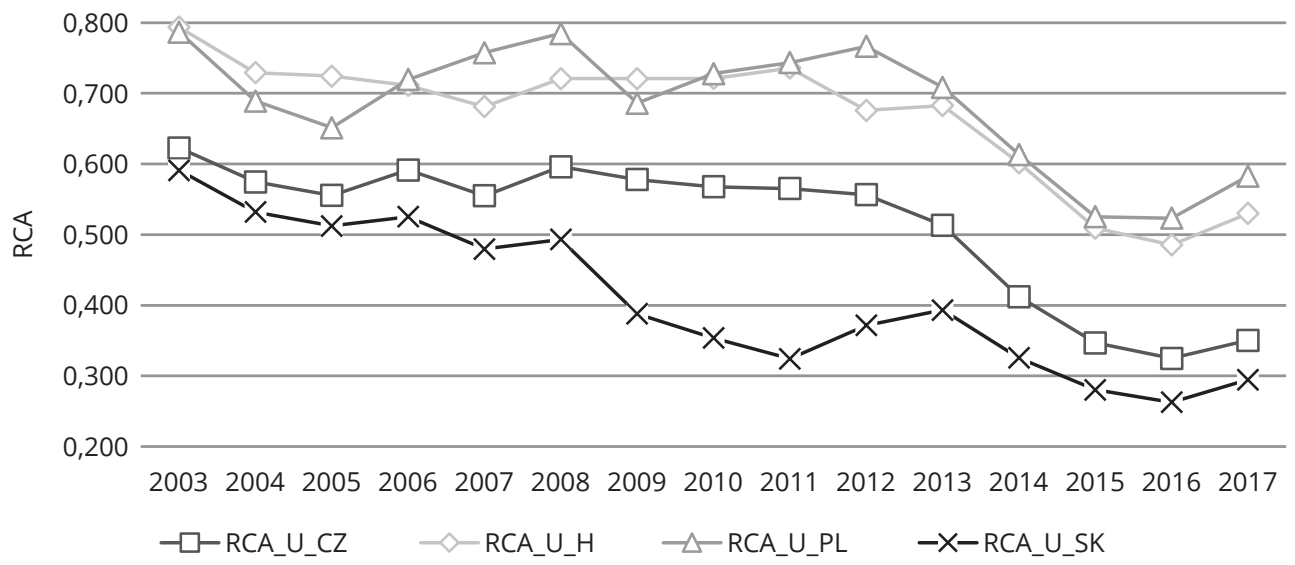

Source: Own study based on data from UN Comtrade [2019]. 


\subsection{Review of the Literature on Foreign Direct Investment in Services and their Impact on the Host Economy}

This part of the chapter presents an analysis of the literature on FDI in the service sector both, from the perspective of its determinants and its impact on the economy of the host country.

In a very extensive study, using data for 57 countries from 1989-2000, Kolstad and Villanger [2008, p. 518] show that in the case of FDI in the service sector the quality of public institutions and democracy in the host country are more important determinants of FDI than investment risk or political stability, while the quality of democracy is of significance only for developing economies. The authors conclude that service FDI is unaffected by trade openness because it is, by assumption, market seeking. In their study, Kolstad and Villanger show that the statistical significance of coefficients assigned to explanatory variables for FDI in the service sector differs depending on the investment area. In the case of the tertiary industries, the determinants of FDI flows are the level of democracy, institutional quality, GDP per capita, and FDI in the secondary sector, i.e. in manufacturing. At the same time, it turned out that other variables taken into account, i.e., political risk (including political stability), economic growth, trade, and inflation, have no statistically significant sign effect on the dependent variable, namely FDI per capita in services [Kolstad and Villanger, 2008, p. 525]. In the case of the financial industry, the statistically significant determinants were: GDP per capita and FDI in the secondary industries [Kolstad and Villanger, 2008, p. 527]. With regard to the business industry, modelling did not provide results allowing concrete conclusions to be drawn, which is indicative of the heterogeneity of the FDI determinants in the service sector across investment areas and services themselves. Explanatory variables for the quality of public institutions (which is of a greater importance in transport than in other services), GDP per capita, and FDI in secondary industries were considered by the authors as FDI determinants in transport [Kolstad and Villanger, 2008, p. 528]. Variables determining the existence of FDI in the service sector in trade are: transparency, openness and democratic accountability and GDP per capita [Kolstad and Villanger, 2008, p. 529].

In her study, Riedl [2010] made an attempt to show that FDI related to the manufacturing sector and FDI in the service sector are conditional upon different factors, and the determinants, which are common to both these categories produce different effects in the short and long term. By means of econometric modelling, the author shows that FDI related to the manufacturing sector needs more time to respond to stimuli than FDI in the service sector. This may result from high capital expenditure often needed 
in manufacturing, the scale of which is usually much smaller for services [Riedl, 2010, p. 753]. Like authors of other works described in this chapter, Riedl [2010, p. 754] also notes that labor costs have no impact on FDI in the service sector and that it is more (than manufacturing) susceptible to market size. However, the latter phenomenon was observed only in the short term. Changes in location factors translate into service FDI already within one year, which, as the author emphasizes, makes FDI in the service sector more susceptible to public sector or law-makers' impacts [Riedl, 2010, p. 756]. In a comment on the insignificance of labor costs as a FDI determinant in the service sector, Riedl attributes this phenomenon to a low potential of foreign trade in services, which may change with the development of communication technology [Riedl, 2010, p. 756].

Ramasamy and Yeung [2010] also notice the role of the market size, but they put more emphasis on the fact that while labor costs in the case of services also do matter, foreign investors prefer economies with a greater human capital stock [Ramasamy and Yeung, 2010, p. 588]. In addition, the authors point to such variables determining FDI in the service sector as capital cost, infrastructure (transport and communication), openness to FDI (e.g., through the privatization and acquisition process), and the general investment risk. In their considerations, they also take into account the mass effect occurring when new FDI is determined by FDI already located in the host, which allows good business operating conditions to be provided for new investors [Ramasamy and Yeung, 2010, pp. 588-589]. The authors concluded that "manufacturing FDI is the single most important determinant of services FDI", which means that legislators can attract FDI in the service sector also indirectly by attracting FDI related to the manufacturing sector [Ramasamy and Yeung, 2010, p. 592].

At the beginning of their article, Jones and Wren [2016] emphasize the role of FDI in the service sector, noting that it is responsible for more than half of FDI flows in the world [Jones and Wren, 2016, p. 1981]. Having carried out a regional analysis of FDI in services and manufacturing in the United Kingdom, the authors conclude that FDI in the service sector focus on regions with a high market potential [Jones and Wren, 2016, pp. 1981-1982], which corresponds with conclusions from other studies cited in this review. This conclusion also confirms the hypothesis of the heterogeneity of FDI determinants in the service sector and in the manufacturing sector. Further on, Jones and Wren [2016] claim that FDI in the service sector is made more dynamically than FDI in the manufacturing sector, which may arise from service FDI's greater reliance on new investment rather than reinvestment [Jones and Wren, 2016, p. 1992]. Finally, the authors point out that in the case of FDI policy (as well as pro-growth policy tackling the uniform development challenge), the key issue is that service FDI is located in the major urban areas, which translates into distribution of employment Jones and Wren, 2016, p. 1992] 
In their study on service FDI in Malaysia, Yean, Kam and Noh [2018], used an econometric model taking into account panel data to identify the determinants of inward FDI in services. In selecting explanatory variables, the authors of the study used Dunning's location theory. Investment motives related to market-seeking are represented in this model by GDP of the sector concerned; resource- and asset-seeking motives - by an increase in the number of workers with higher education; efficiencyand asset-seeking - by communication infrastructure (ICT); efficiency-seeking motive - by the level or regulatory restrictiveness; and resource- and efficiency-seeking - by the cost of labor (Yean, Kam and Noh, 2018, pp. 220-222). Among the presented possible determinants, only a coefficient related to regulation variable turned out to be statistically different from zero. This way, the authors of the study came to the conclusion that multinational corporations undertaking FDI in the service sector are interested in educated and not cheap labor [Yean, Kam and Noh, 2018, p. 224].

Ishikawa, Morita and Mukunoki [2010] emphasize that the role of FDI in the service sector is complementary to trade liberalization. The authors show that in the case of outsourcing post-production services by foreign firms, entities awarded a contract may (seeking higher profits) try to increase the price of the services provided. The recommended solution in this case is increased liberalization of service FDI, which is expected to reduce per-unit costs [Ishikawa, Morita and Mukunoki, 2010, p. 82]. Summing up their conclusions from the perspective of implications for pro-growth policy, the authors note that "a sufficiently large reduction of the fixed cost for service FDI converts a welfare-reducing trade liberalization into a welfare-enhancing trade liberalization." [Ishikawa, Morita and Mukunoki, 2010, p. 80].

In an econometric study on the impact of FDI in services on total factor productivity (TFP) in Chile, Fernandes and Paunov [2012] aggregate the impact of FDI on the service sector to four elements: price reductions (e.g., as a result of competition), quality improvements (e.g., through better technology and knowledge), increased variety (e.g., through the provision of new services, provision of services to new customers), and spillovers, (e.g., through uncontrolled dispersion of management or marketing know-how) [Fernandes and Paunov, 2012, p. 307]. The results of this study show that service FDI has a positive impact on TFP in the host country [Fernandes and Paunov, 2012, p. 311], but this relationship may take various forms across industries, which may be linked to FDI in knowledge-based services and its impact on innovation [Fernandes and Paunov, 2012, p. 316]. Stimulating innovation in the manufacturing sector through FDI in the service sector should thus make it easier for firms lagging behind in terms of technological advancement to catch-up with leading manufacturers. Interestingly, the authors confirm that the more "backward" a firm is, the more it can learn and improve [Fernandes and Paunov, 2012, p. 317]. 
Armenise, Giovannetti and Santoni [2015] note that service FDI can have a positive effect on manufacturing activities, e.g., through knowledge spillovers. Knowledge spillovers will tend to take place within a given value chain (vertical spillovers) rather than between chains (horizontal spillovers), which can result from the fact that foreign firms fear knowledge leakage to competitive enterprises [Armenise, Giovannetti and Santoni, 2015, p. 198]. Both in their conclusions and a review of the literature, the authors of this study point to a significant role of liberalization of service FDI as a determinant of the impact of FDI on the host country. Based on their calculations, Armenise, Giovannetti and Santoni [2015] conclude that FDI in the service sector has a positive effect on TFP in the host country and on the competitiveness of the whole economy. Consequently, the economic performance of firms improves, but the scale of this phenomenon depends on the technological advancement of the sector concerned and the availability of skilled labor [Armenise, Giovannetti and Santoni, 2015, p. 211].

As noted in the UNCTAD report [2018], while the impact of service FDI on employment is positive and supported by a growth of export-related services, the effect is weaker than in other sectors [UNCTAD, 2018, p. 20]. Like other works analyzed in this chapter, the UNCTAD report emphasizes that the scale of service FDI impact on employment may differ between sectors, which may also be a negative impact [UNCTAD, 2018, p. 21].

Examining the Visegrad Group countries, Sass, Gál and Juhász [2018] demonstrated in their literature review that: 1) services are the main FDI target in the group of economies concerned; 2) few analyses are available describing the impact of FDI in the service sector on the host country; 3) the identified positive impact is in fact more modest than suggested by politicians, lobbying groups, and firms; 4) the impact of FDI in the service sector on the development of knowledge and innovation in the analyzed group is very limited, having the strongest effect on employment [Sass, Gál and Juhász, 2018, pp. 654-655]. The results obtained by the authors show that the impact of FDI on employment and exports in selected services varies between the analyzed countries, which may be associated with the fact that four examined economies differ in terms of specialization in services [Sass, Gál and Juhász 2018, p. 667].

Doytch and Uctum [2019] demonstrated a positive and statistically significant impact of FDI in the financial service sector on economic growth of the host country. They can contribute to the development of the manufacturing sector by supporting firms, which have no access to financial markets. At the same time, the authors of the study draw attention to FDI in the trade service sector, which has a negative impact on the host economy. This results from the fact that firms making FDI in the service sector create competition to local firms (e.g., by achieving - due to their size 
- substantial economies of scale). While FDI in the service sector has a positive impact on the service sector in the host country, their spillovers in the manufacturing sector [Doytch and Uctum, 2019, p. 41] are non-existent.

The following conclusions can be drawn from the literature review:

1) FDI determinants in the service sector vary depending on the type of services;

2) FDI in the service sector is more dynamic than FDI in manufacturing; it is also more sensitive to market size, and labor costs can be considered in this case to be less important than the workforce skill level;

3) FDI in the service sector is often linked to FDI in manufacturing;

4) FDI in the service sector goes hand-in-hand with trade liberalization and they allow trade-related costs to be reduced;

5) FDI in the service sector has a positive impact on TFP, but the scale of the impact is uneven across industries and economies; the strength and occurrence of this effect depends not only on the ability of domestic firms to absorb transferred knowledge, which is a moderating factor, but also on the technological advancement of the service area receiving FDI;

6) through its impact on TFP and economic growth (e.g., by stimulating employment), FDI in the service sector can also translate into the competitiveness of the hoist economy.

The conclusions presented above suggest that the hypothesis proposed in this study, claiming the existence of a link between FDI activity in services and the international competitiveness of the Polish economy in the service sector, is warranted. However, it should be complemented with the recognition of the existence of two types of the link under consideration: direct (FDI $\leftrightarrow$ competitiveness) and indirect (FDI $\leftrightarrow$ mediating variable $\leftrightarrow$ competitiveness). This conclusion is reflected in the empirical part of the study presented.

\subsection{Empirical Linkage of the Competitiveness of the Polish Economy in Services with Foreign Direct Investment. A Comparative Analysis}

Keeping in mind the number of observations being relatively low in terms of the requirements for economic modelling of time series ( $n=10, n=9$ for Slovakia) and panel modelling $(n=36)$, non-parametric correlation coefficients have been used for the analysis (Kendall's tau $-r_{t}$ and Spearman's rho $-r_{s}$; Table 7.1). A statistical significance level $(\alpha)$ of $5 \%$ has been adopted in the study. To structure this part of the considerations (with reference to the literature analyzed), five hypotheses have been 
proposed $\left(\mathrm{H}_{\mathrm{A}}-\mathrm{H}_{\mathrm{E}}\right.$; Figure 7.1), which are related to the main research hypothesis presented at the beginning:

- $\mathrm{H}_{\mathrm{A}}$ : there is a statistically significant correlation between service FDI stock in the host country $i$ and the competitiveness of the service sector in that country: $r\left(I_{-} F D I \_U_{-} i, R C A_{-} U_{-} i\right) \neq 0$;

- $\mathrm{H}_{\mathrm{C}}$ : there is a statistically significant correlation between service FDI stock in the host country $i$ and the GDP value in that country: $r\left(I_{-} F D I_{-} U_{-} i, P K B_{-} i\right) \neq 0$;

- $\mathrm{H}_{\mathrm{E}}$ : there is a statistically significant correlation between service FDI stock in the host country $i$ and the TFP ${ }^{5}$ value in that country: $r\left(I_{-} F D I \_U_{-} i, T F P \_i\right) \neq 0$;

- $\mathrm{H}_{\mathrm{D}}$ : there is a statistically significant correlation between host country's $i$ GDP and the international competitiveness of the service sector in that country: $r\left(P K B \_i\right.$, $\left.R C A_{-} U_{-} i\right) \neq 0$;

- $\mathrm{H}_{\mathrm{E}}$ : there is a statistically significant correlation between host country's $i$ TFP and the international competitiveness of the service sector in that country: $r\left(T F P \_i\right.$, $\left.R C A_{-} U_{-} i\right) \neq 0$;

Figure 7.1. Graphical presentation of auxiliary research hypotheses

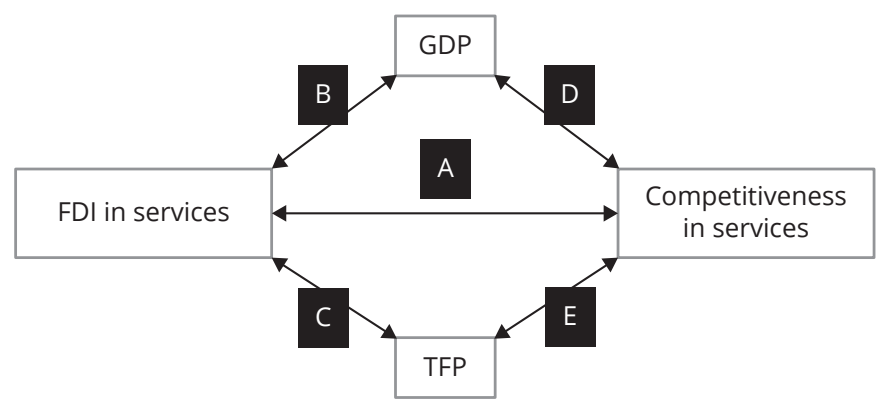

Source: Own study.

In an analysis of the direct link between service FDI stock and RCA $\left(\mathrm{H}_{\mathrm{A}}\right)$, the auxiliary research hypothesis has been confirmed only for Slovakia, for which the estimated coefficient is less than zero (Table 7.1). The second auxiliary research hypothesis $\left(\mathrm{H}_{\mathrm{B}}\right)$, as could be expected from the literature review on the impact of FDI in the service sector and total FDI on the host country's economy, has been confirmed and the estimated coefficients are positive (Table 7.2). The third auxiliary research hypothesis $\left(\mathrm{H}_{\mathrm{C}}\right)$ has been confirmed for Hungary $(r<0)$ and Poland $(r>0)$, with $\alpha=5 \%$, and Slovakia $r>0$ with $\alpha=10 \%$ (Table 7.3). Different results obtained for the individual

5 TFP is defined here as "the portion of output unexplained by the amount of inputs" [Comin, 2010, p. 260], i.e., as the part of economic growth unexplained by measurable factors, or the so-called Solow residual [Fernald, 2014]. 
economies may result (as pointed out by, e.g., by Fernandes and Paunov [2012], but also by other authors whose studies are analyzed in this chapter) from specific areas / types of services, in which FDI was made.

Table 7.1. Results of correlation analysis for $\mathrm{H}_{\mathrm{A}}$

\begin{tabular}{|c|c|c|c|c|c|c|}
\hline $\begin{array}{c}\text { Type of correlation } \\
\text { coefficient }\end{array}$ & $\begin{array}{l}\text { Variables/ } \\
\text { Variables }\end{array}$ & Description & RCA_U_CZ & RCA_U_H & RCA_U_PL & RCA_U_SK \\
\hline \multirow{8}{*}{ Kendall's Tau b } & I_FDI_S_U_CZ & $r_{t}$ & -0.244 & & & \\
\hline & $n=10$ & ist. & 0.325 & & & \\
\hline & I_FDI_S_U_H & $r_{t}$ & & -0.333 & & \\
\hline & $n=10$ & ist. & & 0.18 & & \\
\hline & I_FDI_S_U_PL & $r_{t}$ & & & 0.067 & \\
\hline & $n=10$ & ist. & & & 0.788 & \\
\hline & I_FDI_S_U_SK & $r_{t}$ & & & & 0.778 \\
\hline & $n=9$ & ist. & & & & 0.004 \\
\hline \multirow{8}{*}{ Spearman's rho } & I_FDI_S_U_CZ & $r_{s}$ & 0.297 & & & \\
\hline & $\mathrm{n}=10$ & ist. & 0.405 & & & \\
\hline & I_FDI_S_U_H & $r_{s}$ & & -0.442 & & \\
\hline & $\mathrm{n}=10$ & ist. & & 0.2 & & \\
\hline & I_FDI_S_U_PL & $r_{s}$ & & & 0.079 & \\
\hline & $n=10$ & ist. & & & 0.829 & \\
\hline & I_FDI_S_U_SK & $r_{s}$ & & & & -0.900 \\
\hline & $n=9$ & ist. & & & & 0.001 \\
\hline
\end{tabular}

Source: Own study based on data from UN Comtrade [2019] and OECD [2019b].

Table 7.2. Results of correlation analysis for $\mathrm{H}_{B}$

\begin{tabular}{|c|c|c|c|c|c|c|}
\hline $\begin{array}{c}\text { Type of correlation } \\
\text { coefficient }\end{array}$ & $\begin{array}{c}\text { Variables/ } \\
\text { Variables }\end{array}$ & Description & PKB_CZ & PKB_H & PKB_PL & PKB_SK \\
\hline \multirow{5}{*}{ Kendall's Tau b } & I_FDI_S_U_CZ & $r_{t}$ & .644 & & & \\
\cline { 2 - 7 } & $\mathrm{n}=10$ & ist. & .009 & & & \\
\cline { 2 - 7 } & I_FDI_S_U_H & $r_{t}$ & & .511 & & \\
\cline { 2 - 7 } & $\mathrm{n}=10$ & ist. & & .040 & & \\
\cline { 2 - 7 } & I_FDI_S_U_PL & $r_{t}$ & & & .689 & \\
\cline { 2 - 7 } & $\mathbf{n}=10$ & ist. & & & .006 & \\
\cline { 2 - 7 } & I_FDI_S_U_SK & $r_{t}$ & & & & .002 \\
\cline { 2 - 7 } & $\mathrm{n}=9$ & ist. & & & & .002 \\
\hline
\end{tabular}


cont. tab 7.2

\begin{tabular}{|c|c|c|c|c|c|c|}
\hline $\begin{array}{c}\text { Type of correlation } \\
\text { coefficient }\end{array}$ & $\begin{array}{l}\text { Variables/ } \\
\text { Variables }\end{array}$ & Description & PKB_CZ & PKB_H & PKB_PL & PKB_SK \\
\hline \multirow{8}{*}{ Spearman's rho } & I_FDI_S_U_CZ & $r_{s}$ & .794 & & & \\
\hline & $n=10$ & ist. & .006 & & & \\
\hline & I_FDI_S_U_H & $r_{s}$ & & .673 & & \\
\hline & $n=10$ & ist. & & .033 & & \\
\hline & I_FDI_S_U_PL & $r_{s}$ & & & .782 & \\
\hline & $n=10$ & ist. & & & .008 & \\
\hline & I_FDI_S_U_SK & $r_{s}$ & & & & .917 \\
\hline & $n=9$ & ist. & & & & .001 \\
\hline
\end{tabular}

Source: Own study based on data from the World Bank FRED [2019c] and OECD [2019b].

Correlations of the international competitiveness in services with GDP $\left(\mathrm{H}_{\mathrm{D}}\right)$ exist only in the case of Slovakia $(r<0)$ - Table 7.4, whereas for the RCA-TFP pair none of the calculated coefficients is statistically different from zero $\left(\mathrm{H}_{\mathrm{E}}\right.$; Table 7.5). As regards $\mathrm{H}_{\mathrm{E}}$, it should be noted that with $\alpha=10 \%$, the results for Slovakia are ambiguous.

Table 7.3. Results of correlation analysis for $\mathrm{H}_{\mathrm{c}}$

\begin{tabular}{|c|c|c|c|c|c|c|}
\hline $\begin{array}{c}\text { Type of correlation } \\
\text { coefficient }\end{array}$ & $\begin{array}{l}\text { Variables/ } \\
\text { Variables }\end{array}$ & Description & TFP_CZ & TFP_H & TFP_PL & TFP_SK \\
\hline \multirow{8}{*}{ Kendall's Tau b } & I_FDI_S_U_CZ & $r_{t}$ & 0.067 & & & \\
\hline & $\mathrm{n}=10$ & ist. & .788 & & & \\
\hline & I_FDI_S_U_H & $r_{t}$ & & -.778 & & \\
\hline & $n=10$ & ist. & & .002 & & \\
\hline & I_FDI_S_U_PL & $r_{t}$ & & & .867 & \\
\hline & $n=10$ & ist. & & & .000 & \\
\hline & I_FDI_S_U_SK & $r_{t}$ & & & & .500 \\
\hline & $n=9$ & ist. & & & & .061 \\
\hline \multirow{8}{*}{ Spearman's rho } & I_FDI_S_U_CZ & $r_{s}$ & .079 & & & \\
\hline & $\mathrm{n}=10$ & ist. & .829 & & & \\
\hline & I_FDI_S_U_H & $r_{s}$ & & -.903 & & \\
\hline & $n=10$ & ist. & & .000 & & \\
\hline & I_FDI_S_U_PL & $r_{s}$ & & & .952 & \\
\hline & $n=10$ & ist. & & & .000 & \\
\hline & I_FDI_S_U_SK & $r_{s}$ & & & & .683 \\
\hline & $n=9$ & ist. & & & & .042 \\
\hline
\end{tabular}

Source: Own study based on data from FRED [2019] and OECD [2019b]. 
Table 7.4. Results of correlation analysis for $H_{D}$

\begin{tabular}{|c|c|c|c|c|c|c|}
\hline $\begin{array}{c}\text { Type of correlation } \\
\text { coefficient }\end{array}$ & $\begin{array}{l}\text { Variables/ } \\
\text { Variables }\end{array}$ & Description & PKB_CZ & PKB_H & PKB_PL & PKB_SK \\
\hline \multirow{8}{*}{ Kendall's Tau b } & RCA_U_CZ & $r_{t}$ & (0.067) & & & \\
\hline & $n=10$ & ist. & .788 & & & \\
\hline & RCA_U_H & $r_{t}$ & & -.289 & & \\
\hline & $\mathrm{n}=10$ & ist. & & .245 & & \\
\hline & RCA_U_PL & $r_{t}$ & & & .289 & \\
\hline & $n=10$ & ist. & & & .245 & \\
\hline & RCA_U_SK & $r_{t}$ & & & & -.689 \\
\hline & $n=10$ & ist. & & & & .006 \\
\hline \multirow{8}{*}{ Spearman's rho } & RCA_U_CZ & $r_{s}$ & -.103 & & & \\
\hline & $n=10$ & ist. & .777 & & & \\
\hline & RCA_U_H & $r_{s}$ & & -.358 & & \\
\hline & $n=10$ & ist. & & .310 & & \\
\hline & RCA_U_PL & $r_{s}$ & & & .273 & \\
\hline & $n=10$ & ist. & & & .446 & \\
\hline & RCA_U_SK & $r_{s}$ & & & & -.794 \\
\hline & $\mathrm{n}=10$ & ist. & & & & .006 \\
\hline
\end{tabular}

Source: Own study based on data from UN Comtrade [2019] and the World Bank [2019c].

Table 7.5. Results of correlation analysis for $\mathrm{H}_{\mathrm{E}}$

\begin{tabular}{|c|c|c|c|c|c|c|}
\hline $\begin{array}{c}\text { Type of correlation } \\
\text { coefficient }\end{array}$ & $\begin{array}{l}\text { Variables/ } \\
\text { Variables }\end{array}$ & Description & TFP_CZ & TFP_H & TFP_PL & TFP_SK \\
\hline \multirow{8}{*}{ Kendall's Tau b } & RCA_U_CZ & $r_{t}$ & 0.067 & & & \\
\hline & $\mathrm{n}=10$ & ist. & .788 & & & \\
\hline & RCA_U_H & $r_{t}$ & & .200 & & \\
\hline & $n=10$ & ist. & & .421 & & \\
\hline & RCA_U_PL & $r_{t}$ & & & .200 & \\
\hline & $n=10$ & ist. & & & .421 & \\
\hline & RCA_U_SK & $r_{t}$ & & & & -.378 \\
\hline & $\mathrm{n}=10$ & ist. & & & & .128 \\
\hline \multirow{8}{*}{ Spearman's rho } & RCA_U_CZ & $r_{s}$ & .055 & & & \\
\hline & $n=10$ & ist. & .881 & & & \\
\hline & RCA_U_H & $r_{s}$ & & .358 & & \\
\hline & $\mathrm{n}=10$ & ist. & & .310 & & \\
\hline & RCA_U_PL & $r_{s}$ & & & .285 & \\
\hline & $n=10$ & ist. & & & .425 & \\
\hline & RCA_U_SK & $r_{s}$ & & & & -.552 \\
\hline & $\mathrm{n}=10$ & ist. & & & & .098 \\
\hline
\end{tabular}

Source: Own study based on data from UN Comtrade [2019] and FRED [2019]. 
For Poland (Figure 7.2, panel 2a) the correlation analysis has not confirmed the existence of a direct or indirect (with GDP or TFP as mediating variables) link between FDI in the service sector located in Poland and competitiveness of the Polish service sectors. In other words, the hypothesis put forward in this study has not been confirmed. The conclusions relating to the five auxiliary research hypotheses proposed are the same for Hungary (Figure 7.2, panel 2c).

Figure 7.2. Graphical presentation of the results of an analysis of correlation of auxiliary research hypotheses

2a) Poland

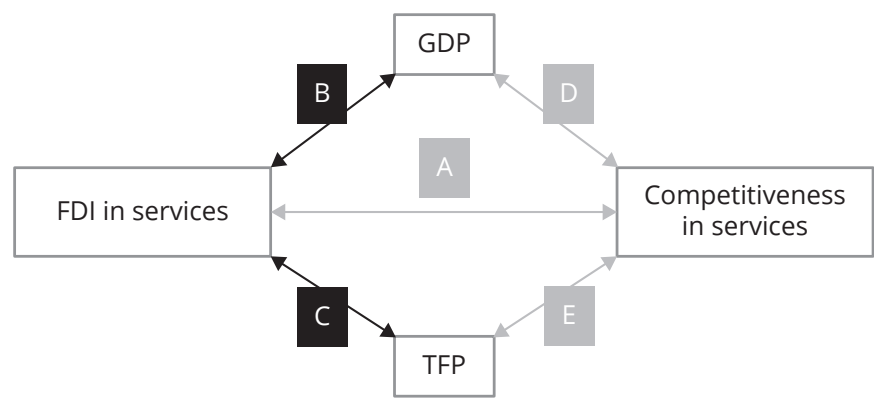

2b) Czech Republic

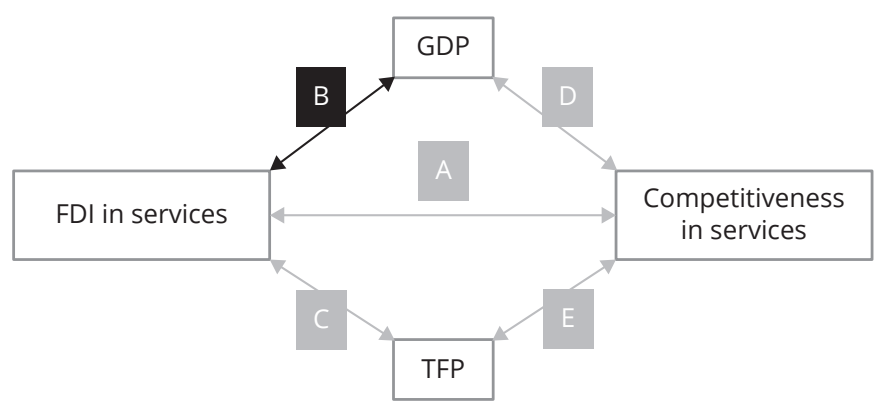

2c) Hungary

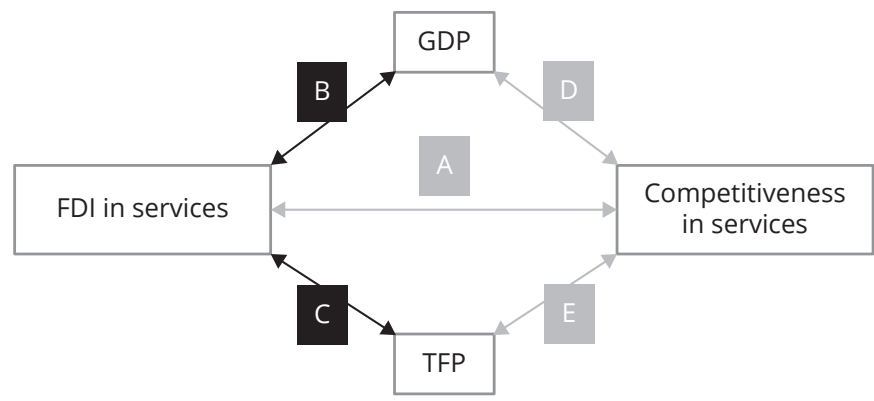


2d) Slovakia

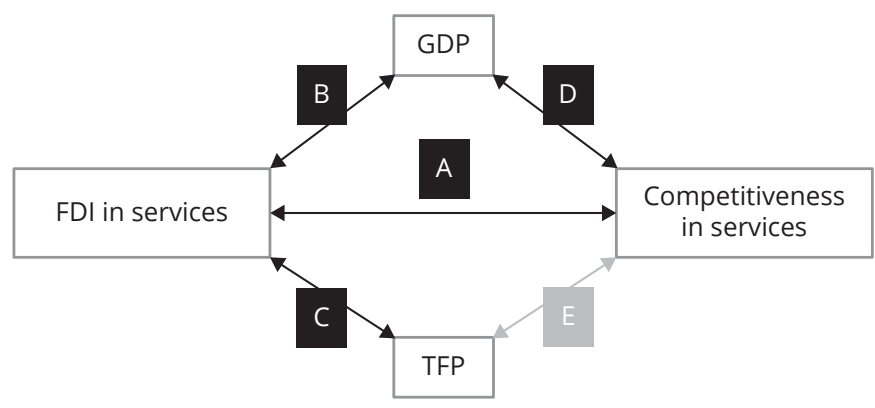

Confirmed hypothesis/relation

Unconfirmed hypothesis/relation

Source: Own study based on data from the World Bank [2019c], OECD [2019b], UN Comtrade [2019] and FRED [2019].

Slovakia (Figure 7.2, panel 2d), is an interesting case, for which a direct link has been found (with GDP as mediating variable) between FDI in the service sector and RCA in services.

Table 7.6. Summary of conclusions on the auxiliary research hypotheses proposed

\begin{tabular}{|l|c|c|c|c|}
\hline \multicolumn{1}{|c|}{ Auxiliary hypothesis } & Czech Republic & Hungary & Poland & Slovakia \\
\hline$H_{A}$ & no & no & no & yes \\
\hline$H_{B}$ & yes & yes & yes & yes \\
\hline$H_{C}$ & no & yes & yes & yes* \\
\hline$H_{D}$ & no & no & no & yes \\
\hline$H_{E}$ & no & no & no & no \\
\hline
\end{tabular}

* For $\alpha=10 \%$.

Source: Own study based on data from the World Bank [2019c], OECD [2019b], UN Comtrade [2019] and FRED [2019].

\subsection{Conclusions}

A research hypothesis presented in this study suggested that there is a link between FDI activity in services and the international competitiveness of the Polish economy in the service sector. To verify this assumption, a review of the literature describing the determinants of FDI in the service sector and the impact of FDI in the service sector on the host economy was carried out. The analysis of FDI determinants provided a basis for a study on FDI in the service sector and its impact on the economy of the host country (indicating, e.g., the two-way relationship between FDI in the service sector and GDP) and a comparison of data on Poland vis-à-vis other economies of the 
Visegrad Group allowed the results obtained to be relativized. Given the limited volume of data, the study used non-parametric correlation coefficients.

An analysis of the literature showed the existence of differences between FDI in the service sector and FDI in the manufacturing sector relating to factors that allow these phenomena to be described. This concerns both, different determinants and their diversity due to their impact time span (short-term vs. long-term impact). The literature analysis also showed that FDI in the service sector has a positive impact on the host economy, e.g., by stimulating TFP, knowledge, employment, and GDP itself. On the basis of these observations, five auxiliary research hypotheses were formulated, taking into account both, direct and indirect (with GDP and TFP as mediating variables) link between FDI in the service sector and the competitiveness of services.

While the analysis of the literature has warranted the main research hypothesis posed in this study, the empirical analysis performed has not confirmed it. The conclusion for Poland is the same in this respect as for the Czech Republic and Hungary. Slovakia is a different case, for which both, a direct and indirect (with GDP as mediating variable) link was identified between FDI in the service sector and the competitiveness of this sector. The divergence of conclusions observed in the study between the economies analyzed is not a new phenomenon. Differences in results may be due, e.g., to differences in the level of technological development [Armenise, Giovannetti and Santoni, 2015], different FDI characteristics [Fernandes and Paunov, 2012] and specializations in different areas of the service sector [Sass, Gál and Juhász, 2018]. Another factor that may influence the results obtained is the choice of the nature of the TFP, or, more precisely, the heterogeneity of its various elements (such as technology, organizational knowledge, and other data, not taken into account as explanatory variables in the equation of economic growth used in estimating TFP values) in the economies studied.

One limitation of the study, resulting from the availability of data, is the quantitative method used, which is of a cognitive rather than determining nature. Its possible future expansion - if longer time series are acquired or a decision is made to extend the panel, while maintaining the requirement of its internal homogeneity - is the use of a more advanced econometric modelling method. Estimating the parameter values of model $R C A_{i t}=\beta_{0}+\beta_{a} X_{a, i t}+\beta_{F D I_{-} U} F D I_{-} U_{i t}+\varepsilon_{i t}{ }^{6}$, where $X_{a, i t}$ represents set $a$ of variables affecting $R C A_{i t}$ other than FDI in the service sector $\left(F D I U_{i t}\right)$ for country $i$ over time $t$, would allow inferences to be made, relating to the existence of a causal link.

6 In the interests of clarity, the equation omits cross-sectional and temporal effects which traditionally need to be taken into account in panel modeling. 


\section{Bibliography}

Armenise, M., Giovannetti, G., Santoni, G. [2015], Do FDI in business services affect firms' TFP? Evidence from Italian provinces, in: Geographical labor market imbalances. Recent explanations and cures, Ch. Mussida, F. Pastore (eds.), Springer, Berlin-Heidelberg, pp. 195-217.

Balassa, B. [1965], Trade liberalization and Revealed Comparative Advantage, "The Manchester School", No. 2, pp. 99-123.

Comin, D. [2006], Total Factor Productivity, in: Economic Growth, S.N. Durlauf, L.E. Blume (eds.), Palgrave Macmillan, London, pp. 260-263.

Doych, N., Uctum, M. [2019], Spillovers from foreign direct investment in services: Evidence at sub-sectoral level for the Asia-Pacific, "Journal of Asian Economics", Vol. 60, pp. 33-44.

Fernald, J. [2014], A Quarterly, Utilization-Adjusted Series on Total Factor Productivity, Federal Reserve Bank of San Francisco Working Paper, No. 2012-19.

Fernandes, A.M., Paunov, C. [2012], Foreign direct investment in services and manufacturing productivity: Evidence for Chile, "Journal of Development Economics", No. 2, pp. 305-321.

FRED [2019], Total Factor Productivity, https://fred.stlouisfed.org/search/?nasw=0\&st=total\% 20 factor\%20productivity $\& \mathrm{t}=$ productivity $\% 3$ Bslovakia $\& \mathrm{rt}=$ slovakia\&ob $=\mathrm{sr} \& \mathrm{od}=\mathrm{desc}$ (26.09.2019).

Ishikawa, J., Morita, H., Mukunoki, H. [2010], FDI in post-production services and product market competition, "Journal of International Economics", Vol. 82, pp. 73-84.

Javorcik, B.S. [2015], Does FDI bring good jobs to host countries?, "World Bank Research Observer", No. 1, pp. 74-94.

Jones, J., Wren, C. [2016], Does Service FDI Locate Differently to Manufacturing FDI? A Regional Analysis for Great Britain, "Regional Studies", No. 12, pp. 1980-1994.

Kolstad, I., Villanger, E. (2008), Determinants of foreign direct investment in services, "European Journal of Political Economy", No. 2, pp. 518-533.

Lo, D., Hong, F., Li, G. [2016], Assessing the role of inward Foreign Direct Investment in Chinese economic development, 1990-2007: Towards a synthesis of alternative views, "Structural Changes and Economic Dynamics", Vol. 37, pp. 107-120.

Misala, J. [2009], Międzynarodowa konkurencyjność gospodarki narodowej, PWE, Warsaw.

Napiórkowski, T.M. [2017], The role offoreign direct investment in economic growth. The production function perspective, "OPTIMUM. Studia Ekonomiczne", Vol. 5(89), pp. 221-236.

Napiórkowski, T.M. [2017b], The impact of Foreign Direct Investment on Poland's economic competitiveness, in: Poland Competitiveness Report 2017. Internationalization and Poland's Competitive Position, M.A. Weresa (ed.), SGH Publishing House, Warsaw, pp. 81-97.

NBP [2019], Cykliczne materiaty analityczne NBP Inwestycje bezpośrednie - zagraniczne, https:// www.nbp.pl/home.aspx?f=/publikacje/zib/zib.html (17.09.2019).

OECD [2019a], FDI flows by industry, https://stats.oecd.org/index.aspx? DatasetCode=FDI_ FLOW_INDUSTRY (13.09.2019). 
OECD [2019b], FDI positions by industry, https://stats.oecd.org/index.aspx? DatasetCode=FDI_ position_INDUSTRY (13.09.2019).

Pilarska, Cz. [2007], Rola bezpośrednich inwestycji zagranicznych $w$ podnoszeniu konkurencyjności polskiej gospodarki, "Zeszyty Naukowe Akademii Ekonomicznej w Krakowie”, No. 738, pp. 5-27.

Ramasamy, B., Yeung, M. [2010], The determinants of Foreign Direct Investment in services, "The World Economy", No. 4, pp. 573-596.

Riedl, A. [2010], Location factors of FDI and the growing services economy. Evidence for transition countries, "Economics of Transition", No. 4, pp. 741-761.

Sass, M., Gál, Z., Juhász, B. [2018], The impact of FDI on host countries: the analysis of selected service industries in the Visegrad countries, "Post-Communist Economies", No. 5, pp. 652-674.

Svedin, D., Stage, J. [2016], Impacts of Foreign Direct Investment on efficiency in Swedish manufacturing, "Springer Plus", Vol. 5(1), s. 614.

UN Comtrade [2019], UN Comtrade Database, https://comtrade.un.org/data/ (18.09.2019).

UNCTAD [2018], Trade in services and employment, United Nations Conference on Trade and Development, New York-Geneva.

UNCTAD [2019], Revealed comparative advantage, https://unctadstat.unctad.org/EN/RcaRadar. html (18.09.2019).

Wang, C.C., Wu, A. [2016], Geographical FDI Knowledge spillover and innovation of indigenous firms in China, "International Business Review", No. 4, pp. 895-906.

World Bank (2019c), GDP (current US\$), https://data.worldbank.org/indicator/ny.gdp.mktp. cd (26.09.2019).

World Bank [2019a], Consumer price index $(2010=100)$, https://data.worldbank.org/indicator/ FP.CPI.TOTL (17.09.2019).

World Bank [2019b], Population, total, https://data.worldbank.org/indicator/sp.pop.totl (17.09.2019).

Yean, T.H., Kam, A.J.Y., Noh, N. [2018], The determinants of inward FDI in selected services industries in Malaysia, "Prague Economic Papers" 2018, No. 2, pp. 215-231.

Zhang, K.H. [2015], What drives export competitiveness? the role of FDI in Chinese manufacturing, "Contemporary Economic Policy", No. 3, pp. 499-512. 
Part III

\author{
Key Factors of Competitiveness \\ of the Polish Economy in 2010-2019 \\ in the Context of the Challenges for the \\ Development of the Service Sector
}



Chapter 8

\title{
Polish Economic Policy in the Context of the Development of the Service Sector
}

\author{
Adam Czerniak, Ryszard Rapacki
}

\subsection{Introduction}

The purpose of this chapter is to assess the main directions of economic policy since the Law and Justice (PiS) government came to power, with a particular focus on actions determining the development of the service sector. The chapter also presents the most important challenges with regard to economic policy four years into the rule of PiS. In this context, we also indicate the potential effects of actions taken in other, non-economic areas of government policy, especially in the field of legal order, which in our opinion had a very strong impact on the conditions for business and investment activities in Poland.

\subsection{Directions of Macroeconomic Policy}

Having won the election in October 2015, the new ruling establishment found itself in a very comfortable position in terms of freedom in pursuing its economic policy. The 2016 Budget Act, for the first time in six years, did not have to be consulted with Brussels, and the government could raise expenditure while reducing taxes, as well as introduce other measures to make fiscal policy more expansive without the risk of being punished by EU institutions under the excessive deficit procedure. What is more, by auctioning off the LTE frequencies to mobile phone operators, the state earned a one-time windfall of PLN $9.2 \mathrm{bn}$, and due to changes in the prices of reserve assets, the National Bank of Poland (NBP) contributed to the budget PLN 7.9 and $8.7 \mathrm{bn}$ from the profit generated in 2016 and 2017, respectively [Council of Ministers, 2016a; 2017b]. Combined with historically low debt service costs, this temporarily opened up ample space to loosen fiscal policy in Poland. 
Having regard to the above, as early as December 2015, the new parliament adopted amendments to the Budget Act and announced the introduction of one of the most expensive social programs in Poland's history, namely the "Family 500+" child support benefit program. Under the act, which entered into force on 1 April 2016, the government started paying parents a monthly benefit of PLN 500 for the second and each subsequent child, and, for those with a monthly income below PLN 800 per family member, also for their first child. The program benefitted parents of 3.8 million children [Council of Ministers, 2017a] at a monthly cost to the government of PLN $1.9 \mathrm{bn}$. In addition, the government spends nearly PLN 350 m each year on operating costs of the benefit payment system. Overall, the cost of the program amounted to PLN $17.6 \mathrm{bn}$ in 2016 and PLN 23.8 bn in 2017, i.e. 1.2\% of GDP (or $6.2 \%$ of budget expenditure and $3.1 \%$ of general government expenditure) [Council of Ministers, 2017c]. In 2018, the amount was slightly reduced as the program was tightened through more rigorous verification of benefit applications. As a result, the number of children covered by the program dropped to $3.6 \mathrm{~m}$, and program costs decreased to PLN $22.8 \mathrm{bn}$ [Council of Ministers, 2019a]. Child support benefits represent the sixth largest item in the budget, and the cost of the program exceeds expenditure on higher education, research and development, unemployment benefits, road investments, or justice.

As announced by the government, the program was to stimulate the fertility rate, which was, at least partially, to increase the future workforce and, thus, the potential rate of economic growth. The Ministry of Family, Labor and Social Policy (MRPiPS) assumes that thanks to benefit payments, the most optimistic scenario of the 2014 GUS forecast will materialize, that is, the fertility rate in Poland will increase to 1.60 in 2025, against 1.30 in the worst-case scenario, and 1.38 in the most likely mid-case scenario. Despite promising initial data on fertility rate growth from 1.29 in 2015 to 1.36 in 2016 and 1.45 in 2017, its further improvement became unlikely, and the program itself did not have a lasting effect on fertility rate growth in Poland. In 2018, the fertility rate returned to a downward trend and reached 1.43 [Council of Ministers, 2019a].

In the medium term, however, the impact of the "Family 500+" program on labor supply will be negative, as it will discourage people, especially second earners, with lower wages from taking up or continuing employment. After the first year of the program, the number of economically active women aged 25-49 was lower by 65,000 than in the scenario excluding the "Family $500+$ " program, with better educated women being those who left the labor market in the first place. This effect was offset slightly in 2018 owing to the GDP growth rate, the highest since the 2008 global financial crisis, and growth in wages, which reduced the number of economically inactive women to approx. 30-40,000 fewer than in the counterfactual scenario without the benefits paid. Thus, if the government scenario materializes, the impact of the "Family 500+" program on 
the demography and the labor market will strike a balance after more or less 30 years. Only then will a sufficient number of young people, born thanks to the program, start working to offset the decline in the economic activity of their mothers. If the program runs until 2050, an additional 2.5 million Poles will be born [Myck, 2016; Arak, 2016].

The second most important economic policy change implemented by PiS was the reversal of the 2012 pension reform by restoring, as of October 2017, the retirement age to 60 for women and 65 for men. The move increased pension expenditure, reduced social security contributions and lowered tax revenue. Based on the government's calculations, it can be estimated that in the first full year with the new law in force, the general government deficit was more than PLN 9 bn higher than in the scenario of a further gradual rise of the retirement age [Council of Ministers, 2016b]. An additional effect of lowering the retirement age was a decline in the economic activity of people aged over 50. In Q4 2017 alone, 313,000 people retired [PAP, 2018], and an additional several tens of thousands did so at the beginning of 2018. According to the results of the Labor Force Survey (LFS), this translated into a significant decrease in the economic activity of women aged 60-64, from $23.8 \%$ at the end of the Q3 2017 to $20.8 \%$ at the end of Q1 2018, and of men aged 65-69, from $18.8 \%$ to $14.6 \%$ at the same time. Consequently, the total economic activity rate for population aged over 50 dropped then from $34.8 \%$ to $33.3 \%$, while in the autumn-winter season a year earlier it remained stable.

With the changes described above taken into account, in 2025 there will be almost 900,000 economically active people fewer than in 2016, and in 2050 - as many as 1.6 million fewer, which means a decrease of the labor force by 11\% [GRAPE, 2016]. This has a twofold impact on the investment activity in the economy. Firstly, a great number of people leaving the labor market in the face of growing personnel deficits in enterprises will reduce their propensity to invest. In mid-2018, as many as $16.4 \%$ of firms had to abandon or limit their investment plans due to personnel shortages [Work Service, 2018], and the percentage has been growing steadily. A lower investment propensity of firms affects the innovativeness of the economy, especially in the industries in which shortages are the most acute, that is, in construction and ICT services. Secondly, in the wake of retirement age reduction workers with the longest work record leave the labor market. This also reduces the ability of enterprises to improve productivity by deploying innovative solutions. Therefore, although as many as three-quarters of enterprises experience difficulties with recruiting new employees, only $17.9 \%$ of investment plans involve mainly the modernization of production technology, including its automation [NBP, 2019].

Apart from the above-mentioned measures, PiS has also made a number of other smaller-scale changes to fiscal policy. One of the most important ones is the 
introduction of a zero-tax threshold. Since 2017, individuals with a taxable income up to PLN 6,600 annually are exempt from personal income tax (PIT), while people with income exceeding the second tax threshold (PLN 85,500) are entitled to a lower tax credit than before the change. In 2018, the zero-tax threshold was raised further to PLN 8,000. The changes increased the general government deficit by PLN 1 bn in 2018, and are estimated to increase it by a further several hundred million zlotys in the following years. In addition to the change in the tax-free amount, the government decided to partially unfreeze wages in the public sector, increase salaries for uniformed personnel, resident doctors and paramedics, and teachers.

The total costs of all reforms launched by PiS within the general government exceeded PLN 35 bn in 2018. Despite such an increase in discretionary public spending, the general government deficit was decreasing steadily over the 2015-2018 period from $2.7 \%$ of GDP in 2015 to the historical low of $0.4 \%$ of GDP in 2018. The improvement of the general government balance was attributable mainly to three factors - a faster-than-potential economic growth in Poland, the tightening of the tax system, especially in taxes on goods and services, and the introduction of two new taxes.

The main source of the GG revenue growth, therefore, was the increase in the tax collection rate, in particular for indirect taxes. To this end, the PiS government continued the policy of fighting tax fraud and aggressive tax optimization, initiated towards the end of the PO-PSL rule. Among the measures implemented, the obligation was introduced for enterprises to prepare the uniform control file, which was expanded in January 2018; in addition, the road transport monitoring system was launched, reverse VAT on some goods was established, as was the so-called fuel package, and from the latter half of 2019 the monitoring system of financial transactions of firms (STIR) was launched, as well as the obligation - for certain transactions - to use the split-payment mechanism under which VAT payments are held in a special escrow account. According to estimates by the finance ministry and the CASE foundation, the VAT gap, i.e., the percentage of expected value added tax revenues which are not collected by the government, decreased from $24.2 \%$ in 2015 to $12.5 \%$ in 2018, resulting in an overall increase of PLN $21.1 \mathrm{bn}$ in VAT revenue. That said, it is worth noting that a significant slowdown in the growth of revenue from direct taxes to a mere $2.7 \% \mathrm{y} / \mathrm{y}$ in 2019 [Ministry of Finance, 2020], indicates that the tax tightening may have been, at least in part, of a procyclical nature, and a further reduction in the VAT gap is unlikely.

With a view to financing increased public expenditure, with effect from February 2016, the government introduced a tax on certain financial institutions (known as "bank asset tax"). It covered banks operating in Poland, insurance companies, savings and credit unions (SKOK), and loan companies, whose assets exceed PLN 2 bn and are 
not subject to a recovery program. Each of those organizations pays annually $0.44 \%$ of the value of its assets less equity and the value of purchased treasury bonds. In 2016, the budget received a total of PLN 3.5 bn - much less than planned in the Budget Act (PLN 5.5 bn). In 2017, due to a longer taxable period and an increase in asset prices, the related revenue increased to PLN 4.3 bn, and in 2018, due to the development of the financial sector, it grew to PLN 4.5 bn [Council of Ministers, 2019c]. In addition to the tax on certain financial institutions, in September 2016 PiS also introduced a turnover tax on retailers, but in response to the European Commission's objection the Ministry of Finance had to suspend its implementation until the end of the first term of the PiS government.

A steep decline of the general government deficit in 2015-2018 encouraged PiS to use the fiscal space in the course of the election campaign. The so-called "Kaczyński Five" was announced, a set of measures designed to support the country's social and economic development. It comprised increasing social transfers, including the expansion of the " $500+$ " program to include the first child from mid-2019 (at the cost of PLN 9.6 bn in 2019 and approx. PLN 20 bn in each successive year), disbursement of an additional pension benefit of PLN 1,100 (PLN 7.6 bn in 2019), introduction of additional benefits for parents with at least four children (PLN 0.8 bn in 2019) and increasing transfers for the support of disabled persons (PLN 0.5 bn in 2019), as well as planned public spending on the expansion of the coach transport network and reduction of the tax wedge by abolishing PIT for persons under 26 years of age, decreasing the lowest PIT rate from $18 \%$ to $17 \%$, and doubling tax-deductible expenses, which will result in a total depletion of tax revenue by more than PLN 10 bn from 2020 [Council of Ministers, 2019b]. The effects of all the above changes in fiscal policy are not to be seen until 2020, when they will start to drive the general government deficit.

In the analyzed period, the PiS government's economic policy focused mainly on increasing social transfers and changes to the tax system, and in the context of supporting economic development - on improving the innovation performance of the economy and its reindustrialization, which we wrote about in the previous edition of the Report [Czerniak and Rapacki, 2019]. Most of the above measures had no effect on the development of the service sector in Poland, and some of them could even produce unfavorable outcomes related to additional red-tape burdens in contacts with fiscal administration, or reduction of workforce supply. What also had an adverse effect on the development of the service sector in Poland was a very fast increase in the minimum wage (from PLN 1850 gross in 2016 to PLN 2600 gross in 2020) and the introduction of the minimum hourly wage from 2017, which applied to employees hired under civil law contracts, widely used in service industries, especially among firms dealing with real estate management and administration. Such regulatory changes contributed 
to a significant increase in the business running costs of service undertakings, forcing redundancies, business automation and/or consolidation for higher profitability.

Analyzing lesser changes to the economic policy during the first term of the PiS government, a number of measures can be identified which had a positive impact on the development of the service sector. They include: 1) abolishing, from January 2017, income tax on intellectual property contributed in-kind to a company, (2) launching the IP Box, a regulatory arrangement under which income derived by an enterprise from intellectual property rights acquired in the course of R\&D activities or R\&D services, purchased from other entities but patented by the enterprise concerned will be taxed at a preferential rate of 5\%,3) reduction, from 2019, of CIT for firms with an annual revenue of less than EUR 1.2 m (approx. 430,000 entities) from $15 \%$ to 9\%, 4) reduction of social security contributions for self-employed with revenue not greater than 2.5 times the minimum wage. However, the above changes were all aimed either at investment in R\&D or at ensuring better business conditions for the smallest businesses, irrespective of the industry in which they operate. Yet the economic policy of PiS lacked measures focused solely on the development of the service sector.

\subsection{Key Challenges}

This section overviews the major challenges facing economic policy in Poland. They include two categories of development threats. The first consists of well-known threats, the ones that have been building up for many years, including those arising from omissions and errors committed by previous Polish governments. The second category comprises new challenges that are a direct consequence of the first four years of PiS being in power.

Our overview encompasses two interconnected perspectives. The first one includes conceptual, political and institutional factors that form a broadly understood framework of business operations and determine the structure and strength of incentives impacting the behavior and decisions of economic actors. The second perspective highlights those development challenges that are associated with functioning of the economy, its growth factors, and macroeconomic performance.

\section{Conceptual, Political and Institutional Challenges}

The first of the fundamental weaknesses of the Polish economic policy is the lack of vision of the target model of capitalism that best suits the conditions and development aspirations of the country. The goal of systemic transformation in Poland - both 
at its onset and all along the way - used to be defined in highly abstract terms as creating a liberal market economy (capitalism), without prejudging its specific design.

Among other outcomes, this caused the institutional architecture (model of capitalism) established in Poland to largely bear the characteristics of a "patchwork" construction. Its individual parts which have been transplanted from different institutional orders, are internally incoherent, and show a low level of complementarity. As a consequence, instead of triggering positive synergies and improved operational efficiency, this institutional ambiguity generates rising frictions, increased idle capacity of the entire system, and progressing entropy [Rapacki and Gardawski, 2019].

Second, until now Poland's current and future role in the European Union has not been clearly defined - other than being mainly a beneficiary of the EU funds. The necessity of meaningful and effective use of the EU funds (and institutions) is beyond discussion. Directions and ways of using EU funds should be, however, a function of the development strategy adopted (an outline of which, four years into the rule of PiS, can only be guessed at). Poland has fairly mastered the art of acquiring EU funds, but it has performed much worse when it comes to defining development priorities in using them, as well as producing a full balance sheet of costs and benefits of the various EU programs, in terms of its own national interest.

In this context, the third development challenge should be perceived, in the form of the risk of perpetuating the peripheral position of Poland in the EU. In such a case, Poland would be mainly a producer of simple manufactured goods, embodying a relatively low value added and low-tech content, and a subcontractor of more technologically advanced products in global networks of transnational corporations. Referring to an influential research current in institutional economics known as "comparative capitalism", Poland would then represent a classical example of the "dependent market economy" [Nölke and Vliegenthart, 2009], or an "FDI based, second-rank market economy" [Myant and Drahokoupil, 2011] model of capitalism.

Fourth, the government failure to create conditions fostering long-term economic development should be considered as one of the greatest challenges, including ensuring positive externalities for the private sector. This mainly concerns the underfunding of the R\&D sector, the lack of support in creating and improving the quality of human capital, miscomprehension of the meaning of one of the biggest barriers to the development of the Polish economy, i.e., a low level of social capital and insufficient support for the advancement of information and communication technologies.

Fifth, this weakness results, among others, from a strong redistributive bias in public spending policy at the expense of development expenditures, failure to accomplish the so-called "golden rule" of public finances, a growing scale of rent seeking, and persistence of the unproductive entrepreneurship pattern [cf. Baumol, 1990]. 
What is more, sixth, the symptoms of Myrdalian soft state in Poland persist - the incidence of unreported economy is still too big and compliance with the law is too weak, which means, among other things, a strong asymmetry between formal and informal institutions, to the advantage of the latter [Rapacki (ed.) et al., 2019]. At the same time, there are more and more manifestations of insufficient quantity and decreasing quality of public goods and merit goods supplied by the state (such as healthcare and education).

Finally, seventh, unlike several other transition countries in the region (Slovakia, the Baltic states), Poland failed to substantially downsize its government and to reduce the scope of its functions over the past 10 years. If the proportion of public expenditure to GDP is adopted as the basic gauge of the size of government, it should be noted that in recent years it has remained, as it did in the early $1990 \mathrm{~s}$, at above $40 \%$. This is an indicator approximately two times higher than in countries with a comparable level of economic development (23-24\%), and close to the EU and OECD average. This means that we carry a lot more of the "state" on our shoulders than we are economically able to bear.

\section{Macroeconomic Challenges}

The most important development challenges of a broadly defined macroeconomic nature facing Polish economic policy include the following phenomena:

1) Unfavorable demographic trends - a significant decline in population (over the next 30-40 years), change in the age structure of society, emigration and brain drain, permanent decline in the dependency ratio showing the number of people in the labor force per retiree.

2) Imperfections of the labor market, manifesting themselves in a participation rate of the population in the labor market below the EU average, high unemployment rate among young people and a large share of flexible forms of employment. In addition, the labor market has seen the so-called negative intertemporal feedbacks gaining in strength in the recent years. On the one hand, in the short term, the labor market is becoming increasingly flexible, which facilitates the absorption of asymmetric shocks. However, on the other hand, this tendency perpetuates, in the long run, the existing foundations of the international competitiveness of Polish economy (low costs, low and medium level of processing of exports, low value added), as it undermines incentives to upgrade qualifications and to innovate [Rapacki, 2016].

3) The lowest propensity to save and the lowest investment-to-GDP rate among the Central and Eastern European countries. In the light of the endogenous model 
of economic growth, it is the investment rate and national savings that finance these investments in the long run, and are a prerequisite for fast and sustainable economic growth.

4) Low innovativeness of the economy that has persisted for years. Its many symptoms include a low contribution, of a mere $8 \%$, of high-tech products in the export of manufactured goods, or a huge deficit in the international trade of licenses (the ratio of expenditure on license imports to revenues from license exports being 10:1).

5) A low (or, as some studies show, even decreasing) stock of social capital in Poland. Given that fact, Poland would fall into the category of low-trust society [Fukuyama, 1997]. Moreover, while the persisting lack of trust among Poles in the state institutions is strongly conditioned by history, a new phenomenon in Poland is the emergence of a symmetrical distrust in the state-citizen and the state-private entrepreneur relations. Its symptoms include red-tape barriers proliferated by the public administration and increasing the bureaucratic interference that may limit the scope of economic freedom already achieved.

6) Another serious development threat that has been emerging increasingly clearly boils down to rapidly growing tensions in the national energy balance, resulting, inter alia, from delayed investment in the development and modernization of the energy base. They are augmented by the prospect of a significant increase in the costs of electricity generation and supply in Poland, stemming from the intergovernmental arrangements in the European Union, adopted in autumn 2014 (climate package), concerning the reduction of harmful emissions and the related need to switch energy production to more environmentally friendly technologies based on renewable energy sources.

\section{New Challenges}

This sub-section indicates the most important challenges to economic policy resulting from actions taken by PiS during its first four years in power. In the context of the parliamentary elections won in 2019, the direction of those actions is most likely to be continued, which means maintaining an expansionary fiscal policy and a loose monetary policy. We also consider it highly probable that the scenario of institutional changes initiated in November 2015 will be continued, aimed at deforming the very basis of the legal order existing so far in Poland, which may lead to further deterioration of Poland's image abroad, weakening its international position and increasing its marginalization in the European Union. The coming true of this scenario will entail the emergence of new challenges in economic policy of a short, medium and long-term nature. 


\section{a) Short-Term Effects}

- Strong fiscal expansion, mainly due to the increase in budget expenditure on large-family benefits (the "Family 500+" program). As we have shown in the first part of the chapter, the total costs for general government of all reforms implemented by PiS exceeded PLN 35 bn in 2018. However, meeting all election promises of the ruling party, in terms of social transfers, may mean an increase in additional burdens to the government budget of up to PLN 50 bn a year.

- Increased budget expenditure (mostly intended for consumption) financed from the growing deficit and public debt will also trigger the mechanism of crowding out private investment from the economy, which will consequently lead to a change in the structure of national income distribution (on the demand side) - the private sector's share will fall in favor of the public sector.

- At the same time, as a result of the increase in rigid budget expenditure, which will not be matched by a parallel, sustainable increase in the sources of their financing, the structural deficit may also increase.

- The persisting general government deficit, indicating an increase in negative government savings, will constrain the capability to finance domestic investment from savings of the private sector (firms and households).

- The shrinking stream of private savings will have a similar effect, which will be part of a very probable scenario in 2020: continuation of the Monetary Policy Council's loose monetary policy stance - a further rise in inflationary expectations and inflationary pressure - negative real interest rate - decrease in marginal propensity to save.

- Increase in the perceived investment risk in Poland (especially, political and institutional), which will translate into a rising cost of borrowing in international financial markets.

- Complete dismantling of the three-pillar pension system by taking over the remaining part of pension assets accumulated in Open Pension Funds, OFE (nationalization of retirement savings). This move was only partially offset by the introduction of Employee Capital Plans in 2019, which, on the one hand, implied the actual abolishment of the second pillar of the system and, on the other hand, produced much smaller effects than expected.

- The lowering of the statutory retirement age (from 65 to 60 for women and from 67 to 65 for men), effective 1 October 2017. This move poses an additional constraint to the current and future liquidity of the Social Insurance Fund and the government budget. According to Santander Bank's estimates (January 2019), the total costs of lowering the retirement age amounted to approx. PLN 7 bn in 2018. 


\section{b) Medium and Long-Term Effects}

\section{Macroeconomic}

- Increased inflationary pressure and expectations. This increase will be a derivative of three interrelated factors:

1) significant loosening of fiscal and monetary policy;

2) almost full utilization of production capacity in the Polish economy (the output gap is estimated at only about $-0.6 \%$ of potential GDP), as well as a significant deceleration of its potential growth rate (up to a maximum of $2.5 \%$ per year).

3) negative supply shocks both external and of the domestic origin (weather anomalies and coronavirus pandemic effects).

- This may mean that additional growth stimuli, generated by fiscal or monetary expansion is likely to result in overheating the Polish economy and, instead of accelerating its growth, lead to accelerated inflation.

- In a slightly longer perspective, the factors likely to slow down the growth of the Polish economy are insufficient propensity to save (currently about 17\% of GDP) and insufficient investment rate (17\% instead of at least $24-25 \%$ of GDP).

- The crowding out effect may have a similar consequence (see above). It will lead to a downward trend in the average efficiency of resource allocation in Poland (decrease in the TFP growth rate) and, thus, a further deceleration of the potential growth rate of the Polish economy.

- In this context, it is also worth pointing to the continuing contradiction between the actual actions of the ruling political party and the major goals of Strategy for Responsible Development announced by the then Deputy Prime Minister Mateusz Morawiecki in mid-February 2016 (providing, inter alia, for a significant rise in the rate of domestic savings and the rate of investment, coupled with increased national innovative capacity and support for domestic capital). However, as is well known from the fundamentals of economic theory, the rate of consumption and the investment rate cannot be increased at the same time, assuming that the role of foreign savings in the economy is to be further limited.

- The Morawiecki Plan also displays an internal contradiction of a deeper institutional nature. While the objectives formulated in the plan (e.g., increasing the ability of the Polish economy to innovate) have been transplanted mainly from the variety of capitalism called the liberal market economy (or the Anglo-Saxon model of capitalism), the means and ways of achieving them (strong statism and the increase in the importance of non-market forms of coordination, renationalization) come 
from a completely distinct institutional order, referred to as a coordinated market economy (or also as the Continental European or Nordic model of capitalism). ${ }^{1}$

- The government's acquisition of the remaining part of the OFE assets will result in, among others, replacing (reallocation in time) the official "visible" part of public debt with hidden or "invisible" debt (promise of future pension payments) and a significant increase in the latter form of debt.

- Lowering the retirement age will reduce the labor supply, drastically lower the replacement rate for future retirees and may at the same time threaten the foundations of the long-term solvency of ZUS and the general government.

- Similarly, this decision could further weaken the Warsaw Stock Exchange, whose performance has already deteriorated significantly as a result of the nationalization of half of the OFE pension assets by the PO-PSL government in 2014.

\section{Institutional}

The first four years of the PiS rule gave also birth to the emergence of new development challenges embedded in the institutional environment. The most important ones include the following:

- demolishing the foundations of the liberal democracy system based on checks and balances and the separation of the executive, legislative and the judiciary powers.

- increasing centralization of power and intensifying attempts to weaken local self-government.

- restricting the freedom of actions of the "third sector", i.e., non-governmental organizations.

- actual dismantling of the civil service;

- limiting the freedom of the media;

- deepening of existing divisions in society, disappearance of the sense of community;

- a further decline in the level of trust and willingness to cooperate in society;

- weakening of incentives for productive entrepreneurship and investment.

1 This insight can be further expanded - the development strategy being actually implemented in Poland may be summarized as a peculiar blend of: 1) neoliberal goals, 2) conservative values, and 3) statist means and tools employed by an authoritarian political power, 4) under deep political divisions and lack of social dialog. 


\subsection{Summary - Key Long-Term Consequences}

In summary, it is worth pointing out that the cumulative impact of the developmental challenges presented above, combined with an insufficient response of economic policy, may lead to a decline in the international competitiveness of the Polish economy. In particular, it is worth highlighting the possibility of the following longterm consequences of this scenario:

1) perpetuation of the imitative and peripheral pattern of development of the Polish economy;

2) augmenting the role of informal institutions at the expense of formal ones;

3) unfolding process of anomie in society;

4) strengthening incentives for unproductive and destructive entrepreneurship;

5) further rise in the idle capacity of the institutional system and the progressive erosion of the comparative institutional advantage of Poland.

All these factors may be conducive to a permanent decline in the potential rate of economic growth. The symptoms of this unfavorable tendency have already appeared in Poland - in the last few years there has been a reduction in the potential growth rate of Polish economy from over $5 \%$ to about $2.5 \%$ i.e., by half. What is more, according to long-term projections of the European Commission, OECD, and our own forecasts [Matkowski, Próchniak, Rapacki, 2016] ${ }^{2}$, this rate may decelerate even further after 2020 - below $2 \%$ per annum.

\section{Bibliography}

Arak, P. [2016], Jak program 500+ wptynie na rynek pracy, Polityka Insight, 22.02.2016.

Baumol, W. [1990], Entrepreneurship: Productive, Unproductive and Destructive, "Journal of Political Economy", Vol. 98(5), pp. 893-921.

Council of Ministers [2016a], Wieloletni plan finansowy państwa na lata 2016-2019, Warsaw. Council of Ministers [2016b], Stanowisko Rady Ministrów wobec prezydenckiego projektu ustawy o zmianie ustawy o emeryturach i rentach z Funduszu Ubezpieczeń Społecznych oraz niektórych innych ustaw, Warsaw.

Council of Ministers [2017a], Wieloletni plan finansowy państwa na lata 2017-2020, Warsaw. Council of Ministers [2017b], Ustawa budżetowa na rok 2018. Uzasadnienie, Warsaw.

2 The latest simulation forecast of the development trajectory of Poland's economy and the income convergence process in relation to the EU-15 countries can be found in Chapter 4 of this Report. 
Council of Ministers [2017c], Sprawozdanie Rady Ministrów z realizacji ustawy o pomocy państwa w wychowywaniu dzieci w latach 2016-2017, Warsaw.

Council of Ministers [2017d], Strategia na rzecz Odpowiedzialnego Rozwoju do roku 2020 (z perspektywa do 2030 r.), Warsaw.

Council of Ministers [2019a], Sprawozdanie Rady Ministrów z realizacji ustawy o pomocy państwa $w$ wychowywaniu dzieci $w 2018$ roku, Warsaw.

Council of Ministers [2019b], Wieloletni plan finansowy państwa na lata 2019-2022, Warsaw.

Council of Ministers [2019c], Sprawozdanie z wykonania budżetu państwa za okres od 1 stycznia do 31 grudnia 2018 r. Omówienie, Warsaw.

Czerniak, A., Rapacki, R. [2019], Directions and Key Challenges of Economic Policy in Poland in the Context of the Fourth Industrial Revolution, in: A.M. Kowalski, M.A. Weresa (eds.), Poland. Competitiveness Report 2019. International Competitiveness in the Context of Development of Industry 4.0, SGH Publishing House, Warsaw, pp. 165-180.

European Commission [2016], Autumn Economic Forecasts, Brussels.

European Commission [2018], Autumn Economic Forecasts, Brussels.

GRAPE [2016], Obniżenie wieku emerytalnego. Jakie będą skutki?, http://grape.org.pl/blog/ co-dokladnie-oznacza-obnizanie-wieku-emerytalnego-w-polsce/ (25.10.2016).

Matkowski, Z., Próchniak, M., Rapacki, R. [2016], Real Income Convergence between Central Eastern and Western Europe: Past, Present, and Prospects, "Ekonomista", No. 6, pp. 853-892.

Ministry of Finance [2020], Szacunkowe dane o wykonaniu budżetu państwa za styczeń - grudzień 2019 r., Warsaw.

Myant, M., Drahokoupil J. [2011], Transition Economies: Political Economy in Russia, Eastern Europe and Central Asia, John Wiley \& Sons, Hoboken-New York.

Myck, M. [2016], Estimating Labour Supply Response to the Introduction of the Family 500+ Programme, CenEA Working Paper Series 01/16.

NBP [2019], Szybki Monitoring NBP. Analiza sytuacji sektora przedsiębiorstw, No. 01/19, Economic Analysis Department, Warsaw.

Nölke, A., Vliegenthart, A. [2009], Enlarging the Varieties of Capitalism: The emergence of dependent market economies in East Central Europe, "World Politics", Vol. 61(4), pp. 670-702.

PAP [2018], ZUS zdecydował o wypłacie emerytur dla 313 tys. osób, 5.01.2018.

Rapacki, R. (ed.), Próchniak, M., Czerniak, A., Gardawski, J., Horbaczewska, B., Karbowski, A., Maszczyk, P., Towalski, R. [2019], Kapitalizm patchworkowy w Polsce i krajach Europy Środkowo-Wschodniej, PWE, Warsaw.

Rapacki, R. [2016], The Institutional Underpinnings of the Prospective Euro Adoption in Poland, in: Y. Kotyama (ed.), The Eurozone Enlargement: Prospect of New EU Member States for Euro Adoption, Nova Science Publishers, New York, pp. 65-86.

Rapacki, R., Gardawski, J. [2019], Istota i najważniejsze cechy kapitalizmu patchworkowego $w$ Polsce i krajach Europy Środkowo-Wschodniej, in: R. Rapacki (ed.), Kapitalizm patchworkowy $w$ Polsce i krajach Europy Środkowo-Wschodniej, PWE, Warsaw, pp. 343-353.

Work Service [2018], Barometr Rynku Pracy X. III kwartał 2018 r., https://www.workservice. com/pl/content/download/6806/50226/file/Raport_Barometr_Rynku_Pracy_X.pdf (25.05.2019). 
Chapter 9

\section{Investments and Financing the Development of the Service Sector in Poland}

Piotr Maszczyk

\subsection{Introduction}

The value and dynamics of changes in investment outlays is one of the key variables determining both the rate of growth and the structure of gross domestic product (GDP) and, consequently, the competitiveness of economies. Thus, investments determine how quickly the economic model in a given country will evolve, which translates into effects including the development of the service sector. Domestic funds were the main source of financing investment in Poland until the end of 2019, and the inflow of foreign capital, while still significant, was steadily decreasing. This chapter provides a presentation of an analysis of the impact of investment outlays on the development of the competitiveness of the Polish economy and the capability to finance the development of the service sector, with a particular focus on changes that took place in 2012-2019, in the context of tendencies witnessed in other EU countries.

\subsection{Analysis of Trends Prevailing in 2012-2019}

When analyzing the rate and direction of change in investment outlays in Poland in 2010-2010, three key factors that determine this component of global demand should be considered. Firstly, the last eight years were marked by a steady decrease in the adverse consequences of the 2008 crisis in the global economy, especially in the economies of most EU countries. By 2017, there were no more signs of the crisis. This means that exogenous factors had a neutral effect on the pace and level of changes in investment outlays in Poland from 2014 onwards, and a definitely positive effect in 2017 and 2018. Secondly, however, a departure from in this favorable trend could be seen in 2019. The increasing uncertainty and growing perception of the impending slowdown in the global economy, and, in particular, the decline in the growth rate of 
the German economy and consequently the EU economy, meant that exogenous factors began to have a moderately adverse impact on the level and dynamics of changes in investment outlays in Poland.

Thirdly, 2016 saw a rather fundamental shift in Polish economic policy, which was related to the change of government following the 2015 elections. A thorough revision of fiscal policy combined with specific rhetoric, used in a more or less skillful manner by politicians from coalition parties centered around PiS, meant that endogenous factors were absolutely crucial in the context of new investments. Of course, this strong negative impact of adaptive expectations of business entities turned out to be much longer-lived than could still be expected in the first half of 2019. While local elections were held in Poland in 2018, a circumstance conducive to public investment spending owing to the nature of the run-up campaign, and the 2019 parliamentary elections also had a positive impact on public actors' investment activity, this finally had no significant effect on a very moderate investment activity of private sector enterprises. When assessing, in particular, investment outlays in the enterprise sector in 2019, it is hard not to admit that their moderately positive dynamics continued to be primarily influenced by variables strongly determined by the continuing uncertainty in relations between the state and the private sector. Thus, the favorable or negative tendencies witnessed in the global economy, as well as all Poland's major trading partners, combined with a quickly deteriorating local investment climate, gradually reduced the significance of the positive factors that had brought about a steady increase in the value of investments after 2016. Especially given that the investment value growth rate was higher both Hungary and in the Czech Republic. This lends relativity to the opinion, which is quite common among politicians and analysts sympathizing with the ruling coalition, that the steady growth in investment in the Polish economy witnessed in the last three years was a derivative of the beneficial impact of the political environment on the decisions of the enterprise sector in this area.

The first two years of the analyzed period (2012-2013) saw a decline in investment value in Poland. During these two years, negative tendencies in the investment structure were related to the spreading adverse consequences of the 2008 global economic crisis, which started in the US and expanded globally in the following years. Therefore, for as long as the negative consequences of the crisis strongly persisted in the global economy, they substantially reduced the impact of beneficial tendencies witnessed in Poland. It was not until its adverse effects in the Polish economy were finally overcome in 2014 that it became possible to stabilize the positive (though no longer increasing) rate of growth of investment outlays in two subsequent years. It should, however, be emphasized that as is the case with of GDP, the negative impact of global economic turbulence on the value of investment outlays in Poland was 
relatively limited compared to the other EU countries. The year-on-year calculation of investment value did not decrease in the analyzed sub-period more than by $1.8 \%$, while in 2007 the amount earmarked for investment increased by as much as 17.6\%.

On the one hand, growing investment outlays undoubtedly stimulated the increase of the competitiveness of the Polish economy. On the other hand, Polish enterprises doing increasingly well in the EU markets boosted investments, and thus their production capacity, in order to meet the growing demand at home and abroad. The path of changes in both GDP and global demand and investments in 2012-2020 continues to positively verify the stylized facts resulting from the design of the demand model. According to its assumptions, investments are the component of global demand, which reacts to changes in the economic situation much more strongly than its other parts, and contributes to these changes itself by creating a specific feedback mechanism. Thus, investments stimulated both the demand and supply sides of the Polish economy. As indicated by the data analyzed further on in this chapter, such a relationship between investments and the rate of economic growth could be confirmed in the economy over the past eight years. Despite a slight acceleration of the economic growth rate, a decrease in the growth rate of gross fixed capital formation in 2015 should be treated as a one-off event, being a specific "correction" of the two-digit dynamics from the previous year. However, it should also be viewed as a positive effect of the balance of foreign trade on the rate of economic growth. The rate of change in domestic demand was nearly 1.5 pp lower in 2015 than in the previous year (3.4\% compared to $4.7 \%$ in 2014), which, according to the assumptions of the Keynesian model, had to result in a lower investment growth rate.

In 2012, uncoincidentally called "the year of the second wave of crisis", a sharp decline in the GDP growth rate (only 1.6\% against previous 5\%) meant, as could be expected, a decrease in investment value by $1.8 \%$. It was therefore reasonable to presume that 2013, which saw a decrease in the GDP growth rate of $0.2 \mathrm{pp}$ against the previous period, would be another year of decline in the value of investment outlays. The expected effect did occur, and the value of investments dropped by $1.1 \%$. The rate of economic growth accelerated by nearly $2 \mathrm{pp}$ in 2014, which, in line with expectations based on the demand model, allowed gross fixed capital formation to be increased by 10\%. The GDP growth rate was even faster in 2015 (3.8\%), and investment outlays increased again, albeit slower than in the previous year $(6.1 \%$, or nearly 4 pp slower). However, the decline in the growth rate dynamics of investment outlays in this case was caused in this case, as already mentioned, by a slower growth rate of domestic demand. In 2016, the economic growth rate decreased by almost 1 pp in relation to the previous period, which - as could be expected from the conclusions arising from the demand model - led to a decrease in the value of investment outlays 
of almost $8 \%$. Identical tendencies continued in 2017. Acceleration of the economic growth rate to $4.8 \%$ (i.e., by more than $2 \mathrm{pp}$ ), made it possible not only to reverse the previous negative tendencies, but also to generate a growth in investment outlays by almost four percent.

Based on 2018 data and preliminary estimates presented by GUS for 2019, it can be stated that the relationship between the rates of change in investment and GDP is fairly stable. A further acceleration of the economic growth rate by almost $5 \mathrm{pp}$ (the GDP growth rate $5.1 \%$ in 2018) was correlated with an increase in gross fixed capital formation by $8.9 \%$. On the other hand, the economic slowdown witnessed in Poland in 2019 (according to preliminary estimates presented by GUS at the end of 2020, the GDP growth rate in Poland stood at 4\%, i.e., it was more than $1 \mathrm{pp}$ lower than in the previous period) almost automatically translated into a decline in the growth rate of the value of investment outlays.

An attempt to estimate investment outlays in 2020 is the subject of considerations presented later in the chapter, but a slowdown of the current, relatively high, rate of economic growth, anticipated by a large majority of economists, is expected to be accompanied by a decline in the growth dynamics of the value of investment outlays. Thus, this means that the mechanism and dependencies observed in 2010-2017 will be maintained (Figure 9.1).

Figure 9.1. Dynamics of changes in investment outlays in Poland during 2010-2019

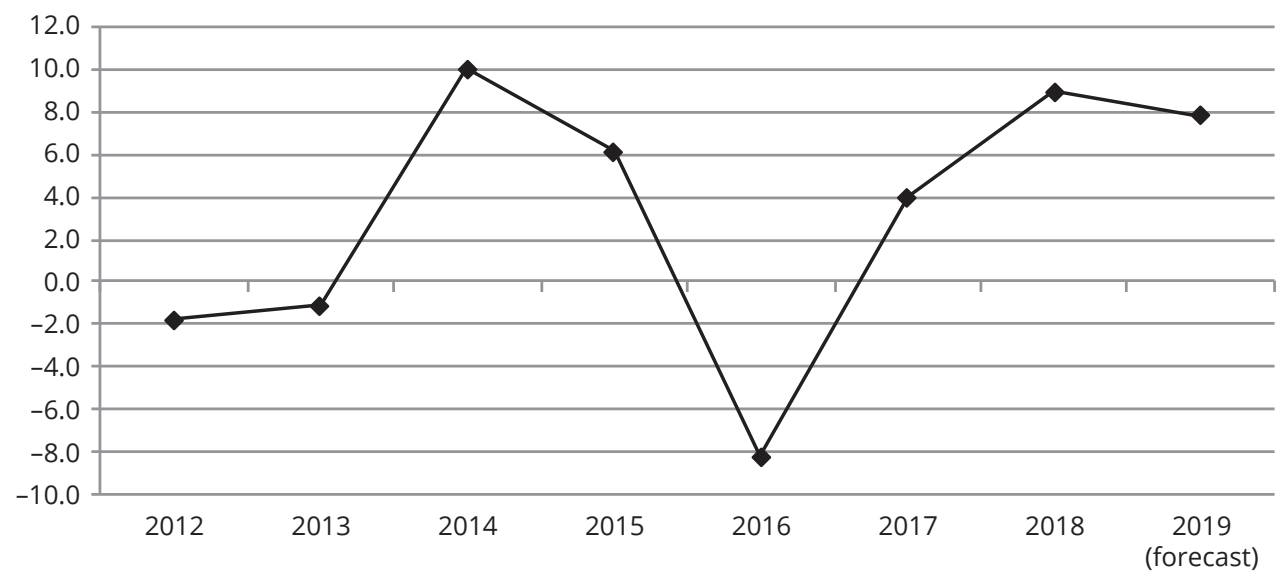

Source: Own calculations based on GUS data (www.stat.gov.pl).

According to preliminary data published by GUS, the value of investment outlays increased in Poland by over 7.8\% in 2019. It should be noted that, on the one hand, this value is consistent with the forecasts under the base scenario included 
in the Competitiveness Report 2019 (it presented a forecast of the growth rate of investment outlays in 2019 of not less than 5\%, with a possible upward deviation of up to $3 \mathrm{pp).} \mathrm{Importantly,} \mathrm{the} \mathrm{forecast} \mathrm{was} \mathrm{devised} \mathrm{with} \mathrm{the} \mathrm{reservation} \mathrm{that} \mathrm{the} \mathrm{GDP}$ growth rate in the same period would range at approx. 4.5\%. Having regard to the fact that the real growth rate of global product in Poland in 2019 was 0.5 pp lower, the data reflecting the change in gross fixed capital formation can be described as moderately positive. Based on the forecasts developed in Q1 2019, it can also be said that both the external and internal situation of Poland was determined by a set of factors that prevented the achievement of a two-digit growth rate of investment. GUS data (February 2020) show total investment outlays of PLN 104.5 bn at the end of the third quarter of 2019, i.e., 15\% higher than at the end of the corresponding period of the prior year. At the same time, according to a preliminary GDP estimate for 2019 released by GUS, it can be expected that the value of investment in 2019 in the entire economy will reach about PLN 291 bn, i.e., which means a 7.8\% increase compared to the previous period (in 2018, the value of investment outlays in the entire economy decreased by 8.9\%). Thus, the investment rate in the national economy (the ratio of gross fixed capital formation to GDP in current prices) in 2019 increased for a second time in a row and reached, according to GUS preliminary estimates, $18.8 \%$, compared to $18.2 \%$ in 2017 and $17.7 \%$ in 2016. It should be stressed, however, that in 2015 the rate still exceeded $20 \%$.

Deceleration of the rate of growth in the value of investment outlays in Poland in 2019 was mainly a consequence of exo- and endogenous factors. Maintaining relatively high dynamics resulted primarily attributable from a growth in public investment related to the political business cycle and parliamentary elections which were held in Q4 2019. Investments implemented by private enterprises decreased markedly, especially in the latter part of the year. The main factor limiting the investment growth dynamics of the private sector in Poland was the policy pursued by the authorities, which involved a persisting high risk of potential changes in the tax system, combined with growing distortions in the operation of fiscal control mechanisms - especially given a very high level of utilization of production factors (around $80 \%$ ) and the record-high value of current assets in bank deposits in the enterprise sector. Having regard to the above considerations, as well as a record-low unemployment rate and negative real interest rates that could be used to "leverage" credit, enterprises should increase investment at a double-digit rate. However, this did not happen, which leads to a negative assessment of the impact of political risk factors on the level and pace of changes in investment outlays in 2019. In this context, entrepreneurs usually pointed to confusion with the trade tax and the protracted (and still unfinished) decision-making process related to changes in the amount of contributions remitted to the Social 
Insurance Institution (ZUS) by workers hired under a contract of employment. Especially in financial and business services, as well as the most innovative industries (IT, computer game production), a possible repeal of the limit of 30 times the average wage could mean a drastic increase in the cost of doing business. Thus, the potential prospects for the development of the service sector in Poland become much less optimistic. However, in the context of declining investment activity of companies, the precarious situation among Poland's main trading partners, particularly Germany, which was on the brink of recession in 2019, cannot be overlooked. While in November 2019 the ECB started implementing the stimulus package for the euro area, but its possible positive effects will probably not materialize until mid-2020.

In the first quarter of 2019, investment growth rate was as high as $12.6 \%$ (the highest since Q1 2015), but even then the growth was selective. Companies with more than 50 employees recorded acceleration in only 9 out of 22 industrial sectors. The combined rapid growth was the result of the activity of several industries - utilities, electrical appliances, administration, land transport, automotive manufacturing, and coke production. Such an industry structure absolutely did not guarantee sustainability of the recovery witnessed. As might be expected, the rate of growth in the value of investments began to decrease steadily in successive quarters (9\% year-on-year in Q2 and only $4.9 \%$ compared to the previous period in Q4) - especially if large projects implemented in the energy sector are deducted from the investment value, i.e. completion of work related to the commissioning of two power units of the Opole Power Plant, as announced by PGE in October (the estimated value is about PLN 11.6 billion). Excluding these projects, the growth rate of investment in Q4 2019 would be less than $3 \% \mathrm{y} / \mathrm{y}$.

The results recorded in the second half of 2019 represent an incentive to revise previous optimistic forecasts made by many economists and analysts, in fact not only those related to the broad-based ruling establishment. In line with their expectations, a fast investment growth over four quarters, i.e. in the second half of 2018 and the first half of 2019, should make it possible to gradually upgrade the machinery fleet of Polish enterprises and increase the degree of its mechanization and robotization, which was supposed to be a way of dealing with supply constraints in the labor market. Unfortunately, definitely less optimistic data for Q4 2019 cause us to revise these expectations. Despite the undoubtedly positive tendencies in investment in 2019, one cannot but notice the earlier period of almost six years of stagnation or even a decline in the value of investment outlays. It is therefore hard to prejudge whether we are faced with a harbinger of a lasting trend, which can mean, in a longer run, the beginning of not only quantitative but also qualitative changes in the Polish economy, or rather an event of a short-term nature. 
The value of the FDI flowing into Poland in 2019 had a moderately positive impact on gross fixed capital formation in the same period. According to estimates presented by the Polish Investment and Trade Agency (PAIH), in 2019 foreign firms decided to locate 56 investment projects in Poland. Yet this result means a significant decrease in the number of launched investment projects compared to the record year 2018, when as many as 71 new projects were implemented. However, as noted by PAIH representatives, investment value of key significance, and it increased last year by more than a third compared to 2018, to almost EUR 3 bn, i.e. approx. PLN 13 bn. This probably means that the existing trends in this area will continue.

According to NBP data, the net inflow of foreign direct investment to Poland amounted to PLN 50.4 bn in 2018, an increase of $45.3 \% \%$ compared to 2017. The value of transactions in respect of Polish direct investment abroad in 2018 was PLN 1.5 bn against PLN 8.2 billion in 2017. The most important component of foreign direct investment in 2018 were reinvested profits, worth PLN 37.8 bn. On the other hand, Poland's foreign direct investment commitments at the end of 2018 amounted to PLN 859.1 bn and were $2.7 \%$ higher\% than at the end of the previous year. The countries from which foreign capital flows into Poland are led by Germany (PLN $172.7 \mathrm{bn}$ ), followed by France (PLN 89.4 bn), which overtook the United States (PLN 88.6 bn) ranked second in 2017. Also Polish investors invest in Poland through special-purpose vehicles located in other countries. This way, in 2018, they maintained the seventh position among the largest direct investors in Poland, and the value of those investments (PLN $34.5 \mathrm{bn}$ ) represented $4.0 \%$ of foreign direct investment commitments.

A vast majority of investors (more than 90\%) surveyed for this question by PAIH consider Poland as a good place for investing. Almost the same percentage declared they would choose Poland if they were to decide again where to invest. According to studies conducted by PAIH, it can be stated that the investment climate in Poland is conducive to attracting foreign businesses, which develop technological innovations and generate new jobs for highly-skilled specialists. Thus, their activities contribute to the development of the service sector in Poland. In this context, it is worth stressing that the sector that stands out most clearly in the PAIH portfolio is that of business services.

Foreign investors declare that challenges related to the recruitment of employees and the increase of labor costs, which might potentially impede the implementation of investment projects in Poland, have been offset by positive factors, e.g. a still good economic situation, which is highly appreciated by the survey participants, and improving performance, which allows unit labor costs to be kept under control. Apart from economic stability, which the respondents believe has been improving, the high attractiveness of the Polish investment offering is also shaped by factors such as the 
size of the internal market, availability of materials and components, and cooperation with local administration. Employees are also Poland's strength. In this case, three elements: labor productivity, organizational culture and loyalty were ranked among the top five by investors. Furthermore, among factors that limit the attractiveness of Poland, the surveyed representatives of foreign entities point to insufficient stability and predictability of law, low efficiency of the commercial judiciary and not so much the rates of taxes themselves as the formalities related to them.

What had a definitely positive impact on the growth rate and level of investment outlays in Poland in 2019 was a growing absorption rate of structural funds flowing into Poland from the EU budget. While the situation in this area is obviously far from satisfactory, the utilization rate of EU aid funds significantly improved in 2018 and 2019. Delays in the implementation of funds under most operational programs, which ranged around 12 months in Q1 2017, or more than 20 months for railway projects, were reduced significantly at the end of previous year, although the targets assumed under earlier plans had yet to be achieved. Local government enterprises, which were particularly affected by the slowdown, started to gradually increase the number of contracts put out to tender, mainly in construction, as the local government election campaign was gaining momentum

Unfortunately, upon the end of the previous financial perspective, the Ministry of Development ceased the regular publication of data on the value of eligible expenses of beneficiaries, resulting from submitted payment applications. Based on partial data available at the beginning of March $^{1}$, it can, however, be estimated that at the end of December 2019 beneficiaries managed to generate 272,700 payment applications (a growth of more than $58 \%$ from a corresponding figure at the end of the previous year), for the co-financing amount representing EU funds of PLN 116 bn (a growth of almost 49\%). This represents $37.4 \%$ of allocation under the 2014-2020 financial perspective, a rate almost 12 pp higher than the corresponding value at the end of 2018. The allocation utilization rate ranged around $26 \%$ at the time (in amount in the Polish national envelope within the European Social Fund and the European Regional Development Fund amounted to about PLN 310 bn) ${ }^{2}$.

The utilization rate of these funds appears to be still extremely small, given that payments under the current financial perspective can only be made until the end of 2022. Corresponding indicators at the end of 2017 were nevertheless more than 22 pp lower (compared with the December 2019 value). The number of payment applications generated by the beneficiaries was lower by more than 200,000 (only 62,800

\footnotetext{
1 See Ministry of Development Funds and Regional Policy, European Funds Portal, www.funduszeeuropejskie.gov.pl (4.03.2020).

2 Using an artificial conversion rate of 4 PLN/EUR.
} 
agreements were signed), with PLN 33.8 bn in co-financing from the EU funds. Thus, over the past two years, the amount of payment applications attributable to EU funds increased by as much as PLN 82.2 bn. In order to lend additional strength to this moderately optimistic picture, it is worth noting that the total value of beneficiaries' eligible expenditure, resulting from the payment applications submitted, reached the following respective amounts at the end of the settlement period under the previous financial perspective: PLN 52.5 bn in 2015 (compared to PLN 64.2 bn in 2014), with the EU co-financing of PLN 37.8 bn (PLN 45.4 bn in 2014).

A comparison of the rate of change in investment outlays in 2012-2019 in Poland, the Czech Republic, Slovakia and Hungary, countries that have traditionally been our main competitors in the absorption of investment in the region, clearly shows that although the level and dynamics of accumulation in all Central and Eastern European countries which joined the EU in 2004 are primarily under the influence of exogenous factors (global crisis, EU membership, economic situation in Germany), they differ quite significantly. ${ }^{3}$ More precisely, a progressive convergence of trend and dynamics of investment outlays can be seen in Poland, the Czech Republic and Slovakia, while a relatively uniform pattern for this group begins to increasingly differ from the mechanisms taking shape in Hungary.

During the analyzed period, the value of investment in the Czech Republic was seen to increase in 2014-2015, and again in the 2017-2019 period. Thus, the direction of changes continuing in the country in the value of investment outlays fell in line with the trend observed in Poland over the eight years relevant to this study. The amplitude of fluctuations in the value of investment in the Czech Republic and Poland was also similar. With the value of investment increasing, the growth rate in each of these countries reached double-digit values only once (in 2014 in Poland, and in 2018 in the Czech Republic), whereas, with investment value falling, the growth rate did not exceed $5 \%$. The year 2016 was an exception from this rule, when the value of gross fixed capital formation decreased by almost 8\%. In addition, the Czech Republic not only failed to achieve a stable upward trend in this component of demand, spanning four years, as was the case in Poland, but it was also unable to return to the level of investment recorded before the 2008 crisis.

Slovakia is the country where the pace and dynamics of investment outlays reflected, until recently, a change pattern which was the most similar to that observed in Poland. In the analyzed period, just as in the case of the Czech Republic, the direction

3 Investment outlays in the Czech Republic and Hungary in 2011-2018 was determined on the basis of Eurostat data published on the website: http://epp.eurostat.ec.eu.int (4.03.2020). Annual data come from quarterly statements. Values for Slovakia have been estimated based on information provided by IMF: ww.imf.org (4.03.2020). 
of investment changes was consistent with the trend observed in Poland as many as eight times. The amplitude of fluctuations in the value of investment in Slovakia was nevertheless much higher than that maintained in Poland and the Czech Republic, both with regard for the years in which investment outlays grew, and when this component of global demand was seen to decrease.

In 2019, Hungary (like Poland, Slovakia and the Czech Republic) not only managed, for the third time in a row, to achieve a positive growth rate of investment outlays, but it also boasted an impressive double-digit growth figure (13.4\%, while in 2018 a corresponding growth rate was $19.8 \%$, and in $2017-21.5 \%)$. Such a significant difference in this component of the global demand growth rate additionally aggravates the divergent trend characterizing the specificities of investment projects located in Hungary in relation to Poland, the Czech Republic and Slovakia. That said, it should also be kept in mind that this impressive growth rate followed an equally dynamic decline in investment outlays in 2016 (by 16\%). On the other hand, the value of investment in Hungary increased not only in 2014 and 2015 (as in other countries of the Visegrad Group), but also in 2013. The impressive investment growth rate in 2017-2019 clearly shows that the negative impact of the public finance crisis on the investment level faced by the Hungarian economy until recently has actually run out, even though the increase in this component of global demand in 2015 was symbolic (by 1.9\%), followed by a steep decrease in 2016 .

A comparison of the total investment growth dynamics in Poland and in the other new EU member states in 2010-2019 is presented in Figure 9.2.

Figure 9.2. Comparison of investment growth in Poland, the Czech Republic, Slovakia and Hungary in 2010-2019

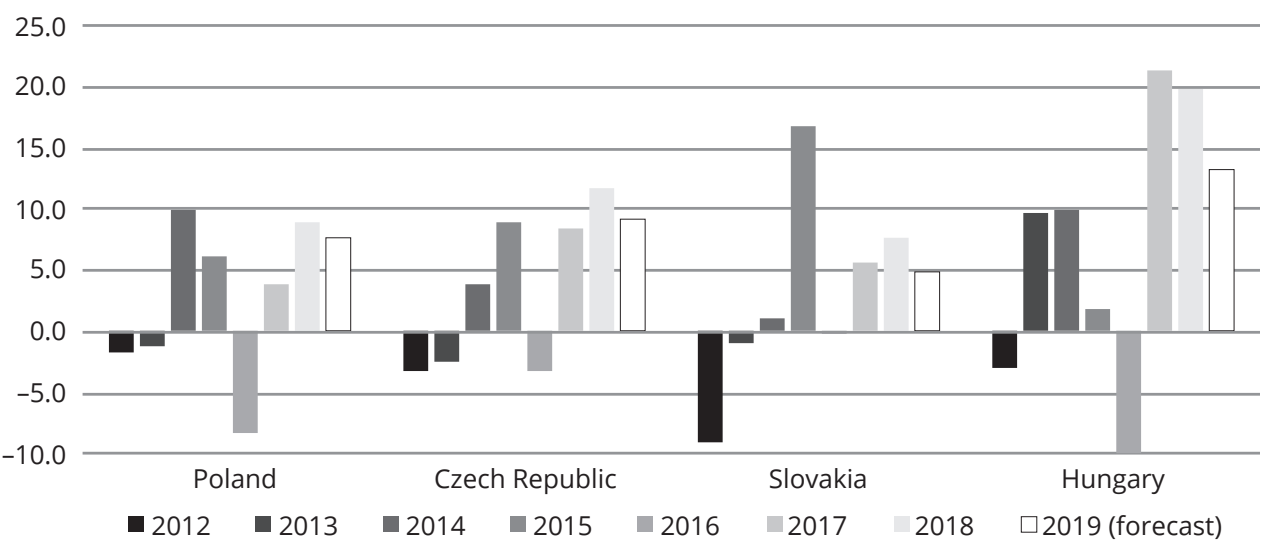

Source: Own calculations based on Eurostat (http://epp.eurostat.ec.eu.int) and IMF (ww.imf.org) data. 


\subsection{Investment Dynamics - a Forecast Attempt}

Given the set of variables described above, which contributed to a slowdown in the investment value growth rate in 2019, forecasting the direction of this component of global demand in 2020, as was the case last year, seems to be a relatively easy task carrying little risk. This is especially the case as the majority of analytical institutions expect that the positive growth rate of the value of investment outlays will continue, whereas the investment growth rate will slightly slow down.

Trends observable on the supply side of the Polish economy, mainly in capital productivity, have been the subject of analysis in previous editions of the Competitiveness Report many times. To recapitulate these considerations, it can be reminded that the hypothesis on the correlation of a high growth rate of investment outlays with equally high dynamics of the GDP growth rate has been subject to explicitly positive empirical verification for many years in Poland. When a downward tendency in fixed capital formation appears (as was the case, e.g., in 1997-2003), a decrease in the GDP growth rate can almost automatically be observed. The same tendency can be seen in the context of the GDP index when there is a reversal of the downward tendency of the capital expenditure growth rate (2004-2008 as well as 2017). A specific "business cycle" can even be said to exist in this context, in which the periods of rapid growth in capital expenditure and decline in productivity intertwine with years in which capital and labor inputs decrease, while the TFP value grows, which causes the GDP growth rate to remain at a positive level.

In this context, the data published by GUS [2020], as well as an analysis of quarterly changes in GDP, global demand and its most important components, combined with economic situation surveys, suggest that Poland will see a further slowdown in economic growth in 2020 , most likely by $1 \mathrm{pp}$. (with fluctuation band of $+/-0.5 \mathrm{pp}$ ) compared to the value achieved in 2019. It is worth recalling here that the assumptions of the budget law take into account the rate of GDP growth of 3.7\%, which is lower than the growth rate achieved in 2019 by only $0.3 \mathrm{pp}$. With household consumption growth slowing down, a higher rate of GDP growth can hardly be expected. It is worrying that, despite the government's reform package (extension of the "Family 500+" program to include every first child, doubling the tax-deductible expenses for taxpayers filing the PIT tax return form, income tax exemption for persons under 26 years of age, and lowering the second tax bracket from 18 to 17\%) in Q3 and Q4 2019, the increase in household consumer spending slowed down significantly. Their value increased by 3.3\% compared to the corresponding period of the previous year (in Q3 it was 3.9\%). This growth rate was the lowest since Q2 2016. Investment or net exports can also 
hardly be expected to take over as the main demand factor for growth, especially if EU countries fail to significantly slow down or stop the spread of the coronavirus and the state close to a global pandemic will persist not only in Q1 but also in Q2 2020. The decline of interest in mass events and tourist trips may, admittedly, be partly offset by larger purchases of disinfectants and food with extended shelf life, but an increase in COVID-19 cases will significantly increase the degree of uncertainty in the economy and thus naturally reduce the scale of investment activities.

Given the projected economic growth rate of $3 \%$ (with an acceptable fluctuation band of $+/-0.5 \mathrm{pp}$ ), all of these signs suggest that a growth rate of investment in Poland in 2019 will be not less than 3\%, with the possibility of this value being exceeded by as much as $2 \mathrm{pp}$, especially as sentiment among business operators has also been deteriorating. According to data published by NBP in December 2019, a decline in profitability is expected next year by almost $20 \%$ of business owners, which means an increase of nearly $7 \mathrm{pp}$ compared with Q3 of the previous year. The assessment of the economic situation also deteriorated by almost $4 \mathrm{pp}$. There are growing concerns about the situation in the euro area, mainly in Germany. Service enterprises can be affected particularly badly, which are additionally struggling with growing business costs and an unstable legal environment. This may mean a lack of new investment or even stopping projects already in progress, which will certainly slow down the development of the service sector (mainly business and IT services) in Poland.

On the other hand, however, given the stable stance of the Monetary Policy Council (MPC), which rules out, in principle, an interest rate hike in the first and probably in the second half of $2020^{4}$, as well as a further boost of absorption of EU funds, translating into an increase in the number and scale of investments in the public sector, this year will see a continuation of the existing favorable trends in financing investment outlays. The financial situation of Polish businesses is good, the financing conditions are favorable, and the capacity utilization in the economy remains high, and therefore investment is necessary to meet the still growing (albeit increasingly slower) demand.

The forecasts presented above are based on the assumption that the European and global economy will be developing in line with a relatively conservative base scenario, under which no additional (compared to the situation in Q1 of the year) unexpected factors, whether positive or negative, will emerge in 2020. Economic or political

4 At the beginning of March 2020, a decline in petroleum prices could be seen as one of few favorable effects of the SARS-CoV-2 spread, which will probably have a positive effect on the inflation rate in Poland and result in its decrease in the latter part of the year. One could also ponder whether concern about the global economic slowdown triggered by the COVID-19 pandemic will not translate into a reduction of interest rates in the USA, the EU, and other globally leading economies, which will mean maintaining the existing trends in Poland. The first sign of such changes can be the reduction of interest rates in the USA on 3 March 2020. 
disruptions in the USA (presidential elections are due to take place in the country in 2020) and a sharp slowdown in the growth rate of the Chinese economy, which is likely to see a negative rate of growth in Q1 and possibly Q2 of this year, would have a definitely adverse impact on the volume of investment outlays in the Polish economy. In such a situation, a global recession (the scale of which is currently hard to predict) would probably be unavoidable, which would not only affect the rate of economic growth in Poland but also lead to a rise in global risk aversion and weakening of the zloty. Also, a possible spread of the COVID-19 epidemic from China to Europe and the rest of the world would certainly lead to a recession in Poland in 2020, which of course would mean a steep decline in the value of investment. In such a situation, the MPC would probably accelerate the change in monetary policy attitude from neutral to expansionary, but even a deep reduction in interest rates would probably not be enough to reverse negative trends.

On the other hand, an improved economic situation (or at least a lower-than-expected negative rate of GDP growth) and quick curbing of the global coronavirus pandemic would mean a positive impact of exogenous factors on the GDP and investment growth rate in Poland. However, in the first quarter of 2020, it is hard to assess the probability of either the positive or the negative scenario.

\section{Bibliography}

Eurostat [2020], www.ec.europa.eu/eurostat/ (4.03.2020).

GUS [2020], "Biuletyn Statystyczny", No. 1/2020.

IMF [2020], ww.imf.org (4.03.2020).

Ministry of Development Funds and Regional Policy [2020], European Funds Portal, www.

funduszeeuropejskie.gov.pl (4.03.2020).

NBP [2019], www.nbp.pl (4.03.2020).

PAIH [2020], www.paiz.gov.pl (4.03.2020). 

Chapter 10

\section{Labor Market Challenges in the Context of Employment Shifts in the Service and Industrial Sectors}

Anna Maria Dzienis

\subsection{Introduction}

Research on skill change and shifts in employment distribution has been growing over the past two decades trying to find out what are the reasons behind the growth in employment of high-skilled workers and the decline in the proportion of middle-skilled jobs (Acemoglu, 2002; Autor, Levy and Murnane, 2003; Acemoglu and Autor, 2011). These studies are mostly focused on developed economies, with some of them indicating such aspects of the phenomenon under study as upskilling, deskilling and job polarization, while others point to the technological exposure and job routinization (Autor, Levy and Murnane, 2003). There are also voices that the structural change and the increase in the share of jobs in the service sector are responsible for the evolution of the employment structure (Cirillo, 2018).

This paper provides an analysis of the employment structure dynamics in the service and industry sectors in Poland through economic and socio-professional categories. Moreover, to determine the key factors behind the employment changes in sectors, occupations and regions, the standard shift-share analysis is performed. This approach allows a detailed insight to be gained into the employment shifts by decomposing employment growth into the region's potential, industrial structure, regional (or occupational) competitiveness components. Employing this method will help to identify the most competitive occupations and regions for the future growth of service and industry sectors in Poland. 


\subsection{Literature Review}

Changes in technology are assumed to be skill biased (Skill-Biased Technical Change -SBTC), since new technology generates higher demand for or complements highly skilled workers (Acemoglu, 2002; Acemoglu and Autor, 2011). Empirical research by, e.g., Goos and Manning (2007), however, suggests that the employment polarization is better explained by the routinization hypothesis than the skill-biased technical change. Routine-Biased Technological Change (RBTC), widely described by Autor, Levy and Murnane (2003), presumes that workers performing routine jobs are being replaced by technology and that this labor-capital substitution affects middle-skilled workers. As a result, Autor, Levy and Murnane (2003) introduce a classification of tasks in two dimensions, routine vs. non-routine, and manual vs. cognitive, which leads them to the conclusion that nonroutine tasks requiring flexibility, creativity, problem-solving and complex communications capabilities are being supported by computer technology. According to the authors, technology-driven shifts in task content produce changes in labor demand favoring educated workers (Autor, Levy and Murnane, 2003). This phenomenon has recently become a broadly discussed research topic resulting in various empirical studies on developed economies in the United States, United Kingdom and Europe.

Another seminal work by Acemoglu and Autor (2011), "Skills, Tasks and Technologies: Implications for Employment and Earnings", stresses that a richer groundwork for studying current changes in employment distribution is needed, triggered by, e.g., development of technologies and interactions among worker skills. The authors concentrate on routinization of job tasks in the United States, setting a new framework for an endogenous allocation of skills to tasks and a richer interaction between technology and wages (Acemoglu and Autor 2011, p. 1047). For their part, Michaels, Natraj and Van Rennin (2014) follow the task-based theory and using cross-industry data for eleven developed countries (the US, Japan and nine Western European countries) test if the ICT improvements increase demand for the most educated and reduce demand for the middle educated workers. They find out that in the countries in question skill upgrading could be observed in services (e.g. finance, information and communication, business sector) and manufacturing (Michaels, Natraj and Van Rennin, 2014).

Bárány and Siegel (2018) argue that job polarization is a long-run phenomenon that was already present in the $1950 \mathrm{~s}$ in the US and that it is closely linked to the shift from manufacturing to services. The authors present another explanation to polarization, attributing it to structural change. They claim that understanding the sectoral labor market trend is important for studying the occupational trends and prove 
a particular connection between structural change and occupational structure in the US (Bárány and Siegel, 2018). This stance is supported by earlier works such as Kupets (2014), a rare example of research on developing economies tackling this topic. In this case, the key factors of occupational shifts in Ukraine are found rather in deindustrialization, growth in retail trade and other less knowledge intensive services. Additionally, the author touches upon the problem of education-job mismatch related to the sharply increasing number of high-skilled labor and low capability of absorption of these workers by the economy in transition (Kupets, 2014). The skill-biased technical change paradigm is also questioned by Cirillo (2018) who analyzes job polarization trends in Europe and finds out that the phenomenon emerges mainly in the service sector, which is also linked to part-time and low-quality employment (Cirillo, 2018).

Recently observed changes in the dynamics of employment and the distribution of occupations in the US, UK or Europe have pushed researchers to test the existing theories such as SBTC, develop new ones (e.g., RBTC), and search for other reasons lying behind the growing number of highly educated workers and the shrinking group of medium-skilled labor. Besides the impact of factors such as technology and routinization of tasks, empirical studies bring explanations that involve structural change, development of service sector, legal form of employment contract, labor market institutions and policies.

\subsection{Recent Trends in Poland's Employment and Occupational Distribution}

During the last decade, Poland has experienced significant positive developments in the labor market. The registered unemployment rate decreased from 9.4\% in 2008 to $5.8 \%$ in 2018, and the employment rate of persons aged 15-64 by LFS grew respectively from $59.2 \%$ to $67.4 \%$. Interestingly, the rate for older persons (55-64 years old) improved by 17.3 pp and reached the value of 48.9\% in 2018 (GUS, 2019).

In 2018, Poland occupied $6^{\text {th }}$ position among the EU member states regarding the share of employment with upper secondary and post-secondary non-tertiary education (levels 3-4 according to the International Standard Classification of Education - ISCED11) among the 15-64 year-old population. The rate stood at 60\% (68\% in 2008), just after the Czech Republic (71\% in 2018), Slovakia (70\%), Croatia (63\%), Hungary (62\%) and Romania (62\%), while the EU28 average was then $48 \%$. The percentage of population with tertiary education (levels 5-8) in the group in question reached 35\% in 2018, increasing by 12 pp over the past decade, while those with less than primary, primary and lower secondary education (levels 0-2) did not exceed 5\%, recording 
a decline of 4 pp since 2008 (See: Figure 1). It is worth noting that this share was the $4^{\text {th }}$ from the bottom among the EU28, with the lowest shares reported for Lithuania (3\%), Czech Republic (4\%) and Slovakia (5\%) (Eurostat, 2019).

Figure 10.1. Employment distribution by education (15-64 age group, \%), 2009-2018

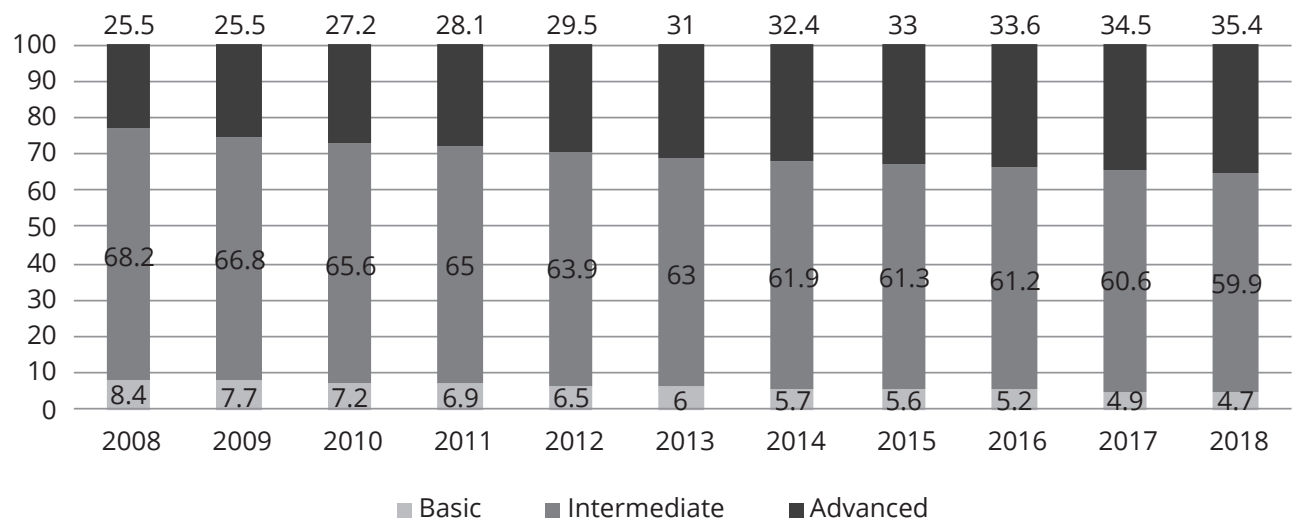

Source: Compiled by author based on data from ILOSTAT: https://ilostat.ilo.org/data/, accessed 15.10.2019.

Figure 10.2. Employment distribution by occupation (five occupation groups according to ISCO-08, ILO) 2008 and 2018, \%

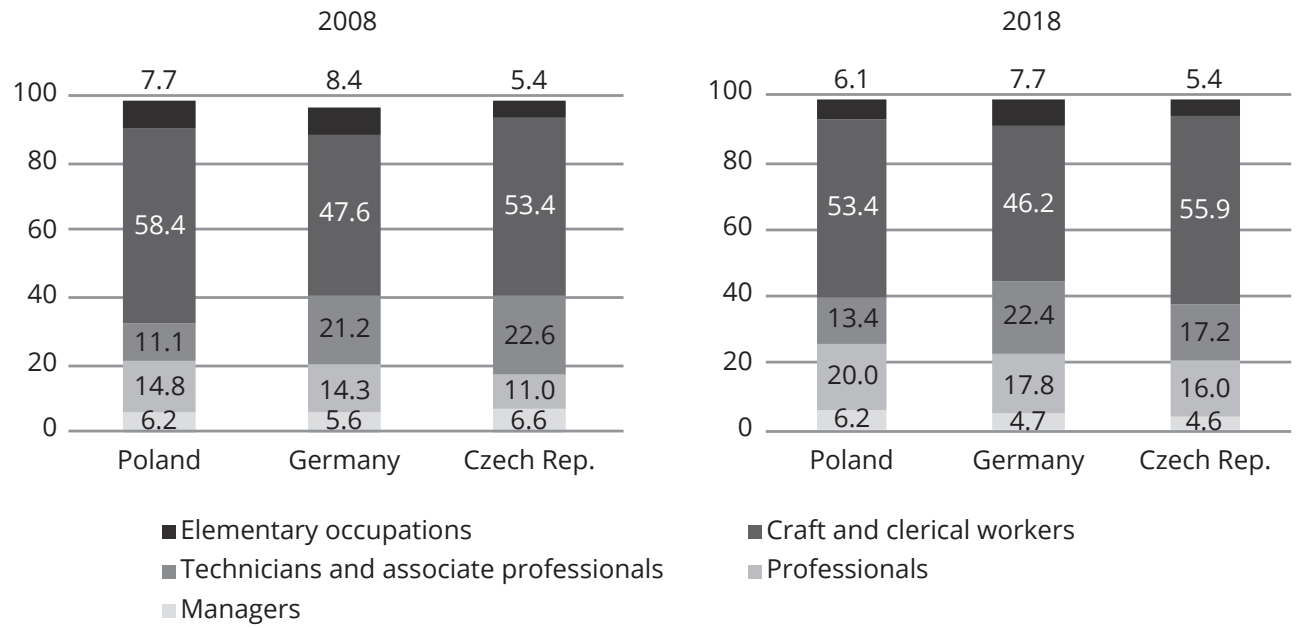

Source: Compiled by author based on data from Eurostat, Employment by occupation and economic activity, from 2008 onwards, NACE Rev. 2, https://ec.europa.eu/eurostat/web/lfs/data/database (22.09.2019).

According to ILO data, among the nine occupation groups, the highest change in employment between 2008 and 2018 was recorded for professionals - 5 pp while the deepest decrease in numbers was seen for elementary occupations $-5.5 \mathrm{pp}$. The 
negative trend can also be observed for clerical support workers, and craft and related trades workers, occupations that account for the middle-skilled labor (ILO, 2019). Figure 10.2 and Figure 10.3 show that similar developments could be seen in Germany while in the Czech Republic craft and clerical workers together with professionals were the groups with the highest gains. This trend is even more pronounced when the service and manufacturing sectors are analyzed separately (Eurostat, 2019).

Figure 10.3. Employment dynamics by occupation* in the service and manufacturing sectors (2008-2018 growth average)

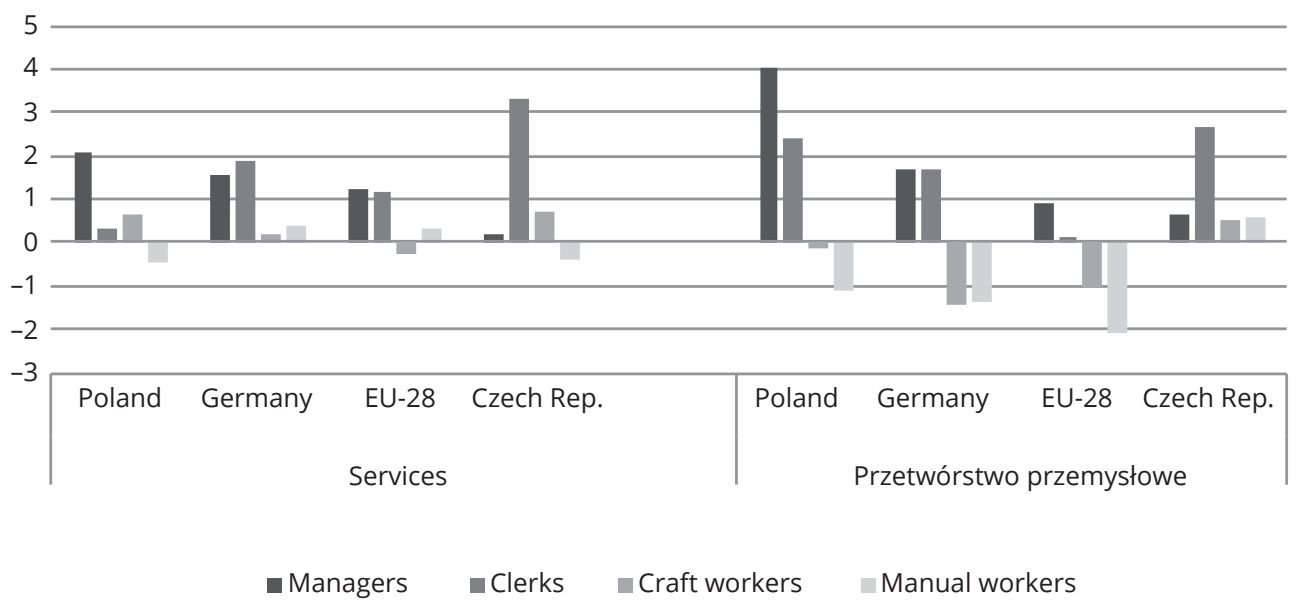

* Managers: managers, professionals and technicians; Clerks: clerical support workers and service and sales workers; Craft workers: skilled agricultural, forestry and fishery workers and craft and related trades workers; Manual workers: plant and machine operators and assemblers, elementary occupations (Cirillo, 2018).

Source: Ibidem

\subsection{Regional Employment Shifts and Sectoral Job Changes}

To find out the sources of changes in labor demand, Berman, Bound and Griliches (1994), Acemoglu and Autor (2011), Goos, Manning and Salomons (2014), Fonesca, Lima and Pereira (2018), Cirillo (2018) and others perform shift-share decomposition. In this section, a conventional shift-share method will be applied to regional and occupational data by sector, which allows for a detailed insight into the changes in employment distribution in all these three dimensions. The employment data for 16 voivodeships by NACE rev. 2 sector and for employment in 8 occupations by NACE Rev. 2 sector for the years 2008 and 2018 is provided by Eurostat. Based on how Eurostat aggregates the data, the results in tables are shown for the industry and service sectors 
for regional shift-share analysis and for the manufacturing and service sectors in the case of occupational shift-share decomposition.

The formula follows the classical shift-share equation (Herzog and Olsen, 1977), where $d$ is the change over the time period divided into the following effects: national growth, $g$, industry mix, $m$, and competitive position, $c$. For the industry sector $i$ in region $j$, it takes the following form:

$$
\mathrm{d}_{\mathrm{ij}}=\mathrm{g}_{\mathrm{il}}+\mathrm{m}_{\mathrm{ij}}+\mathrm{c}_{\mathrm{ij}} \cdot
$$

\subsubsection{Overview of results for voivodeships}

In 2008, the highest share in employment was witnessed (in descending order) by Mazowieckie, Śląskie, Łódzkie, Małopolskie and Wielkopolskie. Until 2018, Wielkopolskie moved to the third position while Łódzkie dropped out of the top five regions in terms of employment distribution. Pomorskie advanced to the $7^{\text {th }}$ position $\left(9^{\text {th }}\right.$ in 2008), followed by Kujawsko-Pomorskie ( $10^{\text {th }}$ rank in 2008), Lubelskie ( $7^{\text {th }}$ in 2008$)$, and Podkarpackie closing the top ten voivodeships with the highest shares in employment. Table 1 shows that over the past ten years the most visible increase in the share of employment was recorded in two regions: Wielkopolskie and Pomorskie. Interestingly, Mazowieckie increased its number of people in employment but lost its share in total employment by $0.5 \mathrm{pp}$.

Table 10.1. Employment by region (thousands) and the share of total employment (\%), 2008 and 2018

\begin{tabular}{|l|r|r|r|c|}
\cline { 2 - 5 } \multicolumn{1}{c|}{2008} & 2018 & \begin{tabular}{c} 
\% of total employment, \\
\multicolumn{1}{c|}{}
\end{tabular} & \multicolumn{2}{c|}{$\begin{array}{c}\text { Change in percentage } \\
\text { points }\end{array}$} \\
\hline Małopolskie & 1296.4 & 1409.2 & 8.7 & 0.4 \\
\hline Śląskie & 1808.6 & 1843.7 & 11.4 & -0.2 \\
\hline Wielkopolskie & 1287.2 & 1575.8 & 9.8 & 1.5 \\
\hline Zachodniopomorskie & 560.6 & 692.9 & 4.3 & 0.7 \\
\hline Lubuskie & 411.6 & 417.0 & 2.6 & -0.1 \\
\hline Dolnośląskie & 1140.8 & 1210.5 & 7.5 & 0.2 \\
\hline Opolskie & 380.9 & 395.7 & 2.5 & 0.0 \\
\hline Kujawsko-Pomorskie & 726.8 & 856.7 & 5.3 & 0.6 \\
\hline Warmińsko-Mazurskie & 555.6 & 547.4 & 3.4 & -0.2 \\
\hline Pomorskie & 787.5 & 984.9 & 6.1 & 1.0 \\
\hline Łódzkie & 1316.5 & 1095.8 & 6.8 & -1.7 \\
\hline Świętokrzyskie & 576.3 & 494.2 & 3.1 & -0.6 \\
\hline
\end{tabular}




\begin{tabular}{|l|c|c|c|c|}
\cline { 2 - 5 } \multicolumn{1}{c|}{} & 2008 & 2018 & \begin{tabular}{c} 
\% of total employment, \\
\multicolumn{1}{c|}{}
\end{tabular} & $\begin{array}{c}\text { Change in percentage } \\
\text { points }\end{array}$ \\
\hline Lubelskie & 944.9 & 855.0 & 5.3 & -0.8 \\
\hline Podkarpackie & 835.6 & 817.6 & 5.1 & -0.3 \\
\hline Podlaskie & 487.3 & 480.2 & 3.0 & -0.2 \\
\hline Mazowieckie & 2440.8 & 2456.8 & 15.2 & -0.5 \\
\hline
\end{tabular}

Source: Author's own calculations based on Eurostat data, Employment by age, economic activity and NUTS 2 regions (NACE Rev. 2), https://ec.europa.eu/eurostat/web/lfs/data/database (25.10.2019).

Table 10.2. Shift-share analysis by region and sector - industry (except construction) and services, 2008-2018

\begin{tabular}{|c|c|c|c|c|c|c|c|c|}
\hline & \multicolumn{4}{|c|}{ Services } & \multicolumn{4}{|c|}{ Industry (except construction) } \\
\hline Region NUTS 2 & $\begin{array}{l}\frac{0}{\frac{1}{0}} \\
\frac{\pi}{n} \\
\frac{\pi}{0} \\
\frac{0}{0} \\
\frac{0}{\pi} \\
Z\end{array}$ & 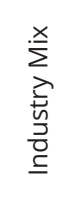 & 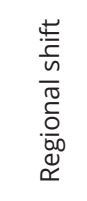 & 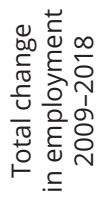 & $\begin{array}{l}\frac{0}{\frac{0}{0}} \\
\frac{c}{n} \\
\frac{\pi}{0} \\
\frac{c}{0} \\
\frac{0}{\pi} \\
\frac{\pi}{Z}\end{array}$ & 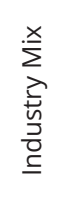 & 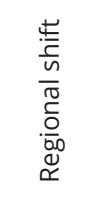 & 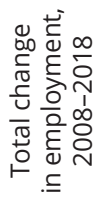 \\
\hline Małopolskie & 15.4 & 33.7 & 27.5 & 76.6 & 10.7 & -0.4 & 33.5 & 43.8 \\
\hline Śląskie & 22.9 & 49.9 & -69.2 & 3.6 & 21.8 & -0.8 & -13.4 & 7.5 \\
\hline Wielkopolskie & 13.3 & 29.1 & 107.3 & 149.7 & 13.6 & -0.5 & 82.1 & 95.2 \\
\hline Zachodniopomorskie & 7.2 & 15.8 & 20.7 & 43.7 & 4.6 & -0.2 & 20.7 & 25.1 \\
\hline Lubuskie & 4.4 & 9.6 & -2.1 & 11.9 & 4.3 & -0.2 & -3.0 & 1.1 \\
\hline Dolnośląskie & 14.0 & 30.5 & 24.6 & 69.1 & 13.1 & -0.5 & -50.4 & -37.8 \\
\hline Opolskie & 3.8 & 8.4 & -12.3 & -0.1 & 3.8 & -0.1 & 3.7 & 7.4 \\
\hline Kujawsko-Pomorskie & 7.9 & 17.2 & 28.8 & 53.8 & 7.0 & -0.3 & 21.3 & 28.0 \\
\hline Warmińsko-Mazurskie & 6.1 & 13.3 & -34.5 & -15.0 & 4.9 & -0.2 & -6.1 & -1.4 \\
\hline Pomorskie & 9.9 & 21.5 & 50.7 & 82.1 & 7.5 & -0.3 & 5.7 & 12.9 \\
\hline Łódzkie & 14.5 & 31.6 & -69.5 & -23.4 & 12.4 & -0.5 & -51.6 & -39.6 \\
\hline Świętokrzyskie & 5.2 & 11.4 & -16.2 & 0.4 & 4.8 & -0.2 & -26.8 & -22.1 \\
\hline Lubelskie & 8.8 & 19.2 & -9.1 & 18.9 & 5.6 & -0.2 & -23.1 & -17.7 \\
\hline Podkarpackie & 8.7 & 19.0 & -22.5 & 5.2 & 7.4 & -0.3 & 20.0 & 27.2 \\
\hline Podlaskie & 4.9 & 10.7 & -13.0 & 2.6 & 3.0 & -0.1 & 6.1 & 9.0 \\
\hline Mazowieckie & 34.1 & 74.4 & -26.7 & 81.7 & 15.7 & -0.6 & -18.5 & -3.4 \\
\hline
\end{tabular}

* Wholesale and retail trade, transport, accommodation and food service activities, information and communication, financial and insurance activities, professional, scientific and technical activities, administrative and support service activities. Source: Ibidem.

The most significant gains in employment in the service sector were observed for Wielkopolskie, Pomorskie and Mazowieckie, followed by Małopolskie, Dolnośląskie and Kujawsko-Pomorskie (See: Table 10.2). For all these voivodeships (but for Mazowieckie), 
the regional shift was the strongest component of this change. The industry mix factor was in general stronger than the national share component among these voivodeships; however, the national growth was especially favorable for Mazowieckie. The results for the above-mentioned top three voivodeships show some intriguing patterns. For Wielkopolskie and Pomorskie, national shift and industry mix were close to the average for all 16 regions (11.3 and 24.7, respectively), yet the values of the regional shift variable (a region's competitiveness) outperformed other regions substantially (107.3 for Wielkopolskie and 50.7 for Pomorskie). Interestingly, the regional shift for Mazowieckie turned out to be negative. The result was the fourth from the bottom, just after Łódzkie, Śląskie and Warmińsko-Mazurskie.

For the industry sector, the highest changes in employment were observed for Wielkopolskie, Małopolskie and Kujawsko-Pomorskie. For all these three voivodeships, the competitiveness parameter was positive and stronger than the remaining two components. In the case of the industry sector, the industry mix component was negative for all the 16 regions, ranging from -0.1 for Podlaskie to -0.8 for Śląskie, while the national shift was positive and the strongest for Śląskie, Mazowieckie and Wielkopolskie.

Looking at the disaggregated data for the service sector in Wielkopolskie, Pomorskie and Mazowieckie, it should be noted that in Wielkopolskie employment creation was the most intensive in wholesale and retail trade, transport and accommodation and food service activities (accounting for $24 \%$ of the region's total employment in 2018). Decomposition of this change demonstrates a strong regional shift (86\%) for wholesale and retail trade, supported by the national shift (10.6\%) and a weak industry mix (3.5\%). A similar situation was seen in Pomorskie, where, also in 2018, 24\% of the region's total employment was attributable to wholesale and retail trade, transport and accommodation and food service activities. The regional shift for these sectors accounted for $74 \%$, the national shift for $20 \%$, and the industry mix for $6.5 \%$ of the total change in employment in Pomorskie during the time in question. Mazowieckie saw a decrease in employment in the above-mentioned sectors, for which the negative regional shift surpassed the positive impacts of the national share and the industry mix. The highest growth in employment was reported in professional, scientific and technical activities, and administrative and support service activities, which was almost fully explained by a favorable industrial structure.

The information and communication sector showed the highest gain in employment in Mazowieckie. The increase was generated by the industry mix negatively affected by weakening competitiveness. The following four regions also manifested a visible growth in this sector: Dolnośląskie, Małopolskie, Wielkopolskie and Pomorskie, for which the change was in half explained by the regional shift and in half by the industry mix. 


\subsubsection{Overview of results for occupations}

During the decade from 2008 to 2018, the most dynamic increase in the number of employed persons in both analyzed sectors, services and manufacturing, could be found for professionals. Over ten years, this occupational group grew by $78 \%$ in services and by $64 \%$ in manufacturing (see: Table 3 ). The following three sub-sectors were responsible for the significant increase in professionals in services: accommodation and food service activities, administrative and support service activities, and transportation and storage.

Table 10.3. Employment dynamics by occupational group and by service and manufacturing sectors, 2008-2018

\begin{tabular}{|c|c|c|c|c|c|c|c|c|}
\hline & \multicolumn{4}{|c|}{ Service sector* } & \multicolumn{4}{|c|}{ Manufacturing } \\
\hline Occupation & 2008 & 2018 & 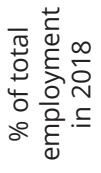 & $\begin{array}{c}\% \\
\text { change }\end{array}$ & 2008 & 2018 & 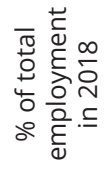 & $\begin{array}{c}\% \\
\text { change }\end{array}$ \\
\hline Managers & 480.0 & 423.4 & 41.4 & -11.8 & 190.3 & 221.8 & 16.6 & 21.7 \\
\hline Professionals & 597.4 & 1063.5 & 32.4 & 78.0 & 176.7 & 290.1 & 8.8 & 64.2 \\
\hline Technicians & 636.2 & 723.1 & 32.8 & 13.7 & 292.4 & 461.8 & 21.0 & 57.9 \\
\hline Clerical workers & 554.7 & 476.0 & 47.6 & -14.2 & 171.8 & 206.1 & 20.6 & 20.0 \\
\hline $\begin{array}{l}\text { Service and sales } \\
\text { workers }\end{array}$ & 1512.5 & 1645.5 & 75.9 & 8.8 & 29.7 & 47.0 & 2.2 & 58.2 \\
\hline Craft trades & 253.2 & 267.4 & 10.7 & 5.6 & 1307.5 & 1274.0 & 50.9 & -2.6 \\
\hline Plant operators & 589.9 & 645.0 & 38.3 & 9.3 & 773.2 & 714.8 & 42.4 & -7.6 \\
\hline Elementary occupations & 297.9 & 291.0 & 28.9 & -2.3 & 285.6 & 228.4 & 22.7 & -20.0 \\
\hline
\end{tabular}

* The service sector includes wholesale and retail trade; repair of motor vehicles and motorcycles, transportation and storage, accommodation and food service activities, information and communication, financial and insurance activities, professional, scientific and technical activities, administrative and support service activities.

Source: Compiled by author based on data from Eurostat, Labor Force Survey, https://ec.europa.eu/eurostat/web/lfs/ data/database (7.10.2019).

The order by growth dynamics in remaining seven occupational groups varied for the service and manufacturing sectors. In the case of the former, the following four groups recorded increases: technicians (13.7\%), plant operators (9.3\%), service and sales workers (8.8\%), and craft trades (5.6\%). At the bottom of the list, there were three occupations that reported declines: elementary occupations $(-2.3 \%)$, managers $(-11.8 \%)$, and clerical workers $(-14 \%)$.

In manufacturing. the growth of the following professions was more dynamic: service and sales workers (58.2\%), technicians (58\%), managers (21.6\%), and clerical 
workers $(20 \%)$. The drops were recorded in craft trades $(-2.5 \%)$, plant operators (7.6\%) and elementary occupations (20\%).

Between 2008 and 2018, the manufacturing sector saw a visible upgrade towards high-skilled labor, while the service sector absorbed more medium-skilled workers during that time. Interestingly, services saw the highest drop in the manager occupational group, while manufacturing reported a downward shift in elementary occupations.

Table 10.4. Shift-share analysis for occupational groups by sector - services and manufacturing (2008-2018)

\begin{tabular}{|c|c|c|c|c|c|}
\hline Sector & Occupational group* & $\begin{array}{l}\text { National } \\
\text { Share }\end{array}$ & $\begin{array}{c}\text { Industry } \\
\text { Mix }\end{array}$ & $\begin{array}{c}\text { Occupational } \\
\text { Shift }\end{array}$ & $\begin{array}{c}\text { Total change } \\
\text { in employment } \\
2008-2018\end{array}$ \\
\hline \multirow{8}{*}{$\begin{array}{l}\frac{1}{0} \\
\stackrel{U}{d} \\
u \\
0 \\
\stackrel{U}{2} \\
\frac{1}{d} \\
\sim\end{array}$} & Managers & 17.8 & 38.8 & -113.2 & -56.6 \\
\hline & Professionals & 22.1 & 48.3 & 395.7 & 466.1 \\
\hline & Technicians & 23.6 & 51.4 & 11.9 & 86.9 \\
\hline & Clerical workers & 20.5 & 44.8 & -144.1 & -78.7 \\
\hline & Service and sales workers & 56.0 & 122.3 & -45.3 & 133 \\
\hline & Craft trades workers & 9.4 & 20.5 & -15.6 & 14.2 \\
\hline & Plant operators & 21.8 & 47.7 & -14.4 & 55.1 \\
\hline & Elementary occupations & 11.0 & 24.1 & -42.0 & -6.9 \\
\hline \multirow{8}{*}{ 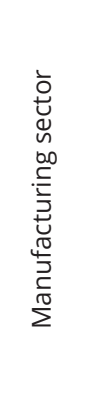 } & Managers & 7.0 & 5.0 & 19.4 & 31.5 \\
\hline & Professionals & 6.5 & 4.7 & 102.2 & 113.4 \\
\hline & Technicians & 10.8 & 7.8 & 150.8 & 169.4 \\
\hline & Clerical workers & 6.4 & 4.6 & 23.4 & 34.3 \\
\hline & Service and sales workers & 1.1 & 0.8 & 15.4 & 17.3 \\
\hline & Craft trades workers & 48.4 & 34.7 & -116.6 & -33.5 \\
\hline & Plant operators & 28.6 & 20.5 & -107.5 & -58.4 \\
\hline & Elementary occupations & 10.6 & 7.6 & -75.3 & -57.2 \\
\hline
\end{tabular}

* Craft trades (accommodation and food services, financial and insurance activities), plant operators (accommodation and food service activities, information and communication, financial and insurance activities, professional, scientific and technical activities), elementary occupations (information and communication, financial and insurance activities); lack of data for some sectors.

Source: Ibidem.

As a result of the occupational analysis based on shift-share calculations, several interesting facts can be noticed. In both sectors and in all occupation groups, the national share and industry mix indicators show a positive sign. For the service sector, the mean was higher for the industrial structure parameter, suggesting that the expected growth in occupation groups was explained by the expansion of a specific industry, e.g., for highly skilled workers, i.e., managers, professionals and technicians, 
this growth was evidently higher for professional, scientific and technical activities, and for information and communication, whereas for medium-skilled workers a similar regularity was found in transportation and storage, and accommodation and food service activities, while for low-skilled workers this was the case in accommodation and food service activities, and in administrative and support service activities. However, the occupational shift turned out to be positive for two occupations only: professionals and technicians, implying that these professions are the most competitive nowadays in Poland's service sector.

In the case of the manufacturing sector, the national shift was, on average, stronger than the industry mix component, showing that the expected growth in all occupation groups can be explained by the national economic development. The values of the occupational shift demonstrate high competitiveness of professions such as technicians, professionals and managers, but also of the occupations placed in the upper part of the medium-skilled workers distribution. For both the manufacturing and the service sectors, elementary occupations displayed a positive national shift and industry mix factors outperformed by a negative occupational shift resulting in a drop in employment in this occupational group.

\subsection{Conclusions}

During the past decade, Poland has experienced a significant increase in the share of highly educated workers in total employment. This fact was accompanied by a relative decline in medium- and low-skilled labor. Looking into more detailed data split into the service and manufacturing sectors, it can be observed that highly educated workers (professionals and technicians) were sought after especially in manufacturing. Additionally, although medium-skilled labor has been, on average, in less demand, occupations from the group's top distribution have also grown in the manufacturing sector during the past decade. On the other hand, the service sector was less dynamic in terms of changes in occupations, hiring high-skilled workers and labor from the bottom of the medium-skilled workers distribution (trades workers). Data analysis and shift-share decomposition based on occupation groups suggest that it is rather upskilling than occupation or employment polarization that has been recently present in Poland.

Furthermore, at the regional level, the growing role of the service sector in Wielkopolskie and Pomorskie, followed by Małopolskie, Dolnośląskie and Kujawsko-Pomorskie, call for more detailed analyses and the development of skill monitoring instruments. 


\section{References}

Acemoglu, D. (2002), Technical Change, Inequality, and The Labor Market, "Journal of Economic Literature", vol. 40, pp. 7-72.

Acemoglu, D., Autor, D. (2011), Skills, Tasks and Technologies: Implications for Employment and Earnings, in: Handbook of Labor Economics, O. Ashenfelter, D. Card (eds.), vol. 4b, North Holland, pp. 1043-1171.

Autor, D., Levy, F., Murnane, R. (2003), The skill content of recent technological change: An empirical exploration, "The Quarterly Journal of Economics", vol. 118, pp. 1279-1333.

Berman, E., Bound, J., Griliches, Z. (1994), Changes in the Demand for Skilled Labor within U.S. Manufacturing: Evidence from the Annual Survey of Manufacturers, "The Quarterly Journal of Economics", vol. 109(2), pp. 367-397.

Bárány, Z.L., Siegel, Ch. (2018), Job Polarization and Structural Change, "American Economic Journal: Macroeconomics", vol. 10(1), pp. 57-89.

Cirillo, V. (2018), Job polarization in European industries, "International Labour Review", vol. 157(1).

Fonesca, T., Lima, F., Pereira, S.C. (2018), Job polarization, technological change and routinization: Evidence for Portugal, "Labour Economics", vol. 51, pp. 317-339.

Goos, M., Manning, A. (2007), Lousy and Lovely Jobs: The Rising Polarization of Work in Britain, "The Review of Economics and Statistics", vol. 89(1), pp. 118-133.

Goos, M., Manning, A., Salomons A. (2014), Explaining Job Polarization: Routine-Biased Technological Change and Offshoring, "American Economic Review", 104(8), pp. 2509-26.

GUS (2019), Polska - roczne wskaźniki makroekonomiczne, https://stat.gov.pl/en/poland-macroeconomic-indicators/ (7.10.2019).

Herzog, W., H., Olsen, R., J. (1977), Shift-share analysis revisited: the allocation effect and the stability of regional structure, Regional and Urban Studies Section, Energy Division, Oak Ridge National Laboratory, Oak Ridge.

Kupets, O. (2014), Education-job mismatch in Ukraine: Too many people with tertiary education or too many jobs for low-skilled?, "Journal of Comparative Economics", vol. 44(2016), pp. 125-147.

Michaels, G., Natraj, A., Van Reen, J. (2014). Has ICT Polarized Skill Demand? Evidence from Eleven Countries over Twenty-Five Years, "The Review of Economics and Statistics", vol. 96(1), pp. 60-77. 
Chapter 11

\section{Changes in Total Factor Productivity, with a Particular Focus on the Service Sector}

Mariusz Próchniak

\subsection{Introduction}

The analysis of total factor productivity has been carried out using growth accounting. Growth accounting is an empirical exercise aimed at determining to what extent economic growth results from changes in the measurable production factors and from changes in the level of technology, measured by the growth rate of total factor productivity (TFP).

This analysis at the level of the entire economy covers 11 countries of Central and Eastern Europe, namely the EU-11 group (Poland, Bulgaria, Croatia, the Czech Republic, Estonia, Lithuania, Latvia, Romania, Slovakia, Slovenia, and Hungary) and the period 2010-2019. To assess the dynamics of changes in total factor productivity in the specified timespan, we also present the average TFP growth rate values for the following sub-periods: 2010-2012, 2013-2015, 2016-2018, and for 2019.

In this edition of the study, the standard analysis is expanded by the economic growth account at sector level. This allowed changes in total factor productivity in different sectors of the economy, including the service sector, to be assessed. The sectoral analysis presents results for Poland vis-à-vis selected countries of Central and Eastern Europe and Western Europe in 2010-2018.

\subsection{Changes in Total Productivity - Theoretical Background}

The origins of growth accounting date back to the first half of the 20th century. The concept of total productivity and the view that labor is not the only production factor, and that in measuring wealth of nations and productivity one should take into account other assets such as capital and land, were discussed in the economic literature 
in the $1930 \mathrm{~s}$ [Griliches, 1996]. The first mentions of the input-output ratio appeared in Copeland's paper in 1937. [Griliches, 1996]. In the $1940 \mathrm{~s}$ and '50 s, many studies were published - to large extent independently - which included results of empirical research on TFP measurement. The first such study, conducted by Dutch economist Jan Tinbergen, was published in 1942. In the following years, further studies appeared, in which the authors examined the relationship between the volume of output and the inputs [see, e.g. Tintner, 1944; Barton and Cooper, 1948; Johnson, 1950; Schmookler, 1952; Abramovitz, 1956; Kendrick, 1956; Ruttan, 1956].

Robert Solow was the first economist to formalize growth accounting [Solow, 1957]. Using the macroeconomic production function and differential calculus, he showed how the rate of economic growth can be divided into the part resulting from an increase in factors of production and the remaining part, referred to as Solow's residual. The latter indicates what part of economic growth cannot be attributed to individual factors. Thus, it is a measure of technological progress, or TFP growth.

In the following years, further studies on growth accounting appeared, introducing new approaches and extensions of previously conducted research, and containing new elements of empirical analysis [see, e.g., Solow, 1962; Griliches, 1964; Jorgenson and Griliches, 1967].

The decomposition of economic growth initiated by Solow forms the basis of modern growth accounting. The starting point of such an analysis is the macroeconomic production function. Its general form is as follows:

$$
Y(t)=F\left(A(t), Z_{1}(t), \ldots, Z_{n}(t)\right)
$$

where $Y$ - output (GDP), $A$ - level of technology, $Z_{1}, \ldots, Z_{n}$ - measurable factors of production. Two or three measurable factors of production are usually taken into account in empirical research, namely: labor, physical capital, and possibly human capital.

The analysis presented in this edition of the report will be carried out with the use of two measurable factor inputs: labor and physical capital. The production function (11.1) therefore takes the following form:

$$
Y(t)=F(A(t), L(t), K(t))
$$

In order to decompose the rate of economic growth into individual components, equation (11.2) should be transformed into a form representing the growth rate of $Y$. For this purpose, we differentiate (11.2) with respect to time and then divide by $Y$. As a result, we obtain: 


$$
\frac{\dot{Y}}{Y}=\frac{\frac{\partial F(A, L, K)}{\partial A} \dot{A}}{Y}+\frac{\frac{\partial F(A, L, K)}{\partial L} \dot{L}}{Y}+\frac{\frac{\partial F(A, L, K)}{\partial K} \dot{K}}{Y}
$$

After multiplying the individual components on the right-hand side of equation (11.3) by $A / A, L / L$ and $K / K$, respectively, we get:

$$
\frac{\dot{Y}}{Y}=\frac{\frac{\partial F(A, L, K)}{\partial A} A}{Y} \frac{\dot{A}}{A}+\frac{\frac{\partial F(A, L, K)}{\partial L} L}{Y} \frac{\dot{L}}{L}+\frac{\frac{\partial F(A, L, K)}{\partial K} K}{Y} \frac{\dot{K}}{K} .
$$

Equation (11.4) shows that the GDP growth rate is the weighted average of growth rates of three factors: technology, labor and physical capital. The weights are the shares of individual factors in GDP, measured as the marginal product of the factor (at the level of the entire economy) multiplied by the amount of a given factor and divided by the volume of output.

\subsection{Method}

The research method used in the analysis presented in this chapter is economic growth accounting. In order to be able to calculate the TFP growth rate in an empirical study, additional assumptions should be made to equation (11.4) that shows the essence of economic growth accounting.

We assume, firstly, that the production function is characterized by Hicks-neutral technological progress. Thus, this function can be described as follows:

$$
F(A, L, K)=A \cdot f(L, K)
$$

As can be seen, Hicks-neutral technological progress means that variable $A$, representing the level of technology, occurs in the product with production function $f$, making the production volume dependent on measurable inputs. Technological progress augments both production factors to the same extent, without changing the marginal rate of technological substitution between them. In the case of the production function (11.5), the share of technology in income, i.e. the component $(\partial F / \partial A) A / Y$ in equation (11.4), equals 1. Equation (11.4) can then be written as:

$$
\frac{\dot{Y}}{Y}=\frac{\dot{A}}{A}+\frac{\frac{\partial F(A, L, K)}{\partial L} L}{Y} \frac{\dot{L}}{L}+\frac{\frac{\partial F(A, L, K)}{\partial K} K}{Y} \frac{\dot{K}}{K} .
$$


The above equation shows that the rate of economic growth equals the sum of technological progress (increase in TFP) and the average growth rate of labor and physical capital, weighted by the shares of both factors in income.

An additional assumption should also be made, regarding the marginal products of both factors. The marginal product of labor and capital at the level of the entire economy is in fact nonmeasurable. We therefore assume that all markets are perfectly competitive and that no externalities exist. In this case, the marginal product of capital $\partial F / \partial K$ equals the price of capital $r$, while the marginal product of labor $\partial F / \partial L$ corresponds to the wage rate $w$. By using $s_{K}$ to describe the capital share in income $(r K / Y)$, and $s_{L}$ to describe the share of labor $(w L / Y)$, equation (11.6) can be written as:

$$
\frac{\dot{Y}}{Y}=\frac{\dot{A}}{A}+s_{K} \frac{\dot{K}}{K}+s_{L} \frac{\dot{L}}{L} .
$$

Let us make an additional assumption that all income can be assigned to one of two factors of production: labor or physical capital, i.e. $Y=w L+r K$. In this case, the shares of labor and physical capital in income add up to $1: s_{K}+s_{L}=1$. Thus, formula (11.7) takes the following form:

$$
\frac{\dot{Y}}{Y}=\frac{\dot{A}}{A}+s_{K} \frac{\dot{K}}{K}+\left(1-s_{K}\right) \frac{\dot{L}}{L} .
$$

Equation (11.8) ${ }^{1}$ is the basis for standard growth accounting. On this basis, the TFP growth rate can be calculated as the difference between the GDP growth rate and the weighted average growth rate of both factors of production:

$$
\text { TFP growth } \equiv \frac{\dot{A}}{A}=\frac{\dot{Y}}{Y}-\left[s_{K} \frac{\dot{K}}{K}+\left(1-s_{K}\right) \frac{\dot{L}}{L}\right] .
$$

\subsection{Empirical Evidence at the Level of the Entire Economy}

For the purposes of the analysis, we have gathered data that form the following time series: a) the rate of economic growth, b) the rate of change in labor inputs, c) the rate of change in physical capital input. The rate of economic growth is the annual growth rate of total real GDP, sourced from the IMF database [IMF, 2020]. The rate of change in labor inputs is measured using the employment dynamics data provided by the International Labor Organization [ILO, 2020]. The 2019 data cover the first three

1 This equation is in fact a Cobb-Douglas production function. 
quarters (in order to avoid seasonality, the rate of change in labor inputs for 2019 is calculated by comparing the employment level in the first three quarters of 2019 with the employment level in the first three quarters of 2018). We calculated the time series of the physical capital stock on the basis of the perpetual inventory method using the World Bank data [World Bank, 2020]. This method requires taking into account many assumptions. We have assumed that the depreciation rate is $5 \%$ and the initial capital/output ratio is 3 . In the perpetual inventory method, the initial year should be a little earlier than the years for which TFP is being calculated; in our study, we start calculations in 2000, which is the year to which the assumption of capital to output ratio of 3 applies. As investments, we use a variable measuring gross fixed capital formation. The shares of labor and physical capital in income in each case equal $1 / 2$.

In this edition of the study, we have updated all the time series of the analyzed variables. The analysis has been recalculated. Therefore, the documentation of the results has been fully presented in this chapter and it does not duplicate the information contained in the previous editions of the Report [Próchniak, 2019].

In Table 11.1, detailed results of economic growth decomposition are presented, while Tables 11.2 and 11.3 summarize the data from Table 11.1.

Lithuania recorded the highest TFP growth rate (1.9\% annually) over the entire period. At the same time, it was higher by only $0.1 \mathrm{pp}$ than the TFP growth rate observed in Latvia and Poland, which took a joint second place in productivity dynamics. Poland's results (second place among EU-11 countries) should be considered a success. If taken as an approximate measure of technological progress, changes in TFP place Poland among the EU-11 leaders in creating new technologies.

Apart from Lithuania, Latvia and Poland, also five other EU-11 countries recorded a productivity growth rate above 1\% over the 2010-2019 period: Romania, where TFP was seen to grow at an average rate of $1.7 \%$ annually, as well as Estonia (1.5\%), Slovenia (1.4\%), Slovakia (1.2\%), and Bulgaria (1.1\%). In the remaining three EU-11 countries, productivity dynamics did not exceed the annual average of $1 \%$. Over the entire 10-year period, Hungary reported an average decline in TFP by $0.8 \%$, and the Czech Republic and Croatia by $0.5-0.6 \%$ annually.

We assume that TFP growth is an approximate measure of technological progress. However, calculating it using the residual method on the basis of growth accounting has its drawbacks as an indicator of technological growth, which should be kept in mind when interpreting results. For example, the part of TFP which results from increased labor productivity should be partially considered as contribution of human capital to economic growth. Due to the difficulties in calculating this type of capital in the case of the analyzed group of countries, TFP in our approach also takes into account the impact of human capital on economic growth. 
Table 11.1. The contribution of labor, physical capital and TFP to economic growth in 2009-2019

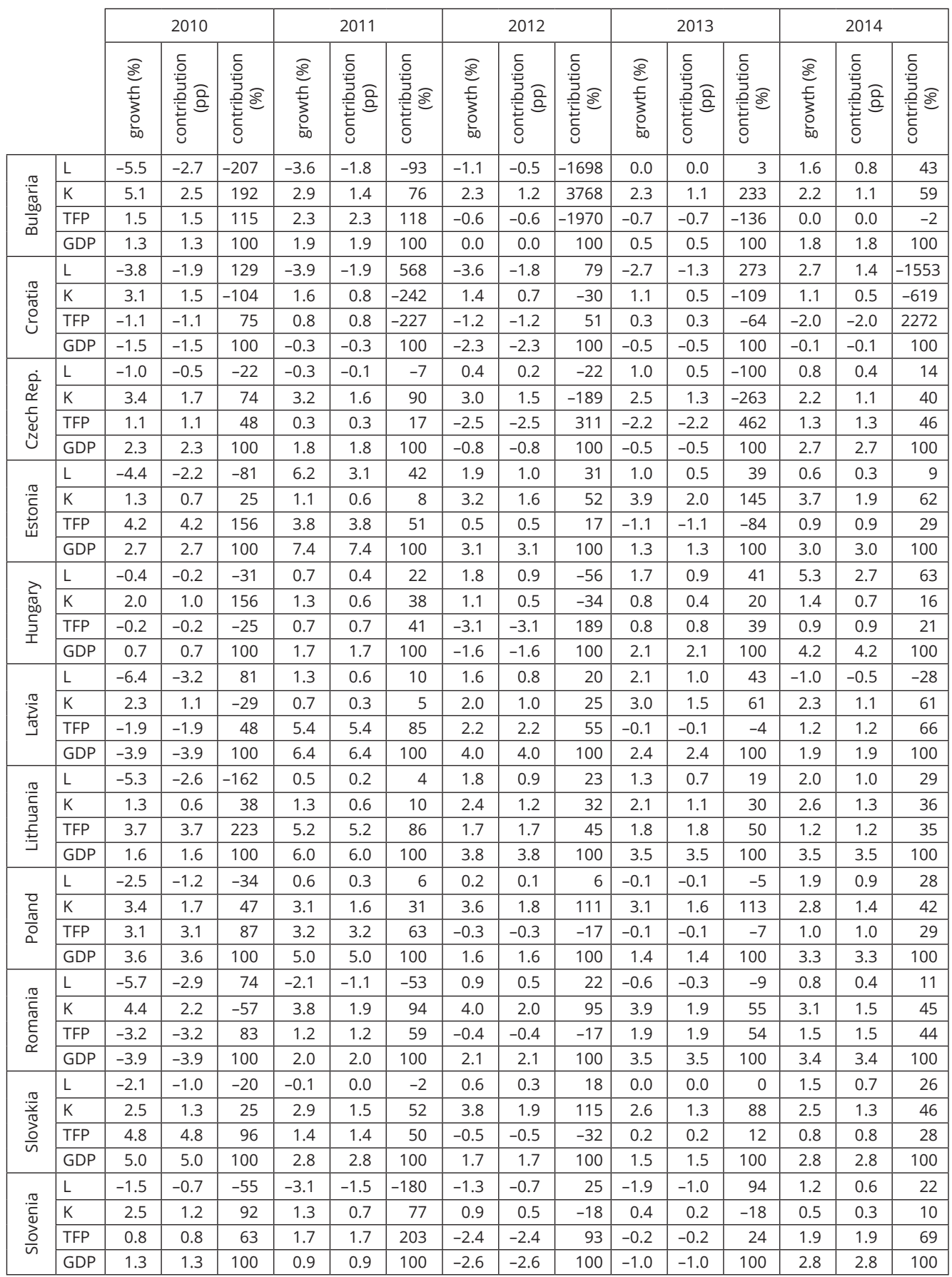




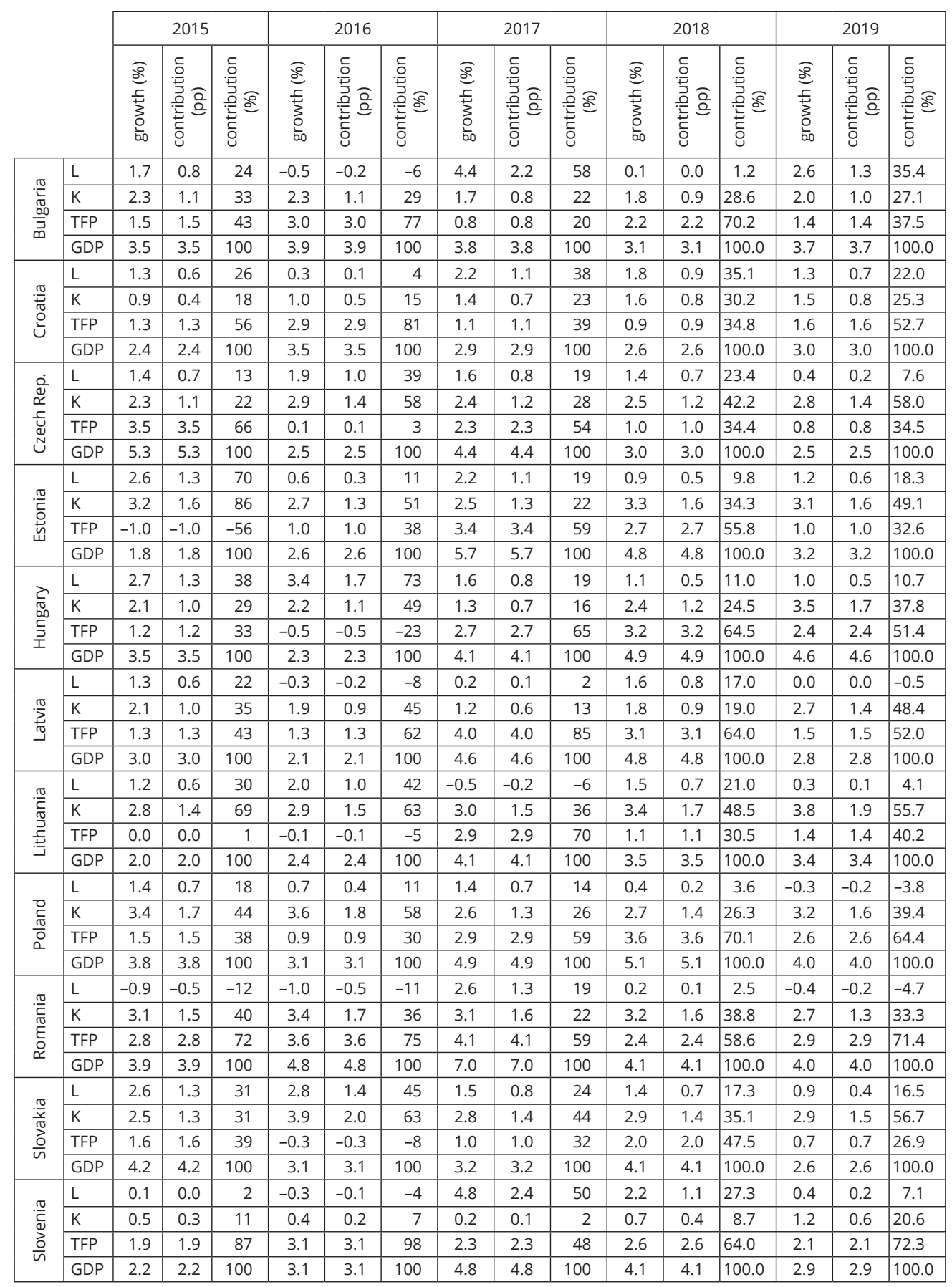

Source: Own calculations. 
Table 11.2. TFP growth rate (in \%)

\begin{tabular}{|c|c|c|c|c|c|c|c|}
\hline \multirow{2}{*}{ Country } & \multicolumn{3}{|c|}{ Entire period 2010-2019 } & \multirow{2}{*}{$\begin{array}{c}\text { 2010-2012 } \\
\text { average }\end{array}$} & \multirow{2}{*}{$\begin{array}{c}2013-2015 \\
\text { average }\end{array}$} & \multirow{2}{*}{$\frac{2016-2018}{\text { average }}$} & \multirow{2}{*}{2019} \\
\hline & average & minimum & maximum & & & & \\
\hline Bulgaria & 1.1 & -0.7 & 3.0 & 1.1 & 0.3 & 2.0 & 1.4 \\
\hline Croatia & 0.5 & -2.0 & 2.9 & -0.5 & -0.1 & 1.6 & 1.6 \\
\hline Czech Republic & 0.6 & -2.5 & 3.5 & 0.4 & 0.8 & 1.1 & 0.8 \\
\hline Estonia & 1.5 & -1.1 & 4.2 & 2.8 & 0.4 & 2.4 & 1.0 \\
\hline Hungary & 0.8 & -3.1 & 3.2 & -0.9 & 1.0 & 1.8 & 2.4 \\
\hline Latvia & 1.8 & -1.9 & 5.4 & 1.9 & 0.8 & 2.8 & 1.5 \\
\hline Lithuania & 1.9 & -0.1 & 5.2 & 3.5 & 1.0 & 1.3 & 1.4 \\
\hline Poland & 1.8 & -0.3 & 3.6 & 2.0 & 0.8 & 2.5 & 2.6 \\
\hline Romania & 1.7 & -3.2 & 4.1 & -0.8 & 2.1 & 3.4 & 2.9 \\
\hline Slovakia & 1.2 & -0.5 & 4.8 & 1.9 & 0.8 & 0.9 & 0.7 \\
\hline Slovenia & 1.4 & -2.4 & 3.1 & 0.1 & 1.2 & 2.7 & 2.1 \\
\hline
\end{tabular}

Source: Own calculations.

Table 11.3. Contribution of TFP to economic growth (\%)

\begin{tabular}{|l|c|c|c|}
\hline \multirow{2}{*}{ Country } & \multicolumn{3}{|c|}{ Entire period 2010-2019 } \\
\cline { 2 - 4 } & average & minimum & maximum \\
\hline Bulgaria & -163 & -1970 & 118 \\
\hline Croatia & 237 & -227 & 2272 \\
\hline Czech Republic & 107 & 3 & 462 \\
\hline Estonia & 30 & -84 & 156 \\
\hline Hungary & 46 & -25 & 189 \\
\hline Latvia & 56 & -4 & 85 \\
\hline Lithuania & 58 & -5 & 223 \\
\hline Poland & 42 & -17 & 87 \\
\hline Romania & 56 & -17 & 83 \\
\hline Slovakia & 29 & -32 & 96 \\
\hline Slovenia & 82 & 24 & 203 \\
\hline
\end{tabular}

Source: Own calculations.

Poland's very good performance in terms of changes in total factor productivity compared with the EU-11 are a great success. The Baltic states were the leaders in TFP dynamics in the analyses prepared a few years ago. Prior to the global crisis, they showed a very fast economic growth, which was difficult to explain by changes in labor and physical capital, which is why it was attributed to TFP. The position of Poland in those 
analyses was moderate - not as good as that of the Baltic states, nor the worst in the group. The extension and shifting of the time horizon significantly changed the outcomes for individual countries in favor of Poland.

The greatest fluctuations of TFP growth rates over the analyzed period were witnessed in Latvia and Romania. The differentiation of the dynamics of productivity changes in these countries results partly from large spreads of GDP growth rates. The difference between the highest and the lowest TFP growth rate in 2010-2019 reported at $7.3 \mathrm{pp}$ in Latvia and Romania. In other countries of Central and Eastern Europe, except for Poland and Bulgaria, the spread of TFP growth rates ranged at approx. 5-6 pp. In Poland and Bulgaria, the difference between the highest and the lowest rate was the smallest at less than $4 \mathrm{pp}$. The latter result is another reason why Poland's achievements regarding changes in total factor productivity should be viewed as a positive development. In addition to the fact that Poland recorded a fast growth rate of productivity in the last 10 years, it is worth noting that it very stable compared to other Central and Eastern European countries. In Poland, the lowest TFP growth rate in the analyzed period occurred in $2012(-0.3 \%)$, and the highest - in 2018 (3.6\%).

The data for the individual sub-periods show that the years under study saw - in general - an accelerated rate of TFP growth, while the process was not a rule and varied in scale between countries. In 2010-2012, four countries of the group concerned (Czech Republic, Croatia, Romania, and Hungary) recorded a negative TFP growth rate. Of course, the TFP decline can hardly be treated as a technological regression - this result is a consequence of using the residual method of TFP calculation. Nevertheless, its negative values do not imply success in terms of productivity changes for these four countries. In the following sub-period (2013-2015), only two countries (Croatia and Estonia) recorded negative TFP dynamics. In later years, there was a further improvement in terms of changes in total factor productivity and as a result, in the 2016-2018 sub-period and in 2019, no EU-11 country achieved a negative growth rate of TFP.

In terms of TFP dynamics, Poland's position improved in 2010-2019. In the initial sub-periods (2010-2012 and 2013-2015), the average rate of TFP growth in Poland was $2.0 \%$ and $0.8 \%$, respectively. By contrast, it was significantly higher in 2016-2018: $2.5 \%$ on average per year. 2019 saw a further acceleration of the total factor productivity dynamics to a level of $2.6 \%$. In 2019, Poland's situation was very good compared to other countries. With a TFP growth rate equal $2.6 \%$, Poland ranked second among the EU-11 countries (after Romania with TFP growth of 2.9). As can be seen, Poland's second place in the ranking witnessed throughout the 2010-2019 period was maintained also in 2019. 
As regards TFP contribution to economic growth, the numerical values relating to the period under study are partly distorted, inter alia, by the fact that positive TFP dynamics during recession means a negative impact of TFP on economic growth (example of Croatia in 2011). On the other hand, when there is a strong economic slowdown and the GDP growth rate is close to $0 \%$, a change of a few percent in total factor productivity translates into a several thousand percent TFP change reflected in economic growth. Nevertheless, certain trends and regularities can be determined on the basis of aggregated results for the whole period.

As indicated by the data presented in Table 11.3, the percentage contributions of TFP to economic growth in most countries (except Croatia, the Czech Republic and Bulgaria) ranged between $29 \%$ and $82 \%$ in $2010-2019$. This confirms a significant share of TFP in the economic growth of the analyzed countries in the past decade. In Poland, the TFP contribution to GDP growth averaged 42\% in 2010-2019.

\subsection{Empirical Study Results at Sector-specific Level}

Growth accounting at sector-specific level has been carried out taking into account data for Poland and seven other EU countries. The analysis period covers the 20102018 period, which results from the availability of statistics (sectoral statistics are published late, so that data for 2019 were missing at the time of writing this Report). The analysis concerns sectors of the economy ranked according to the NACE-2 classification (10 sectors, or, with manufacturing treated separately, 11 sectors).

Changes in total factor productivity in sectors are calculated according to formula (11.9), that is, on the basis of the same methodology used for the economy as a whole. The rate of economic growth is measured by the dynamics of gross value added (GDP at producer prices) in a given sector of the economy. In turn, the rate of increase in labor inputs is represented by employment dynamics based on the number of hours worked. As in the case of the nationwide analysis, we calculate the physical capital stock time series using the perpetual inventory method, assuming the initial capital-output ratio of 3 and the depreciation rate of 5\%. Calculations of this time series start as early as 2000 (as in the nationwide analysis) to minimize the impact of initial assumptions on capital stock estimates. We have assumed that the shares of labor and capital in income amount to 0.5 each. For simplification, we assume that all model parameters are the same for the individual sectors of the economy.

Table 11.4 shows the results of the growth accounting analysis by sector. The data contained in the table include both results averaged over the whole period (20102018) and detailed information in individual years. For Poland, a full set of results is 
presented, including the growth rate of labor inputs, physical capital, TFP and GDP, as well as the contribution of each input to economic growth, expressed in percentage points and percent. For the other countries, only the TFP and GDP growth rates and TFP percentage contribution to economic growth are shown. Average percentage contributions (labor, capital and TFP) have been calculated on the basis of the averaged growth rate of a given variable and the averaged GDP growth rate, and they are not an arithmetical average of values reported in successive years.

Comparing the TFP growth rate in individual sectors of the economy, no clear difference can be seen between service sectors and other industries, including production sectors of the economy. In Poland, in 2010-2018, the highest annual average TFP growth rate was reported in construction (4.4\%). It should be borne in mind, however, that the high rate of TFP growth for the sector may be a reliable metric, especially in the case of Poland. In construction vary many workers are employed in the grey economy and they are not registered as officially employed workforce. Therefore, if we look at the data contained in Table 11.4, it turns out that in the majority of years in the period under study employment was decreasing in construction, with a growth recorded in a few cases only, and a small one too. In contrast, the gross value added growth rate in construction exceeded the double-digit mark in some years. Consequently, the TFP estimates obtained are high, as they result from the residual calculation method. However, they should be interpreted cautiously, since the sector can hardly be expected to see a definite improvement in the performance of inputs.

In sectors G-I, covering typical service activities (wholesale and retail trade, transportation, accommodation and food service activities), the TFP growth rate in Poland was $1.9 \%$ on average in 2010-2018. It was similar in sectors B-E, i.e. in industry (1.7\%). However, several service sectors can be identified reporting a high TFP growth rate in Poland. These are: information and communication (TFP growth of $4.1 \%$ annually in 2010-2018); financial and insurance activities (5.2\%), and professional, scientific and technical activities, administrative and support service activities (3.5\%). On the other hand, there are also service sectors in Poland which are characterized by a very slow growth of total factor productivity, or even its decline. They include: real estate activities (0.4\%); public administration and defense, education, human health and social work activities (0.1); and arts, entertainment and recreation, other service activities, households and exterritorial organizations (-1.0\%). As can be seen, data on Poland show that service sectors did not record a systematically lower or higher rate of TFP growth compared with other sectors of the economy.

By benchmarking Poland against the other countries listed in Table 11.4 (both from Central and Eastern Europe and from Western Europe) in terms of TFP dynamics in service sectors, one regularity can be identified. In the other countries (partly 
except Slovakia and, to a lesser extent, Germany), the TFP growth rate was, in general, low - this applies also to those service sectors in which Poland showed satisfactory results in terms of changes in total factor productivity (i.e., sectors J, K and M-N).

The growth accounting study conducted with the use of sectoral data has produced interesting results when it comes to the development of total factor productivity in individual sectors. It should provide a starting point for further, more in-depth studies on the issue. TFP change estimates are of major epistemic as well as practical significance, as they indicate to economic policymakers in which sectors high performance dynamics and a fast output growth, and, consequently, improvement of competitiveness can be achieved.

Table 11.4. Economic growth account by sector

\begin{tabular}{|c|c|c|c|c|c|c|c|c|c|c|c|}
\hline Country & Variable & Average & 2010 & 2011 & 2012 & 2013 & 2014 & 2015 & 2016 & 2017 & 2018 \\
\hline \multicolumn{12}{|c|}{ A: agriculture, forestry, hunting and fishing } \\
\hline \multirow{3}{*}{$\begin{array}{l}\text { Czech } \\
\text { Republic }\end{array}$} & TFP & -1.1 & -15.6 & -1.1 & 2.9 & -5.9 & 6.0 & 3.9 & 2.7 & -5.3 & 2.5 \\
\hline & GDP & 0.7 & -16.1 & 1.9 & 4.1 & -2.4 & 8.1 & 5.5 & 3.4 & -3.0 & 4.9 \\
\hline & TFP contribution (\%)* & -154.7 & 96.9 & -57.8 & 69.8 & 244.4 & 74.4 & 70.1 & 78.9 & 175.1 & 50.8 \\
\hline \multirow[t]{3}{*}{ France } & TFP & 0.1 & -4.0 & 4.0 & -9.4 & -2.7 & 14.4 & 0.1 & -12.9 & 9.5 & 2.3 \\
\hline & GDP & 0.6 & -3.4 & 4.0 & -8.4 & -1.9 & 14.7 & 0.1 & -12.4 & 9.1 & 3.4 \\
\hline & TFP contribution (\%)* & 25.6 & 116.4 & 99.9 & 111.6 & 143.0 & 98.0 & 67.7 & 104.2 & 104.8 & 67.9 \\
\hline \multirow[t]{3}{*}{ Germany } & TFP & -3.0 & -13.0 & -6.4 & 1.9 & 1.9 & 9.0 & -14.5 & -1.7 & -2.4 & -1.5 \\
\hline & GDP & -2.2 & -11.5 & -4.5 & 2.9 & 2.5 & 9.7 & -13.6 & -1.7 & -2.7 & -1.3 \\
\hline & TFP contribution (\%)* & 131.5 & 112.6 & 141.3 & 64.1 & 74.5 & 92.8 & 106.3 & 97.8 & 87.4 & 114.3 \\
\hline \multirow[t]{3}{*}{ Hungary } & TFP & 0.8 & -23.4 & 15.7 & -25.2 & 15.7 & 13.7 & 0.1 & 10.0 & -5.9 & 6.3 \\
\hline & GDP & 1.3 & -22.3 & 16.2 & -21.6 & 14.4 & 14.9 & -0.2 & 12.6 & -6.7 & 4.8 \\
\hline & TFP contribution (\%)* & 58.0 & 105.0 & 96.9 & 116.4 & 109.2 & 92.0 & -45.7 & 79.7 & 88.6 & 130.7 \\
\hline \multirow[t]{3}{*}{ Italy } & TFP & 0.1 & 0.9 & 3.5 & -0.8 & 0.8 & -3.5 & 4.0 & -1.2 & -2.8 & 0.3 \\
\hline & GDP & 0.1 & 0.7 & 2.3 & -1.9 & 1.0 & -2.3 & 4.7 & -0.1 & -3.9 & 0.7 \\
\hline & TFP contribution (\%)* & 99.3 & 131.3 & 153.5 & 42.8 & 80.8 & 151.2 & 84.0 & 1222.5 & 70.8 & 36.7 \\
\hline \multirow[t]{9}{*}{ Poland } & TFP & -2.8 & -5.7 & 0.3 & -1.0 & 8.6 & -0.2 & -12.0 & 3.7 & 2.6 & -11.3 \\
\hline & GDP & -2.2 & -6.8 & 2.1 & -9.5 & 9.1 & 0.7 & -8.5 & 3.0 & 2.5 & -12.7 \\
\hline & TFP contribution (\%)* & 124.6 & 83.7 & 12.0 & 116.3 & 94.9 & -31.4 & 141.3 & 123.5 & 105.4 & 88.9 \\
\hline & $\mathrm{L}$ & -2.9 & -5.9 & 0.3 & -0.9 & -3.3 & -1.7 & 2.9 & -6.7 & -4.4 & -6.3 \\
\hline & K & 4.0 & 3.7 & 3.4 & 4.0 & 4.2 & 3.5 & 4.1 & 5.3 & 4.1 & 3.5 \\
\hline & L contribution (pp) & -1.4 & -3.0 & 0.2 & -0.5 & -1.7 & -0.9 & 1.5 & -3.4 & -2.2 & -3.2 \\
\hline & K contribution (pp) & 2.0 & 1.8 & 1.7 & 2.0 & 2.1 & 1.8 & 2.1 & 2.6 & 2.1 & 1.7 \\
\hline & L contribution (\%)* & 64.7 & 43.4 & 7.1 & 4.7 & -18.1 & -121.4 & -17.1 & -111.7 & -88.0 & 24.8 \\
\hline & K contribution $(\%)^{*}$ & -89.3 & -27.1 & 80.9 & -21.0 & 23.3 & 252.8 & -24.3 & 88.2 & 82.6 & -13.7 \\
\hline \multirow[t]{3}{*}{ Slovakia } & TFP & 4.7 & -18.4 & 25.2 & 1.1 & 22.3 & 25.8 & -16.8 & 7.9 & -11.3 & 6.4 \\
\hline & GDP & 6.5 & -18.6 & 27.9 & 2.5 & 26.4 & 27.1 & -14.9 & 9.8 & -10.4 & 8.9 \\
\hline & TFP contribution (\%)* & 71.6 & 99.1 & 90.3 & 42.3 & 84.3 & 95.3 & 113.0 & 80.6 & 109.0 & 71.7 \\
\hline \multirow[t]{3}{*}{ Spain } & TFP & 2.2 & 2.1 & 5.3 & -8.2 & 14.9 & -1.2 & 4.7 & 2.4 & -5.1 & 4.7 \\
\hline & GDP & 2.6 & 2.6 & 4.9 & -9.4 & 13.9 & -1.3 & 4.7 & 4.8 & -3.0 & 5.9 \\
\hline & TFP contribution (\%)* & 84.7 & 78.9 & 109.0 & 87.1 & 107.0 & 92.2 & 99.2 & 50.2 & 171.1 & 80.3 \\
\hline
\end{tabular}




\begin{tabular}{|c|c|c|c|c|c|c|c|c|c|c|c|}
\hline Country & Variable & Average & 2010 & 2011 & 2012 & 2013 & 2014 & 2015 & 2016 & 2017 & 2018 \\
\hline \multicolumn{12}{|c|}{ B-E: industry (without construction) } \\
\hline \multirow{3}{*}{$\begin{array}{l}\text { Czech } \\
\text { Republic }\end{array}$} & TFP & 0.6 & 4.5 & 3.4 & -4.7 & -6.0 & 2.7 & 1.2 & -1.2 & 6.7 & -1.0 \\
\hline & GDP & 3.0 & 6.4 & 6.6 & -2.8 & -4.5 & 5.1 & 4.1 & 1.9 & 9.0 & 1.0 \\
\hline & TFP contribution (\%)* & 20.7 & 69.8 & 51.6 & 168.4 & 133.6 & 52.0 & 30.3 & -62.6 & 74.8 & -103.7 \\
\hline \multirow[t]{3}{*}{ France } & TFP & 0.5 & 2.1 & 1.7 & 0.1 & 0.7 & -0.2 & -0.1 & -0.3 & 0.8 & -0.6 \\
\hline & GDP & 0.9 & 1.9 & 2.8 & 0.8 & 0.7 & 0.5 & 0.4 & 0.3 & 0.8 & 0.1 \\
\hline & TFP contribution (\%)* & 50.4 & 110.5 & 59.3 & 14.8 & 94.3 & -30.4 & -13.5 & -114.1 & 98.2 & -594.1 \\
\hline \multirow[t]{3}{*}{ Germany } & TFP & 2.7 & 14.6 & 3.2 & -0.5 & -1.4 & 3.1 & 0.3 & 3.6 & 2.1 & -0.4 \\
\hline & GDP & 4.0 & 16.2 & 5.3 & 0.1 & -0.4 & 4.5 & 1.3 & 4.3 & 3.2 & 1.3 \\
\hline & TFP contribution (\%)* & 68.9 & 90.0 & 59.7 & -459.6 & 347.2 & 68.6 & 20.2 & 84.6 & 67.2 & -27.1 \\
\hline \multirow[t]{3}{*}{ Hungary } & TFP & 0.2 & 6.5 & -1.1 & -5.1 & -2.3 & 3.3 & 6.4 & -1.8 & -0.5 & -3.5 \\
\hline & GDP & 2.6 & 7.9 & -0.4 & -1.8 & -2.3 & 6.3 & 7.9 & 1.8 & 3.2 & 0.5 \\
\hline & TFP contribution (\%)* & 8.7 & 82.6 & 274.0 & 281.0 & 98.7 & 51.9 & 81.4 & -99.8 & -14.2 & -708.7 \\
\hline \multirow[t]{3}{*}{ Italy } & TFP & 1.3 & 7.5 & 0.7 & -2.1 & -0.9 & -0.3 & 1.0 & 2.1 & 2.9 & 0.8 \\
\hline & GDP & 1.4 & 6.9 & 1.2 & -3.5 & -2.0 & -0.7 & 1.2 & 3.2 & 3.9 & 2.0 \\
\hline & TFP contribution (\%)* & 95.6 & 108.0 & 54.8 & 59.5 & 45.1 & 39.7 & 87.5 & 66.0 & 73.9 & 38.6 \\
\hline \multirow[t]{9}{*}{ Poland } & TFP & 1.7 & 8.6 & 5.4 & 0.9 & -2.4 & 1.2 & 0.4 & -1.0 & -0.6 & 2.8 \\
\hline & GDP & 4.4 & 8.4 & 7.9 & 2.8 & 0.9 & 4.5 & 3.8 & 3.9 & 2.5 & 4.6 \\
\hline & TFP contribution (\%)* & 38.7 & 101.8 & 68.2 & 31.3 & -267.2 & 27.7 & 9.4 & -26.4 & -22.7 & 60.4 \\
\hline & L & 0.7 & -5.3 & 0.8 & -0.8 & 2.4 & 2.4 & 1.8 & 4.0 & 1.7 & -0.5 \\
\hline & $\mathrm{K}$ & 4.6 & 5.0 & 4.2 & 4.6 & 4.2 & 4.1 & 5.1 & 5.9 & 4.4 & 4.1 \\
\hline & L contribution (pp) & 0.4 & -2.7 & 0.4 & -0.4 & 1.2 & 1.2 & 0.9 & 2.0 & 0.9 & -0.3 \\
\hline & K contribution (pp) & 2.3 & 2.5 & 2.1 & 2.3 & 2.1 & 2.1 & 2.5 & 2.9 & 2.2 & 2.1 \\
\hline & L contribution $(\%)^{*}$ & 8.3 & -31.5 & 5.1 & -14.3 & 133.3 & 26.7 & 23.7 & 51.3 & 34.0 & -5.4 \\
\hline & K contribution $(\%)^{*}$ & 53.1 & 29.7 & 26.7 & 83.0 & 233.8 & 45.6 & 66.9 & 75.1 & 88.7 & 45.0 \\
\hline \multirow[t]{3}{*}{ Slovakia } & TFP & 4.3 & 18.7 & 1.8 & -2.5 & -3.8 & 14.2 & 5.7 & -4.5 & -1.9 & 10.6 \\
\hline & GDP & 6.8 & 20.6 & 5.1 & 0.4 & -2.4 & 16.4 & 8.3 & -1.2 & 0.8 & 13.1 \\
\hline & TFP contribution (\%)* & 62.7 & 90.6 & 35.3 & -624.6 & 158.1 & 86.6 & 69.1 & 375.2 & -243.0 & 81.0 \\
\hline \multirow[t]{3}{*}{ Spain } & TFP & 0.3 & 4.0 & 0.4 & -2.0 & -2.3 & 1.0 & 1.3 & 1.6 & 1.0 & -2.0 \\
\hline & GDP & 0.5 & 3.7 & -0.8 & -5.3 & -4.0 & 1.3 & 3.0 & 4.1 & 3.1 & -0.4 \\
\hline & TFP contribution (\%)* & 61.4 & 108.7 & -49.8 & 37.9 & 58.5 & 73.9 & 43.8 & 38.6 & 31.8 & 505.5 \\
\hline \multicolumn{12}{|c|}{ C: manufacturing } \\
\hline \multirow{3}{*}{$\begin{array}{l}\text { Czech } \\
\text { Republic }\end{array}$} & TFP & 2.3 & 9.7 & 7.5 & -4.8 & -4.1 & 3.9 & 2.0 & -0.1 & 7.7 & -0.9 \\
\hline & GDP & 4.7 & 11.3 & 10.1 & -3.2 & -2.7 & 6.2 & 5.2 & 3.5 & 10.5 & 1.6 \\
\hline & TFP contribution (\%)* & 49.1 & 85.7 & 73.8 & 149.3 & 152.7 & 62.6 & 38.9 & -3.6 & 73.6 & -54.6 \\
\hline \multirow[t]{3}{*}{ France } & TFP & 1.0 & 3.1 & 3.2 & -0.5 & 0.2 & 1.1 & 0.6 & 0.4 & 1.5 & -0.4 \\
\hline & GDP & 1.2 & 2.4 & 4.0 & -0.2 & -0.1 & 1.6 & 0.7 & 0.9 & 1.3 & 0.1 \\
\hline & TFP contribution (\%)* & 85.3 & 129.0 & 80.4 & 266.0 & -186.6 & 71.8 & 81.0 & 43.6 & 113.6 & -420.3 \\
\hline \multirow[t]{3}{*}{ Germany } & TFP & 3.3 & 17.6 & 6.2 & -2.3 & -1.0 & 3.6 & -0.1 & 3.5 & 2.1 & -0.1 \\
\hline & GDP & 4.5 & 19.1 & 8.3 & -1.8 & -0.1 & 5.0 & 0.9 & 4.1 & 3.1 & 1.5 \\
\hline & TFP contribution (\%)* & 73.5 & 92.2 & 75.2 & 127.5 & 1013.8 & 71.9 & -8.2 & 85.4 & 66.6 & -9.4 \\
\hline \multirow[t]{3}{*}{ Hungary } & TFP & 0.7 & 9.4 & -0.4 & -4.4 & -2.7 & 3.9 & 6.7 & -3.7 & 0.3 & -3.3 \\
\hline & GDP & 3.2 & 10.4 & 0.6 & -1.3 & -2.1 & 7.1 & 8.7 & 0.3 & 4.3 & 0.7 \\
\hline & TFP contribution (\%)* & 20.4 & 90.5 & -60.0 & 341.3 & 126.9 & 54.3 & 77.2 & -1227.2 & 6.7 & -467.6 \\
\hline \multirow[t]{3}{*}{ Italy } & TFP & 1.9 & 10.3 & 0.9 & -2.3 & -0.2 & 0.7 & 2.3 & 1.8 & 2.6 & 0.8 \\
\hline & GDP & 1.9 & 9.4 & 1.6 & -4.0 & -1.3 & 0.2 & 2.5 & 3.1 & 3.8 & 2.2 \\
\hline & TFP contribution (\%)* & 96.4 & 109.2 & 58.4 & 58.4 & 18.9 & 367.6 & 91.9 & 59.7 & 67.5 & 36.5 \\
\hline
\end{tabular}




\begin{tabular}{|c|c|c|c|c|c|c|c|c|c|c|c|}
\hline Country & Variable & Average & 2010 & 2011 & 2012 & 2013 & 2014 & 2015 & 2016 & 2017 & 2018 \\
\hline \multirow[t]{9}{*}{ Poland } & TFP & 2.6 & 9.4 & 6.0 & 1.9 & -2.5 & 5.0 & 3.2 & -0.7 & -2.0 & 2.7 \\
\hline & GDP & 5.3 & 8.8 & 7.9 & 3.2 & 0.4 & 7.9 & 7.0 & 4.5 & 2.4 & 5.4 \\
\hline & TFP contribution $(\%)^{*}$ & 48.6 & 107.2 & 76.5 & 59.0 & -625.8 & 62.8 & 46.3 & -15.4 & -81.7 & 49.3 \\
\hline & $\mathrm{L}$ & 1.1 & -5.9 & 0.5 & -1.2 & 2.4 & 2.4 & 2.9 & 5.1 & 3.4 & 0.3 \\
\hline & K & 4.3 & 4.6 & 3.2 & 3.8 & 3.4 & 3.5 & 4.6 & 5.3 & 5.3 & 5.2 \\
\hline & L contribution (pp) & 0.6 & -3.0 & 0.3 & -0.6 & 1.2 & 1.2 & 1.5 & 2.6 & 1.7 & 0.2 \\
\hline & K contribution (pp) & 2.2 & 2.3 & 1.6 & 1.9 & 1.7 & 1.7 & 2.3 & 2.6 & 2.7 & 2.6 \\
\hline & L contribution $(\%)^{*}$ & 10.4 & -33.5 & 3.2 & -18.8 & 300.0 & 15.2 & 20.7 & 56.7 & 70.8 & 2.8 \\
\hline & K contribution (\%)* & 41.0 & 26.3 & 20.4 & 59.8 & 425.8 & 22.0 & 33.0 & 58.8 & 110.8 & 47.9 \\
\hline \multirow[t]{3}{*}{ Slovakia } & TFP & 6.3 & 27.5 & 0.7 & -2.0 & -2.5 & 17.1 & 9.3 & -4.3 & -1.9 & 13.2 \\
\hline & GDP & 9.0 & 29.0 & 3.8 & 1.1 & -1.5 & 19.6 & 11.9 & -0.8 & 1.3 & 16.6 \\
\hline & TFP contribution (\%)* & 70.4 & 94.8 & 17.7 & -182.1 & 165.2 & 87.2 & 78.0 & 533.2 & -147.7 & 79.4 \\
\hline \multirow[t]{3}{*}{ Spain } & TFP & 1.4 & 2.0 & 1.0 & -1.0 & 2.0 & 3.0 & 3.6 & 0.1 & 2.8 & -0.9 \\
\hline & GDP & 0.7 & -0.3 & -1.6 & -5.8 & -1.0 & 2.1 & 4.6 & 2.3 & 4.9 & 0.7 \\
\hline & TFP contribution (\%)* & 211.2 & -675.1 & -59.6 & 17.7 & -196.9 & 143.7 & 79.2 & 2.2 & 56.2 & -131.3 \\
\hline \multicolumn{12}{|c|}{ F: construction } \\
\hline \multirow{3}{*}{$\begin{array}{l}\text { Czech } \\
\text { Republic }\end{array}$} & TFP & 0.3 & 2.7 & -5.6 & -1.8 & 2.9 & 3.8 & 4.5 & -3.4 & -3.8 & 3.4 \\
\hline & GDP & -0.1 & 4.0 & -6.7 & -3.1 & 1.3 & 2.0 & 3.9 & -3.7 & -2.8 & 4.1 \\
\hline & TFP contribution (\%)* & -274.2 & 68.1 & 83.5 & 58.4 & 223.7 & 191.6 & 115.7 & 92.7 & 135.3 & 82.6 \\
\hline \multirow[t]{3}{*}{ France } & TFP & 0.4 & -0.7 & -1.3 & -3.8 & 2.4 & -1.2 & 1.6 & 1.3 & 4.5 & 1.1 \\
\hline & GDP & -1.1 & -2.5 & -1.9 & -5.1 & 0.5 & -2.7 & -0.6 & -1.0 & 3.1 & 0.1 \\
\hline & TFP contribution (\%)* & -38.5 & 29.7 & 68.5 & 74.3 & 477.0 & 42.9 & -265.7 & -132.5 & 144.9 & 1082.6 \\
\hline \multirow[t]{3}{*}{ Germany } & TFP & 2.9 & 8.8 & 4.4 & 0.6 & -0.7 & 5.0 & 1.0 & 3.1 & 0.4 & 3.7 \\
\hline & GDP & 1.8 & 7.7 & 3.5 & -1.2 & -2.5 & 4.0 & -0.3 & 2.0 & -0.6 & 3.4 \\
\hline & TFP contribution $(\%)^{*}$ & 164.6 & 114.1 & 125.5 & -53.7 & 28.1 & 124.2 & -323.2 & 157.1 & -70.3 & 109.0 \\
\hline \multirow[t]{3}{*}{ Hungary } & TFP & 3.5 & -5.3 & 3.8 & -3.7 & 9.3 & 7.2 & 7.1 & -17.9 & 17.2 & 13.8 \\
\hline & GDP & 3.8 & -9.9 & 2.1 & -4.9 & 6.3 & 8.5 & 6.3 & -15.0 & 21.5 & 18.9 \\
\hline & TFP contribution (\%)* & 93.2 & 53.1 & 180.2 & 74.6 & 147.7 & 84.6 & 112.0 & 119.3 & 80.0 & 72.8 \\
\hline \multirow[t]{3}{*}{ Italy } & TFP & -1.1 & -3.5 & -1.9 & -4.1 & -0.8 & -4.5 & -0.9 & 1.5 & 0.7 & 3.2 \\
\hline & GDP & -3.6 & -5.7 & -3.6 & -9.4 & -7.1 & -7.7 & -2.4 & 0.9 & -0.2 & 2.4 \\
\hline & TFP contribution $(\%)^{*}$ & 31.2 & 61.8 & 53.0 & 43.2 & 10.6 & 58.9 & 36.1 & 164.3 & -358.5 & 133.7 \\
\hline \multirow[t]{9}{*}{ Poland } & TFP & 4.4 & 7.8 & 12.6 & -2.3 & -1.8 & 9.1 & 5.4 & -9.4 & 6.9 & 11.6 \\
\hline & GDP & 3.9 & 4.9 & 13.5 & -4.0 & -5.0 & 9.0 & 6.4 & -8.5 & 6.8 & 12.2 \\
\hline & TFP contribution (\%)* & 112.7 & 158.9 & 93.2 & 58.3 & 35.6 & 100.9 & 83.9 & 110.9 & 102.1 & 94.8 \\
\hline & L & -1.4 & -5.5 & 1.6 & -3.3 & -6.1 & -0.3 & 1.2 & 0.8 & -1.5 & 0.7 \\
\hline & $\mathrm{K}$ & 0.4 & -0.3 & 0.2 & 0.0 & -0.3 & 0.1 & 0.9 & 1.0 & 1.2 & 0.6 \\
\hline & L contribution (pp) & -0.7 & -2.8 & 0.8 & -1.7 & -3.1 & -0.2 & 0.6 & 0.4 & -0.8 & 0.4 \\
\hline & K contribution (pp) & 0.2 & -0.1 & 0.1 & 0.0 & -0.2 & 0.1 & 0.4 & 0.5 & 0.6 & 0.3 \\
\hline & L contribution $(\%)^{*}$ & -17.6 & -56.1 & 5.9 & 41.3 & 61.0 & -1.7 & 9.4 & -4.7 & -1.0 & 2.9 \\
\hline & K contribution (\%)* & 4.9 & -2.8 & 0.9 & 0.5 & 3.4 & 0.7 & 6.7 & -6.1 & 9.0 & 2.4 \\
\hline \multirow[t]{3}{*}{ Slovakia } & TFP & 1.4 & -4.5 & 9.0 & 8.4 & -11.7 & 8.1 & 1.3 & -2.0 & 8.7 & -4.1 \\
\hline & GDP & 0.7 & -6.1 & 6.1 & 6.0 & -14.9 & 7.5 & 0.7 & -0.5 & 10.1 & -2.2 \\
\hline & TFP contribution $(\%)^{*}$ & 194.3 & 74.5 & 146.7 & 140.2 & 78.6 & 107.8 & 183.6 & 405.7 & 86.0 & 187.2 \\
\hline \multirow[t]{3}{*}{ Spain } & TFP & -0.5 & -7.4 & -4.9 & 1.1 & -2.6 & 0.9 & 1.8 & 4.0 & 2.0 & 0.7 \\
\hline & GDP & -3.3 & -15.2 & -13.5 & -9.6 & -10.3 & -1.3 & 5.4 & 3.9 & 4.9 & 5.7 \\
\hline & TFP contribution (\%)* & 14.5 & 48.5 & 36.5 & -11.4 & 25.1 & -66.9 & 34.2 & 103.5 & 40.2 & 12.7 \\
\hline
\end{tabular}




\begin{tabular}{|c|c|c|c|c|c|c|c|c|c|c|c|}
\hline Country & Variable & Average & 2010 & 2011 & 2012 & 2013 & 2014 & 2015 & 2016 & 2017 & 2018 \\
\hline \multicolumn{12}{|c|}{ G-I: wholesale and retail trade, transportation, accommodation and food service activities } \\
\hline \multirow{3}{*}{$\begin{array}{l}\text { Czech } \\
\text { Republic }\end{array}$} & TFP & 1.7 & 2.3 & -1.0 & -0.1 & -1.1 & 2.8 & 7.5 & 0.0 & 1.4 & 3.6 \\
\hline & GDP & 2.8 & 4.1 & 0.7 & -0.1 & -0.6 & 3.4 & 7.7 & 1.9 & 3.2 & 5.1 \\
\hline & TFP contribution (\%)* & 61.1 & 56.2 & -143.5 & 53.7 & 180.9 & 83.6 & 97.8 & 1.1 & 42.5 & 70.9 \\
\hline \multirow[t]{3}{*}{ France } & TFP & 1.5 & 2.1 & 3.0 & 0.2 & 0.7 & 1.2 & 1.6 & 1.4 & 2.3 & 0.7 \\
\hline & GDP & 1.7 & 2.4 & 3.3 & 0.3 & 0.1 & 0.9 & 2.1 & 2.1 & 2.7 & 1.3 \\
\hline & TFP contribution (\%)* & 86.2 & 86.4 & 90.0 & 52.4 & 713.9 & 132.2 & 77.7 & 66.5 & 85.3 & 51.1 \\
\hline \multirow[t]{3}{*}{ Germany } & TFP & 1.0 & -2.0 & 3.2 & 2.7 & -0.7 & 1.3 & 1.4 & 0.7 & 2.0 & 0.7 \\
\hline & GDP & 1.6 & -2.0 & 4.2 & 2.8 & -0.8 & 1.8 & 1.9 & 1.4 & 2.9 & 1.8 \\
\hline & TFP contribution (\%)* & 66.1 & 100.5 & 76.1 & 95.9 & 89.1 & 74.8 & 71.2 & 52.5 & 68.6 & 37.4 \\
\hline \multirow[t]{3}{*}{ Hungary } & TFP & 2.4 & -0.3 & 0.8 & 0.7 & 4.2 & 2.8 & 0.6 & -0.8 & 4.2 & 9.1 \\
\hline & GDP & 3.8 & 0.5 & 2.0 & 1.0 & 4.8 & 5.0 & 3.0 & 2.3 & 5.4 & 10.2 \\
\hline & TFP contribution (\%)* & 62.8 & -51.2 & 39.8 & 66.9 & 87.7 & 56.6 & 21.5 & -33.5 & 78.4 & 89.3 \\
\hline \multirow[t]{3}{*}{ Italy } & TFP & 1.6 & 2.6 & 1.6 & -1.3 & 0.4 & 2.5 & 2.4 & 2.0 & 2.6 & 1.2 \\
\hline & GDP & 1.5 & 2.5 & 2.0 & -1.8 & -1.4 & 1.8 & 2.2 & 2.7 & 3.6 & 1.5 \\
\hline & TFP contribution (\%)* & 107.5 & 104.5 & 82.1 & 72.1 & -25.5 & 139.3 & 110.2 & 75.6 & 70.8 & 83.1 \\
\hline \multirow[t]{9}{*}{ Poland } & TFP & 1.9 & 2.9 & 0.7 & 2.2 & 0.1 & -2.5 & -0.1 & 1.3 & 7.2 & 5.0 \\
\hline & GDP & 3.3 & 3.7 & 2.0 & 4.1 & 1.0 & -0.2 & 2.0 & 4.0 & 8.1 & 5.4 \\
\hline & TFP contribution (\%)* & 55.8 & 79.0 & 36.9 & 53.8 & 8.2 & 1254.7 & -3.9 & 31.8 & 88.8 & 91.9 \\
\hline & L & 0.0 & -1.9 & -0.6 & -0.3 & -1.6 & 2.4 & 1.7 & 2.3 & -0.3 & -1.3 \\
\hline & $\mathrm{K}$ & 2.9 & 3.5 & 3.1 & 4.1 & 3.4 & 2.2 & 2.5 & 3.2 & 2.1 & 2.2 \\
\hline & L contribution (pp) & 0.0 & -1.0 & -0.3 & -0.2 & -0.8 & 1.2 & 0.9 & 1.2 & -0.2 & -0.7 \\
\hline & K contribution (pp) & 1.5 & 1.7 & 1.6 & 2.0 & 1.7 & 1.1 & 1.2 & 1.6 & 1.1 & 1.1 \\
\hline & L contribution $(\%)^{*}$ & 0.7 & -25.7 & -15.0 & -3.7 & -80.0 & -600.0 & 42.5 & 28.8 & -1.9 & -12.0 \\
\hline & K contribution $(\%)^{*}$ & 43.6 & 46.7 & 78.1 & 49.9 & 171.8 & -554.7 & 61.4 & 39.4 & 13.0 & 20.2 \\
\hline \multirow[t]{3}{*}{ Slovakia } & TFP & 0.5 & 3.1 & 0.7 & -0.7 & -5.3 & 2.7 & 1.3 & -6.3 & 2.1 & 6.3 \\
\hline & GDP & 1.7 & 3.5 & 1.9 & -0.3 & -5.6 & 4.4 & 3.2 & -3.8 & 3.9 & 7.8 \\
\hline & TFP contribution (\%)* & 27.3 & 89.8 & 38.2 & 225.5 & 94.4 & 61.7 & 41.7 & 164.9 & 54.8 & 80.5 \\
\hline \multirow[t]{3}{*}{ Spain } & TFP & 1.5 & 2.4 & 0.5 & -0.1 & -0.4 & 0.9 & 4.4 & 1.4 & 2.7 & 1.5 \\
\hline & GDP & 1.6 & 1.7 & 0.0 & -1.8 & -1.5 & 1.5 & 5.7 & 2.9 & 3.5 & 2.4 \\
\hline & TFP contribution (\%)* & 92.3 & 142.4 & - & 4.4 & 26.5 & 56.9 & 77.8 & 47.9 & 77.1 & 60.7 \\
\hline \multicolumn{12}{|c|}{ J: information and communication } \\
\hline \multirow{3}{*}{$\begin{array}{l}\text { Czech } \\
\text { Republic }\end{array}$} & TFP & 1.8 & -1.3 & 2.1 & -4.7 & 0.9 & 5.0 & 8.3 & -2.4 & 2.2 & 5.7 \\
\hline & GDP & 4.5 & -0.3 & 1.9 & -2.4 & 3.3 & 8.5 & 9.7 & 3.6 & 6.0 & 9.8 \\
\hline & TFP contribution (\%)* & 39.5 & 446.9 & 109.7 & 193.9 & 26.1 & 58.7 & 85.8 & -65.5 & 37.0 & 58.2 \\
\hline \multirow[t]{3}{*}{ France } & TFP & 1.1 & 0.8 & 3.4 & 1.4 & -2.6 & 2.5 & 0.6 & -0.7 & 3.6 & 0.8 \\
\hline & GDP & 4.0 & 3.8 & 6.3 & 4.7 & -0.5 & 4.2 & 3.8 & 3.1 & 6.5 & 4.3 \\
\hline & TFP contribution (\%)* & 27.1 & 19.8 & 54.2 & 28.9 & 514.9 & 60.4 & 15.8 & -21.8 & 55.0 & 18.8 \\
\hline \multirow[t]{3}{*}{ Germany } & TFP & 2.0 & -0.9 & 9.9 & 1.9 & 4.0 & 3.3 & -0.6 & -0.1 & 0.2 & 0.0 \\
\hline & GDP & 4.1 & -0.7 & 11.8 & 4.0 & 5.8 & 5.5 & 1.3 & 2.8 & 3.5 & 3.1 \\
\hline & TFP contribution (\%)* & 47.4 & 131.9 & 83.9 & 47.0 & 68.4 & 60.1 & -43.5 & -3.9 & 5.2 & -1.3 \\
\hline \multirow[t]{3}{*}{ Hungary } & TFP & 1.3 & 0.9 & -0.4 & 1.3 & -1.2 & -0.8 & -1.6 & -0.9 & 7.6 & 7.0 \\
\hline & GDP & 4.8 & 0.9 & 4.0 & 1.6 & 3.3 & 4.6 & 1.2 & 4.9 & 11.3 & 11.1 \\
\hline & TFP contribution (\%)* & 27.9 & 104.9 & -9.7 & 83.1 & -37.7 & -16.6 & -129.2 & -18.7 & 67.1 & 63.0 \\
\hline \multirow[t]{3}{*}{ Italy } & TFP & -1.2 & 1.9 & -1.7 & -5.3 & -1.9 & -0.2 & -1.4 & 1.2 & 1.7 & -5.0 \\
\hline & GDP & 0.5 & 2.0 & -0.9 & -4.5 & -0.7 & 0.1 & 1.2 & 4.8 & 4.3 & -2.2 \\
\hline & TFP contribution (\%)* & -257.9 & 95.1 & 185.3 & 117.0 & 276.1 & -181.2 & -120.0 & 26.0 & 40.7 & 226.7 \\
\hline
\end{tabular}




\begin{tabular}{|c|c|c|c|c|c|c|c|c|c|c|c|}
\hline Country & Variable & Average & 2010 & 2011 & 2012 & 2013 & 2014 & 2015 & 2016 & 2017 & 2018 \\
\hline \multirow[t]{9}{*}{ Poland } & TFP & 4.1 & 1.9 & 4.9 & 4.3 & 0.6 & 0.8 & 3.8 & 12.0 & 5.1 & 3.9 \\
\hline & GDP & 7.5 & 1.1 & 6.0 & 9.9 & 4.6 & 6.6 & 8.1 & 12.8 & 8.9 & 9.3 \\
\hline & TFP contribution $(\%)^{*}$ & 55.4 & 174.7 & 81.3 & 43.1 & 13.5 & 12.7 & 46.8 & 93.6 & 56.9 & 42.1 \\
\hline & $\mathrm{L}$ & 3.0 & -6.5 & -1.4 & 7.2 & 4.4 & 7.8 & 4.9 & -1.3 & 5.3 & 6.5 \\
\hline & K & 3.7 & 4.9 & 3.6 & 4.1 & 3.6 & 3.7 & 3.7 & 2.9 & 2.4 & 4.3 \\
\hline & L contribution (pp) & 1.5 & -3.3 & -0.7 & 3.6 & 2.2 & 3.9 & 2.5 & -0.7 & 2.7 & 3.3 \\
\hline & K contribution (pp) & 1.8 & 2.4 & 1.8 & 2.0 & 1.8 & 1.9 & 1.9 & 1.5 & 1.2 & 2.1 \\
\hline & L contribution $(\%)^{*}$ & 20.0 & -295.5 & -11.7 & 36.4 & 47.8 & 59.1 & 30.2 & -5.1 & 29.8 & 34.9 \\
\hline & K contribution (\%)* & 24.6 & 220.8 & 30.4 & 20.5 & 38.6 & 28.2 & 23.0 & 11.5 & 13.3 & 23.0 \\
\hline \multirow[t]{3}{*}{ Slovakia } & TFP & 0.7 & 2.2 & -8.9 & 16.4 & -8.2 & -7.4 & 3.5 & 8.0 & 2.6 & -2.5 \\
\hline & GDP & 3.0 & 3.1 & 0.3 & 16.4 & -5.7 & -6.3 & 3.9 & 10.8 & 4.8 & 0.0 \\
\hline & TFP contribution (\%)* & 21.6 & 71.0 & -2957.7 & 100.0 & 143.2 & 116.8 & 90.9 & 74.5 & 54.4 & - \\
\hline \multirow[t]{3}{*}{ Spain } & TFP & 1.2 & 2.9 & -4.5 & 1.4 & 1.7 & 5.3 & 1.3 & -0.3 & 1.8 & 1.2 \\
\hline & GDP & 3.8 & 2.9 & -1.2 & 1.0 & 2.6 & 6.4 & 5.5 & 4.4 & 7.7 & 5.0 \\
\hline & TFP contribution $(\%)^{*}$ & 31.6 & 99.7 & 372.1 & 141.7 & 64.7 & 82.4 & 24.1 & -6.5 & 23.6 & 23.5 \\
\hline \multicolumn{12}{|c|}{$K:$ financial and insurance activities } \\
\hline \multirow{3}{*}{$\begin{array}{l}\text { Czech } \\
\text { Republic }\end{array}$} & TFP & 2.6 & 0.3 & 0.4 & -2.6 & 7.9 & -2.3 & 7.0 & 5.3 & 6.9 & 0.4 \\
\hline & GDP & 3.6 & 0.3 & 2.7 & 0.5 & 9.2 & -1.4 & 5.3 & 6.4 & 6.5 & 3.3 \\
\hline & TFP contribution (\%)* & 71.0 & 98.4 & 15.5 & -518.1 & 86.1 & 167.7 & 132.2 & 83.0 & 106.2 & 11.6 \\
\hline \multirow[t]{3}{*}{ France } & TFP & 0.8 & -0.4 & 5.3 & 1.0 & -0.6 & 1.2 & -1.3 & -1.4 & -1.3 & 4.8 \\
\hline & GDP & 1.8 & 0.4 & 6.6 & 2.3 & 0.0 & 1.3 & 0.2 & -0.3 & -0.4 & 6.2 \\
\hline & TFP contribution (\%)* & 43.4 & -111.6 & 81.0 & 43.2 & - & 88.5 & -656.3 & 475.3 & 337.0 & 76.6 \\
\hline \multirow[t]{3}{*}{ Germany } & TFP & 2.2 & 5.4 & 4.0 & 0.2 & 7.6 & -3.8 & 0.1 & -2.0 & 6.2 & 1.7 \\
\hline & GDP & 0.5 & 3.6 & 2.0 & -1.8 & 6.2 & -5.1 & -0.9 & -3.5 & 3.8 & -0.1 \\
\hline & TFP contribution (\%)* & 461.8 & 148.7 & 198.7 & -10.3 & 122.0 & 73.8 & -10.0 & 55.8 & 164.2 & -1709.0 \\
\hline \multirow[t]{3}{*}{ Hungary } & TFP & 0.5 & -5.7 & -1.9 & -6.6 & 2.1 & -0.3 & 4.1 & 2.0 & 3.8 & 6.7 \\
\hline & GDP & -0.7 & -5.9 & -3.1 & -3.5 & -3.6 & -1.6 & 0.7 & 1.2 & 5.6 & 4.1 \\
\hline & TFP contribution (\%)* & -68.4 & 97.1 & 61.8 & 187.7 & -57.6 & 18.6 & 586.9 & 168.5 & 67.3 & 163.6 \\
\hline \multirow[t]{3}{*}{ Italy } & TFP & 1.5 & 6.4 & 3.4 & 3.5 & -0.2 & 1.2 & -0.4 & 0.5 & 0.7 & -2.0 \\
\hline & GDP & -0.1 & 4.6 & 1.5 & 1.7 & -2.9 & -0.6 & -1.1 & -0.6 & -0.7 & -2.4 \\
\hline & TFP contribution (\%)* & -2616.1 & 139.8 & 226.2 & 206.4 & 7.1 & -201.4 & 37.9 & -76.1 & -104.5 & 84.5 \\
\hline \multirow[t]{9}{*}{ Poland } & TFP & 5.2 & -0.6 & 6.1 & -3.2 & 16.0 & 9.6 & 11.3 & 10.5 & -2.9 & 10.4 \\
\hline & GDP & 6.1 & -2.8 & 8.3 & -9.9 & 14.4 & 9.6 & 14.7 & 9.5 & -2.1 & 13.2 \\
\hline & TFP contribution (\%)* & 85.9 & 22.0 & 73.6 & 132.8 & 110.9 & 99.6 & 76.9 & 110.2 & 139.1 & 78.9 \\
\hline & L & 0.8 & -5.7 & 4.2 & 6.2 & -3.5 & -0.6 & 5.5 & -2.8 & 0.7 & 3.2 \\
\hline & $\mathrm{K}$ & 0.9 & 1.3 & 0.2 & 0.3 & 0.4 & 0.7 & 1.3 & 0.9 & 0.9 & 2.4 \\
\hline & L contribution (pp) & 0.4 & -2.9 & 2.1 & 3.1 & -1.8 & -0.3 & 2.8 & -1.4 & 0.4 & 1.6 \\
\hline & K contribution (pp) & 0.5 & 0.7 & 0.1 & 0.2 & 0.2 & 0.3 & 0.6 & 0.4 & 0.5 & 1.2 \\
\hline & L contribution $(\%)^{*}$ & 6.6 & 101.8 & 25.3 & -31.3 & -12.2 & -3.1 & 18.7 & -14.7 & -16.7 & 12.1 \\
\hline & K contribution (\%)* & 7.6 & -23.8 & 1.1 & -1.5 & 1.3 & 3.5 & 4.4 & 4.6 & -22.4 & 9.0 \\
\hline \multirow[t]{3}{*}{ Slovakia } & TFP & 3.6 & 10.9 & 6.7 & -3.6 & 5.1 & 10.6 & -0.9 & -1.1 & -2.7 & 7.2 \\
\hline & GDP & 4.5 & 8.8 & 6.5 & -0.7 & 5.7 & 12.3 & 1.5 & 0.1 & -3.2 & 9.1 \\
\hline & TFP contribution (\%)* & 80.5 & 123.9 & 103.0 & 512.9 & 89.1 & 86.4 & -57.6 & -1135.1 & 83.7 & 79.6 \\
\hline \multirow[t]{3}{*}{ Spain } & TFP & -2.8 & -4.9 & -3.9 & -7.8 & -6.3 & -2.9 & -5.7 & -0.9 & 0.7 & 7.0 \\
\hline & GDP & -3.0 & -3.9 & -4.4 & -6.7 & -8.2 & -4.1 & -7.5 & 0.4 & 0.5 & 6.7 \\
\hline & TFP contribution (\%)* & 91.3 & 124.6 & 89.0 & 117.0 & 77.4 & 71.5 & 75.4 & -232.9 & 135.6 & 104.1 \\
\hline
\end{tabular}




\begin{tabular}{|c|c|c|c|c|c|c|c|c|c|c|c|}
\hline Country & Variable & Average & 2010 & 2011 & 2012 & 2013 & 2014 & 2015 & 2016 & 2017 & 2018 \\
\hline \multicolumn{12}{|c|}{ L: real estate activities } \\
\hline \multirow{3}{*}{$\begin{array}{l}\text { Czech } \\
\text { Republic }\end{array}$} & TFP & 0.0 & -2.0 & 4.6 & -2.1 & 1.3 & 1.2 & 1.8 & -0.9 & -3.6 & -0.7 \\
\hline & GDP & 1.9 & 1.0 & 2.0 & 1.7 & 1.9 & 3.2 & 2.5 & 3.2 & 0.1 & 1.9 \\
\hline & TFP contribution (\%)* & -2.3 & -200.5 & 227.9 & -120.8 & 70.1 & 36.9 & 72.2 & -28.9 & -3589.2 & -37.1 \\
\hline \multirow[t]{3}{*}{ France } & TFP & -0.7 & -0.5 & -4.3 & -1.2 & -0.1 & 1.2 & -0.3 & -2.0 & -0.5 & 0.8 \\
\hline & GDP & 1.1 & 2.0 & -0.2 & 1.8 & 2.0 & 1.1 & 0.3 & 0.8 & 0.7 & 1.5 \\
\hline & TFP contribution (\%)* & -67.0 & -23.1 & 2131.7 & -64.1 & -3.0 & 108.4 & -94.3 & -254.6 & -64.3 & 54.7 \\
\hline \multirow[t]{3}{*}{ Germany } & TFP & -1.4 & -3.4 & 3.1 & -4.6 & 0.4 & -1.6 & -0.3 & -1.6 & -3.8 & -0.9 \\
\hline & GDP & 0.6 & -1.1 & 4.5 & -2.5 & 2.6 & 0.5 & 1.2 & 0.0 & -1.0 & 1.1 \\
\hline & TFP contribution (\%)* & -237.0 & 305.9 & 68.4 & 184.6 & 14.6 & -310.4 & -21.2 & - & 376.3 & -80.9 \\
\hline \multirow[t]{3}{*}{ Hungary } & TFP & 0.0 & -4.0 & 1.3 & -1.0 & 2.6 & 1.3 & -1.2 & 0.6 & -0.3 & 0.9 \\
\hline & GDP & 1.1 & -1.3 & 2.9 & -1.9 & 1.5 & 0.7 & -0.6 & 3.0 & 2.5 & 2.8 \\
\hline & TFP contribution (\%)* & 3.0 & 306.7 & 46.1 & 53.8 & 176.5 & 186.5 & 197.0 & 20.3 & -11.3 & 30.6 \\
\hline \multirow[t]{3}{*}{ Italy } & TFP & -0.5 & -5.1 & -0.5 & -0.6 & -0.6 & 1.5 & 1.4 & -2.0 & 1.7 & 0.1 \\
\hline & GDP & 0.6 & -1.4 & 1.9 & -0.4 & -0.8 & 0.7 & 2.1 & 0.1 & 1.3 & 2.0 \\
\hline & TFP contribution (\%)* & -74.4 & 360.7 & -5.3 & 153.5 & 77.3 & 208.3 & 68.3 & -1957.2 & 128.6 & 3.2 \\
\hline \multirow[t]{9}{*}{ Poland } & TFP & 0.4 & 0.3 & 2.1 & 3.8 & 0.6 & -3.8 & -10.4 & 8.4 & 3.2 & -0.4 \\
\hline & GDP & 2.5 & 6.7 & 4.2 & 0.2 & 0.7 & 5.1 & -2.8 & 7.4 & -0.9 & 1.7 \\
\hline & TFP contribution (\%)* & 16.6 & 4.0 & 48.9 & 1896.0 & 85.7 & -74.0 & 372.2 & 114.1 & -353.9 & -25.9 \\
\hline & L & -0.6 & 5.9 & -1.3 & -12.3 & -4.9 & 12.9 & 9.9 & -5.7 & -11.1 & 1.5 \\
\hline & $\mathrm{K}$ & 4.7 & 7.0 & 5.6 & 5.1 & 5.1 & 4.8 & 5.3 & 3.6 & 2.9 & 2.8 \\
\hline & L contribution (pp) & -0.3 & 3.0 & -0.7 & -6.2 & -2.5 & 6.5 & 5.0 & -2.9 & -5.6 & 0.8 \\
\hline & K contribution (pp) & 2.3 & 3.5 & 2.8 & 2.6 & 2.6 & 2.4 & 2.7 & 1.8 & 1.5 & 1.4 \\
\hline & L contribution $(\%)^{*}$ & -11.4 & 44.0 & -15.5 & -3075.0 & -350.0 & 126.5 & -176.8 & -38.5 & 616.7 & 44.1 \\
\hline & K contribution $(\%)^{*}$ & 94.8 & 52.0 & 66.6 & 1279.0 & 364.3 & 47.5 & -95.4 & 24.4 & -162.8 & 81.8 \\
\hline \multirow[t]{3}{*}{ Slovakia } & TFP & -1.8 & -1.0 & -2.8 & 2.7 & 22.9 & -28.6 & 0.1 & 7.3 & -0.6 & -6.2 \\
\hline & GDP & 2.0 & -2.0 & 2.2 & 6.0 & 20.9 & -28.5 & 1.6 & 14.0 & 5.2 & -1.7 \\
\hline & TFP contribution (\%)* & -92.1 & 552.0 & -126.6 & 44.2 & 109.5 & 100.4 & 4.8 & 52.4 & -12.1 & 363.8 \\
\hline \multirow[t]{3}{*}{ Spain } & TFP & -0.1 & 1.0 & 2.5 & 4.1 & 4.5 & -4.5 & -4.1 & -1.3 & -0.9 & -2.4 \\
\hline & GDP & 1.7 & 2.3 & 3.7 & 2.4 & 1.5 & 0.1 & -0.2 & 1.3 & 1.7 & 2.3 \\
\hline & TFP contribution (\%)* & -7.6 & 43.7 & 66.7 & 171.5 & 302.4 & -4506.5 & 2059.4 & -101.7 & -54.6 & -104.0 \\
\hline \multicolumn{12}{|c|}{ M-N: professional, scientific and technical activities; administrative and support service activities } \\
\hline \multirow{3}{*}{$\begin{array}{l}\text { Czech } \\
\text { Republic }\end{array}$} & TFP & 0.6 & -2.0 & 1.8 & -1.4 & 0.4 & -1.4 & 6.4 & 0.2 & 1.2 & 0.3 \\
\hline & GDP & 3.0 & -0.7 & 1.9 & 1.1 & 3.0 & 1.2 & 7.3 & 5.5 & 3.3 & 4.1 \\
\hline & TFP contribution (\%)* & 20.9 & 285.8 & 97.1 & -123.1 & 12.4 & -115.8 & 87.3 & 3.6 & 37.5 & 7.6 \\
\hline \multirow[t]{3}{*}{ France } & TFP & 0.4 & 1.8 & 0.4 & -1.1 & -0.5 & -0.3 & 0.2 & -0.4 & 1.6 & 2.0 \\
\hline & GDP & 2.5 & 3.9 & 3.5 & -0.1 & 0.4 & 1.3 & 1.7 & 2.6 & 4.4 & 4.4 \\
\hline & TFP contribution (\%)* & 16.3 & 45.4 & 10.5 & 1142.7 & -129.7 & -21.0 & 11.1 & -15.9 & 36.2 & 46.2 \\
\hline \multirow[t]{3}{*}{ Germany } & TFP & 0.6 & 0.5 & -0.1 & 0.5 & 0.5 & 1.3 & 0.4 & -0.1 & 1.4 & 0.6 \\
\hline & GDP & 2.4 & 3.6 & 2.5 & 1.5 & 1.3 & 2.9 & 2.1 & 1.9 & 3.7 & 2.2 \\
\hline & TFP contribution (\%)* & 23.0 & 13.8 & -2.3 & 30.5 & 38.8 & 43.5 & 20.5 & -2.9 & 36.9 & 26.5 \\
\hline \multirow[t]{3}{*}{ Hungary } & TFP & 2.3 & 1.0 & 1.7 & 7.0 & -3.3 & -8.8 & 2.3 & 2.6 & 6.8 & 11.3 \\
\hline & GDP & 5.5 & 2.4 & 3.0 & 0.4 & 4.1 & 5.1 & 7.0 & 6.1 & 9.8 & 11.6 \\
\hline & TFP contribution (\%)* & 41.7 & 41.7 & 55.0 & 1761.6 & -81.3 & -173.2 & 32.7 & 43.4 & 69.6 & 97.8 \\
\hline \multirow[t]{3}{*}{ Italy } & TFP & -0.8 & 0.1 & -2.2 & -3.6 & 0.7 & 0.0 & -0.3 & 0.5 & 0.2 & -2.3 \\
\hline & GDP & 0.1 & 1.5 & -0.9 & -4.0 & -0.3 & 0.5 & 0.9 & 1.5 & 1.8 & -0.1 \\
\hline & TFP contribution (\%)* & -778.0 & 7.6 & 244.4 & 89.2 & -217.4 & -9.3 & -28.5 & 30.6 & 9.8 & 2332.3 \\
\hline
\end{tabular}




\begin{tabular}{|c|c|c|c|c|c|c|c|c|c|c|c|}
\hline Country & Variable & Average & 2010 & 2011 & 2012 & 2013 & 2014 & 2015 & 2016 & 2017 & 2018 \\
\hline \multirow[t]{9}{*}{ Poland } & TFP & 3.5 & -2.4 & 2.1 & 3.3 & 3.6 & -0.4 & 9.2 & -2.4 & 10.0 & 8.0 \\
\hline & GDP & 5.6 & 0.4 & 4.9 & 4.9 & 3.9 & 4.4 & 10.3 & 1.2 & 12.4 & 7.7 \\
\hline & TFP contribution $(\%)^{*}$ & 62.1 & -595.2 & 43.0 & 66.4 & 93.3 & -8.3 & 89.5 & -199.0 & 80.7 & 104.4 \\
\hline & L & 2.4 & 4.5 & 4.8 & 1.9 & -0.6 & 8.3 & -0.4 & 4.2 & 2.2 & -3.7 \\
\hline & K & 1.9 & 1.1 & 0.8 & 1.4 & 1.1 & 1.2 & 2.6 & 3.0 & 2.6 & 3.0 \\
\hline & L contribution (pp) & 1.2 & 2.3 & 2.4 & 1.0 & -0.3 & 4.2 & -0.2 & 2.1 & 1.1 & -1.9 \\
\hline & K contribution (pp) & 0.9 & 0.5 & 0.4 & 0.7 & 0.6 & 0.6 & 1.3 & 1.5 & 1.3 & 1.5 \\
\hline & L contribution $(\%)^{*}$ & 21.2 & 562.5 & 49.0 & 19.4 & -7.7 & 94.3 & -1.9 & 175.0 & 8.9 & -24.0 \\
\hline & K contribution $(\%)^{*}$ & 16.7 & 132.7 & 8.1 & 14.2 & 14.4 & 14.0 & 12.4 & 124.0 & 10.5 & 19.6 \\
\hline \multirow[t]{3}{*}{ Slovakia } & TFP & 2.1 & 6.8 & -6.7 & 5.1 & 5.6 & 5.8 & 4.5 & -2.4 & 2.3 & -1.5 \\
\hline & GDP & 5.2 & 7.2 & -4.6 & 8.6 & 3.7 & 6.4 & 12.7 & 4.5 & 4.7 & 3.8 \\
\hline & TFP contribution (\%)* & 41.0 & 94.1 & 146.5 & 58.7 & 150.3 & 90.1 & 35.5 & -4.4 & 48.9 & -39.7 \\
\hline \multirow[t]{3}{*}{ Spain } & TFP & 1.7 & 0.6 & 3.3 & -1.7 & 0.5 & 3.1 & 2.7 & 1.4 & 3.5 & 1.8 \\
\hline & GDP & 3.0 & -0.2 & 2.7 & -3.3 & -0.3 & 6.0 & 7.2 & 4.6 & 5.4 & 4.9 \\
\hline & TFP contribution (\%)* & 56.9 & -320.0 & 122.7 & 51.0 & -176.7 & 52.1 & 38.1 & 29.9 & 64.7 & 37.2 \\
\hline \multicolumn{12}{|c|}{ O_Q: public administration and defense; education, human health and social work activities } \\
\hline \multirow{3}{*}{$\begin{array}{l}\text { Czech } \\
\text { Republic }\end{array}$} & TFP & -0.7 & -0.7 & -3.1 & 0.5 & -0.4 & -1.7 & -0.4 & -1.3 & -0.4 & 0.9 \\
\hline & GDP & 0.8 & 1.2 & -1.9 & 0.3 & 0.5 & 0.8 & 0.6 & 2.3 & 1.4 & 1.9 \\
\hline & TFP contribution (\%)* & -92.7 & -55.3 & 162.5 & 167.4 & -76.2 & -216.9 & -60.0 & -56.9 & -31.4 & 47.0 \\
\hline \multirow[t]{3}{*}{ France } & TFP & 0.7 & 0.0 & 0.9 & 1.3 & 0.9 & 0.3 & -0.1 & 0.8 & 1.4 & 1.0 \\
\hline & GDP & 1.0 & 0.9 & 1.4 & 1.4 & 1.1 & 1.0 & 0.3 & 1.1 & 0.9 & 0.9 \\
\hline & TFP contribution (\%)* & 73.2 & 3.0 & 62.0 & 95.6 & 84.1 & 28.8 & -26.8 & 68.7 & 157.8 & 116.4 \\
\hline \multirow[t]{3}{*}{ Germany } & TFP & 0.6 & -0.3 & 1.3 & -0.1 & -1.7 & -0.3 & 2.0 & 2.8 & 1.9 & -0.4 \\
\hline & GDP & 1.9 & 1.8 & 1.7 & 0.7 & -0.9 & 1.1 & 3.5 & 4.2 & 3.4 & 1.2 \\
\hline & TFP contribution $(\%)^{*}$ & 31.1 & -18.1 & 76.0 & -9.2 & 190.4 & -24.2 & 57.5 & 66.1 & 54.6 & -31.1 \\
\hline \multirow[t]{3}{*}{ Hungary } & TFP & -0.5 & -1.5 & 3.6 & 0.6 & 2.3 & -3.1 & -3.1 & -3.9 & 1.8 & -0.8 \\
\hline & GDP & 1.5 & 1.1 & 2.0 & 1.8 & 5.2 & 0.5 & 1.1 & 1.9 & -0.7 & 0.4 \\
\hline & TFP contribution (\%)* & -31.3 & -140.4 & 178.4 & 35.8 & 45.0 & -629.3 & -286.2 & -203.6 & -261.1 & -209.0 \\
\hline \multirow[t]{3}{*}{ Italy } & TFP & -0.1 & 0.6 & -0.4 & -1.1 & 0.0 & 0.7 & -0.2 & -0.8 & 0.3 & 0.3 \\
\hline & GDP & -0.6 & 0.3 & -0.3 & -2.3 & -0.9 & 0.4 & -0.8 & -1.0 & -0.5 & -0.2 \\
\hline & TFP contribution (\%)* & 11.1 & 210.6 & 119.4 & 46.6 & 5.4 & 168.5 & 19.5 & 85.0 & -59.3 & -147.4 \\
\hline \multirow[t]{9}{*}{ Poland } & TFP & 0.1 & -0.3 & 0.7 & -1.6 & -1.3 & 0.0 & 0.6 & 0.3 & 1.5 & 0.9 \\
\hline & GDP & 1.2 & -0.3 & 1.1 & 0.1 & 0.9 & 1.7 & 2.0 & 1.3 & 2.4 & 1.9 \\
\hline & TFP contribution (\%)* & 9.1 & 110.6 & 65.8 & -1567.4 & -40.5 & 1.4 & 31.9 & 25.5 & 64.4 & 48.2 \\
\hline & L & 1.0 & -0.2 & -0.7 & 1.3 & 3.0 & 1.9 & 1.4 & 0.2 & 1.3 & 0.7 \\
\hline & $\mathrm{K}$ & 1.3 & 0.3 & 1.5 & 2.0 & 1.3 & 1.5 & 1.3 & 1.7 & 0.4 & 1.3 \\
\hline & L contribution (pp) & 0.5 & -0.1 & -0.4 & 0.7 & 1.5 & 1.0 & 0.7 & 0.1 & 0.7 & 0.4 \\
\hline & K contribution $(p p)$ & 0.6 & 0.1 & 0.7 & 1.0 & 0.7 & 0.7 & 0.7 & 0.9 & 0.2 & 0.6 \\
\hline & L contribution (\%)* & 40.1 & 33.3 & -31.8 & 650.0 & 166.7 & 55.9 & 35.0 & 7.7 & 27.1 & 18.4 \\
\hline & K contribution (\%)* & 50.8 & -44.0 & 66.0 & 1017.4 & 73.8 & 42.7 & 33.1 & 66.8 & 8.5 & 33.4 \\
\hline \multirow[t]{3}{*}{ Slovakia } & TFP & -0.1 & 0.2 & -6.4 & -1.6 & 2.1 & -7.2 & 1.5 & 7.3 & 1.3 & 2.1 \\
\hline & GDP & 1.3 & 2.4 & -4.7 & -0.1 & 2.7 & -5.1 & 2.8 & 10.1 & 1.4 & 2.6 \\
\hline & TFP contribution (\%)* & -4.9 & 8.6 & 136.2 & 1572.5 & 78.7 & 140.6 & 51.8 & 72.6 & 93.4 & 81.5 \\
\hline \multirow[t]{3}{*}{ Spain } & TFP & 0.0 & -0.8 & -0.7 & -1.7 & 0.5 & -1.3 & 0.9 & 0.7 & 1.6 & 0.5 \\
\hline & GDP & 0.8 & 1.7 & 1.8 & -1.7 & 0.2 & -0.7 & 1.1 & 1.4 & 1.5 & 1.7 \\
\hline & TFP contribution $(\%)^{*}$ & -3.0 & -45.1 & -37.1 & 101.2 & 226.7 & 181.1 & 84.1 & 46.5 & 109.7 & 31.6 \\
\hline
\end{tabular}




\begin{tabular}{|c|c|c|c|c|c|c|c|c|c|c|c|}
\hline Country & Variable & Average & 2010 & 2011 & 2012 & 2013 & 2014 & 2015 & 2016 & 2017 & 2018 \\
\hline \multicolumn{12}{|c|}{ R-U: arts, entertainment and recreation; other service activities; households and exterritorial organizations. } \\
\hline \multirow{3}{*}{$\begin{array}{l}\text { Czech } \\
\text { Republic }\end{array}$} & TFP & 0.2 & -4.1 & 2.9 & -1.4 & -0.6 & -0.1 & 6.8 & 2.0 & -2.9 & -0.6 \\
\hline & GDP & 1.4 & -2.1 & 4.4 & -1.0 & -1.1 & 1.5 & 7.3 & 5.4 & -1.0 & -0.4 \\
\hline & TFP contribution (\%)* & 16.0 & 194.7 & 65.2 & 140.7 & 54.6 & -8.8 & 93.8 & 37.1 & 286.4 & 137.9 \\
\hline \multirow[t]{3}{*}{ France } & TFP & -0.4 & 1.3 & -2.7 & -0.7 & -0.6 & -1.1 & -2.1 & -0.1 & 1.3 & 1.0 \\
\hline & GDP & 0.2 & 2.9 & -1.6 & -0.3 & -0.1 & -0.2 & -1.1 & 0.1 & 1.0 & 0.7 \\
\hline & TFP contribution (\%)* & -261.4 & 43.4 & 165.7 & 234.7 & 587.1 & 564.5 & 190.8 & -64.0 & 129.1 & 146.3 \\
\hline \multirow[t]{3}{*}{ Germany } & TFP & 0.2 & -0.4 & 1.8 & 0.3 & -0.5 & -0.5 & 1.2 & -1.5 & 0.9 & 0.6 \\
\hline & GDP & -0.4 & -0.7 & 1.0 & -0.4 & -1.6 & -1.3 & 0.9 & -2.0 & 0.8 & 0.1 \\
\hline & TFP contribution (\%)* & -55.0 & 63.8 & 177.6 & -80.2 & 33.7 & 40.9 & 131.9 & 75.2 & 113.3 & 592.4 \\
\hline \multirow[t]{3}{*}{ Hungary } & TFP & -0.4 & 1.2 & -0.7 & -2.1 & -0.5 & -2.7 & -0.3 & -0.6 & 4.9 & -3.3 \\
\hline & GDP & 2.3 & 1.0 & 0.7 & -2.6 & 2.2 & 2.6 & 4.0 & 1.1 & 8.1 & 3.7 \\
\hline & TFP contribution (\%)* & -19.2 & 123.0 & -101.3 & 79.4 & -21.1 & -102.9 & -7.7 & -59.0 & 60.9 & -88.7 \\
\hline \multirow[t]{3}{*}{ Italy } & TFP & 0.9 & 1.1 & 3.4 & -3.6 & -0.6 & 1.7 & -0.3 & 1.6 & 2.4 & 2.1 \\
\hline & GDP & 0.4 & 1.6 & 2.9 & -3.7 & -2.0 & 1.7 & -0.7 & 0.8 & 1.6 & 1.6 \\
\hline & TFP contribution (\%)* & 204.4 & 70.0 & 117.0 & 97.5 & 32.0 & 101.5 & 45.8 & 205.8 & 147.0 & 131.3 \\
\hline \multirow[t]{9}{*}{ Poland } & TFP & -1.0 & -7.6 & -1.7 & 8.9 & -6.0 & 0.2 & -2.2 & 1.0 & -3.3 & 1.8 \\
\hline & GDP & 1.7 & -3.1 & 0.7 & 13.0 & -3.4 & 2.2 & 0.9 & 2.9 & -1.4 & 3.4 \\
\hline & TFP contribution (\%)* & -58.4 & 244.9 & -240.8 & 68.7 & 176.9 & 9.3 & -245.0 & 34.0 & 236.7 & 53.4 \\
\hline & L & 1.1 & 1.9 & -3.3 & 0.2 & 1.0 & 1.1 & 2.6 & 1.4 & 3.0 & 2.3 \\
\hline & K & 4.2 & 7.1 & 8.1 & 7.9 & 4.2 & 2.9 & 3.6 & 2.4 & 0.8 & 0.9 \\
\hline & L contribution (pp) & 0.6 & 1.0 & -1.7 & 0.1 & 0.5 & 0.6 & 1.3 & 0.7 & 1.5 & 1.2 \\
\hline & K contribution (pp) & 2.1 & 3.5 & 4.0 & 4.0 & 2.1 & 1.4 & 1.8 & 1.2 & 0.4 & 0.4 \\
\hline & L contribution $(\%)^{*}$ & 33.6 & -30.6 & -235.7 & 0.8 & -14.7 & 25.0 & 144.4 & 24.1 & -107.1 & 33.8 \\
\hline & K contribution (\%)* & 124.8 & -114.2 & 576.5 & 30.5 & -62.2 & 65.7 & 200.6 & 41.9 & -29.5 & 12.8 \\
\hline \multirow[t]{3}{*}{ Slovakia } & TFP & -4.6 & 7.9 & 1.7 & 5.2 & 0.2 & -2.2 & 8.9 & -15.1 & -4.9 & -42.8 \\
\hline & GDP & -3.9 & 6.2 & 1.5 & 6.7 & -0.3 & -1.9 & 9.4 & -11.5 & -2.7 & -42.3 \\
\hline & TFP contribution (\%)* & 117.9 & 127.1 & 110.6 & 77.9 & -62.3 & 118.0 & 95.1 & 131.3 & 181.4 & 101.2 \\
\hline \multirow[t]{3}{*}{ Spain } & TFP & 1.6 & 0.5 & 0.7 & -1.1 & 2.6 & 2.1 & 6.2 & 1.4 & 2.6 & -0.7 \\
\hline & GDP & 1.6 & 1.7 & 1.0 & -2.1 & 1.3 & 1.0 & 7.0 & 2.2 & 2.7 & 0.0 \\
\hline & TFP contribution (\%)* & 96.7 & 28.7 & 68.7 & 54.1 & 202.4 & 206.7 & 88.4 & 65.2 & 97.0 & - \\
\hline
\end{tabular}

* Average percentage contributions are calculated on the basis of the averaged growth rate of a given variable and the averaged GDP growth rate, and they are not an arithmetical average of values reported in successive years.

Source: Own calculations based on Eurostat [2020] data.

It is worth adding that research on the decomposition of economic growth and TFP estimates for Poland was also carried out by other Polish authors (apart from the author's own studies already quoted) ${ }^{2}$. For example, Florczak and Welfe [2000] and Welfe [2001] calculate TFP in Poland in 1982-2000 on the basis of standard growth accounting, taking into account two factors of production: labor and physical capital (machinery and equipment or total fixed assets). In their study, the elasticity of production in relation to fixed assets, i.e., the share of physical capital in income, is calibrated

2 Due to volume constrains, the results contained in those studies will not be described in detail. 
at 0.5 or estimated on the basis of the production function. In another study by Welfe [2003], TFP for Poland in 1986-2000 was estimated using various alternative values of the physical capital share in income (from 0.25 to 0.7). Florczak [2011], in turn, estimates, using the Wharton method, the TFP values cleared of short-term demand fluctuations for Poland in 1970-2008, and then examines the determinants of total factor productivity. TFP estimates for Poland were also conducted, among others, by: Zienkowski [2001], Rapacki [2002], Piątkowski [2004], and Ptaszyńska [2006]. Roszkowska [2005] and Tokarski, Roszkowska and Gajewski [2005] performed growth accounting for voivodships in Poland. Zielińska-Głębocka [2004] estimated TFP for 100 industries in Poland, Ciołek and Umiński [2007] calculated the TFP growth rate in Polish domestic and foreign enterprises, while Doebeli and Kolasa [2005] used the index number decomposition method in growth accounting for Poland, the Czech Republic and Hungary.

As regards sectoral analyses, it is worth referring to studies in this area conducted by the Polish Central Statistical Office (GUS) [Kotlewski and Błażej, 2018; see also a previous work on the subject: Kotlewski and Błażej, 2016]. In the first of the cited works, the authors use the KLEMS productivity account and estimate, inter alia, the contribution of multifactor productivity to output growth.

\subsection{Conclusions}

The results of the analysis presented show that changes in productivity played a significant role in the economic growth of Poland and the other EU-11 countries. In Poland, the average TFP growth rate amounted to 1.8\% annually between 2010 and 2019, which was the second best result (joint with Latvia) in the EU-11 group (the leader was Lithuania with a 1.9 percent productivity growth rate). TFP growth in Poland should be interpreted as an improvement of the competitiveness of the Polish economy. Higher efficiency of production factors means an increase in management efficiency and a better competitive position in the international environment. In particular, it should be emphasized that the high TFP growth rate obtained by Poland in the entire EU-11 group in 2010-2019 indicates that the competitive position of the Polish economy measured by the dynamics of total factor productivity increased considerably against the background of the new EU member states during the last 10 years.

Comparing the TFP growth rate in individual sectors of the economy, no clear difference can be seen between service sectors and other industries, including production sectors of the economy. In Poland, service sectors can be identified in which TFP was growing quickly, as well as those characterized by a low (or even negative) productivity dynamics. 


\section{Bibliography}

Abramovitz, M. [1956], Resource and Output Trends in the United States since 1870, "American Economic Review", Vol. 46, pp. 5-23.

Barton, G.T., Cooper, M.R. [1948], Relation of Agricultural Production to Inputs, "Review of Economics and Statistics", Vol. 30, pp. 117-126.

Ciołek, D., Umiński, S. [2007], Transfer technologii przez zagranicznych inwestorów, "Ekonomista", No. 2, pp. 221-234.

Doebeli, B., Kolasa, M. [2005], Rola zmian cen dóbr handlowych we wzroście dochodu krajowego Polski, Czech i Węgier, "Gospodarka Narodowa”, No. 9, pp. 25-45.

Eurostat [2020], https://ec.europa.eu/eurostat (11.02.2020).

Florczak, W. [2011], Ekonometryczna analiza makro-uwarunkowań wzrostu gospodarczego Polski, "Prace i Materiały Wydziału Zarządzania Uniwersytetu Gdańskiego", No. 4/8, pp. 75-92.

Florczak, W., Welfe, W. [2000], Wyznaczanie potencjalnego PKB i łącznej produktywności czynników produkcji, "Gospodarka Narodowa", No. 11-12, pp. 40-55.

Griliches, Z. [1964], Research Expenditures, Education, and the Aggregate Agricultural Production Function, "American Economic Review", Vol. 54, pp. 961-974.

Griliches, Z. [1996], The Discovery of the Residual: A Historical Note, "Journal of Economic Literature", Vol. 34, pp. 1324-1330.

ILO [2020], www.ilo.org/ilostat (11.02.2020).

IMF [2020], World Economic Outlook Database, October 2019 (updated January 2020), www. imf.org (11.02.2020).

Johnson, D.G. [1950], The Nature of the Supply Function for Agricultural Products, "American Economic Review", Vol. 40, pp. 539-564.

Jorgenson, D.W., Griliches, Z. [1967], The Explanation of Productivity Change, "Review of Economic Studies", Vol. 34, pp. 249-283.

Kendrick, J.W. [1956], Productivity Trends: Capital and Labor, "Review of Economics and Statistics", Vol. 38, pp. 248-257.

Kotlewski, D., Błażej, M. [2016], Metodologia rachunku produktywności KLEMS i jego implementacja w warunkach polskich, "Wiadomości Statystyczne", No. 9(664), pp. 86-108.

Kotlewski, D., Błażej, M. [2018], Rachunek produktywności KLEMS - Polska 2005-2016, Główny Urząd Statystyczny, Warsaw.

Piątkowski, M. [2004], Wpływ technologii informacyjnych na wzrost gospodarczy i wydajność pracy $w$ Polsce w latach 1995-2000, "Gospodarka Narodowa", No. 1-2, pp. 37-52.

Próchniak, M. [2012], Total Factor Productivity, in: M.A. Weresa (ed.), Poland. Competitiveness Report 2012. Focus on Education, SGH Publishing House, Warsaw, pp. 198-212.

Próchniak, M. [2014], Changes in Total Factor Productivity in 2004-2013 and the Competitiveness of the Polish Economy, in: M.A. Weresa (ed.), Poland. Competitiveness Report 2014. A Decade in the European Union, SGH Publishing House, Warsaw, pp. 201-213. 
Próchniak, M. [2019] Changes in Total Factor Productivity in the Fourth Industrial Revolution Era, in: A.M. Kowalski, M.A. Weresa (eds.), Poland. Competitiveness Report 2019. International Competitiveness in the Context of Development of Industry 4.0, SGH Publishing House, Warsaw, pp. 231-244.

Ptaszyńska, B. [2006], Wzrost gospodarczy $w$ Polsce $w$ latach transformacji systemowej, "Wiadomości Statystyczne”, No. 2, pp. 44-53.

Rapacki, R. [2002], Możliwości przyspieszenia wzrostu gospodarczego w Polsce, "Ekonomista", No. 4, pp. 469-493.

Roszkowska, S. [2005], Kapitał ludzki a wzrost gospodarczy w ujęciu wojewódzkim, "Wiadomości Statystyczne", No. 4, pp. 46-67.

Ruttan, V.W. [1956], The Contribution of Technological Progress to Farm Output: 1950-1975, "Review of Economics and Statistics", Vol. 38, pp. 61-69.

Schmookler, J. [1952], The Changing Efficiency of the American Economy, 1869-1938, "Review of Economics and Statistics", Vol. 34, pp. 214-231.

Solow, R.M. [1957], Technical Change and the Aggregate Production Function, "Review of Economics and Statistics", Vol. 39, pp. 312-320.

Solow, R.M. [1962], Technical Progress, Capital Formation, and Economic Growth, "American Economic Review", Vol. 52, pp. 76-86.

Tintner, G. [1944], A Note on the Derivation of Production Functions from Farm Records, "Econometrica", Vol. 12, pp. 26-34.

Tokarski, T., Roszkowska, S., Gajewski, P. [2005], Regionalne zróżnicowanie łącznej produktywności czynników produkcji w Polsce, "Ekonomista", No. 2, pp. 215-244.

Welfe, W. [2001], Czynniki wzrostu potencjału gospodarczego Polski, "Ekonomista", No. 2, pp. 177-200.

Welfe, W. [2003], Łączna produktywność czynników produkcji a postęp techniczny, "Studia Ekonomiczne", No. 1-2, pp. 99-115.

World Bank [2020], World Development Indicators Database, databank.worldbank.org (11.02.2020)

Zielińska-Głębocka, A. [2004], Analiza produkcyjności polskiego przemystu. Aspekty metodyczne i empiryczne, "Ekonomista", No. 3, pp. 335-358.

Zienkowski, L. [2001], Wydajność pracy i kapitału w Polsce, "Wiadomości Statystyczne”, No. 2, pp. 36-49. 


$$
\text { Part IV }
$$

Service Sector Development Trends and Challenges 

Chapter 12

\title{
New Tendencies in International Service Flows
}

\author{
Andżelika Kuźnar
}

\subsection{Introduction}

The importance of services in the global economy is constantly growing. Most countries are experiencing changes in their economies as the dominant sector in GDP and job creation shifts from agriculture to industry to services. A strong positive correlation can be found to exist between economic development and the share of services in GDP and employment. On average, services worldwide account for almost $65 \%$ of GDP, with 49\% of the population employed in the service sector, while in OECD countries services represent $70 \%$ of GDP and more than $73 \%$ of the population employed in the service sector [WDI, 2019]. At the same time, the importance of services in international trade is growing faster than that of agricultural and manufacturing products, although services still account for only $23 \%$ of global exports.

However, it is reasonable to ask to what extent the data illustrating trade in services faithfully reflect reality. Firstly, they do not take into account the fact that many services are provided by locally by foreign entities, so such transactions cannot appear in the balance of payments statistics which record transactions between residents and non-residents. Secondly, they do not contain any information on the value added by services in the production of goods and services which are subsequently exported. In other words, they do not take into account the role played by services in global value chains.

The purpose of this chapter is to present the results of an analysis of the latest trends in international trade in services. The study explores new ways of measuring international trade in services, making it possible to express the value of services in real terms, both according to the modes of provision adopted in the General Agreement on Trade in Services, and according to value added in trade. In addition to standard gross exports data, the latest data from the TISMOS (trade in services data by mode of supply) data set and the TiVA (trade in value added) database were used. Presented 
next are major changes in the modes of service provision from the $19^{\text {th }}$ to the early $21^{\text {st }}$ century, factors affecting the development of trade in services in the $21^{\text {st }}$ century and, more specifically, the impact of digital technologies on trade in services.

Changes in business processes specific to Economy 4.0 may lead to a further rapid increase in the importance of services in the global economy.

\subsection{Improvements of Measurement Methods and the Size of Trade in Services}

Traditionally defined international trade in services involves transactions between residents and the rest of the world [Kuźnar 2007, p. 54]. The rules for measuring such trade are contained in the International Monetary Fund's Balance of Payments and International Investment Position Manual. According to the definition provided there, "services are the result of a production activity that changes the conditions of the consuming units, or facilitates the exchange of products or financial assets" (IMF 2013, p. 149). The IMF has given a quasi-formal status to a widely accepted scientific definition. Hill, on the other hand, pointed out that the "a service may be defined as a change in the condition of a person, or a good belonging to some economic unit, which is brought about as a result of the activity of some other economic unit" [Hill, 1977, p. 318]. In order for a service to be provided, a specific relationship between the producer and the consumer is necessary. The provision of a service cannot take place without the consent, cooperation and possibly active participation of the consumer, and the result of the service delivery process must have a positive effect on the consumer (or a good belonging to him) and cannot be separated from him. In this process, no new good is created for which ownership rights could be established and which could be subject to further exchange. At the same time, it is a fundamental distinguishing feature of services, making them different from goods (both tangible and intangible ${ }^{1}$ ).

The consequence of the very essence of services is that it is not possible to separate their provision from consumption (sale) and, therefore, trade in services takes place, in principle, at the same time and place as their production and consumption. This need for face-to-face contact between the producer and the consumer of services has traditionally been the reason for treating services as non-tradables and their relatively low share in international trade. In 1980 (the first year for which data on

\footnotetext{
1 For more on the effects of production activities, i.e. tangible goods, intangible goods and services,
} see Kuźnar [2017, pp. 53-64]. 
global exports and imports of services are available), the share of commercial services ${ }^{2}$ in global exports amounted to around 15\%, while in 2018 it increased to 23\% (see Figure 12.1). The WTO forecasts that by 2040 services could account for up to a third of world trade [WTO 2019a, p. 14].

Figure 12.1. Share of market services in global exports between 1980 and 2018 (in \%)

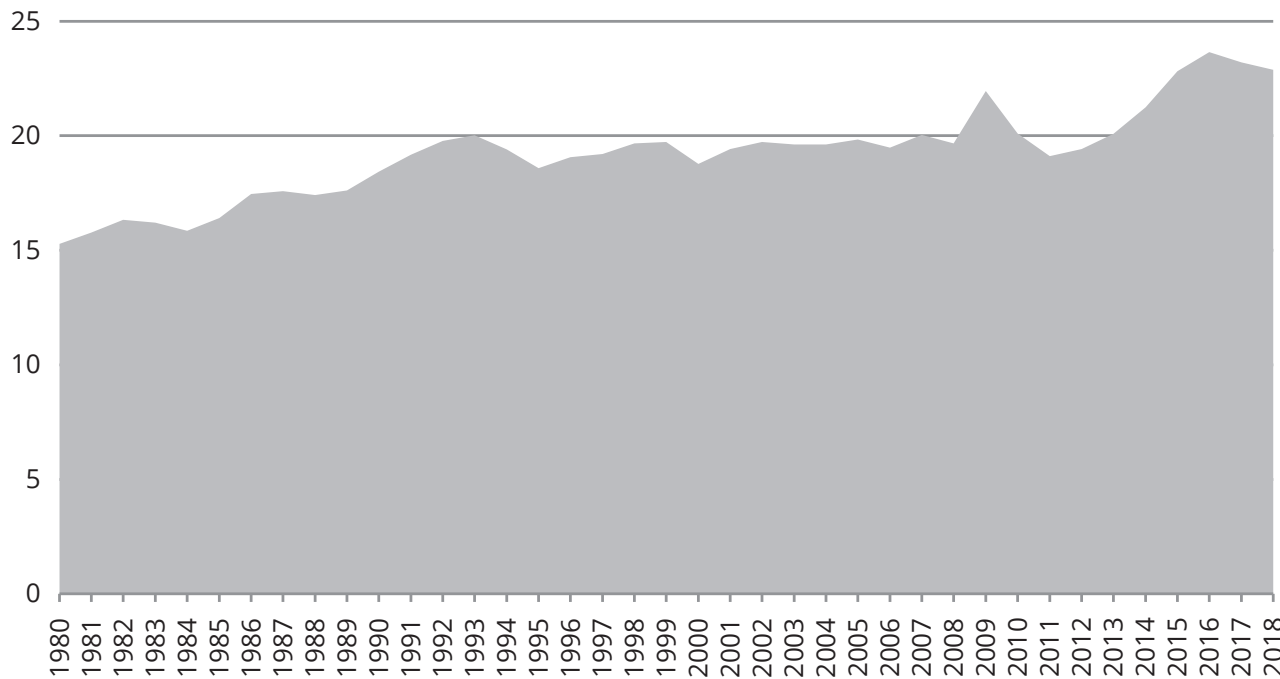

Source: Own study based on WTO Data [2019].

In the $21^{\text {st }}$ century, many services can be delivered abroad more easily than in the past. This is possible both as a result of the emergence of technical capabilities for the provision of services at a distance (e.g., through digital recording) and the decreasing costs of telecommunications and travel reducing trade costs ${ }^{3}$ [Kuźnar, 2017, p. 62]. As a result, a much faster average annual growth is observed in service exports than in goods exports ${ }^{4}$, both throughout the 1980-2018 period and in each 10-year sub-period (see Figure 12.2). The biggest differences between the growth rates of exports of services and goods were recorded in 1980-1990 and 2010-2018.

The first period was characterized by the dissemination of the Internet and deregulation in the telecommunications industry [Baldwin, 2006], resulting in effects such as offshoring of service activities. The second ones involves the development of

\footnotetext{
2 Commercial services are all services with the exception of government services.

3 However, there is still a need for interaction between the two parties to the service transaction, which means, e.g., that the duration of the provision of services has to be adjusted to the demand from consumers. 4 The terminology according to which the products traded in the market are called commodities has been adopted. They can be goods or services. According to another approach, used, e.g. by micro-economists, services are goods (because they satisfy needs) and not commodities.
} 
communication technologies, allowing face-to-face contacts to be omitted, and their falling costs. In 2018, the value of global commercial services exports was USD $5.8 \mathrm{tr}$, while in 2010 it was around 5.8 tr, i.e. approx. one-third less (see Figure 12.3).

Figure 12.2. Average annual growth in exports of services and goods in 1980-2018 (in \%)

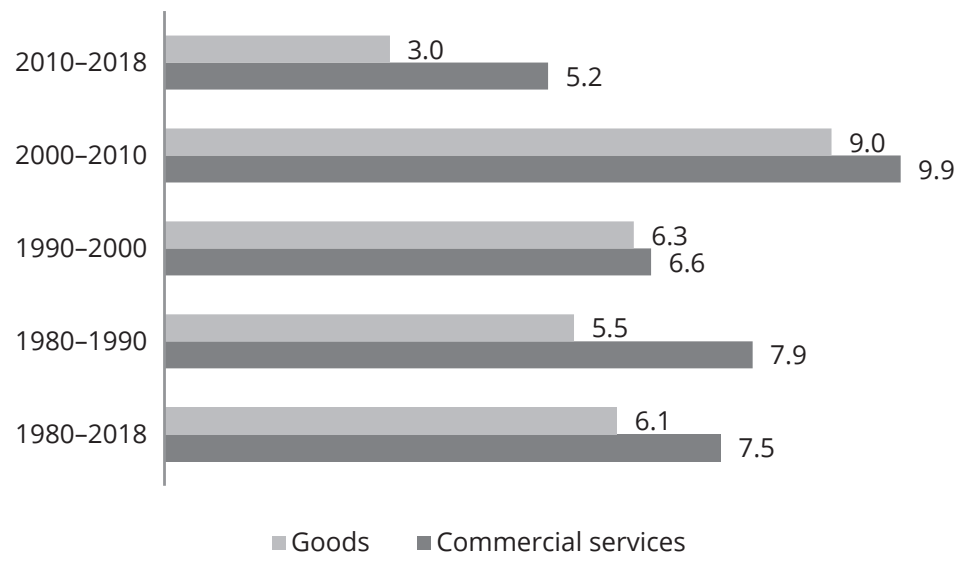

Source: Own study based on WTO Data [2019].

Figure 12.3. Global exports of commercial services 2010-2018 (in USD tr)

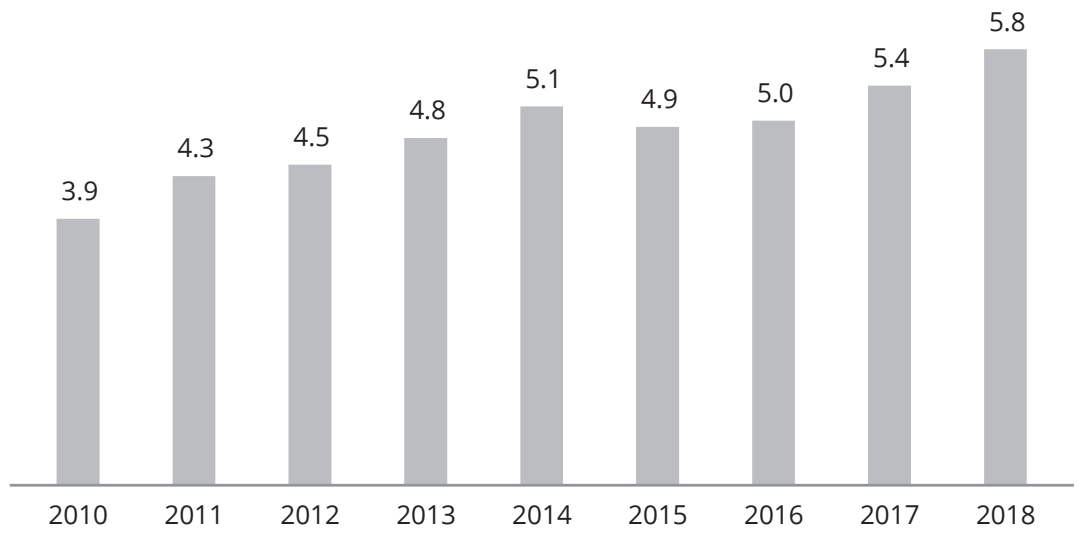

Source: Own study based on WTO Data [2019].

The services whose exports grew particularly rapidly between 2010 and 2018 are the so-called other commercial services (excluding transport and travel), including services which usually do not require the movement of people, such as information, R\&D, consulting, charges for the use of intellectual property and repair services ${ }^{5}$ (Figure 12.4).

5 Repair (and maintenance) services include maintenance and repair work for goods owned by non-residents, performed by residents (and vice versa). This category includes, among other services, the repair 
Figure 12.4. Average annual growth in exports of selected service industries in 2010-2018 (in \%)

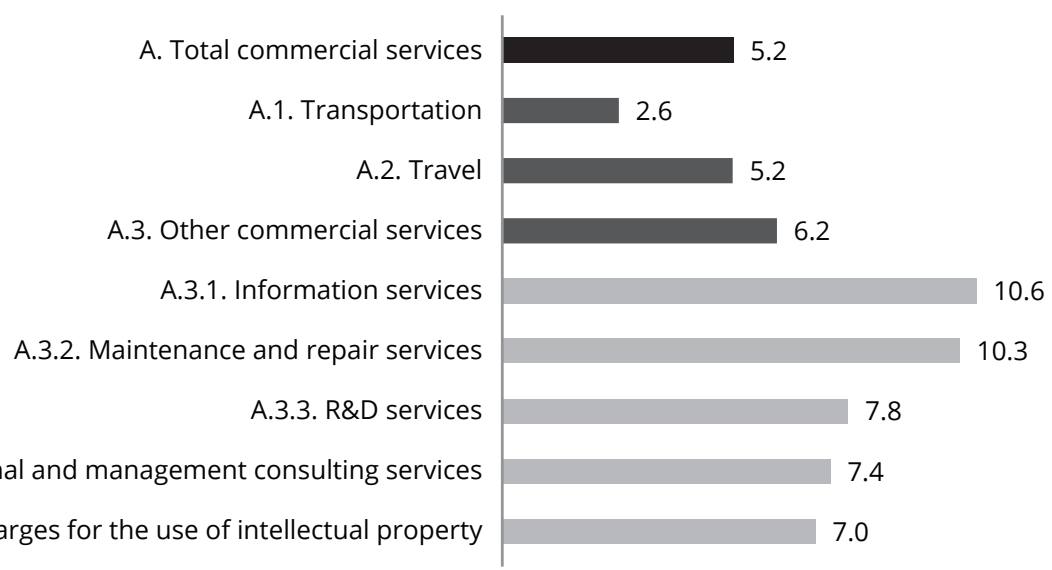

Note: Service categories are given in a hierarchical structure; category A. consists of A.1-A.3, A.3 consists of A.3.1-A.3.5 (5 industries with the highest export growth have been selected).

Source: Own study based on WTO Data [2019].

The statistics presented on international trade in services cover only part of the international trade in services. The provision of services may involve many other modes than the traditional export and import. The requirement of simultaneous provision and consumption of many services determines the mode of service delivery in the international market. The General Agreement on Trade in Services (GATS) established the following categorization for the international provision of services (GATS 1995):

- Mode 1 (M1): cross-border supply, e.g., services provided by consultants, doctors, lawyers over the Internet, telephone, video channels;

- Mode 2 (M2): consumption abroad, e.g., travel, study, hospital stay, as well as repair of a consumer's equipment carried out abroad;

- Mode 3 (M3): commercial presence, e.g., foreign direct investment in service industries;

- Mode 4 (M4): presence of natural persons, e.g. consultants, architects, athletes, musicians providing their services abroad.

and maintenance of ships, aircraft and other transport equipment. The high growth rate of their exports can be linked to an increase in the production of means of transport, the consolidation of manufacturers and the concentration of service centers. According to the WTO, trade costs (calculated as a ratio of international costs to domestic costs) for the sale, maintenance and repair of motor vehicles have also decreased significantly since 2010 [WTOa, 2019, p. 87]. 
Taking all these modes of service provision into account, the global trade in services $^{6}$ is estimated at USD $13.4 \mathrm{tr}$ in 2017, i.e. approx. 60\% more than if measured in the traditional way. This difference is mainly due to the size of commercial presence in the provision of services (cf. Figure 12.5). In 2017, it accounted for $59 \%$ of trade in services, compared with $28 \%, 11 \%$ and $3 \%$ for modes 1,2 and 4 , respectively.

Figure 12.5. Global trade in services by mode of supply in 2005-2017 (in USD tr)

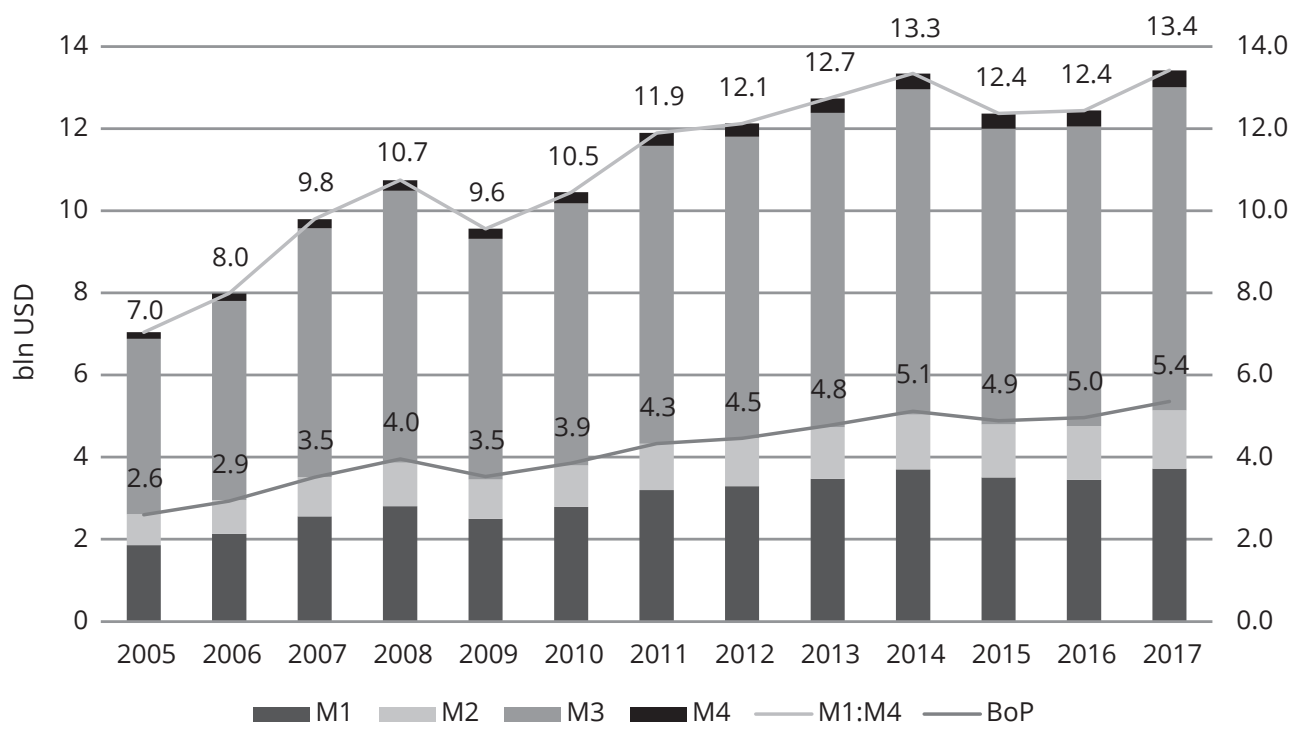

Source: Own study based on TISMOS [2019] and WTO Data [2019].

The data presented clearly show the changes taking place in international trade in services. Not only the value of this trade is increasing but also the share of services in world trade. Furthermore, thanks to new measurement methods, we know that commercial presence which is not included in conventional trade in services represents a dominant share of the provision of services.

Traditional trade statistics do not include yet another mode of service supply in foreign markets. With the development of information and communication technologies

6 Data on the activities of foreign affiliates statistics (FATS) are used to estimate the trade volume in Mode 3. In the past, due to the lack of such data, FDI stock was used for measurement of the use of Mode 3. However, the FDI and FATS statistics reflect different aspects of the role that multinationals play in the global economy. FATS describes the activities of affiliates controlled by foreign entities in the economy (inward FATS) and the activities abroad of the affiliates of domestic enterprises (outward FATS). The value of output is taken as the value of the provision of services in Mode 3. For most service industries, this will be the same value as sales (or turnover) because for most services there is no work in progress or inventory. Cf. Wettstein et al., 2019. 
(ICT), the ways in which international production is organized have changed, with increasing interconnection between countries, businesses and sectors within global value chains. Traditional trade data (exports and imports by gross value) do not take into account the value added, produced in particular sectors and industries, which make up the value of the final product. Services such as research and development, design, transport, insurance and finance are essential for the creation of most manufacturing and agricultural products. Trade data allow the exports and imports of goods to be determined based on the value of the final product (e.g., a laptop or new plant variety). The measurement of value-added trade flows shows that services account for around $49 \%$ of world trade and this share is steadily increasing (cf. Figure 12.6).

Figure 12.6. Structure of world trade by value added (in \%)

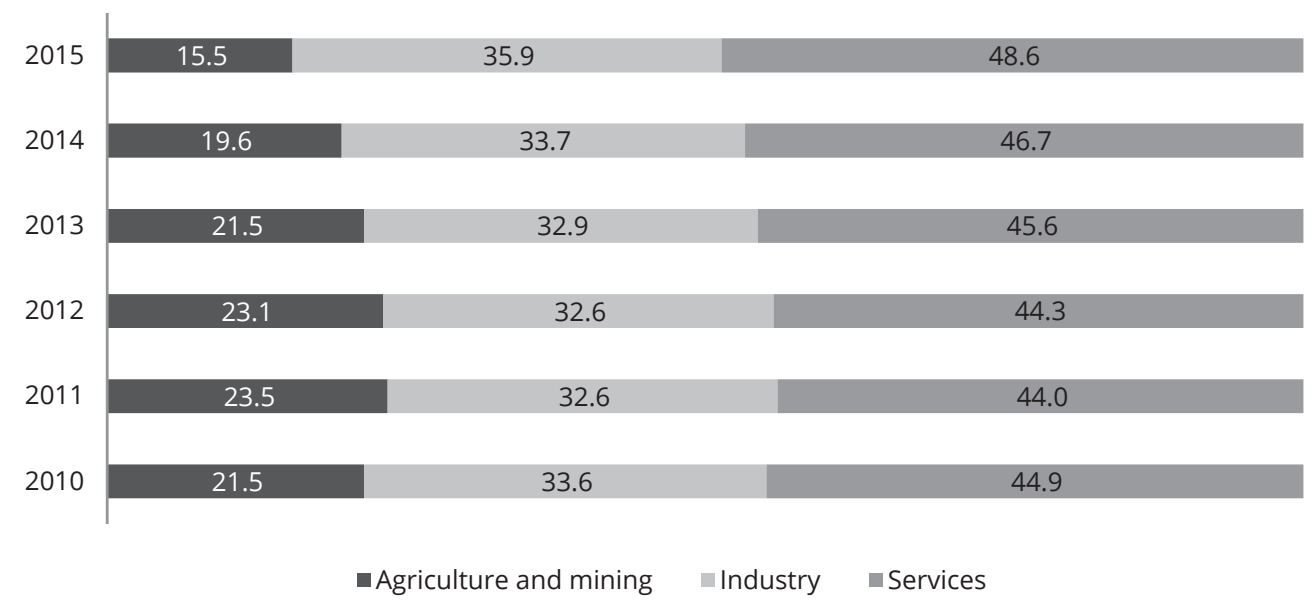

Source: Own study based on TiVA [2018].

Thus, the traditionally measured $23 \%$ share of services in world trade is actually much higher. This also means that, with the development of global value chains, the importance of services in world trade will be increasing.

\subsection{The Evolution of Service Provision}

The development of digital technology and electronics, as well as the related integration of digital and physical systems in all sectors of the economy, cause the new way of doing business known as Industry 4.0 or Economy 4.0 to become increasingly common [for more, see Kuźnar, 2019, p. 49-67]. The evolution of the modes of service provision is also seen to evolve, up to the stage called Service 4.0 (see Figure 12.7). 
Figure 12.7. The evolution of service provision

Service 1.0

Non-standardized service provided using traditional methods
Service 2.0

Standardized services, provided remotely,

"industrialized", relatively labor-intensive
Service 3.0

Partly automated services, less labor-intensive

Service 4.0

Customized services, multiple delivery channels, prosumerdefined service, shared, open infrastructure

\section{Early $21^{\text {st }} \mathrm{c}$.}

Development factors: progress in ICT, Big Data, Al, IoT computers, Internet, open standard

E.g., online sales

E.g., autonomous shops

E.g., supermarket, where customers themselves perform many tasks

Source: Own study based on Rehse, Hoffmann and Kosanke [2016].

The services provided in the first stage (Service 1.0 ) in the $19^{\text {th }}$ century were mainly carried out by traditional methods - they required personal (often even manual) involvement in order to perform a contract. They were rarely standardized, because involving a person in the provision of services makes it much more difficult to ensure the exact repeatability of activities. In the first half of the $20^{\text {th }}$ century, with the development of telephone communications, the Internet and new methods of management (Taylorism), services began to be provided in a more standardized way. They could be provided over longer distances, standardized, "industrialized". The latter concept meant that it was possible to use: 1 ) instead of people, machines and equipment, such as a price barcode scanner, 2) organized work systems, often modifications and substitutes for previously used tools or technologies, which are redesigned to achieve higher efficiency, such as supermarkets, open-access libraries, fast-food restaurants, 3) a combination of items from categories 1 and 2 to increase the efficiency, order and speed of service, such as selecting routes for truck transport using data entered into the computer and modified by taking into account the situation in real time. By identifying road types and classes, location of stops, traffic intensity and toll costs, the system optimizes the use of trucks and minimizes operating costs [Levitt, 1976]. This was a period of Service 2.0 development. At the end of the $20^{\text {th }}$ century, the widespread use of computers and the Internet, as well as the accompanying open standard, allowed enterprises to partially automate the provision of services, integrate value chains and start offering the first generation of self-service terminals. As a result, labor intensity and, consequently, the costs of many services decreased. Most service firms in highly developed countries are at this stage of service development (Service 
3.0). Finally, the last, fourth stage involves the provision of highly customized services through multiple channels (telephone, Internet, on-site). Consumer data collected in Big Data repositories, the Internet of Things (IoT), artificial intelligence (AI), etc. are used for this purpose. The consumer is proactive (prosumer), expects personalization, a quick response to his or her changing tastes and needs [Rehse, Hoffmann and Kosanke, 2016]. Firms that can integrate data from different sources (e.g., social media, orders and purchases, etc.) are able to create consumer profiles and target them with customized offers. Examples of such companies are Amazon, Netflix or Spotify. In the case of the first one, the consumer receives, e.g. recommendations to purchase books or magazines, and in the second case - to watch more movies based on their previous preferences. Spotify offers songs/artists based on previously played tracks. This is the bright side of the services provided using the collected data. But there is also a darker side to it. At one time, political parties ordered a service that involved sending false information to voters to confirm their beliefs and encourage certain electoral behavior.

\subsection{Factors Influencing the Development of Trade in Services in the $21^{\text {st }}$ Century}

The provision of services is influenced by many factors, the weights of which change over time. Today, trade costs, demographic trends, income levels, climate change, and technological development are the most important. Due to the paper word count guidelines, only the basic facts concerning these factors have been identified [see also WTO, 2019a].

As regards the issue of trade costs ${ }^{7}$, it is known that they are almost twice as high in services than in trade in goods, but between 2000 and 2017 they decreased by about 9\% thanks to digital technologies, reduced political barriers and investment in infrastructure. Industries with particularly low trade costs are transport and logistics, wholesale trade, so-called other business and professional services, post and telecommunications, financial intermediation, and other services such as community, environmental, cultural and personal services. On the other hand, the highest trade costs are recorded in the case of real estate activities, retail trade, motor vehicle sales, and construction. A common feature of these services is that they are difficult to trade internationally, which is why they are usually produced and consumed at the place of

7 The WTO defines trade costs as the average of both export and import costs. They represent the ratio of international to domestic trade costs [WTO 2019a, p. 84]. 
production. Online sales (e.g., for motor vehicles) contribute to a gradual reduction in these costs [WTO 2019a, p. 86].

Demographic trends are conducive to the development of services in economies [Wróbel, 2009, pp. 69-70), as well as their presence in international trade. In developed countries, average life expectancy is longer, the number of elderly people is increasing, there is a low fertility rate and thus the share of economically active people in the population is reduced. In contrast, reverse trends are witnessed in developing countries - high fertility rates combined with declining mortality rates lead to population growth across all age groups [WTO 2019a, p. 106]. Such directions of demographic change are causing a growing demand for medical and paramedical services, as well as leisure services in high-income countries, as well as educational and urban services (transport, culture, restaurants, entertainment) - in lower-income countries. The result is a change in the level and structure of demand, e.g. to services imported from abroad, and the comparative advantages of countries are changing, which has a twofold impact on trade in services. In developed countries, for example, the demand for people working in medical professions exceeds their supply, which can be supplemented by "importing" such skills both in the traditional way, i.e., by physically moving them between countries and at a distance, through digital technologies. The same is true for students - they can either come to study in developed countries or use online tools to significantly reduce the cost of education ${ }^{8}$.

Another factor influencing the development of trade in services is the change in the level of wealth of societies. The impact of income on the structure of consumption is known and determined by Engel's law. According to it, the share of food or - in general - goods with low income elasticity of demand in total expenditure decreases with the increase in income, while the share of expenditure on goods with high income elasticity of demand increases. This is a characteristic feature of many services [Caron, Fally and Markusen, 2014], in particular those that satisfy higher needs [Wróbel, 2009, p. 75]. The latest data show, for example, that, as the level of income increases, the share of spending on hotels and restaurants, health and social, recreational, financial and professional services increases, while the share of spending on real estate services, represented by rent expenditures, declines steeply [WTO 2019a, p. 116]. Services with higher income elasticity of demand are at the same time services that require higher skills on the part of service providers. An increase in trade in skill-intensive services can thus be anticipated, which may be trade in both services per se and in goods containing such services, which represent an indirect input to final production. Since

8 There is an open question how the online studying forced by the outbreak of the COVID-19 pandemic will impact the higher education sector globally and in particular countries. 
mainly developed countries specialize in the production and consumption of such services, two-way trade between countries with a similarly high level of wealth can be expected. There may also be an intensification of trade in services provided by highly skilled persons with the progressing equalization of wealth levels between countries.

Climate change is another factor that could affect trade in services. Global warming, changes in humidity and precipitation distribution have an impact not only on the environment, but also on the economy. However, there is no detailed study on the impact of climate change on trade in services, other than research on the impact of these changes on transport and distribution costs (e.g. energy) as well as on the tourism industry. Overall, the impact of such changes on trade in services is likely to depend on the region and industry, as well as on the sensitivity and vulnerability of countries to climate-related events [WTO, 2019a, p. 118-119]. There are also prospects for the development of new services and stimulation of existing ones, related to environmental protection. This concerns, among other things, the management of solid and hazardous waste, water and wastewater treatment, as well as engineering design, environmental consulting services, environmental protection technology systems, and environmental reclamation [Kommerskollegium, 2014]. The growth of trade in insurance services also has good prospects. Insurance systems are considered an effective tool for reducing climate-related economic vulnerability [Golnaraghi, 2018]. In the face of an increasing occurrence of extreme weather events, the demand for such systems is growing and related trade may be facilitated by the fact that some of the risks (e.g., storm surges) are not covered by popular and low-cost insurance, while others are insured only in certain countries (or even in selected areas). However, too high a weather risk may be an obstacle to the development of insurance services, as the companies providing them can limit the coverage, increase premiums, and transfer risks [WTO 2019a, pp. 121-122].

\subsection{Impact of Digital Technologies on Trade in Services}

The development of digital technologies is one of the most important factors that may be crucial in the future to the development of trade in services. Owing to progress in this area, an increasing number of service industries have succeeded in overcoming one of the greater barriers to trade in services, i.e., the need for the provider to physically contact the recipient. Falling telephone call and data transmission prices, along with growing capabilities to code increasingly large volumes of data, allow differences in labor costs between countries to be leveraged and services to be transferred across borders at a cost close to zero. Initially, these were simple tasks, such as call centers, 
data entry, uncomplicated coding, while today they are increasingly complex business processes such as system designing as well as research and development. There is a clear shift from cost factors to factors based on innovation and quality.

These changes are reflected in the rapid growth of cross-border trade (Mode 1 according to GATS terminology) of various types of ICT-based services (services provided remotely over ICT networks). ${ }^{9}$ Between 2005 and 2017, exports of these services grew at a rate of $7.3 \%$ on average per year, while the provision of all services in Mode 1 grew by $6 \%$ during that time and trade in services using all four modes increased by $5.5 \%$ on average per year. ${ }^{10}$ Cross-border provision of ICT-based services more than doubled during the period considered (see Figure 12.8).

Figure 12.8. Cross-border provision of ICT-based services in 2005-2017 (in USD bn)

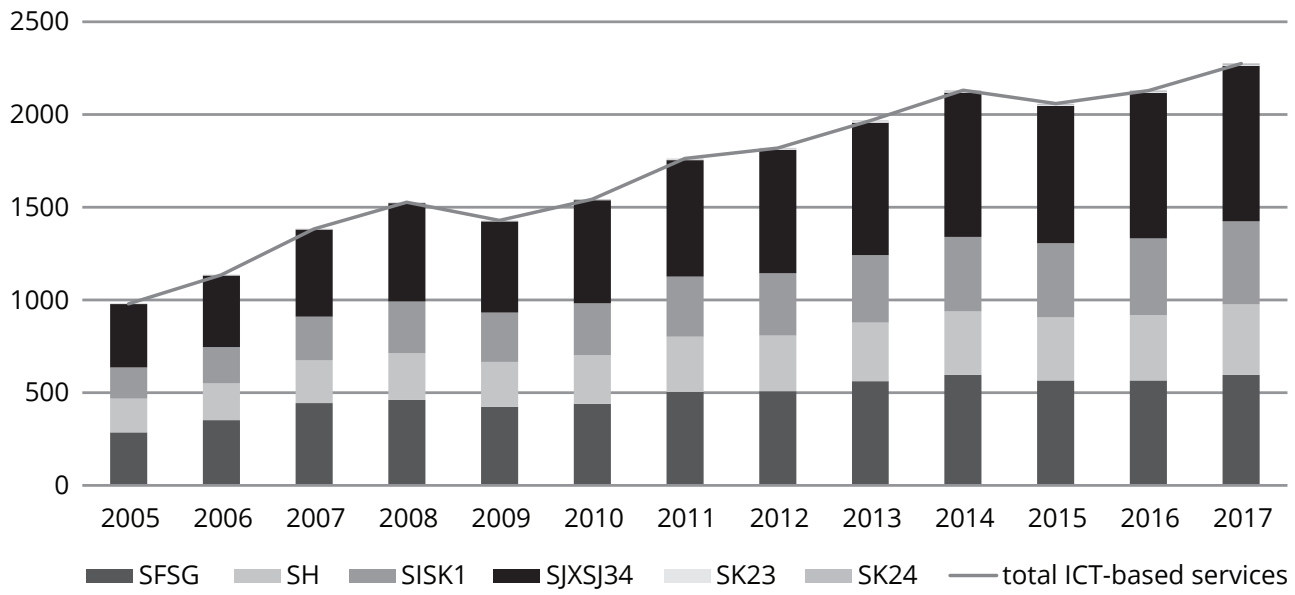

Note: SFSG - financial and insurance activities; SH - charges for the use of intellectual property; SISK1 - telecommunication, computer and information services; SJXSJ34 - other business services; SK23 - heritage and recreational services; SK24 - other personal services.

Source: Own study based on TISMOS [2019].

The impact of digital technologies on the growth of trade in services is effected through multiple channels. In addition to the already mentioned falling costs of providing services in international markets, these are:

- new ways of service delivery;

- acceleration of globalization processes;

- the possibility for enterprises to establish a presence in service markets regardless of their size and country of origin;

9 ICT-based services have been identified and classified by UNCTAD [2015].

10 Own calculations. 
- the decreasing level of exclusion of different groups of people from the provision of services;

- substitution of tangible goods by services;

- the possibility of achieving economies of scale and scope.

The opportunities offered by the Internet mean that services that have traditionally required face-to-face contact between both parties to a transaction can increasingly often be provided at a distance. Many professional services have been created in cross-border trade thanks to the emergence of online platforms. Thus, it is no longer necessary to bring in IT, finance or consulting specialists from abroad, which was both expensive and often complicated. Online platforms also allow freelancers around the world to be commissioned with small tasks, such as organizing photos or transcription of audio material, which would be completely unviable financially in the past. The widespread Internet access and speed of online connections, in combination with other facilities, such as cloud computing, big data operations, artificial intelligence, geolocation, and the dissemination of various payment solutions also make it much easier to manage and coordinate the work of people around the world. Enterprises are already not only taking advantage of the opportunities offered by outsourcing, but also increasingly often make use of crowdsourcing. While in the former case the delegation of tasks to external firms involves a fixed location of the place of work, usually within specific working hours, in the latter case the principal outsources tasks to an unidentified, usually very broad, group of people who are available non-stop, prefer flexible forms of employment and do not have a permanent place of work [Paliński, 2016]. This eliminates time and geographical boundaries.

This leads to further acceleration of globalization processes. This has happened twice in the past. First in the $19^{\text {th }}$ century, when transport costs decreased due to the invention of the steam machine, steamers and railway (industrial revolution), and then at the end of the $20^{\text {th }}$ century, when communication and coordination costs decreased dramatically due to the development of ICT (information revolution) [for more on this on this subject, see Baldwin, 2016; Kuźnar, 2019, pp. 49-52]. The costs of face-to-face communication are the last obstacle to the further development of globalization. However, they have also been falling steadily. New ways are emerging to reduce the need for both cognitive (mental) and manual (physical) service providers to physically cross borders [Baldwin, 2016, pp. 47-110]. Telepresence and teleworking are no longer science fiction but reality although - especially in the case of teleworking - it is still expensive. Some large banks and businesses and government agencies set up dedicated rooms to enable co-workers' presence "at a distance", doctors monitor - using cameras and microphones - the work of colleagues in other hospitals, some companies use the robot interface to communicate with employees 
in remote corners of the world. The outbreak of the Covid-19 pandemic showed how many services can be provided at a distance and how much work can be done remotely. However, high costs and regulatory issues are a serious barrier to the use of telerobotics, but, e.g., in 2001, a surgeon in New York performed the first remote surgery on a patient in Strasbourg [Baldwin 2016, p. 169]. The further development of such services depends on progress in ICT, including the 5G technology, which will allow data transmission speeds to be doubled.

Trade in services is facilitated by the increasing availability of ICT for small and medium-sized enterprises (SMEs) in both developed and developing countries, even though the average small or medium-sized enterprise is a less advanced user of digital technologies [Kuźnar and Żukowska, 2019, pp. 301-310). The growth of the digital economy reduces the cost of information search, facilitates data sharing, and provides new opportunities for marketing, finance, and networking. All this reduces trade barriers and costs, especially in the case of service SMEs, as such activities usually require lower capital investment than the agricultural, mining or manufacturing sectors [WTO, 2019a, p. 42]. It is also becoming increasingly easy for them to access foreign markets through online sales and e-commerce. Traditionally, only large companies have been able to bear the costs associated with a new export direction [Melitz, 2003]. New digital solutions can help overcome export challenges such as small domestic markets, remoteness from global markets, and other negative geographical factors [UNCTAD, 2017, p. 43]. At the same time, the opportunities for SMEs from developing countries to become involved in international production within global value chains [WTO 2019b] are increasing. SMEs also have the advantage of greater flexibility which allows them to adapt relatively quickly to market changes, while in larger companies decision-making is more time-consuming.

Another channel of impact of digital technologies on the development of trade in services is the increasing ability of previously excluded groups to provide services. One example are people who are not sufficiently familiar with foreign languages to provide services in foreign markets. In recent years, however, there has been a radical improvement in the quality of machine translation. The breakthrough in this field came in 2016, when the United Nations, the Parliament of Canada, the European Parliament, and the European Commission posted online millions of human-translated sentences. From that moment on, artificial intelligence has been learning to translate contextually, instead of word by word (WTO 2019a, p. 126). Soon millions of talented freelancers, including those in developing countries, will be able to communicate in foreign languages, replacing workers from countries with higher labor costs.

Trade in services is also boosted by the blurring line between goods and services thanks to digital technologies. Firstly, the cost of creating, copying and transmitting 
text, audio and video recordings has decreased significantly, which causes this type of trade in goods stored on physical media to be steadily reduced. The cost of physically producing additional copies (without the risk of demand estimation) of a newspaper, book, movie, or sound recording, its delivery to the final seller, storage, destruction in distribution and unsold copies is also eliminated. The good is delivered immediately and directly to the buyer in response to actual demand. Secondly, ownership of goods is increasingly replaced by access to them by renting, and therefore ultimately by services. Thanks to the availability of digital platforms, mobile applications, smartphones, social media, the sharing economy is growing. Instead of owning a car for one's own use, Uber or Blablacar services are used. Strangers are allowed to use a room in an apartment (Airbnb) or the whole house during a vacation (HomeAway). Products are ordered for home delivery (Deliveroo, UberEats) and various housework tasks are outsourced (TaskRabitt). Freelancers offer their time and skills on platforms on demand and provide various professional services (Upwork, Fiver, Freelancer.com). Instead of borrowing from banks, project financing is sought through crowdfunding (Kickstarter, Upstart). Thirdly, the increasing prevalence of 3D printing promotes the development of trade in services (programming, design) rather than final products. These are printed at the destination, based on data that has been transmitted across borders [WTO 2019a, p. 103].

The last channel of impact of digital technologies on trade in services is associated with an increase in economies of scale and scope. Firstly, digitalization allows service providers to easier reach larger numbers of (digitally connected) customers - firms and individual customers - more easily and facilitates outsourcing for easier scaling of production, e.g., in the case of growing demand. This is easier in that the costs of distributing digital content-based services are often close to zero and the flexibility of service providers is sometimes greater than for traditional traders with physical production and delivery constraints [WTO 2019a, p. 104]. Secondly, digitalization allows the scope of services provided to be expanded. In addition to the original service activities, accompanying services are often developed, e.g. the online sale of products can be supplemented by services including storage, logistics, electronic payments, as well as lending and insurance.

\subsection{Conclusions}

Changes in the global economy related to the so-called digital revolution (Revolution 4.0) mean that services that have held an undisputed high position in national economies for years have the potential to gain an adequately high position in international 
trade. This is partly the result of a better measurement of trade in services, but there is no doubt that digital technologies also significantly affect changes in the way services are provided internationally, as well as the emergence of completely new services. The geographical structure of trade in services is also changing - thanks to the opportunities that have emerged with the development of Economy 4.0, developing countries can successfully go beyond the provision of transport and tourism services and start offering modern, ICT-based services. At the same time, it is an opportunity for them to get out of the trap they can fall into when routine tasks are increasingly performed by robots.

\section{Bibliography}

Baldwin, R. [2006], Globalisation: the great unbundling (s), mimeo.

Baldwin, R. [2016], The Great Convergence. Information Technology and the New Globalization, The Belkap Press of Harvard University Press, Cambridge-Massachusetts.

Caron, J., Fally, T., Markusen, J.R. [2014], International Trade Puzzles: A Solution Linking Production and Preferences, "The Quarterly Journal of Economics", No. 129, Vol. 3, pp. 1501-1552.

GATS [1995], General Agreement on Trade in Services, https://www.wto.org/english/docs_e/ legal_e/26-gats_01_e.htm (15.11.2019).

Golnaraghi, M. [2018], Climate Change and the Insurance Industry: Taking Action as Risk Managers and Investors, The Geneva Association, Zurich, https://www.genevaassociation.org/sites/ default/files/research-topics-document-type/pdf_public//climate_change_and_the_ insurance_industry_-_taking_action_as_risk_managers_and_investors.pdf (30.11.2019).

Hill, T.P. [1977], On Goods and Services, "The Review of Income and Wealth", Vol. 23, No. 4, December.

IMF [2013], Balance of Payments and International Investment Position Manual, $6^{\text {th }}$ edition, IMF. Kommerskollegium - National Board of Trade [2014], Making Green Trade Happen: Environmental Goods and Indispensable Services, Stockholm, https://www.kommers.se/In-English/ Publications/2014/Making-Green-Trade-Happen/ (15.11.2019).

Kuźnar, A. [2017], Międzynarodowy handel produktami wiedzy, SGH Publishing House, Warsaw. Kuźnar, A. [2007], Ustugi w handlu międzynarodowym, Wydawnictwo Adam Marszałek, Toruń. Kuźnar, A. [2019], The Fourth Industrial Revolution and Its impact on Global Economy, in: A.M. Kowalski, M.A. Weresa (eds.), Poland. Competitiveness Report 2019. International Competitiveness in the Context of Development of Industry 4.0, SGH Publishing House, Warsaw.

Kuźnar, A., Żukowska, J. [2019], Rola cyfryzacji i nowoczesnych technologii w podnoszeniu innowacyjności krajów Europy Środkowo-Wschodniej, in: M. Strojny (ed.), Europa Środkowo-Wschodnia wobec globalnych trendów: gospodarka, społeczeństwo i biznes, SGH Publishing House, Warsaw. 
Levitt, T. [1976], The Industrialization of Service, Harvard Business Review, https://hbr. org/1976/09/the-industrialization-of-service (25.10.2019).

Melitz, M.J. [2003], The impact of trade on intra-industry reallocations and aggregate industry productivity, "Econometrica", No. 71, Vol. 6, pp. 1695-1725.

Paliński, M. (2016), Przyszłość pracy. Między „uberyzacją a automatyzacja, DeLab, Warsaw, http://www.delab.uw.edu.pl/wp-content/uploads/2016/10/przyszlosc_pracy.pdf (25.10.2019).

Rehse, O., Hoffmann, S., Kosanke, Ch. [2016], Tapping into the transformative power of Service 4.0, The Boston Consulting Group, https://www.bcg.com/d/press/26September2016-Tappinginto-Transformative-Power-of-Service-44564 (15.11.2019).

TISMOS [2019], Trade in Services data by mode of supply, WTO, https://www.wto.org/english/ res_e/statis_e/trade_datasets_e.htm\#TISMOS (30.10.2019).

TiVA [2018], Trade in Value Added Database, https://stats.oecd.org/ (30.10.2019).

UNCTAD [2015], International Trade in ICT Services and ICT-Enabled Services. Proposed Indicators from the Partnership on Measuring ICT for Development, Geneva, https://unctad.org/ en/PublicationsLibrary/tn_unctad_ict4d03_en.pdf (30.11.2019).

UNCTAD [2017], Information Economy Report 2017: Digitalization, Trade and Development, Geneva.

WDI [2019], World Development Indicators, World Bank, https://databank.worldbank.org/ source/world-development-indicators (18.11.2019).

Wettstein, S. et al. [2019], A global trade in services data set by sector and by mode of supply (TISMOS), WTO, https://www.wto.org/english/res_e/statis_e/daily_update_e/Tismos_ methodology.pdf (30.10.2019).

Wróbel, A. [2009], Międzynarodowa wymiana usług, Wydawnictwo Naukowe Scholar, Warsaw. WTO Data [2019], https://data.wto.org/ (30.10.2019).

WTO [2019a], World Trade Report 2019. The future of services trade, Geneva.

WTO [2019b], Global Value Chain Development Report 2019. Technological Innovation, Supply Chain Trade, and Workers in a Globalized World, Geneva. 

Chapter 13

\section{Service Sector Development Directions and Barriers in Poland}

Arkadiusz Michał Kowalski, Marta Mackiewicz, Marzenna Anna Weresa

\subsection{Introduction}

Innovations in the service sector are fundamentally different from those implemented in the industrial sector. While innovations by industrial companies are most often understood as the introduction of a new or improved product, the special feature of innovation in the service sector is generally its intangible nature. Traditionally, innovation has been identified primarily with industrial products, but now, due to the increasing importance of the service sector in the global economy, innovation is seen as a key factor in international competitiveness. The purpose of this chapter is to present the state of play in the development of the service sector in Poland visà-vis the European Union, to assess its innovativeness and to analyze the barriers that limit the innovation performance of companies in the service sector. The considerations presented concern, in particular, knowledge-intensive services, including knowledge-intensive business services, which play an important role in the economy by involving high-quality labor resources and supporting the development of other industries in the manufacturing and service sectors.

\subsection{Servitization of Highly Developed Economies and Development Dynamics of the Service Sector in Poland}

With socio-economic development, the importance of the service sector increases, reflecting the long-term evolution of the GDP formation structure, which consists in the transition of economies through successive stages [Lipowski, 1999]:

1) deagrarianization and industrialization, i.e. the reduction of the share of agriculture in favor of industry; 
2) stabilization of the industrial sector's GDP share and subsequent deindustrialization, i.e., the displacement of industry by more dynamically developing economic sectors;

3) servitization, i.e., increasing the share of the service sector.

The concept is an expansion of an earlier theory proposed by Rostow [1971], who identified five stages of development which occur in all countries around the world:

1) the traditional economy, which is characterized by subsistence agriculture and industry based on simple reproduction;

2) the preconditions for take-off through the development of trade, industry, new technology, and institutional structures;

3) the take-off, which can be driven by scientific discoveries and technological revolution;

4) the drive to maturity, characterized by the dominance of heavy industry;

5) the age of mass consumption.

According to Porter, Rostow's classification is characterized by a high level of generality and concerns stages of economic development in historical sense [Porter, 1990, p. 456]. In Porter's view, national economies undergo four stages of competitiveness development, representing successive stages in the economic growth process, which include:

1) factor-driven competitiveness,

2) investment- driven competitiveness,

3) innovation-driven competitiveness,

4) wealth-driven competitiveness.

This division stems from the assumption that at different stages of development of the economy different factors have the greatest impact on how quickly it develops and whether it is a sustainable process. Each of these phases involves the development of different sectors of the economy in which enterprises from a given country can compete effectively in the global market. Porter's concept shows that the development of the economy means transferring comparative advantages over time from labor-intensive and raw material-intensive production to capital-intensive production, and then to knowledge-intensive production, characterized by a high level of innovation and technological advancement. This process illustrates the path of economic development consisting of stages in which the economy is successively based on:

1) resources and raw materials,

2) investment and productivity,

3) knowledge and innovation.

The heritage of the centrally planned economy in Poland is not only the development gap separating it from the Western European countries, measured by the size 
of GDP per capita, but also the marginalization of service activities, characteristic of the economy of scarcity. This state is reflected, among other aspects, in employment in different sectors of the economy. The long-term dynamics of change in employment share of individual sectors of the Polish economy against vis-à-vis the EU average is shown in Figure 13.1.

Figure 13.1. Employment share of individual sectors of the Polish economy vis-à-vis the EU average in 1995-2018 (in \%)

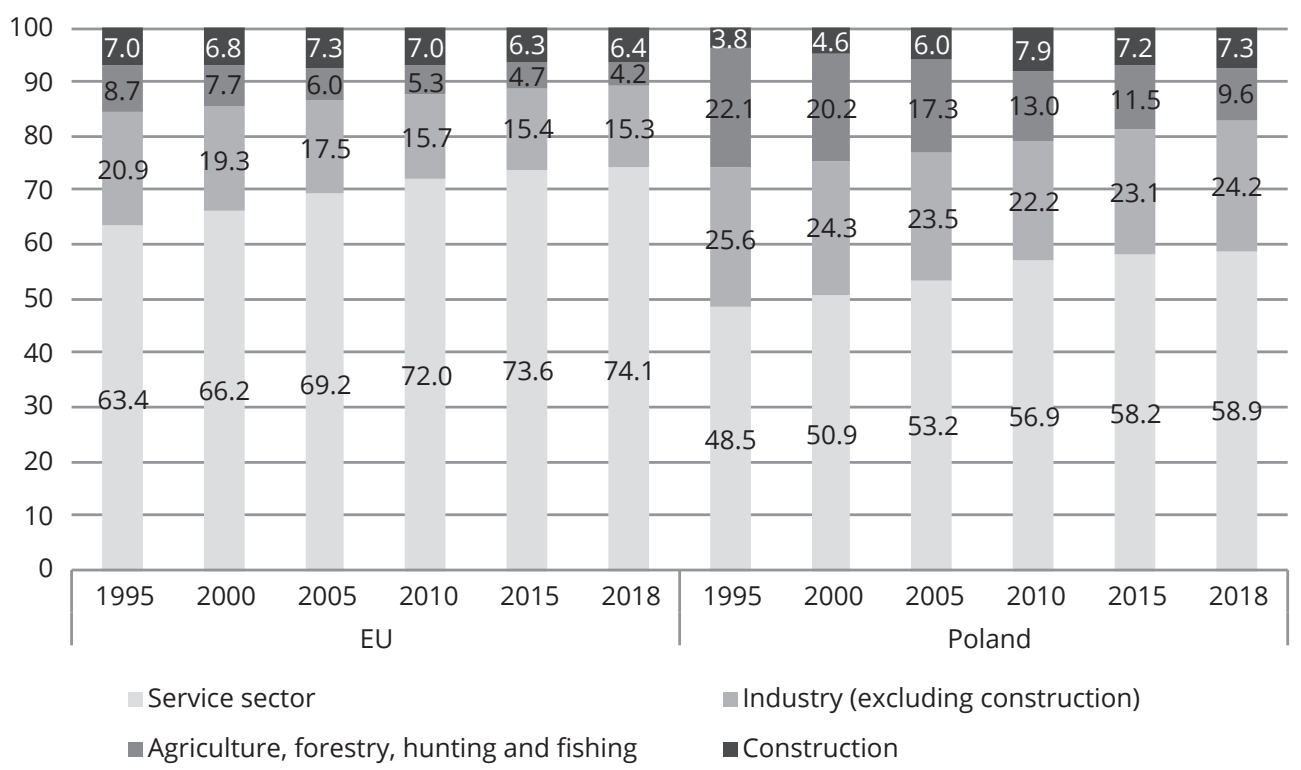

Source: Own calculations based on Eurostat data [nama_10_a10_e] (27.02.2020).

The share of the service sector in the structure of the Polish economy increased over the analyzed period from $48.5 \%$ in 1995 to $58.9 \%$ in 2018 , but it always remained below the EU average (64.4\% in 1995 and 74.1\% in 2018, respectively). According to Bell's concept [1974], development of services is accompanied by changes in the structure of the service sector, involving the transition from simple services to services requiring higher skills and based on high technologies. Decomposition of data on employment share in individual service industries is shown in Figures 13.2 (for Poland) and 13.3 (for the EU).

According to data presented in Figures 13.2-13.3, the following hold the greatest employment share in the service sector: wholesale and retail trade, accommodation and food service activities (39\% of employment in the service sector in Poland compared to $33 \%$ in the EU) and public administration and defense; education; human health and social work activities (35\% of employment in the service sector in Poland 
compared to $32 \%$ in the EU). Long-term trends in employment in individual types of services are shown in Figure 13.4.

\section{Figure 13.2. Employment share of individual service industries in total employment} in the service sector in Poland in 2018

Arts, entertainment and recreation;

other service activities; households as employers;

exterritorial organizations and bodies and defense; education, human health and social work activities

Professional, scientific and technical activities; administrative and support service activities

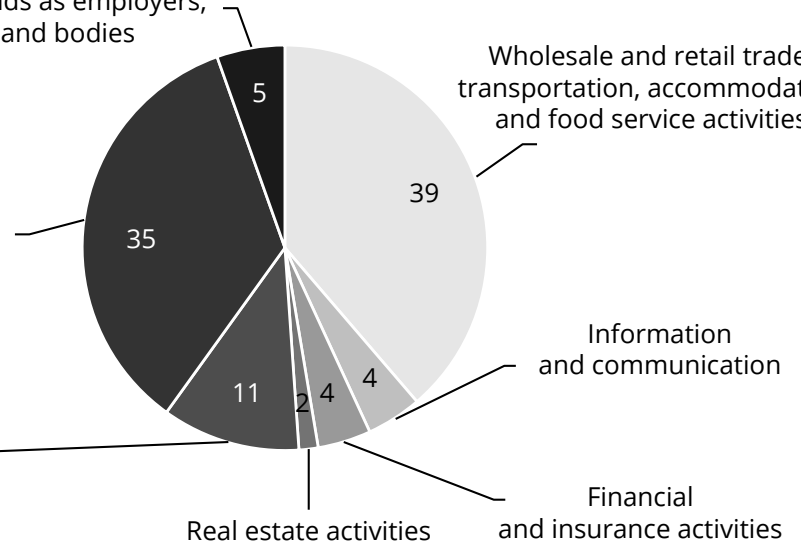

Source: Ibidem.

Figure 13.3. Employment share of individual service industries in total employment in the service sector in the EU in 2018

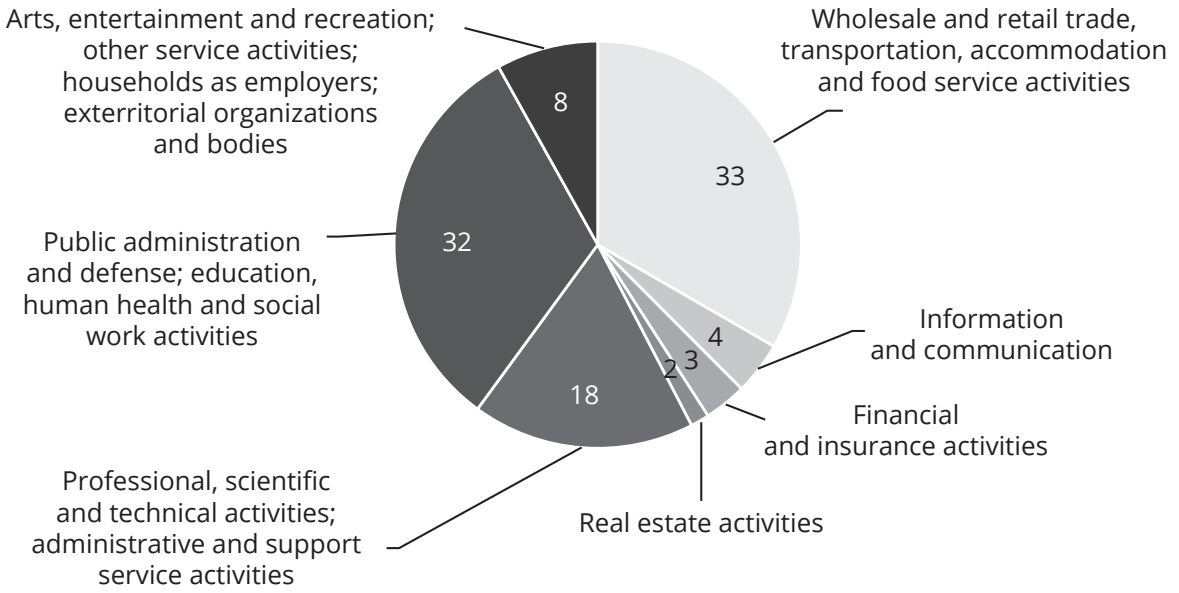

Source: Ibidem 
The data presented in Figure 13.4 show that the development of the service sector in Poland is accompanied by simultaneous shifts in employment distribution in this area. In the period under analysis, the steepest increase in employment concerned professional, scientific and technical activities along with administrative and support service activities (from $2.8 \%$ in 1995 to $6.5 \%$ in 2018) and in information and communication activities (from 1.1\% in 1995 to $2.6 \%$ in 2018). The fastest-growing types of services are largely classified as knowledge-intensive services, which are analyzed in the next sub-chapter.

Figure 13.4. Employment share of individual service industries in total employment in the Polish economy vis-à-vis the EU average in 1995-2018

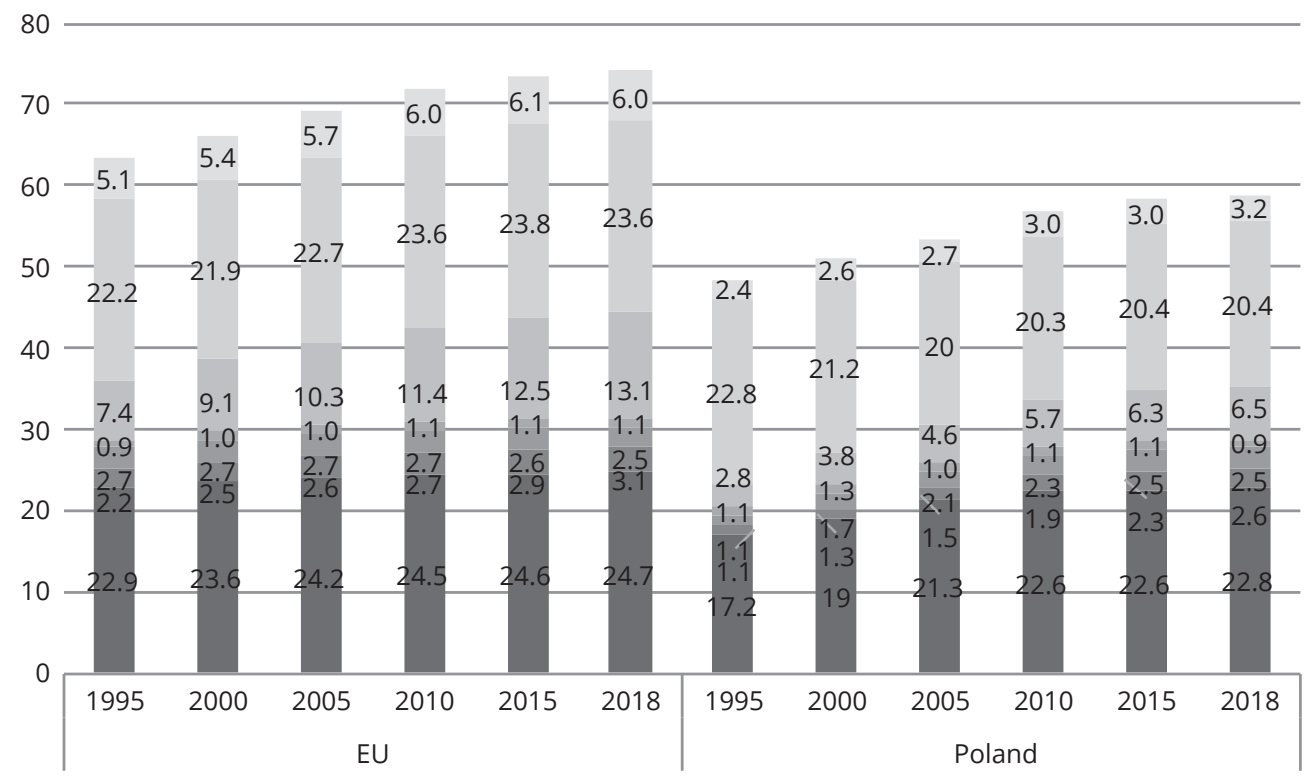

\footnotetext{
Arts, entertainment and recreation; other service activities; households as employers; exterritorial organizations and bodies

- Public administration and defense; education, human health and social work activities

- Professional, scientific and technical activities; administrative and support service activities

- Real estate activities

- Financial and insurance activities

- Information and communication

Wholesale and retail trade, transportation, accommodation and food service activities
}

Source: Ibidem. 


\subsection{Development of the Knowledge-Intensive Service Sector in Poland, including Knowledge-Intensive Business Services}

While the expansion of the service sector is seen to unfold with economic development, it is the development of specific types of services, and not of the whole sector, that plays a key role for the competitiveness of the economy. The developments seen in the contemporary global economy are indicative of a growing importance of knowledge-intensive services, in particular knowledge-intensive business services which engage high-quality labor resources, supporting the development of other industries in the manufacturing and service sectors. Table 13.1 presents employment data for selected knowledge-intensive service industries, with a particular focus on those classified as knowledge-intensive business services.

Table 13.1. Employment in selected knowledge-intensive service industries in Poland in 2010 and 2017

\begin{tabular}{|c|c|c|c|c|c|}
\hline Category & $\begin{array}{l}\text { PKD } \\
\text { division }\end{array}$ & Name of PKD division & 2010 & 2017 & $\begin{array}{l}\text { Change, } \\
2010=100\end{array}$ \\
\hline \multirow{9}{*}{$\begin{array}{l}\text { Knowledge-based } \\
\text { market services } \\
\text { (excluding } \\
\text { financial and } \\
\text { high-tech } \\
\text { services) }\end{array}$} & 50 & water transport & - & 2,406 & - \\
\hline & 51 & air transport & 5,539 & 4,197 & 76 \\
\hline & $69 *$ & $\begin{array}{l}\text { legal and accounting activities; tax } \\
\text { consultancy }\end{array}$ & 86,343 & 122,372 & 142 \\
\hline & $70 *$ & $\begin{array}{l}\text { activities of head offices; management } \\
\text { consultancy activities }\end{array}$ & 49,247 & 72,302 & 147 \\
\hline & $71 *$ & $\begin{array}{l}\text { architectural and engineering activities; } \\
\text { technical testing and analysis }\end{array}$ & 72,044 & 75,883 & 105 \\
\hline & $73 *$ & $\begin{array}{l}\text { advertising, market research and public } \\
\text { opinion polling }\end{array}$ & 40,892 & 45,599 & 112 \\
\hline & $74^{*}$ & $\begin{array}{l}\text { other professional, scientific and } \\
\text { technical activities }\end{array}$ & 6,056 & 11,808 & 195 \\
\hline & 78 & employment activities & 79,017 & 183,158 & 232 \\
\hline & 80 & security and investigation activities & 141,626 & 127,362 & 90 \\
\hline \multirow{6}{*}{$\begin{array}{l}\text { High-tech } \\
\text { services }\end{array}$} & 59 & $\begin{array}{l}\text { motion picture and sound recording } \\
\text { activities }\end{array}$ & 6,528 & 6,310 & 97 \\
\hline & 60 & programming and broadcasting activities & 15,549 & 16,165 & 104 \\
\hline & 61 & telecommunications & 56,110 & 49,621 & 88 \\
\hline & $62^{*}$ & computer programming and consultancy & 60,023 & 133,350 & 222 \\
\hline & $63^{*}$ & information service activities & 16,674 & 32,529 & 195 \\
\hline & 72 & scientific research and development & 6,056 & 11,808 & 195 \\
\hline
\end{tabular}




\begin{tabular}{|c|c|c|c|c|c|}
\hline Category & $\begin{array}{l}\text { PKD } \\
\text { division }\end{array}$ & Name of PKD division & 2010 & 2017 & $\begin{array}{l}\text { Change, } \\
2010=100\end{array}$ \\
\hline $\begin{array}{l}\text { Knowledge-based } \\
\text { financial services }\end{array}$ & $64-66$ & $\begin{array}{l}\text { financial and insurance activities } \\
\text { (Section K) }\end{array}$ & - & 164,788 & - \\
\hline \multirow{2}{*}{$\begin{array}{l}\text { Other knowledge- } \\
\text { based services }\end{array}$} & 58 & publishing activities & 43,519 & 33,312 & 77 \\
\hline & 75 & veterinary activities & 3,845 & 5,336 & 139 \\
\hline
\end{tabular}

Source: Own calculations based on Eurostat data, https://ec.europa.eu/eurostat/data/database (access: 2020.02.25). The mark (*) indicates industries that are generally classified as knowledge-intensive business services.

As noted in Chapter 1, the literature and documents of international organizations provide a precise classification of industries considered as knowledge-intensive services, but in the absence of a uniform approach as to which industries should be classified as knowledge-intensive business services, the assignment of such industries in the above list was made on the basis of a literature review. According to the European nomenclature, industries classified as knowledge-intensive business services can be divided into [Samul, 2016]:

- IT services (e.g., computer programming and consultancy, information service activities),

- technical services (e.g., architecture and engineering activities, technical testing and analysis),

- professional services (e.g., legal and accounting activities; tax consultancy).

The level and dynamics of employment in industries classified as knowledge-intensive business services in Poland in 2010 and 2017 are shown in Figure 13.5.

According to the data from Figure 13.5, the largest and fastest-growing industry classified among knowledge-intensive business services in Poland is computer programming and consultancy, for which the highest increase in employment was recorded during the period under study. This observation confirms a fast growth of the information and communication technology (ICT) sector, which is of an increasing importance in terms international competitiveness, driving the development of innovations in many areas, thereby contributing to the creation of new solutions in various areas of economic and social life. A successful development of the ICT industry in Poland is strengthened by widely available human resources - every year, about 15,000 IT graduates enter the labor market. It is also a highly forward-looking sector, as demand for skilled IT personnel keeps growing, which reflects an ongoing expansion of Polish enterprises and a dynamic development of outsourcing and shared service centers. Nevertheless, the labor market remains highly competitive in this industry, which ensures a good quality of workforce, as the average wage is much higher than the national average [Kowalski, 2016]. 
Figure 13.5. Employment distribution in industries classified as knowledge-intensive business services in Poland in 2010 and 2017 (in \%)

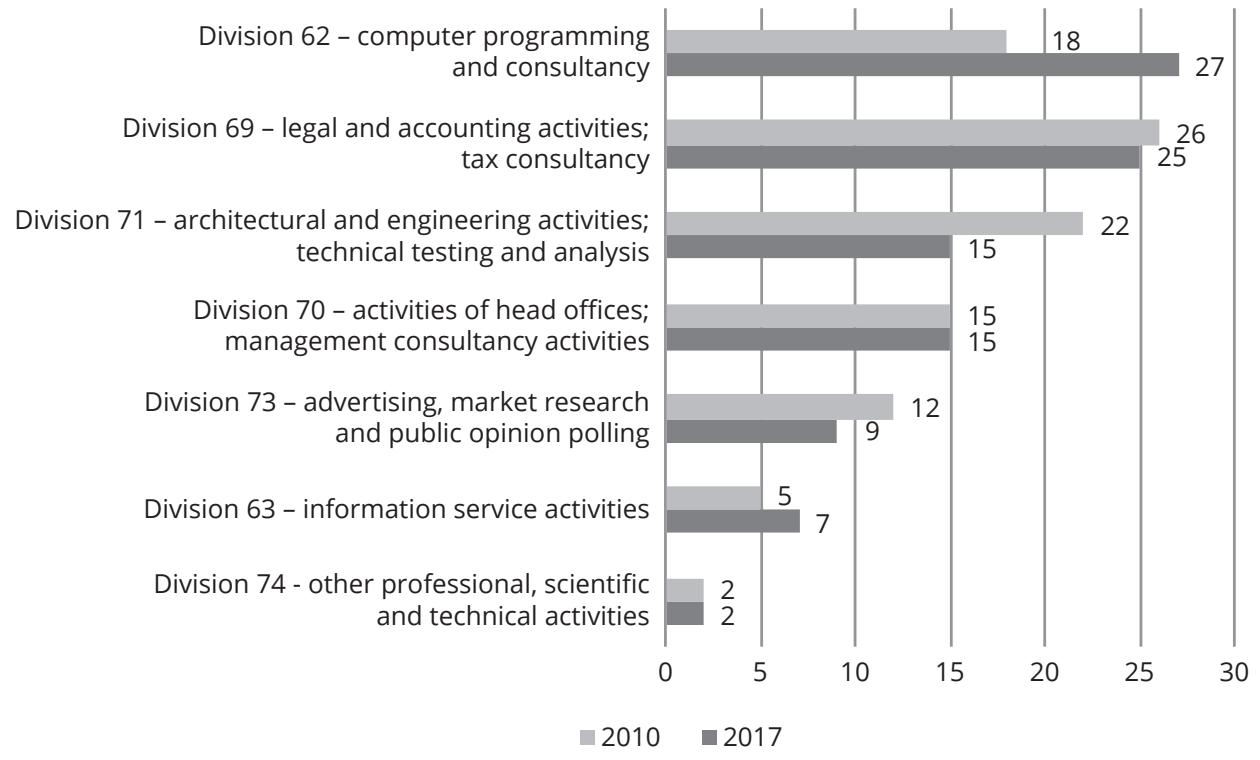

Source: Own calculations based on Eurostat data, https://ec.europa.eu/eurostat/data/database (access: 2020.02.20).

\subsection{Innovativeness of Service Industries in Poland}

The study on the innovativeness of service industries in Poland was conducted with the use of data provided by the Polish Agency for Enterprise Development (PARP). The data come from the first (2018) and second (2019) edition of the questionnaire survey Monitoring of Innovativeness of Polish Enterprises. The surveys were carried out using the computer assisted personal interview (CAPI) method on a national representative sample for a population of 1,327 firms.

The purpose of the study, in which the ordered logit model has been used, is to determine the innovativeness of service industries in Poland. The model estimation results are presented in Table 13.2. The analysis concerned enterprises' replies to the question on whether they systematically pursue innovation activities. The variable was coded as follows:

- the value 0 means systematic implementation of innovations in business,

- the value 1 means ad hoc activity (if need arises),

- the value 2 means no activity. 
Thus, negative values of the model parameters represent a more innovative approach of the enterprise.

Table 13.2. Results of an ordered logit model concerning the innovativeness of service industries in Poland

\begin{tabular}{|c|c|c|c|c|c|c|}
\hline \multicolumn{7}{|c|}{ Question: Does the firm engage in innovative activities ( $0=$ systematically, $1=a d$ hoc, $2=$ never $)$} \\
\hline & coefficient & $\begin{array}{l}\text { standard } \\
\text { deviation }\end{array}$ & Z-statistics & $P>|z|$ & \multicolumn{2}{|c|}{$\begin{array}{c}\text { confidence } \\
\text { intervals }(95 \%)\end{array}$} \\
\hline \multicolumn{7}{|l|}{ Industries } \\
\hline $\begin{array}{l}\text { knowledge-intensive services excluding } \\
\text { knowledge-intensive business services }\end{array}$ & -0.74 & 0.17 & -4.32 & 0.00 & -1.07 & -0.40 \\
\hline Knowledge-intensive business services & -0.55 & 0.19 & -2.90 & 0.00 & -0.92 & -0.18 \\
\hline \multicolumn{7}{|c|}{ Employment (reference level: 1-9 employees) } \\
\hline $10-49$ & -0.76 & 0.23 & -3.28 & 0.00 & -1.21 & -0.30 \\
\hline $50-249$ & -0.63 & 0.23 & -2.77 & 0.01 & -1.07 & -0.18 \\
\hline $250+$ & -1.17 & 0.25 & -4.74 & 0.00 & -1.65 & -0.69 \\
\hline \multicolumn{7}{|l|}{ Scale of activity (reference level: local) } \\
\hline Regional & -0.43 & 0.18 & -2.46 & 0.01 & -0.78 & -0.09 \\
\hline National & -0.82 & 0.21 & -3.99 & 0.00 & -1.23 & -0.42 \\
\hline European & -0.38 & 0.35 & -1.10 & 0.27 & -1.07 & 0.30 \\
\hline Global & -1.51 & 0.74 & -2.05 & 0.04 & -2.95 & -0.07 \\
\hline \multicolumn{7}{|l|}{ Other variables } \\
\hline Firm with foreign equity ( 1 = YES) & -0.14 & 0.25 & -0.57 & 0.57 & -0.63 & 0.35 \\
\hline $\begin{array}{l}\text { Innovations in previous years (2013- } \\
2015,1=\text { YES) }\end{array}$ & -1.26 & 0.16 & -8.05 & 0.00 & -1.56 & -0.95 \\
\hline Year of firm establishment & -0.01 & 0.01 & -1.94 & 0.05 & -0.02 & 0.00 \\
\hline \multicolumn{7}{|l|}{ Diagnostic data } \\
\hline Number of observations & 872 & & & & & \\
\hline LR chi²(12) statistics & 191.42 & & & & & \\
\hline Prob > chi ${ }^{2}$ & 0.00 & & & & & \\
\hline Pseudo R2 & $11.7 \%$ & & & & & \\
\hline Likelihood logarithm & -723.39 & & & & & \\
\hline
\end{tabular}

Source: Own calculations based on PARP [2019] data.

The results of this survey presented indicate that enterprises in knowledge-intensive service industries innovate more often than other service entities. However, a stronger effect was achieved for enterprises operating in non-business knowledge-intensive service industries. The analysis of the so-called odds ratio suggests an almost 2.1 higher frequency of the variable taking the value of 0 or 1 compared to identical entities in traditional service industries. A similar effect is also evident in the case of 
knowledge-intensive business services, although it is of a weaker nature - in this case the ratio is 1.73 .

The propensity to innovate increases gradually with the size of the company. The largest entities employing more than 250 people are 3.2 times more likely to declare their activities innovative than micro-enterprises. For medium-sized (10-49 employees) and large (50-249) companies, this ratio is close to 2 . Another determinant of systematic innovation is the geographical scope of activity. Global companies clearly stand out in this respect - the chances of them innovating are 4.5 times higher than for local firms. For nationwide companies, this ratio is 2.3 and for regional and pan-European companies 1.5. It should be noted that for firms producing for the EU market, this parameter is statistically insignificant, which may be due to the fact that some business entities operators forming the supply chain do not find it necessary to modify the product manufactured.

Systematic or irregular innovation is also more likely for firms that have historically implemented improvements in earlier years. The odds ratio in this case is 3.5. The last factor to be taken into account in the analysis is the firm's year of establishment. Younger enterprises are more likely to engage in innovation activities, but this effect is relatively small. The study shows that the variables that represent the membership of foreign corporate groups or having a foreign owner are not relevant.

\subsection{Innovation Barriers in Services, including Knowledge-Intensive Services in Poland}

So far, innovation policy has mainly focused on the manufacturing sector. Problems and barriers to innovation development in the service sector have similar causes to those faced by firms in the industrial sector. What distinguishes the service sector from other industries is the scale and scope of these problems. In the service sector, it is more difficult to achieve economies of scale, as there are barriers to mass sales of services, in particular outside the country.

In the Monitoring of Innovativeness of Polish Enterprises study [Kania et al., 2019] in response to a question about barriers to innovation development, service firms first mentioned keen competition in the industry, followed by insufficient resources of workers with appropriate skills, and, in third place, administrative burdens and bureaucracy. ${ }^{1}$ The entrepreneurs who participated in the study assessed the importance of

1 The Monitoring of Innovativeness of Polish Enterprises report (Monitoring innowacyjności polskich przedsiębiorstw. Wyniki II edycji badania - 2019) was commissioned by the Polish Agency for Enterprise Development (PARP). The survey was conducted in 2019 on a representative group of enterprises. The 
the different barriers on a five-step scale, where "5" means key importance and " 1 " indicates that the barrier of no importance (Figure 13.6).

Figure 13.6. Barriers to the development of innovation activities in the service sector (number of enterprises pointing to onerousness of respective barriers on 1-5 scale, $\mathrm{N}=391$ )

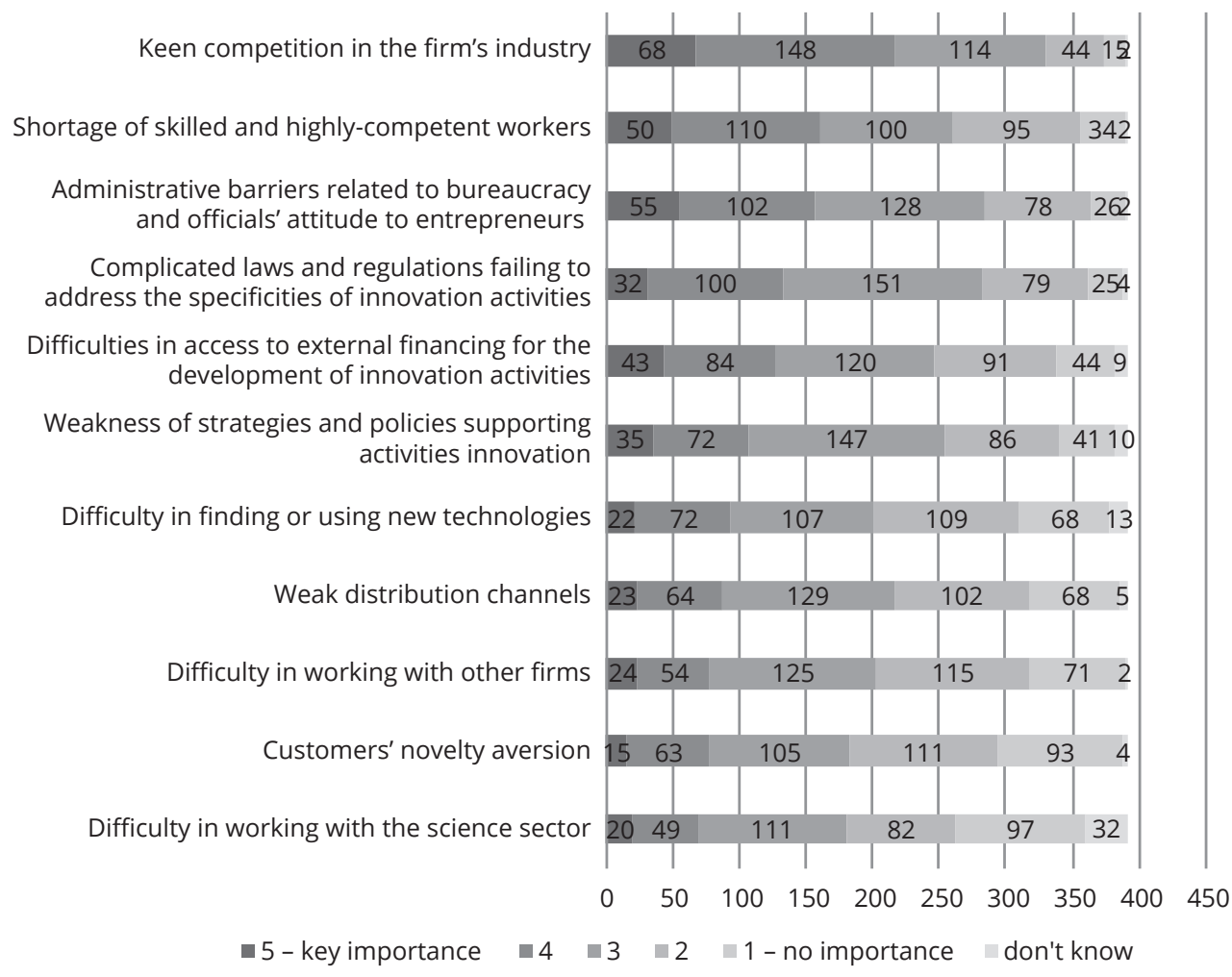

Source: Own study based on PARP data [2019].

As can be seen in Figure 13.6, the greatest barrier is keen competition which has increased significantly in the service sector over the last decade. Regulatory reform of the transport, communications, finance and certain business services markets, combined with a reduction of international barriers to trade and investment in services, have resulted in better accessibility of markets for certain services that were previously protected from competition.

survey results should be treated with caution, however, due to a limited number of firms in the knowledge-intensive service sector. 
Respondents' responses indicate that keen competition is a bigger problem for service enterprises in general than for firms operating in the knowledge-intensive service sector (Table 13.3). This conclusion is intuitive - the simpler the services, the greater the competition.

In addition to the barriers indicated in Figure 13.6, related to limited access to suitably qualified workers, the entrepreneurs participating in the survey also pointed to difficulties in recruiting workers from abroad due to a difficult and lengthy procedure.

Table 13.3. Barriers considered important and highly important by enterprises in the services and knowledge-intensive service sectors (in \%)

\begin{tabular}{|c|c|c|}
\hline Barriers & $\begin{array}{l}\text { Total } \\
\text { services }\end{array}$ & $\begin{array}{l}\text { Knowledge-intensive } \\
\text { services }\end{array}$ \\
\hline \multicolumn{3}{|l|}{ Cost-related barriers } \\
\hline $\begin{array}{l}\text { Difficulties in access to external financing for the development of } \\
\text { innovation activities }\end{array}$ & 32.5 & 31.6 \\
\hline \multicolumn{3}{|l|}{ Knowledge-related barriers } \\
\hline Difficulty in working with the science sector & 17.6 & 14.5 \\
\hline Difficulty in finding or using new technologies & 24 & 29.9 \\
\hline Shortage of skilled and highly-competent workers & 40.9 & 39.3 \\
\hline \multicolumn{3}{|l|}{ Market-related barriers } \\
\hline Customers' novelty aversion & 19.9 & 18.8 \\
\hline Difficulty in working with other firms & 19.9 & 20.5 \\
\hline Weak distribution channels & 22.3 & 17.9 \\
\hline Keen competition in the firm's industry & 55.2 & 48.7 \\
\hline \multicolumn{3}{|c|}{ Administrative and regulatory barriers } \\
\hline Weakness of strategies and policies supporting innovation activities & 27.4 & 26.5 \\
\hline $\begin{array}{l}\text { Complicated laws and regulations failing to address the specificities } \\
\text { of innovation activities }\end{array}$ & 33.8 & 30.8 \\
\hline $\begin{array}{l}\text { Administrative barriers related to bureaucracy and officials' attitude } \\
\text { to entrepreneurs }\end{array}$ & 40.2 & 33.3 \\
\hline
\end{tabular}

Source: Own study based on PARP data [2019].

It is worth noting that, among the barriers identified, access to finance was ranked only fifth - about one-third of the respondents considered it to be an important or highly important barrier, with slightly more enterprises not seeing this as a barrier to increasing the level of innovation. Nevertheless, innovation financing remains an important barrier for firms operating in the service sector, more so than for manufacturing firms. This is partly due to the fact that entities operating in certain service industries, such as business services, are quite small, which usually means more limited access to market financing. 
Figure 13.7. Reasons for which the firm did not take measures to implement innovations in 2016-2018

Service sector enterprises

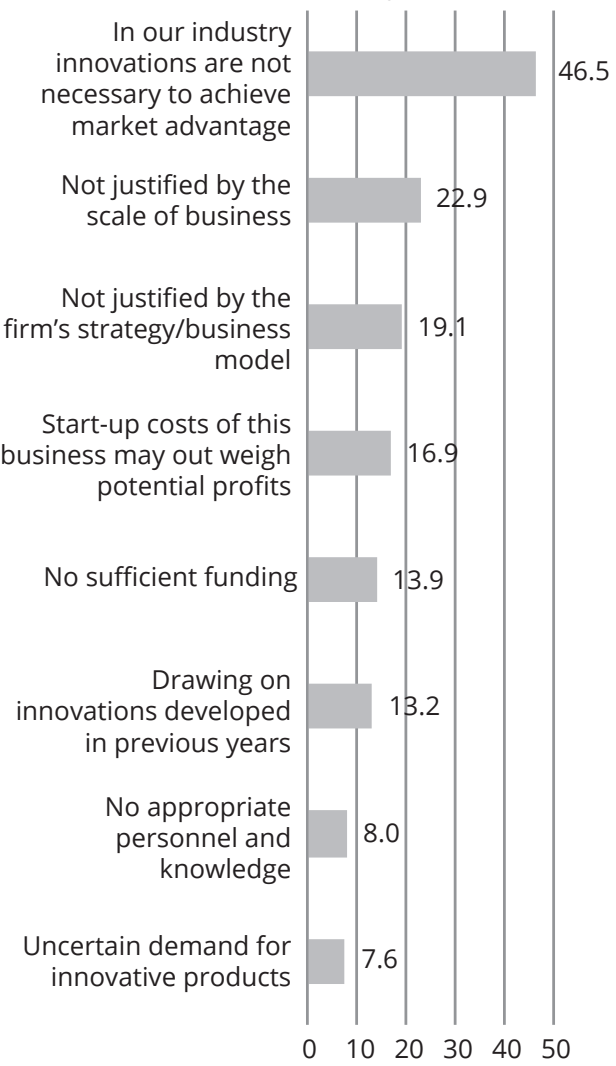

Knowledge-intensive service sector enterprises

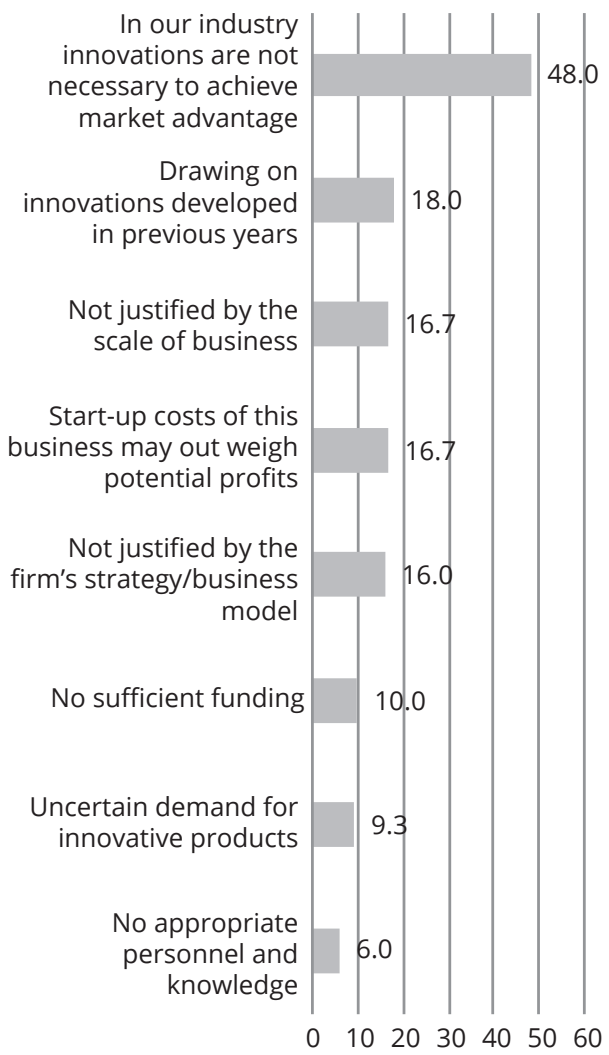

Source: Own study based on PARP data [2019] - services: $N=538$, knowledge-intensive services: $N=150$.

The results above differ slightly when enterprises of the knowledge-intensive service sector are taken into account. It should be noted that for all these barriers, the proportion of respondents who considered a given barrier to be highly important is lower and more entrepreneurs considered the individual barriers to be of low importance. This may mean that firms operating in the knowledge-intensive service sector have better adaptability and find it easier to adjust to market conditions. On the other hand, as D'Este et al. [2008] noted, only firms that have experienced certain problems or barriers can consider them important. This was confirmed by the results of a study using data collected in the Community Innovation Survey (CIS) for the UK. This may suggest that firms operating in the knowledge-intensive service sector are not more innovative than other enterprises. 
The data provided in Table 13.3 show that firms in the knowledge-intensive service sector see access to new technologies as an important barrier to development. Firms that rely on knowledge and actually use new technologies see a bigger problem in finding and using them (because very often they face difficulties at this particular level).

Additional information is provided by an analysis of the reasons which the entrepreneurs surveyed have identified as underlying their non-engagement in innovation activities. Some of them can also be attributed to the groups of barriers listed in Table 13.3, such as the lack of sufficient financial resources or start-up costs outweighing potential profits, as well as to cost-related barriers (uncertain demand for innovative products) and market-related barriers.

Based on a comparison of responses from representatives of service sector enterprises and firms falling within the knowledge-intensive service sector, several hypotheses can be formulated that require further in-depth research:

1) the availability of funds for innovation activities is not an important problem in Poland currently, which marks a significant shift from the development barriers to innovation activities reported by the business community until a few years ago; 2) the reduction is the cost of doing business, which firms haven increasingly paying attention to as a result of regulatory changes introduced in recent years (increase in the minimum wage, increase in social security contributions, tax regulations requiring the employment of professional accounting services even in the case of a small scale of activity, etc.);

3) the percentage of responses "in our industry innovation is not necessary to achieve market advantage" indicates the need to be aware of the opportunities offered by innovation; a high proportion of these ratings may also be due to the fact that what entrepreneurs mean by "innovation" is disruptive change, being unaware that the definition of innovation includes the introduction of both new and significantly improved business products and processes [OECD/Eurostat, 2018].

Attention is drawn to a higher proportion of such ratings in the knowledge-intensive service sector than in the overall service sector. This may mean a lower propensity for innovation in the knowledge-intensive service sector. It is worth mentioning here a study carried out in the UK, comparing firms which are innovative in the service sector with non-innovative service firms. It showed that firms implementing innovations notice many more barriers to innovation, regardless of the type of changes being made. Similar results were obtained by analyzing the share of firms that rated these barriers as "highly important" [D'Este et al., 2008]. As noted above, knowledge-intensive service firms exhibit similar characteristics in this respect as non-innovative service firms. However, further in-depth research would be required to confirm this hypothesis. 
In addition, there are a number of barriers which are specific to a particular industry. For example, financial undertakings point to restrictions under personal data protection regulations. As a result of these rules, financial institutions (banks, FinTech sector) cannot take full advantage of modern technological solutions. This includes, for example, the collection and use of customer data and the use of cloud computing solutions. One of the main regulatory barriers to the development of the FinTech sector in Poland is the length and complexity of the Financial Supervision Commission's (KNF) authorization procedure for the provision of payment services. Outsourcing of services also involves significant difficulties. In KNF's view, banks take insufficient measures to effectively optimize the risk inherent in such contracts. A complicated licensing procedure is also a barrier. Small entities with limited resources point to difficulties in obtaining authorization to start business, which in many cases results in such business being taken up outside the country [Widawski et al., 2017].

\subsection{Supporting the Service Sector in Poland}

The innovation policy instruments available in Poland, addressing enterprises and aimed at improving the level of innovation do not take into account the specificities of the service sector. Among innovation-active enterprises, service enterprises receive support less often than manufacturing firms. Between 2015 and 2017, public financial support for innovation activities was granted to $22.1 \%$ of innovation-active industrial enterprises (compared to $23.5 \%$ in 2014-2016) and 17.9\% of service enterprises (compared to $18.3 \%$ ). The same applies to aid from national institutions - it was received more often by innovation-active industrial enterprises than service enterprises [GUS 2018]. A similar picture emerges from the analysis of data from the SL2014 database for monitoring projects financed by structural funds. Under the Smart Growth Operational Program, the largest program to support business innovation in 2014-2020, most agreements were signed with C-section enterprises $(4,985)$. It should be noted that the two service sections, which can be compared with industrial ones in terms of the number of signed co-financing agreements, in relation to the number of enterprises operating in the section concerned, are those classified as knowledge-intensive business services (Section $\mathrm{J}$ - information and communication, and Section $\mathrm{M}$ - professional, scientific and technical activities).

Although innovation policy is sector-neutral (service sector enterprises are neither preferred nor excluded), support instruments are in fact better suited to the needs of industrial sector enterprises. Service firms are becoming increasingly innovative, but industry continues to dominate in research and development. This is due, among 
other things, to the fact that non-technological innovations form a large proportion of innovations in the service sector. Innovations and the introduction of new technologies are usually linked to accompanying investments in training and skill development. As a result, service companies attach as much importance to investing in employee training as to investing in new technologies (although the focus can vary depending on the specificities of the industry concerned, e.g., medical services will be more dependent on new technologies than elderly care).

Figure 13.8. Percentage of enterprises that have received co-financing from the Smart Growth Operational Program in individual PKD sections in 2019 (in \%)

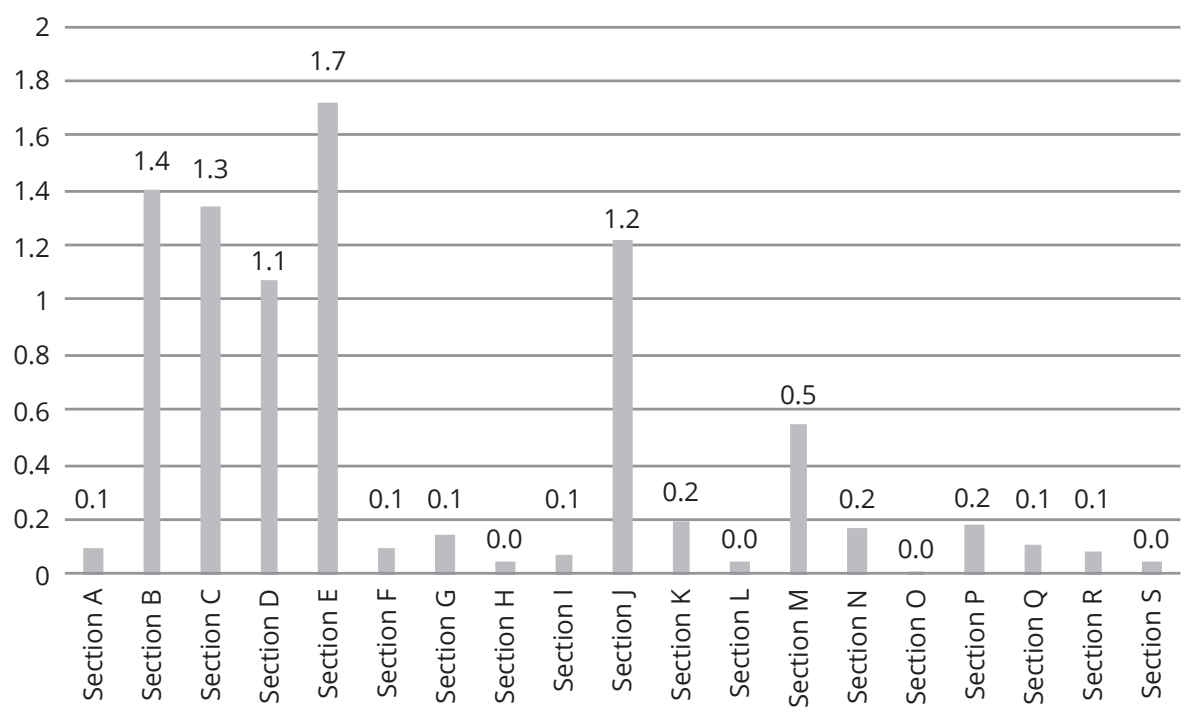

Source: Own calculations based on GUS data [2018] and SL2014 database [end of 2019].

Public R\&D expenditure, in particular basic research, usually does not take into account long-term needs relating to services (e.g., do not provide a better understanding of how technology should be implemented). More focus should be places in research financing on the needs of the service sector. In this context, it is important to involve service firms more widely in the creation of research agendas at national and regional level. This will make it possible to establish contacts with the science sector. Stronger links with public research institutions could improve the innovative capacity of service companies and adapt basic research to the needs of the service sector.

Given that service sector enterprises tend to be faced with non-technological innovations, instruments should be developed under which support is provided mainly to such solutions. 
As indicated above, regulatory barriers are a group of barriers to the development of innovation activities in the service sector. Already many years ago, the OECD [2005] recommended the development of a regulatory framework and technological solutions (such as certification and authentication) that could enable electronic business and digital services, e.g., in areas such as health, financial services, tourism, distribution or logistics, fostering a "security culture". However, efforts along these lines are still underway. Research in many OECD countries shows that privacy and security concerns remain among the main barriers to the use of ICT.

The introduction of solutions identified as necessary by representatives of fast-growing industries is also recommendable. FinTech firms, for example, anticipate the creation of an "IP Box", a regulatory arrangement that allows entrepreneurs to safely test new products without having to meet all regulatory requirements. Firms operating in this industry also point to the need for a regulatory arrangement that would enable them to test services in the market in order to analyze opportunities and related threats [Widawski et al.].

It should be noted that a number of innovation barriers identified by service enterprises may be reduced by networking. For example, networks that are emerging around new technologies (biotechnology, nanotechnology, new generations of ICT, etc.) could work more actively with service enterprises, which are often their main users or intermediaries between hardware suppliers and end users. The development of artificial intelligence will also lead to multiple applications in services or stimulate the emergence of new services. Service enterprises often function well in the environment of other firms, educational institutions, and research centers. Such conditions are also provided by clusters. Therefore, facilitating access to the service sector may be an important support for the service sector.

One of the important barriers seen by service sector enterprises is the shortage of skilled personnel. Of the service enterprises surveyed, $40 \%$ considered this barrier to be important or highly important. It is worth considering in this context the involvement of different actors in professional development and experience-based learning. The public sector may also involve service sector entities in the pursuit of public policy objectives, in particular in the areas of education, health, digitalization, circular economy and other areas, which should motivate companies to create new services.

Efforts towards improving innovation performance in in the service sector should also include incentives for the creation of courses and the exchange of professionals with the use of R\&D services and the management of service innovations. Tax allowances for service enterprises that improve innovation management this way may also be considered. 


\subsection{Conclusions}

With the socio-economic development of countries, the importance of the service sector is increasing, which is linked to the servitization of economies. This is also the case for the Polish economy, where the GDP share of the service sector, although lower than the European Union average, increased from 48.5\% in 1995 to $58.9 \%$ in 2018. This increase was related most closely to information and communication services, and above all to knowledge-intensive business services relating to computer programming and consultancy. This observation is confirmed by the rapid development of information and communication technologies (ICT) in Poland. They are of particular significance in terms of international competitiveness by providing solutions that are important for the development of other socio-economic areas.

Service firms face a number of barriers to implementing innovations, some of which can be eliminated through well-chosen innovation policy instruments. Keen competition is the biggest obstacle mentioned by firms, followed by the limited availability of highly skilled workers. The regulatory environment is also a barrier. Public policies aimed at improving innovativeness in the service sector should therefore focus on issues related to education, vocational training, and enabling firms to invest in employee training and development, as well as the exchange of professionals, especially in the field of R\&D services.

\section{Bibliography}

Bell, D. [1974], The Coming of Post-Industrial Society, Harper Colophon Books, New York.

Czerwińska, E. [2003], Usługi w gospodarce polskiej, Kancelaria Sejmu, Biuro Studiów i Ekspertyz, Wydział Analiz Ekonomicznych i Społecznych, No. 991.

D'Este, P. et al. [2008], What hampers innovation? Evidence from the UK CIS4, SPRU Electronic Working Paper Series, No. 168.

GUS [2018], Działalność innowacyjna przedsiębiorstw w latach 2015-2018, Warsaw-Szczecin. Kania, I. et al. [2019], Monitoring innowacyjności polskich przedsiębiorstw. Wyniki II edycji badania-2019, PARP, Warsaw.

Kowalski, A.M. [2016], Poland, an emerging European ICT hub?, "Baltic Rim Economies", issue 4, p. 25.

Lipowski, A. [1999], Zmiany $w$ strukturze tworzenia PKB $w$ Polsce $w$ okresie transformacji 1990-1997/98. Analiza i ocena, "Ekonomista", No. 5, pp. 565-610.

OECD [2005], Growth in Services Fostering Employment, Productivity and Innovation, OECD, Paris. 
OECD/Eurostat [2018], Oslo Manual 2018: Guidelines for Collecting, Reporting and Using Data on Innovation, $4^{\text {th }}$ edition, The Measurement of Scientific, Technological and Innovation Activities, OECD Publishing, Paris/Luxembourg.

PARP [2019], Monitoring innowacyjności polskich przedsiębiorstw, survey study (unpublished). Porter, M.E., The Competitive Advantage of Nations, The Free Press, New York.

Rostow, W.W., Politics and the Stages of Growth, Cambridge.

Samul, J. [2016], Sektor ustug wiedzochłonnych $w$ Polsce na tle UE, "Kwartalnik Nauk o Przedsiębiorstwie", No. 4, pp. 95-101.

Widawski, P. et al. [2017], FinTech $w$ Polsce - bariery i szanse rozwoju, FinTech Poland, Obserwatorium.biz, Centrum Prawa Nowych Technologii Wydziału Prawa i Administracji Uniwersytetu Warszawskiego, http://fintechpoland.com/raport-fintech-w-polsce-bariery-i-szanse-rozwoju/ (27.11.2019). 

Chapter 14

\section{Innovativeness of Service Sector Enterprises in Poland}

Małgorzata Stefania Lewandowska

\subsection{Introduction}

Over the last few decades, the role of the service sector in generating the value added of the economy and in job creation has increased significantly. It turns out, however, that the classification of services and understanding of their specificities pose much greater a challenge than is the case with tangible goods - mainly because of the multitude of service categories identified. In this context, the objective of the chapter is to precisely define and classify services and to pinpoint their place in the economy.

Another important element of the considerations presented is the identification of the service areas in which innovations are being introduced. To this end, the results of empirical studies, mainly relating to Poland, will be cited, which are ultimately intended to present the author's classification of research areas for the service sector.

The third objective of the chapter is to demonstrate the innovation level of Polish service sector enterprises and to perform a comparative analysis of selected sections of knowledge-intensive services: information and communication services $(\mathrm{J})$, financial and insurance services $(\mathrm{J})$, and professional, scientific and technical services (M) vis-à-vis sectors in selected European countries. This will allow Poland's position in this respect to be identified, with a particular focus on two variables: the innovation budget and the level of cooperation in innovation activities.

The last objective of the chapter is to attempt to identify the reasons behind the moderate level of innovation witnessed so far among Polish service sector enterprises. 


\subsection{Services - Definition and Classification Adopted}

The issue of defining the concept of service has been raised in many publications. Initially, a service was defined as something other than a product, that is, by negation. A service was perceived as something complementary to business (Fisher 1939) ${ }^{1}$.

In this chapter, we assume that services are defined as "activities performed for business entities engaging in production activities, i.e. services for production purposes that do not directly create new tangible goods, and any activities performed for entities of the national economy and for the population, intended for individual, collective and society-wide consumption ${ }^{2 \prime}$ [PKWiU, 2015, p. 4].

The structure of individual product groups in PKWiU [2015] takes into account the basic classification criteria. For products, the following are taken into account in this case: 1) the criterion of manufacturing (industrial) origin by type of activity, 2) the raw material criterion, 3) the manufacturing technology criterion, 4) the product design criterion, 5) the criterion of destination; and for services: 1) the criterion of origin by type of activity and 2) the type of services provided [PKWiU 2015, p. 4]. In the case of services, the classification according to PKWiU [2015] concerns activities (which are the final outcomes of activities) of a service nature, performed by economic operators (organizational units) to other economic operators (organizational units) or to the public. Each service "should be included in an appropriate grouping according to its nature, irrespective of the PKD symbol under which the economic operator performing the service is classified in the national official register of entities of the national economy REGON" [PKWiU, 2015, p. 7]).

For the sake of consistency with the definition thus adopted, the classification of services was carried out according to Eurostat's proposal which is based directly on the groupings of the Statistical Classification of Economic Activities in the European Community (NACE) ${ }^{3}$, to which the division adopted in the Polish Classification of Products and Services (PKWiU) is closely related [PKWiU, 2015, p. 4].

\footnotetext{
1 An extensive overview of service definitions is presented, e.g., by Osiadacz [2015], pp. 16-24.

2 "The concept of services does not include activities related to the manufacture of products (including semi-products, components, parts, machining of components) from the firm's own materials, made to order for other entities of the national economy for production purposes or for resale, and it usually does not include the manufacture of products to order for individual consumers, from the contractor's own materials" [PKWiU 2015, p. 4].

3 NACE Rev. 2 classification is a binding unified system of statistical classification of economic activities for EU member states, effective since 2007. Statistically, the economic activities concerned are divided in NACE Rev. 2 into 21 sections. See Eurostat [2008], p. 47.
} 
As in the case of manufacturing, Eurostat divides services into knowledge-intensive sectors and less knowledge intensive sectors, within which further sub-groups are distinguished.

Sections: J, K, M, O belong in whole to the knowledge-intensive services group, while: G, I, L, N, S, T and U are classified in whole as less knowledge-intensive services. Sections $\mathrm{H}$ and $\mathrm{N}$ belong partly to both groups. A detailed breakdown of NACE sections into knowledge-intensive services and less knowledge-intensive services is provided in Table 14.1.

Table 14.1. Aggregation of services according to NACE Rev. 2 and PKWiU

\begin{tabular}{|c|c|}
\hline \multicolumn{2}{|r|}{ KNOWLEDGE INTENSIVE SERVICES (KIS) } \\
\hline PKWiU & Description \\
\hline $\mathrm{H}$ & TRANSPORTATION AND STORAGE (H49-H53) \\
\hline $\begin{array}{l}\mathrm{H} 50 \\
\mathrm{H} 51\end{array}$ & $\begin{array}{l}\text { water transport } \\
\text { air transport and space transport }\end{array}$ \\
\hline J & INFORMATION AND COMMUNICATION SERVICES (J58-J63) \\
\hline $\begin{array}{l}J 58 \\
J 59 \\
J 60 \\
\mathrm{~J} 61 \\
\mathrm{~J} 62 \\
\mathrm{~J} 63\end{array}$ & $\begin{array}{l}\text { publishing services } \\
\text { motion picture, video and television programme production, sound recording and music } \\
\text { publishing services } \\
\text { programming and broadcasting services } \\
\text { telecommunication services } \\
\text { computer programming, consultancy and related services } \\
\text { information services }\end{array}$ \\
\hline K & FINANCIAL AND INSURANCE ACTIVITIES (K64-K66) \\
\hline $\begin{array}{l}\text { K64 } \\
\text { K65 } \\
\text { K66 }\end{array}$ & $\begin{array}{l}\text { financial services, except insurance and pension funding } \\
\text { insurance, reinsurance and pension funding services, except compulsory social security } \\
\text { services auxiliary to financial services and insurance and pension funding }\end{array}$ \\
\hline M & OTHER PROFESSIONAL, SCIENTIFIC AND TECHNICAL ACTIVITIES (M69-M75) \\
\hline $\begin{array}{l}\text { M69 } \\
\text { M70 } \\
\text { M72 } \\
\text { M73 } \\
\text { M74 } \\
\text { M75 }\end{array}$ & $\begin{array}{l}\text { legal, accounting and tax consultancy services } \\
\text { services of head offices; management consultancy services } \\
\text { architectural and engineering services; technical testing and analysis services } \\
\text { scientific research and development services } \\
\text { advertising, market research and public opinion polling services } \\
\text { other professional, scientific and technical activities } \\
\text { veterinary services }\end{array}$ \\
\hline $\mathrm{N}$ & ADMINISTRATIVE AND SUPPORT SERVICES (N77-N82) \\
\hline N78 & employment services \\
\hline N80 & security and investigation services \\
\hline $\mathrm{O}$ & $\begin{array}{l}\text { PUBLIC ADMINISTRATION AND DEFENSE SERVICES; OBLIGATORY SOCIAL SECURITY SERVICES } \\
(\text { O84) }\end{array}$ \\
\hline$P$ & EDUCATION (P84) \\
\hline Q & HUMAN HEALTH AND SOCIAL WORK SERVICES (Q86-Q88) \\
\hline
\end{tabular}


cont. tab 14.1

\begin{tabular}{|c|c|}
\hline \multicolumn{2}{|r|}{ KNOWLEDGE INTENSIVE SERVICES (KIS) } \\
\hline PKWiU & Description \\
\hline $\mathrm{R}$ & ARTS, ENTERTAINMENT, SPORTS AND RECREATION SERVICES (R90-R93) \\
\hline $\begin{array}{l}\text { O84 } \\
\text { P85 } \\
\text { Q86 } \\
\text { Q87 } \\
\text { Q88 } \\
\text { R90 } \\
\text { R91 } \\
\text { R92 } \\
\text { R93 }\end{array}$ & $\begin{array}{l}\text { public administration and defense services; compulsory social security services } \\
\text { educational services } \\
\text { human health services } \\
\text { residential care services } \\
\text { social work services without accommodation } \\
\text { arts and entertainment services } \\
\text { libraries, archives, museums and other cultural activities } \\
\text { gambling and betting services } \\
\text { sports, amusement and recreation services }\end{array}$ \\
\hline \multicolumn{2}{|r|}{ LESS KNOWLEDGE INTENSIVE SERVICES - LKIS } \\
\hline G & WHOLESALE AND RETAIL TRADE REPAIR OF MOTOR VEHICLES AND MOTORCYCLES ( (G45-G47) \\
\hline $\begin{array}{l}\mathrm{G} 45 \\
\mathrm{G} 46 \\
\mathrm{G} 47\end{array}$ & $\begin{array}{l}\text { wholesale and retail trade and repair of motor vehicles } \\
\text { wholesale trade, except wholesale trade in motor vehicles } \\
\text { wholesale trade, except retail trade in motor vehicles }\end{array}$ \\
\hline $\mathrm{H}$ & TRANSPORTATION AND STORAGE (H49-H53) \\
\hline H49 & land and pipeline transport \\
\hline $\begin{array}{l}\mathrm{H} 52 \\
\mathrm{H} 53\end{array}$ & $\begin{array}{l}\text { warehousing and support services for transportation } \\
\text { postal and courier services }\end{array}$ \\
\hline I & ACCOMMODATION AND FOOD SERVICE ACTIVITIES (I55-I56) \\
\hline $\begin{array}{l}155 \\
156\end{array}$ & $\begin{array}{l}\text { accommodation services } \\
\text { food and beverage services }\end{array}$ \\
\hline $\mathrm{L}$ & REAL ESTATE SERVICES $\{$ L68) \\
\hline L68 & real estate services \\
\hline $\mathrm{N}$ & ADMINISTRATIVE AND SUPPORT SERVICES (N77-N82) \\
\hline N77 & rental and leasing \\
\hline N79 & Travel agency, tour operator and other reservation services \\
\hline N81 & services to buildings and landscape activities \\
\hline N82 & office administrative, office support and other business support services \\
\hline S & OTHER SERVICES (S94-S96) \\
\hline $\begin{array}{l}\text { S94 } \\
\text { S95 } \\
\text { S96 }\end{array}$ & $\begin{array}{l}\text { services provided by membership organizations } \\
\text { repair of computers and personal and household goods } \\
\text { SK24 - other personal services }\end{array}$ \\
\hline $\mathrm{T}$ & $\begin{array}{l}\text { HOUSEHOLD SERVICES; UNDIFFERENTIATED PRODUCTS AND SERVICES PRODUCED BY } \\
\text { PRIVATE HOUSEHOLDS FOR OWN USE (T97-T98) }\end{array}$ \\
\hline$U$ & SERVICES PROVIDED BY EXTERRITORIAL ORGANIZATIONS AND BODIES (U99) \\
\hline $\begin{array}{l}\text { T97 } \\
\text { T98 } \\
\text { U99 }\end{array}$ & $\begin{array}{l}\text { services provided by households as employers } \\
\text { undifferentiated goods and services produced by private households for own use } \\
\text { services provided by exterritorial organizations and bodies }\end{array}$ \\
\hline
\end{tabular}

Source: Compilation based on NACE Rev. 2, PKWiU [2015] and aggregation of services proposed by Eurostat. 


\subsection{Innovations in Services - Research Areas of Polish Researchers}

In recent years, many books have been published in Poland on the issue of services in the international dimension [Skórska, 2012; Kłosiński, 2011] and national dimension [Szczukocka, 2013], conditions of their development [Pluta-Olearnik and Wrona, 2014; Skins 2013; Ilnicki 2009; Skórska, 2013; Ilnicki, 2009; Dąbrowska 2008], relationships between the service sector and the level of employment [Węgrzyn, 2015], service management [Filipiak and Panasiuk (eds.), 2008] or containing characteristics of selected service sector industries, including in particular knowledge-intensive services [Wyszkowska-Kuna, 2016; Skins, 2012; Skórska, 2012]. In turn, innovations in services and related good practices are the subject of publications by Osiadacz [2012] and Dąbrowska [2011], published by PARP.

When reviewing articles on the service sector, the resources of the BazEkon database were used, containing papers published in economic journals and related science journals.

In the first stage of the study, the headword "services" was entered in the "title" field, and the headword "innovation in service" was entered in the "term" field. 784 publications have been identified in group dealing with broadly-defined services, while 186 articles concerned specifically innovation in services.

Looking at the results of the study, we can conclude that more than $90 \%$ of the works in both groups were published between 2000 and 2018, i.e. in the last dozen or so years. The first work, which contains the headword "services" in its title, was published in 1982. Figure 14.1 illustrates the trend towards the release of articles on innovation in services relative to publications on services in general.

The analysis of the data presented in this graph leads to several conclusions. Publications on services in general and publications on innovation in services, are seen to follow an upward trend in terms of the number of articles published, in particular between 2000 and 2018. Trendlines for both those issues show that publications covering both services in general and innovations in services follow an increasing trend, although this trend is not significantly strong and there are visible differences in the number of articles published over the past years.

The next step in the study was to separate the research areas of 186 studies on innovation in services. The observation period was first limited to 2015-2018 (including several works already published in 2019). The next step was a detailed analysis of the content of studies and the elimination of those whose subject matter did 
not directly concern innovation in services. As a result, the number of studies verified decreased to 55 .

Figure 14.1. The number of articles published in indexed journals in the BazEkon database on total services and innovation in services between 1982 and 2018

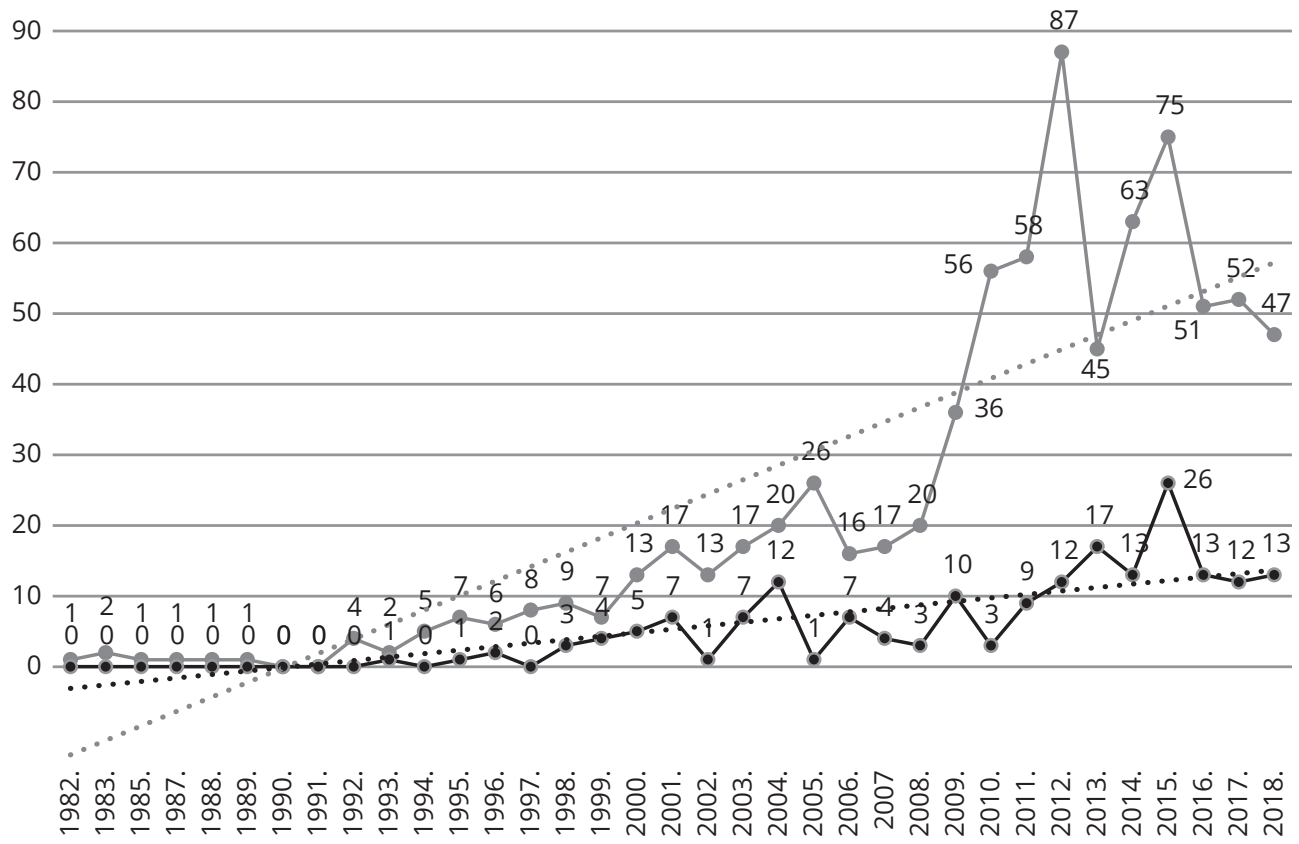

Source: Own study based on BazEkon data.

It was found that less than half of the publications were works containing the results of empirical studies. Using the "bibliographic coupling" method ${ }^{4}$, the sources of knowledge and data used by authors, the nature and type of information, the basis for inference and justification for the veracity of the research hypotheses adopted were identified. On the other hand, the nature of publications in which articles are published, as well as their location, determine the possibility of disseminating the conclusions and hypotheses contained in the articles and the degree of openness of journals to publications on innovation in services.

4 Bibliographic analysis may take into account the existence of "bibliographic coupling" in the set of references attached to the articles being compared, i.e. citing the same paper, co-citation, i.e. citation in the article being examined of literature items which contain, in turn, reference the same source; or it can combine both analytical methods. 
Table 14.2. Research areas presented in publications on innovation in services in BazEkon journals in 2015-2019

\begin{tabular}{|c|c|}
\hline Research area & Publications \\
\hline Defining innovation in services & Pichlak [2015]; Wosiek [2018] \\
\hline Trends in research on the service sector & Pluta-Olearnik [2018] \\
\hline Analysis at country, region/cluster level & $\begin{array}{l}\text { Godlewska-Dzioboń, Klimczyk and Witoń [2019]; Polinkevych } \\
\text { [2018]; Zieliński [2018]; Noga [2016]; Skórska [2016]; } \\
\text { Czubała [2015] }\end{array}$ \\
\hline $\begin{array}{l}\text { Analysis at industry level, enterprises } \\
\text { in general }\end{array}$ & $\begin{array}{l}\text { Kłosiewicz-Górecka [2016]; Matusek [2016]; Kłosiewicz- } \\
\text {-Górecka [2015] }\end{array}$ \\
\hline Financial services & Butor-Keler [2019]; Mrozowski [2018]; Świecka [2015] \\
\hline Insurance services & Jabłoński [2018] \\
\hline Food services & Kudlińska-Chylak [2016]; Tul-Krzyszczuk et al. [2015] \\
\hline Hotel services & $\begin{array}{l}\text { Kobylińska [2018]; Pabian [2018]; Walenciuk and Dłużewska } \\
\text { [2018]; Sztorc [2015]; Zontek [2014] }\end{array}$ \\
\hline Tourism & $\begin{array}{l}\text { Koźlak [2017]; Kurtyka-Marcak and Kutkowska [2017]; } \\
\text { Nowotarska-Romaniak [2017]; Reformat [2015]; } \\
\text { Januszewska, Jaremen and Nawrocka [2015] }\end{array}$ \\
\hline Healthcare & Jakubiak [2016] \\
\hline Design thinking services & Studzińska [2017] \\
\hline Trade in services & Stefaniak [2019] \\
\hline Management of services in an enterprise & Bernat [2018]; Wiak [2016] \\
\hline Public services & $\begin{array}{l}\text { Kobylińska [2018]; Frączkiewicz-Wronka and Kozak [2017]; } \\
\text { Czuba [2016]; Kowalczyk [2016]; Ochojski and Baron [2015]; } \\
\text { Baruk [2015]; Kos [2015]; Czuba [2015]; Gądek-Hawlena and } \\
\text { Wróbel [2015] }\end{array}$ \\
\hline Logistic services & $\begin{array}{l}\text { Cichosz et al. [2017]; Antonowicz [2015]; Kruczek, Przybylska } \\
\text { and Żebrucki [2015] }\end{array}$ \\
\hline Educational services & Toczyńska [2015] \\
\hline E-services & Wolny [2015] \\
\hline Meeting and event industry & Berbeka, Borodako and Rudnicki [2015] \\
\hline Purchaser's role in service creation & Szwaljik and Gracz [2017] \\
\hline Success factors in services & Matusek [2015] \\
\hline Open innovations in services & Aas [2016] \\
\hline Beauty services & Zabrocki [2015] \\
\hline Risk management & Martinek-Jaguszewska [2016] \\
\hline Eco-innovation & Goszczyński [2017] \\
\hline
\end{tabular}

Source: Own study based on BazEkon data for 2015-2019 (November).

A detailed review of article references shows that Polish authors largely draw on foreign source literature. Citations referring to Polish authors are less numerous. References often cite authors' own publications falling within the research areas relating 
to the issue of services. The articles analyzed were mainly published in scientific journals published by universities and schools of higher education. However, the number of publications does not make it possible to unambiguously assess the level of interest in this topic on the part of the Polish research community. An intense, broad search for the most promising directions of research is visible. At the same time, an individualistic approach to research can be seen in the Polish research community. There is a low degree of knowledge of topics already developed, and there is often a lack of rationale and critical approach to the concept adopted.

In the majority of works (with the notable exception of studies presented by researchers such as Noga [2016] and Godlewska-Dzioboń, Klimczyk and Witoń [2019], as well as several publications on innovation in hotel services), aggregated GUS or Eurostat data are simply quoted, already published by those institutions in the form of complete studies and reports.

Many works lack a critical approach to data or independent processing and interpretation of data.

Significantly, most publications concern industries classified as less knowledge-intensive, which, on the one hand, is consistent with the structure of the Polish economy, but, on the other hand, indicates that most researchers do not take on the challenges of studying more difficult, more demanding areas and, having regard to the role of such services in the contemporary economy - more forward-looking.

\subsection{Innovation Level of Polish Enterprises vis-à-vis Other European Countries}

Innovation activities of an enterprise ${ }^{5}$, and, consequently, its innovation level, are affected by many factors, both internal (knowledge, technological, managerial, organizational, cultural conditions) and external (innovation system, national innovation policy, market conditions, functional sources of innovation - recipients, suppliers and subcontractors, other business partners and competitors; institutions of science and technology - universities, scientific and research institutes; institutions

5 "Innovation activities include a range of activities of a scientific (research), technical, organizational, financial and commercial nature, the purpose of which is to develop and implement innovations. Some of these activities and innovative per se, whereas others may lack the element of novelty but be necessary for innovation development and implementation. Innovation activities include also research and development activities which are not related directly to the creation of a specific innovation". See explanations to form PNT-02 for the years 2014-2016, p. 1, http://form.stat.gov.pl/formularze/2017/passive/ PNT-02.pdf (10.01.2020). 
and organizations dedicated to supporting innovation - technology parks, incubators, technology centers; local and regional environment) [Stawasz, 1999, pp. 35-37).

The internal economic conditions affecting innovation and, as a result, business innovativeness, include direct factors: the accumulated human capital stock (knowledge and skills of employees); the accumulated knowledge stock (measured by scientific research expenditure and the size of research staff); stock of materialized knowledge (in the form of machinery and equipment, buildings); external knowledge stock (also acquired through cooperation); organizational resources and factors indirectly linked to the level of innovation, such as the firm's financial resources which affect its ability to finance innovation; the size of the firm, which determines the level of its tangible and intangible resources [Wziątek-Kubiak and Balcerowicz, 2009, p. 17].

Due to the article length limit, two factors will be taken into account in the analysis of innovation activities of Polish service sector enterprises: an internal factor - the level of innovation expenditure, and an external factor: cooperation in innovation activities.

The channels for the paid transfer of knowledge/technologies that the enterprise can use are domestic and international trade in high-tech products ${ }^{6}$, trade in knowledge-based services and trade in patents and licenses [Kuźnar, 2017, p. 81]. International trade in technologically intensive goods is one of the most common methods of technology transfer. In this case, machines or technological lines together with the technology contained in them may be the subject of transaction. This is a relatively quick and least risky way of transferring materialized knowledge.

For its part, cooperation in investment activities relies on cooperative links both between supply chain partners (supplier-recipient relationships) and relationships with other actors in the environment: competitors, complementary suppliers, financial institutions, government agencies, etc. (referred to as $1^{\text {st }}$ and $2^{\text {nd }}$ order relations, respectively - [Fonfara 2004, p. 55]). In this case, it is worth pointing out in particular the growing importance of cooperation with competitors (coopetition) from the perspective of the competitiveness of individual entities and networks. The participants of cooperation are legally independent entities and entities belonging to a corporate group [Donaldson and O’Toole, 2007, pp. 193-198]. Enterprises can cooperate on many levels - both in technological process implementation and in product development, marketing activities or organizational solutions.

The data for the empirical part of the presented analysis is taken from the Community Innovation Survey 2014-2016. The innovation survey and classification method

\footnotetext{
6 Technology transfer may also take the form of product purchase for imitation. However, we will not be addressing this strategy more broadly in this paper.
} 
used to develop the CIS questionnaire is based on the proposals contained in the Oslo Manual [2008], developed by OECD and Eurostat specialists.

For the purposes of these considerations, we assume that innovation is the implementation of a new or significantly improved product ${ }^{7}$ (good or service), or process ${ }^{8}$, a new marketing method ${ }^{9}$, or a new organizational method ${ }^{10}$ in business practices, workplace organization or external relations [Oslo Manual, 2008, p. 46].

The innovation activity survey is conducted for CIS in enterprises classified according to NACE under sections $B$ to $\mathrm{M}^{11}$. It covers the following sections in whole: $\mathrm{B}, \mathrm{C}, \mathrm{D}$, E, G46, H, J, K and M71, M72, M73 (CIS 2016) ${ }^{12}$.

Surveys published by CIS are conducted in enterprises entered in official business registers existing in countries submitting data for CIS purposes, maintained by state statistical offices or institutions appointed for the purpose by government authorities. They involve enterprises employing 10 and more workers; the surveys can be carried out on whole enterprise populations, on random samples, or as compilations of both approaches [CIS, 2016].

7 "A product innovation is the introduction of a good or service that is new or significantly improved with respect to its characteristics or intended uses. This includes significant improvements in technical specifications, components and materials, incorporated software, user friendliness or other functional characteristics". (...) "Product innovations in services can include significant improvements in how they are provided (for example, in terms of their efficiency or speed), the addition of new functions or characteristics to existing services, or the introduction of entirely new services" [Oslo Manual, 2008, p. 48].

8 "A process innovation is the implementation of a new or significantly improved production or delivery method. Process innovations include new or significantly improved methods for the creation and provision of services. They can involve significant changes in the equipment and software used in services-oriented firms or in the procedures or techniques that are employed to deliver services. Examples are the introduction of GPS tracking devices for transport services, the implementation of a new reservation system in a travel agency, and the development of new techniques for managing projects in a consultancy firm" [Oslo Manual, 2008, p. 49].

9 A "marketing innovation" is the implementation of a new marketing method involving significant changes in product design or packaging, product placement, product promotion or pricing. New marketing methods in product promotion involve the use of new concepts for promoting a firm's goods and services. For example, the first use of significantly different media or techniques - such as product placement in movies or television programmes, or the use of celebrity endorsements - is a marketing innovation. Another example is branding, such as the development and introduction of a fundamentally new brand symbol (as distinguished from a regular update of the brand's appearance) which is intended to position the firm's product on a new market or give the product a new image. [Oslo Manual 2008, p. 50).

10 “An organizational innovation is the implementation of a new organisational method in the firm's business practices, workplace organisation or external relations. Organisational innovations can be intended to increase a firm's performance by reducing administrative costs or transaction costs, improving workplace satisfaction (and thus labour productivity), gaining access to non-tradable assets (such as non-codified external knowledge) or reducing costs of supplies” [Oslo Manual, 2019, p. 51].

11 Commission Implementing Regulation (EU) No. 995/2012, Annex II-Innovation Statistics, Section 6.

12 Surveys conducted for CIS do not include sections $\mathrm{O}$ to U, i.e. activities of legal entities and institutions which can be included in sections of the economy such as: public administration, heath service and social assistance, szkolnictwo, culture and arts activities, recreation. On a voluntary basis and less accurately, enterprises belonging to the other sections: A, F, I, N can be studied. See CIS, 2016. 
Next, uniform subgroups are separated from the set of enterprises, and they are stratified according to the type of activities pursued (based on NACE Rev. 2, indicating the nature of activities), regional location (according to NUTS 2 classification) ${ }^{13}$ and size of employment (10-49, 50-249, and 250 and more persons $)^{14}$.

Table 14.3, compiled on the basis of results obtained by CIS for the years 2014-2016, presents the innovation level of the Polish service sector in the context of aggregated data of European Union countries. In general, it can be concluded that both in the case of knowledge-intensive and other industries, innovation activity of Polish enterprises is much below the EU average. The highest percentage of Polish enterprises declaring innovation activity in the sample surveyed was reported in the information and communication section $(\mathrm{J})$ and financial and insurance services section $(\mathrm{K})-22 \%$ of the total population surveyed, slightly lower in the professional, scientific and technical services section $(\mathrm{M})-22 \%$, and wholesale and retail trade, repair of motor vehicles (G) $-17 \%$. The lowest ratings were recorded in the transportation and warehousing section $(\mathrm{H})$ at a mere $11 \%$. By comparison, the respective scores for the EU-28 and EU-15 are as follows: for Section $\mathrm{J}-65 \%$ and 69\%, for Section $\mathrm{K}-55 \%$ and 60\%, for Section $\mathrm{H}-35 \%$ and $40 \%$. No aggregated data are available on Sections G and M. Details of the frequency of ratings for total innovation activities and the introduction of different types of innovation among Polish service sector enterprises against EU data are shown in Table 14.3.

Table 14.3. Innovation level of the Polish service sector vis-à-vis the European Union

\begin{tabular}{|c|c|c|c|c|c|c|c|}
\hline \multirow[b]{2}{*}{$\begin{array}{l}\text { Data for EU28, EU15 and } \\
\text { Poland }\end{array}$} & \multirow[b]{2}{*}{ 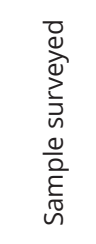 } & \multirow[b]{2}{*}{ 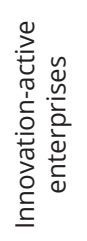 } & \multicolumn{4}{|c|}{ Type of innovation implemented } & \multirow[b]{2}{*}{ 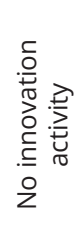 } \\
\hline & & & 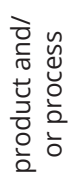 & 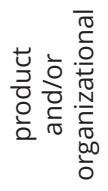 & $\begin{array}{l}\frac{U}{2} \\
\frac{0}{0} \\
\frac{0}{2}\end{array}$ & 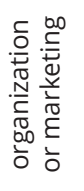 & \\
\hline \multicolumn{8}{|c|}{ WHOLESALE AND RETAIL TRADE; REPAIR OF MOTOR VEHICLES (G) } \\
\hline EU28 & nd & nd & nd & nd & nd & nd & nd \\
\hline EU15 & nd & nd & nd & nd & nd & nd & nd \\
\hline Poland & 11,758 & 2,036 & 822 & 715 & 700 & 498 & 9,722 \\
\hline $\begin{array}{l}\text { Poland (\% of population } \\
\text { surveyed, } N=11,756)\end{array}$ & & 17 & 7 & 6 & 6 & 4 & 83 \\
\hline
\end{tabular}

13 NUTS (nomenclature of territorial units for statistics) is a classification adopted by Eurostat for the purposes of different types of regional statistics. The classification is applied at three levels: NUTS 1, which concerns major regions classified according to socio-economic criteria; NUTS 2, which covers regions where EU-defined regional policies are implemented; NUTS 3, which relates to small regions which are characterized by specific features. See http://epp.eurostat.ec.europa.eu/portal/page/portal/nuts_nomenclature/ introduction (10.01.2020).

14 For more on the Community Innovation Survey questionnaire, see Lewandowska [2018], Appendix 2. 
cont. tab 14.3

\begin{tabular}{|c|c|c|c|c|c|c|c|}
\hline \multirow[b]{2}{*}{$\begin{array}{l}\text { Data for EU28, EU15 and } \\
\text { Poland }\end{array}$} & \multirow[b]{2}{*}{ 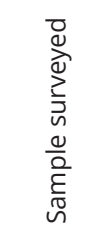 } & \multirow[b]{2}{*}{ 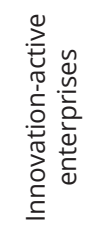 } & \multicolumn{4}{|c|}{ Type of innovation implemented } & \multirow[b]{2}{*}{ 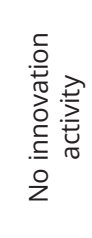 } \\
\hline & & & 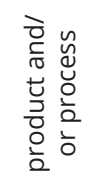 & 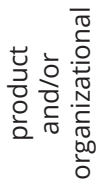 & $\begin{array}{l}\text { ț } \\
\frac{7}{0} \\
0 \\
\text { 을 }\end{array}$ & 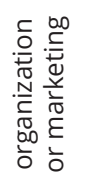 & \\
\hline \multicolumn{8}{|c|}{ TRANSPORTATION AND WAREHOUSING $(\mathrm{H})$} \\
\hline EU28 & 103,948 & 36,099 & nd & nd & nd & nd & 67,848 \\
\hline $\begin{array}{l}\text { EU28 (\% population } \\
\text { surveyed, } N=103,948 \text { ) }\end{array}$ & & 35 & nd & nd & nd & nd & 65 \\
\hline EU15 & 79,252 & 31,981 & nd & nd & nd & nd & 47,270 \\
\hline $\begin{array}{l}\text { EU28 (\% population } \\
\text { surveyed, } \mathrm{N}=79,252 \text { ) }\end{array}$ & & 40 & nd & nd & nd & nd & 60 \\
\hline Poland & 7,549 & 858 & 545 & 173 & 161 & 141 & 6,690 \\
\hline $\begin{array}{l}\text { Poland ( } \% \text { of population } \\
\text { surveyed, } N=7,549 \text { ) }\end{array}$ & & 11 & 7 & 2 & 2 & 2 & 89 \\
\hline \multicolumn{8}{|c|}{ INFORMATION AND COMMUNICATION (J) } \\
\hline EU28 & 65,769 & 42,810 & 10,417 & 25,619 & 28,710 & nd & 22,957 \\
\hline $\begin{array}{l}\text { EU28 (\% population } \\
\text { surveyed, } \mathrm{N}=65,769)\end{array}$ & & 65 & 16 & 39 & 44 & nd & 35 \\
\hline EU15 & 54,944 & 38,147 & 9,045 & 23,157 & 25,652 & nd & 16,796 \\
\hline $\begin{array}{l}\text { EU28 (\% of population } \\
\text { surveyed, } N=54,944)\end{array}$ & & 69 & 16 & 42 & 47 & nd & 31 \\
\hline Poland & 2,681 & 861 & 311 & 338 & 459 & 211 & 1,819 \\
\hline $\begin{array}{l}\text { Poland ( } \% \text { of population } \\
\text { surveyed, } N=2,681 \text { ) }\end{array}$ & & 32 & 12 & 13 & 17 & 8 & 68 \\
\hline \multicolumn{8}{|c|}{ FINANCIAL AND INSURANCE SERVICES (K) } \\
\hline EU28 & 24,874 & 13,802 & nd & 8,024 & nd & 3,400 & 11,069 \\
\hline $\begin{array}{l}\text { EU28 (\% of population } \\
\text { surveyed, } N=24,874 \text { ) }\end{array}$ & & 55 & nd & 32 & nd & 14 & 45 \\
\hline EU15 & 20,288 & 12,219 & 1,988 & 7,205 & 6,492 & 3,019 & 8,066 \\
\hline $\begin{array}{l}\text { EU28 (\% of population } \\
\text { surveyed, } N=20,288 \text { ) }\end{array}$ & & 60 & 10 & 36 & 32 & 15 & 40 \\
\hline Poland & 1,670 & 532 & 230 & 210 & 270 & 92 & 1137 \\
\hline $\begin{array}{l}\text { Poland (\% of population } \\
\text { surveyed, } N=1,670 \text { ) }\end{array}$ & & 32 & 14 & 13 & 16 & 6 & 68 \\
\hline \multicolumn{8}{|c|}{ PROFESSIONAL, SCIENTIFIC AND TECHNICAL SERVICES (M) } \\
\hline EU28 & nd & nd & nd & nd & nd & nd & nd \\
\hline EU15 & nd & nd & nd & nd & nd & nd & nd \\
\hline Poland & 2438 & 542 & 197 & 239 & 213 & 106 & 1896 \\
\hline $\begin{array}{l}\text { Poland ( } \% \text { of population } \\
\text { surveyed, } N=2438 \text { ) }\end{array}$ & & 22 & 8 & 10 & 9 & 4 & 78 \\
\hline
\end{tabular}

Source: Own study based on Eurostat data from Community Innovation Survey 2016. 


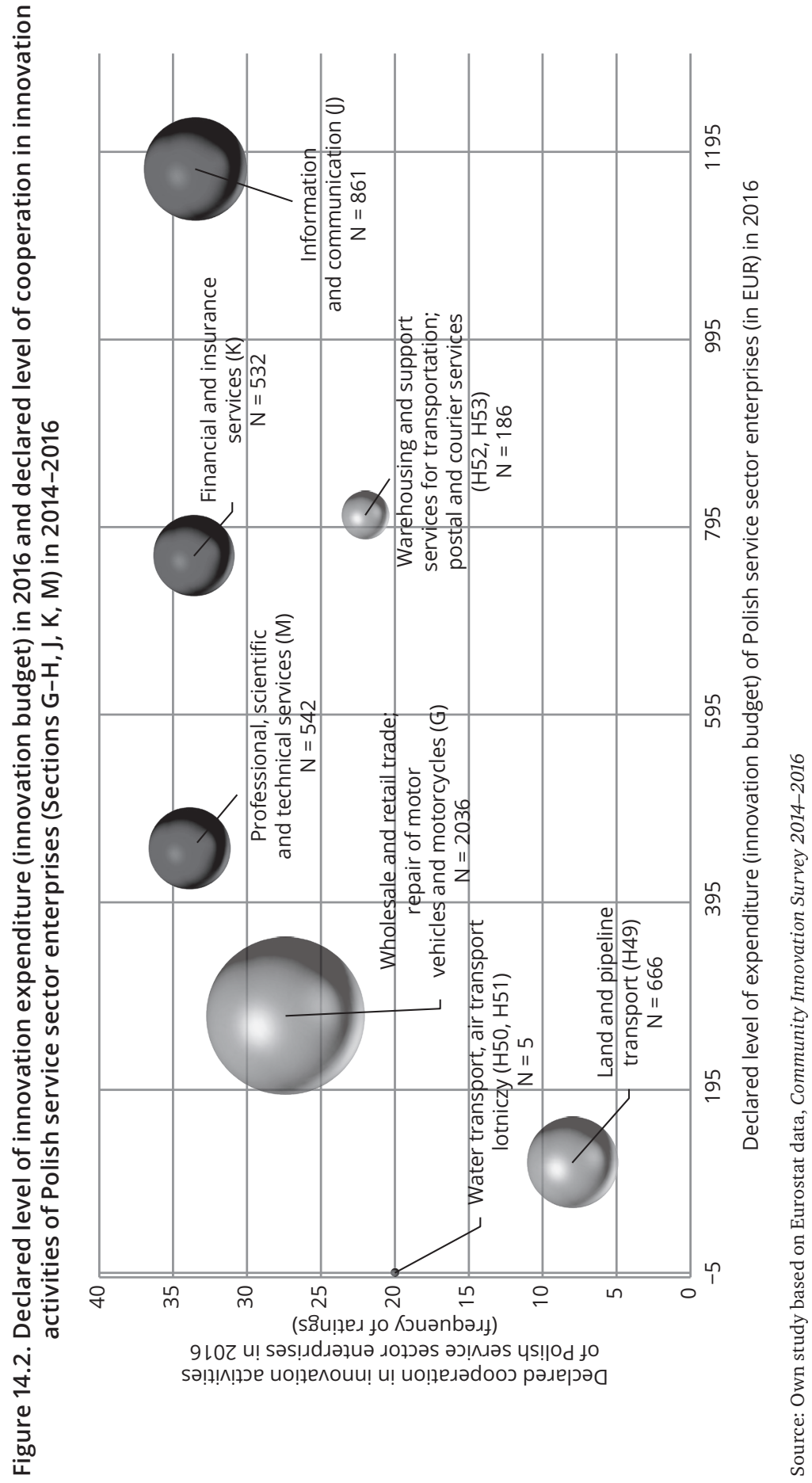




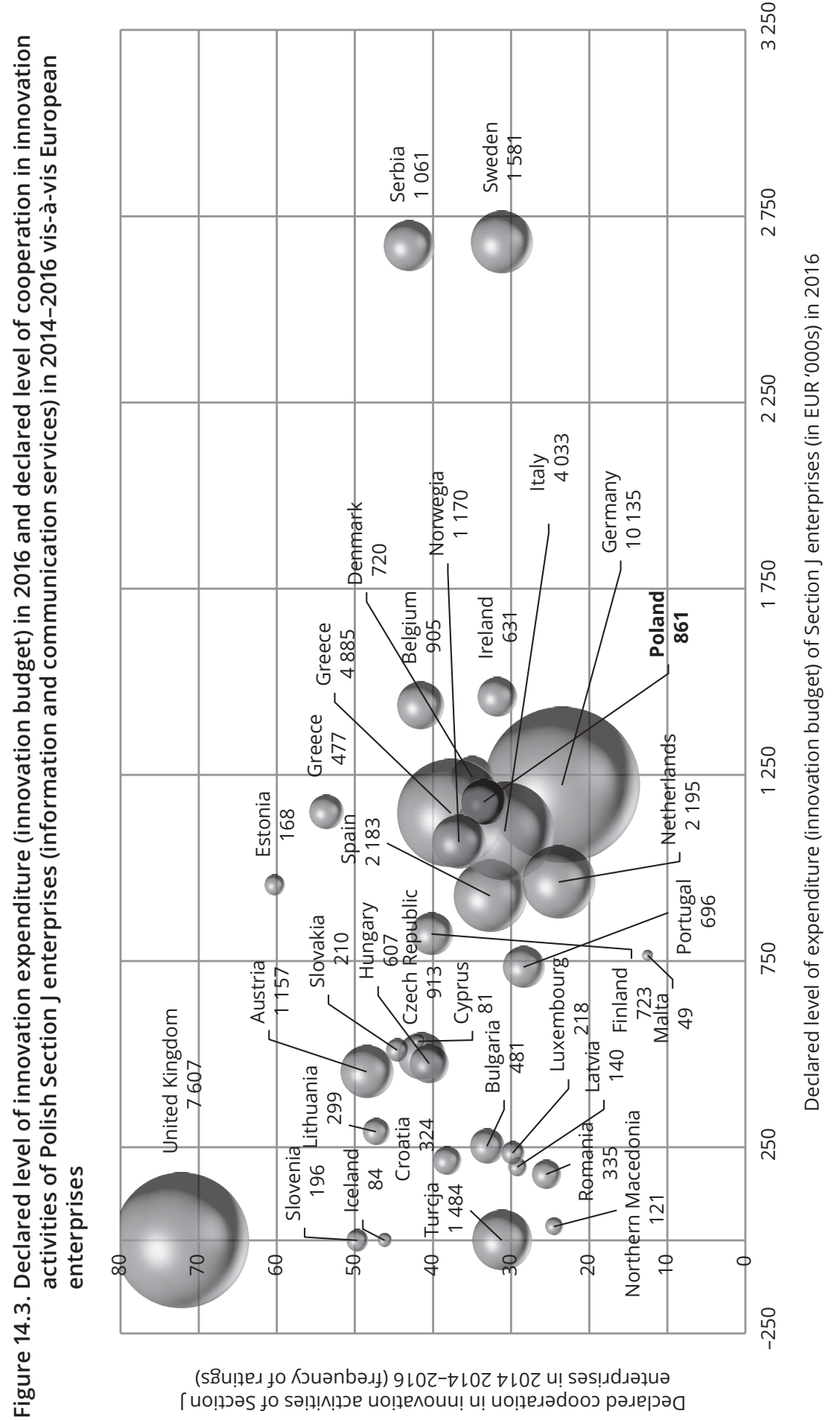

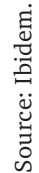




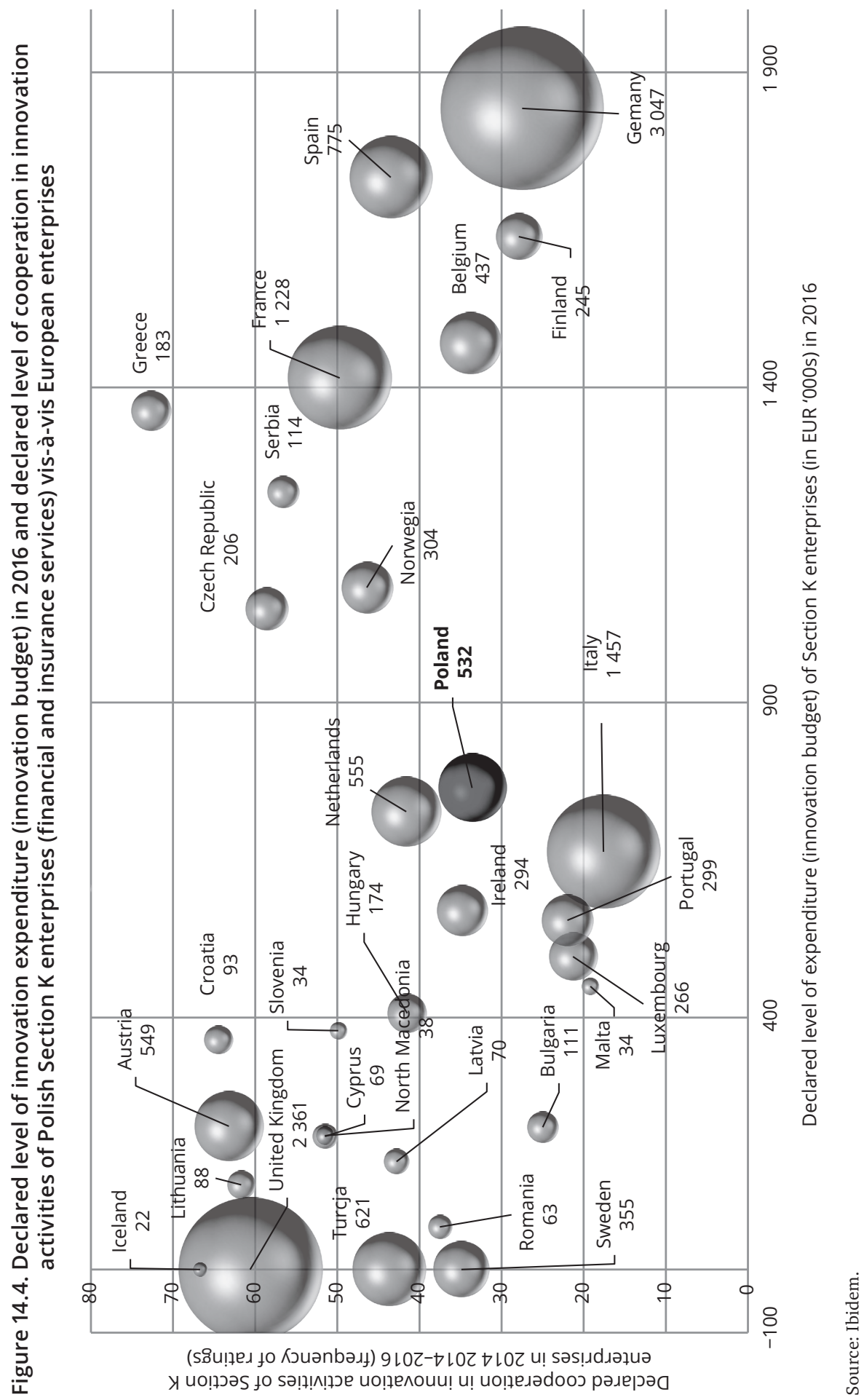




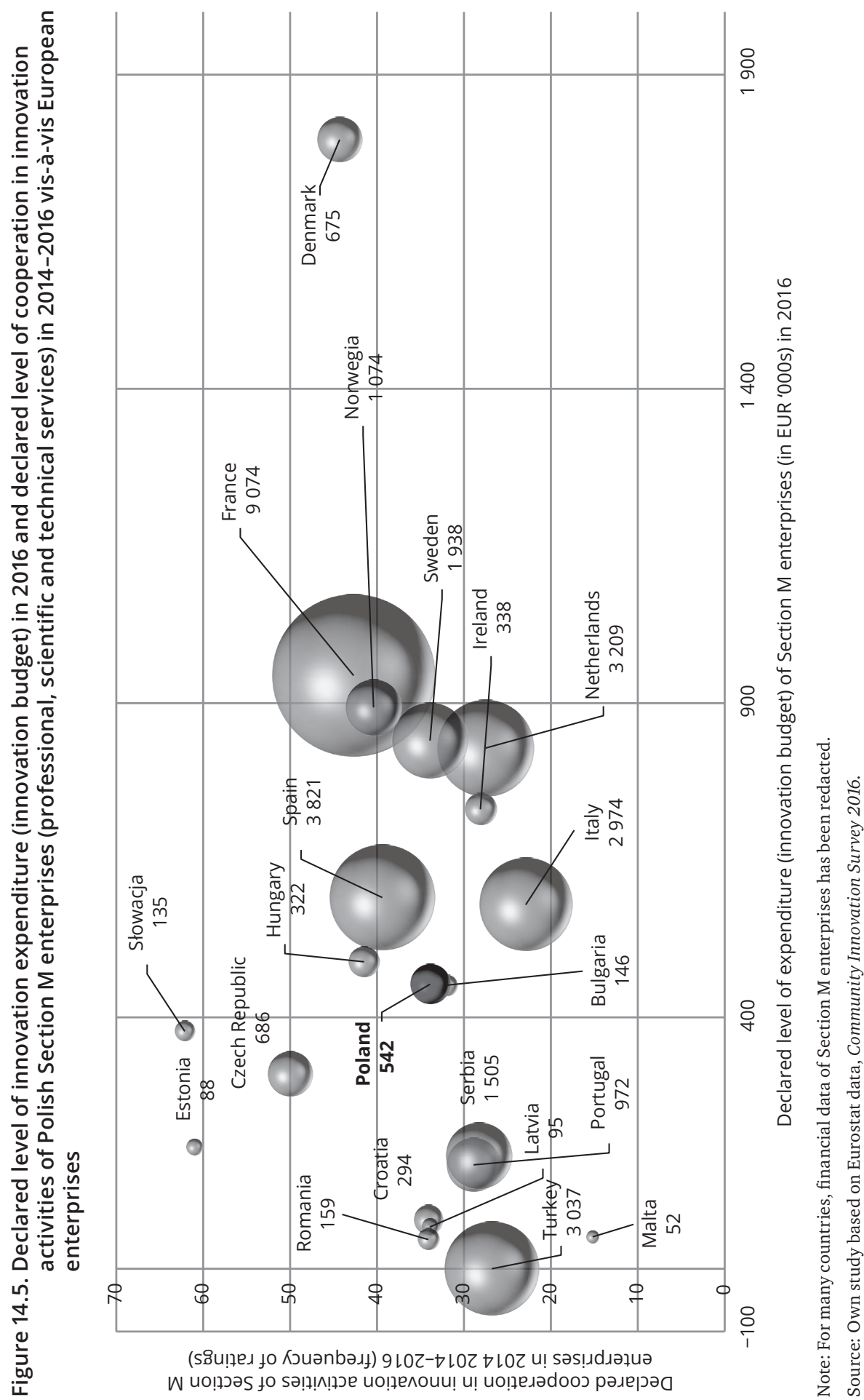


It is worth noting that while Poland is witnessing a shift of employment from industry to services, the service sector nevertheless remains smaller than the EU average, also among the countries of our region (for more on the role of services in Poland's development, see Growiec et al. 2014]. CIS survey sample size data for Poland confirm this state of play.

As already mentioned, due to the article length limit, two factors are taken into consideration in the analysis of innovation activities of Polish service sector enterprises: an internal factor - the level of innovation spending (expenditures on innovation $)^{15}$ of entities that introduced a product and/or process innovation in a given period, or conducted interrupted, abandoned, or uncompleted innovation activities, and one external factor: the level of cooperation in innovation activities declared by enterprises that introduced a product and/or process innovation in a given period, or conducted interrupted, abandoned, or uncompleted innovation activities (rating percentage $)^{16}$.

Figure 14.2 shows seven groups of Polish service enterprises aggregated according to Eurostat recommendations, for which CIS survey data are available for the years 2014-2016. Four of them belong to the group of knowledge-intensive enterprises, whereas three to the group of less knowledge-intensive enterprises.

The size of the circles represents the size of the population of innovative enterprises surveyed (i.e., the percentage of entities that declared the introduction of a product and/or process innovation or conducted interrupted, abandoned or uncompleted innovation activities).

According to data presented in Figure 14.2, groups of enterprises in knowledge-intensive industries ( $\mathrm{J}$ - information and communication services, $\mathrm{K}$ - financial and insurance services, and $\mathrm{M}$ - professional, scientific and technical services) are characterized

15 The data concern financial outlays on innovation activities in 2016 by type of innovation activity and source of funding the expenditure. "The outlays surveyed include "expenditures on innovations", i.e. all expenditure irrespective of sources of funding, both current and capital expenditure, incurred in 2016 for all types of innovation activities, successfully completed work (i.e. resulting in an implemented innovation), interrupted, abandoned and uncompleted by the end of 2016. Such expenditure should be disclosed in the amount actually incurred". See explanations to form PNT-02 for the years 2014-2016, p. 3, http:// form.stat.gov.pl/formularze/2017/passive/PNT-02.pdf (20.01.2020).

16 Cooperation in innovation activities means active participation in joint projects involving innovation activities with other enterprises (other members of a corporate group; suppliers of equipment, materials, components and software; private sector customers; public sector customers; competitors and other enterprises in the same field of activity), or non-commercial institutions (consulting firms (consultants)); commercial laboratories; private R\&D institutions; units of the Polish Academy of Sciences (in the case of Poland); research institutes; foreign public R\&D institutions; domestic and foreign private research institutions; schools of higher education). "Such cooperation may be long-term and forward-looking, and it does not necessarily immediately lead to direct, measurable economic benefits for the partners involved". See PNT 02 form for the years 2014-2016, “cooperation” section, http://form.stat.gov.pl/formularze/2017/ passive/PNT-02.pdf (20.01.2020). 
by a relatively high level of innovation spending (expenditures on innovation) ${ }^{17}$, which is accompanied by a relatively high level of declared cooperation in innovation activity $^{18}$ (on average, $35 \%$ of the total population surveyed). Less knowledge-intensive industries declare a lower level of innovation spending (expenditures on innovation), except H42, H53 - warehousing and support services for transportation, courier services; they are also characterized by a lower level of cooperation in innovation activities. For Polish enterprises, data concerning the water transport and air transport sections (H50, H51) were redacted.

At a further stage of the analysis, three groups of Polish enterprises from the knowledge-intensive service sector (Sections J, K and M), for which full data are available, were compared with enterprises from the EU member states and associated countries, taking into account two previously defined variables - innovation expenditures and the level of cooperation in innovation activities.

In terms of the declared level of innovation expenditure, the Polish information and communication services industry $(\mathrm{J})$ ranks relatively well compared to other EU member states and associated countries. Section J firms from Sweden and Serbia are leading in terms of declared expenditure level. Poland performs the best among the Central and Eastern European countries.

In contrast, in terms of the declared level of cooperation in innovation activities, the Polish section of information and communication services $(\mathrm{J})$ is outranked by other countries. Cooperation leaders are Section J enterprises in the United Kingdom. Financial data concerning this section for Iceland, Slovenia, Turkey, and the United Kingdom were not available, hence their position relative to this variable (the value of 0 was assumed). Details are shown in Figure 14.3.

Figure 14.4 depicts a similar relationship, but it concerns the financial and insurance services section (K). The figure clearly shows that the Polish Section K ranks much worse in terms of the level of declared spending (expenditures on innovation) than firms from other countries, not only the highly developed ones, but also the Czech Republic, Serbia or Greece. Poland also performs poorly, given the level of declared cooperation in innovation activities, which is significantly lower than in most other

\footnotetext{
17 In order to calculate expenditures on innovation per enterprise, expenditures on innovation declared for the whole industry was divided by the number of innovative enterprises which introduced a product and/or process innovation during the period under study. It should be kept in mind that the level of expenditures relative to enterprise size was not taken into account. It is simply the average for the industry in the research period concerned. The broadest category of expenditure was taken into account - expenditures on innovation.

18 It should be noted that in the case of data on cooperation in innovation activity the declared average result for the whole industry was applied. It should also be remembered that the result may be different depending on enterprise size, although the structure of the samples surveys was not analyzed in this case.
} 
countries. Financial data concerning this section for Iceland, Slovenia, Turkey, and the United Kingdom were not available, hence their position relative to this variable (the value of 0 was assumed). Details are presented in Figure 14.4.

When analyzing Figure 14.5, which contains data on Section M (professional, scientific and technical services), it should be noted that both in terms of innovation spending (expenditures on innovation) and the declared cooperation level, Polish enterprises perform worse than many enterprises in Section M of other European countries. For example, the average innovation expenditure of Section M enterprises in Denmark was almost four times higher than that of Polish companies. Unfortunately, data on Section M are redacted by many countries or, as in the case of data for Turkey, there is no financial data (for which a value of 0 is taken). Details are shown in Figure 14.5.

\subsection{Conclusions}

It is difficult to clearly assess the level of innovation of the service sector in Poland. The frequency of ratings concerning innovation activities and introduction of innovations is much below the EU average in Poland - both in the case of knowledge-intensive sections and less knowledge-intensive services.

At the same time, as shown by an analysis of Sections J, K and M, the average level of expenditure on innovation in 2014-2016, while lower than in many other EU member states, especially the developed ones, did not deviate that much from that seen, in particular, in the CEE region. The declared level of cooperation in innovation activities, although much below the EU average, is also not so low as to disqualify Polish firms in the service sector in terms of competitiveness.

So what is the reason for such low innovativeness with moderate but not the lowest expenditures and moderate declared cooperation in innovation activity?

The factors analyzed above are probably not the only major determinants of innovation of Polish enterprises in the service sector. It may be worth referring to the Global Innovation Index (GII), launched in 2011 by a consortium of research organizations, which allows the level of innovation to be compared between economies around the world. It is calculated as the average of the innovation input sub-index and the innovation output sub-index. It also takes into account the ratio of the output sub-index score over the input sub-index score (innovation efficiency ratio). The first sub-index consists of five pillars: institutions, human capital and research, infrastructure, market sophistication and business sophistication. The second sub-index (outputs) involves two types of outputs: knowledge and technology outputs and creative outputs. 
In the GII 2018 ranking, Poland was 39th among more than 140 countries. The innovation input sub-index placed Poland $38^{\text {th }}$, and, in terms of the innovation output sub-index we were ranked $40^{\text {th }}$. This means that innovation system performance in Poland is lower than average The identified weaknesses among innovation inputs include primarily: in the "institutions" pillar - business environment: start-up procedures; in the "infrastructure" pillar - gross fixed capital formation; in the "market sophistication" pillar - micro-finance loan offering and market capitalization as a percentage of gross national product; in the "business sophistication" pillar - cooperation with universities and research centers, total internal R\&D expenditure from external sources [Global Innovation Index, 2018].

The list of such deficiencies is diverse and long. Thus, innovation policy should promote building the absorptive and innovative capacity of enterprises and facilitate access to external sources and innovation financing. The objective should be to eliminate barriers to undertaking and implementing innovations, and to reduce risks and uncertainties inherent in innovation processes [Łokaj and Broszkiewicz, 2018]. An opportunity for such changes is provided by the Innovation Act $^{19}$, which introduces the possibility to deduct $100 \%$ of R\&D costs in the form of R\&D allowance, but its tangible effects are yet to be seen.

It is also important, as advocated in the Dublin Declaration, to disseminate the idea of innovation in Europe and create Open Innovation 2.0 as the concept that underpins the European Union's efforts. However, it should be emphasized that the Declaration mentions the development of an innovation-friendly ecosystem in the form of both open and closed processes. Support for innovation processes from government agencies, supporting cooperation with universities and increasing the role of consumers, users, citizens as potential contributors to innovative solutions, also play an important role in the ecosystem, which contributes, in the long term, to strengthening the diffusional impact of innovation results on other interlinked enterprises [Lewandowska, 2018].

\section{Bibliography}

Aas, T.H. [2016], Open Service Innovation: the Case of Tourism Firms in Scandinavia, "Journal of Entrepreneurship, Management and Innovation", Vol. 12(2), pp. 53-76.

Antonowicz, M. [2015], O innowacjach produktowych i marketingowych $w$ usługach transportowo-logistycznych, "Logistyka", No. 2 (CD 2), pp. 1132-1139.

19 The Act of 9 November 2017 amending certain acts in order to improve the legal environment of innovative activities [Journal of Laws, item 2201), http://prawo.sejm.gov.pl/isap.nsf/download.xsp/ WDU20170002201/T/D20172201L.pdf (20.01.2020). 
Baruk, J. [2015], Wptyw innowacji w usługach publicznych na działalność przedsiębiorstw w Unii Europejskiej, "Wiadomości Statystyczne", No. 6, pp. 83-95.

Berbeka, J., Borodako, K., Rudnicki, M. [2015], Postrzeganie innowacji w branży spotkań przez przedstawicieli krakowskich PCO, "Zeszyty Naukowe Uczelni Vistula”, No. 40, pp. 5-17.

Bernat, P. [2018], Kształtowanie przestrzeni organizacyjnej $w$ kontekście trendów $w$ przemyśle i usługach, "Zeszyty Naukowe Politechniki Śląskiej. Organizacja i Zarządzanie”, No. 118, pp. 70-85.

Butor-Keler, A. [2019], Nowe zagrożenia dla konsumentów wynikające z rozwoju FinTech, "Studia Ekonomiczne Uniwersytetu Ekonomicznego w Katowicach. Ekonomia”, No. 379, pp. 31-45.

Cichosz, M. et al. [2017], Innovation in Logistics Outsourcing Relationship - in the Search of Customer Satisfaction, "LogForum”, Vol. 13(2), pp. 209-219.

CIS [2016], Methodological recommendations, https://circabc.europa.eu/webdav/CircaBC/ ESTAT/infoonstatisticsofsti/Library/methodology/community_innovation/CIS\%202016/ CIS\%202016\%20Methodological\%20recommendations.pdf (8.11.2019).

Czuba, M. [2015], Opportunities and Barriers of Marketing Innovation in Municipal Services Sector, "Forum Scientiae Oeconomia", Vol. 3(3), pp. 77-85.

Czuba, M. [2016], Youth as a Recipient of Marketing Innovations in Activities of Companies Providing Municipal Services, "Forum Scientiae Oeconomia", Vol. 4(1), pp. 45-54.

Czubała, A. [2015], Innowacje w sektorze usług w Polsce, "Zeszyty Naukowe Małopolskiej Wyższej Szkoły Ekonomicznej w Tarnowie”, Vol. 26, No. 1, pp. 35-45.

Dąbrowska, A. [2008], Rozwój rynku usług w Polsce - uwarunkowania i perspektywy, "Monografie i Opracowania", No. 548, p. 349.

Dąbrowska, M. [2011], Innowacje w sektorze ustug, PARP, Warsaw.

Donaldson, B., O’Toole, T. [2007], Strategic market relationships: From strategy to implementation, $2^{\text {nd }}$ edition, John Wiley \& Sons, Chichester.

Eurostat [2008], Statistical classification of economic activities in the European Community, http://epp.eurostat.ec.europa.eu/cache/ITY_OFFPUB/KS-RA-07-015/EN/KS-RA-07-015-EN.PDF (18.01.2020).

Eurostat, https://ec.europa.eu/eurostat (10.01.2020).

Filipiak, B., Panasiuk, A. (eds.) [2008], Przedsiębiorstwo usługowe. Zarządzanie, Wydawnictwo Naukowe PWN, Warsaw.

Fisher, A.G.B. [1939], Economic self-sufficiency, Clarendon Press, Oxford.

Fonfara, K. [2004], Marketing partnerski na rynku przedsiębiorstw, PWE, Warsaw.

Frączkiewicz-Wronka, A., Kozak, A. [2017], Innowacje w usługach publicznych: wspótpraca Rad Działalności Pożytku Publicznego i samorządu terytorialnego, "Przedsiębiorczość i Zarządzanie", Vol. 18, No. 11, Part 1, pp. 219-234.

Gądek-Hawlena, T., Wróbel, M. [2015],The Effects of Innovative Solutions Implemented in the Supply Chain of the Public Postal Operator in Poland, "Zeszyty Naukowe Wyższej Szkoły Bankowej we Wrocławiu”, Vol. 15, No. 1, pp. 35-44.

Global Innovation Index [2019], https://www.globalinnovationindex.org (20.01.2020). 
Godlewska-Dzioboń, B., Klimczyk, P., Witoń, A. [2019], Knowledge-Intensive Services Development in the EU: Forecasts for Selected Countries and Implications for Poland, "Entrepreneurial Business and Economics Review", Vol. 7(2), pp. 101-118.

Goszczyński, T. [2017], Eco-Innovation of Products and Services, "Zeszyty Naukowe Politechniki Częstochowskiej. Zarządzanie", No. 27(1), pp. 132-138.

Growiec, J. et al. [2014], Rola ustug rynkowych w procesach rozwojowych gospodarki Polski, NBP, "Materiały i Studia”, No. 308, https://www.nbp.pl/publikacje/materialy_i_studia/ ms308.pdf (20.01.2020).

http://epp.eurostat.ec.europa.eu/portal/page/portal/nuts_nomenclature/introduction (10.01.2020).

Ilnicki, D. [2009], Przestrzenne zróżnicowanie poziomu rozwoju usług w Polsce. Teoretyczne i praktyczne uwarunkowania badań, Uniwersytet Wrocławski, Wrocław.

Jabłoński W. [2018], Product Innovations and Parameters Concerning Motor Vehicle Insurance and Management Processes Applied by Insurance Companies, "Zeszyty Naukowe Politechniki Częstochowskiej. Zarządzanie", No. 32, pp. 141-149.

Jakubiak, M. [2016], Wdrożenie nowego produktu innowacyjnego na przykładzie programu motywacyjno-zdrowotnego Spirolife, "Zeszyty Naukowe Politechniki Śląskiej. Organizacja i Zarządzanie”, No. 97, pp. 129-139.

Januszewska, M., Jaremen, D.E., Nawrocka, E. [2015], Rola klienta w systemie innowacji przedsiębiorstwa turystycznego, "Logistyka", No. 2 (CD 2), pp. 1487-1495.

Kłosiewicz-Górecka, U. [2015], Innovativeness of Service Sector Enterprises - Innovation Objectives and Types, "Handel Wewnętrzny", No. 5, pp. 176-187.

Kłosiewicz-Górecka, U. [2016], Innowacje w przedsiębiorstwach usługowych, "Marketing i Rynek", No. 5, pp. 2-10.

Kłosiński, A.K. [2011], Światowy rynek usług w początkach XXI wieku, PWE, Warsaw.

Kobylińska, U. [2018], Koprodukcja usług publicznych $w$ świetle przeglądu literatury, "Studia i Prace Kolegium Zarządzania i Finansów SGH", No. 162, pp. 205-218.

Kos, B. [2015], Nowoczesne rozwiązania w usługach publicznych na przykładzie miejskiej karty elektronicznej, "Zeszyty Naukowe Uniwersytetu Szczecińskiego. Problemy Zarządzania, Finansów i Marketingu", No. 40, pp. 147-159.

Kowalczyk, M. [2016], Innowacje technologiczne we wdrażaniu e-ustug dla przedsiębiorstw na przykładzie funkcjonowania Pojedynczego Punktu Kontaktowego, "Studia i Materiały", No. 1, pp. 156-166.

Koźlak, A. [2017], Innowacje $w$ działalności usługowej na przykładzie turystyki, "Współczesna Gospodarka", Vol. 8, No. 4, pp. 97-108.

Kruczek, M., Przybylska, E., Żebrucki, Z. [2015], Znaczenie innowacji w zarządzaniu łańcuchem dostaw, "Zeszyty Naukowe Politechniki Śląskiej. Organizacja i Zarządzanie”, No. 78, pp. 221-233.

Kudlińska-Chylak, A. [2016], Innowacyjne usługi żywieniowe na przykładzie targów śniadaniowych, "Zeszyty Naukowe SGGW w Warszawie. Ekonomika i Organizacja Gospodarki Żywnościowej”, No. 115, pp. 163-170. 
Kurtyka-Marcak, I., Kutkowska, B. [2017], Innovation in Rural Tourism, "Journal of Agribusiness and Rural Development", Vol. 2(44), pp. 383-392.

Kuźnar, A. [2007], Ustugi oparte na wiedzy i ich rola w handlu międzynarodowym. Gospodarka oparta na wiedzy. Aspekty międzynarodowe, D. Rosati (ed.), WSHiP im. Ryszarda Łazarskiego, Warsaw.

Kuźnar, A. [2017], Międzynarodowy handel produktami wiedzy, SGH Publishing House, Warsaw. Lewandowska, M.S. [2018], Koncepcja otwartych innowacji. Perspektywa polskich przedsiębiorstw przemysłowych, SGH Publishing House, Warsaw.

Łokaj, S., Broszkiewicz, A. [2018], Analiza nakładów na działalność badawczo rozwojową w Polsce na tle Unii Europejskiej i perspektywy do roku 2023, PMG Consulting, Kraków, http:// pmgconsulting.eu/wp-content/uploads/2018/09/Analiza-nakladow-na-dzialalnoscbadawczo-rozwojowa-w-Polsce.pdf (10.01.2020).

Majewska, J., Truskolaski, S. [2013], Usługi wiedzochłonne w stymulowaniu innowacyjności w Polsce, "Gospodarka Narodowa", No. 1-2, pp. 91-108.

Martinek-Jaguszewska, K. [2016], Zarządzanie ryzykiem $w$ procesie wdrażania innowacyjnych ustug - przegląd literatury i konceptualizacja modelu, "Studia i Prace Kolegium Zarządzania i Finansów SGH", No. 151, pp. 163-189.

Matusek, M. [2015], Innowacje usług $w$ przedsiębiorstwach produkcyjnych - czynniki sukcesu, "Zeszyty Naukowe Politechniki Śląskiej. Organizacja i Zarządzanie”, No. 83, pp. 427-436.

Matusek, M. [2016], Innowacje usług w przedsiębiorstwach produkcyjnych - jak uniknąć „paradoksu usług", "Organizacja i Kierowanie”, No. 2, pp. 87-103.

Mrozowski, P. [2018], Wpływ branży FinTech na konkurencyjność polskiego sektora bankowego, "Zeszyty Naukowe Wyższej Szkoły Ekonomiczno-Społecznej w Ostrołęce”, No. 28, pp. 197-211.

Niedzielski, P., Rychlik, K. [2007], Innowacje w sektorze produkcyjnym i usługowym - Odmienność czy podobieństwo?, "Zeszyty Naukowe Uniwersytetu Szczecińskiego", No. 453(8), pp. 177-186.

Noga, M. [2016], Innovations in the Service Sector in Poland and the World, „Zeszyty Naukowe Wyższej Szkoły Bankowej w Poznaniu", Vol. 69(4), pp. 73-86.

Nowotarska-Romaniak, B. [2017], Nowe koncepcje marketingu w ustugach turystycznych, "Prace Naukowe Uniwersytetu Ekonomicznego w Katowicach. Innowacje w turystyce: wybrane praktyki działań", pp. 163-174.

Objaśnienia do formularza PNT-02 za lata 2014-2016 (Explanations to Form PNT-02 for the years 2014-2016), http://form.stat.gov.pl/formularze/2017/passive/PNT-02.pdf (18.01.2020).

Ochojski, A., Baron, M. [2015], Innovation in Public Services: the Pursuit of Economic Drivers, "Journal of Economics and Management", No. 19, pp. 173-180.

Osiadacz, J. [2012], Innowacje w sektorze usług - przewodnik po systematyce oraz przykłady dobrych praktyk, PARP, Warsaw. 
Oslo Manual [2008], Guidelines for Collecting and Interpreting Innovation Data, 3 rd edition, OECD/Eurostat, https://www.oecd-ilibrary.org/docserver/9789264013100-en.pdf?exp ires $=1597695965 \& \mathrm{id}=\mathrm{id} \&$ accname $=$ guest $\&$ checksum $=062 \mathrm{D} 8 \mathrm{~A} 452 \mathrm{~B} 25282855 \mathrm{AF} 6 \mathrm{D} 8$ 9401350BB (20.01.2020).

Pabian, B. [2018], Granice innowacji w turystyce kulturowej, "Prace Naukowe Uniwersytetu Ekonomicznego w Katowicach. Kierunki rozwoju innowacji w turystyce”, pp. 9-15.

Pichlak, M. [2015], Innowacje ustugowe - próba konceptualizacji, "Zeszyty Naukowe Politechniki Śląskiej. Organizacja i Zarządzanie”, No. 78, pp. 367-377.

PKWiU [2015], https://krdp.pl/files/aktyprawne/534(1).pdf (20.01.2020).

Pluta-Olearnik, M. [2018], Rozwój innowacji w usługach - perspektywa dostawcy i klienta, "Prace Naukowe Uniwersytetu Ekonomicznego w Katowicach. Nowe koncepcje w nauce o marketingu i rynkach: księga jubileuszowa dedykowana Profesorowi Leszkowi Żabińskiemu", pp. 149-158.

Pluta-Olearnik, M., Wrona, S. (eds.) [2014], Wybrane uwarunkowania rozwoju ustug, Wydawnictwo Uniwersytetu Ekonomicznego, Wrocław.

Pluta-Zaremba, A. [2017], Rozwój usług logistycznych implikowany dynamicznym wzrostem rynku e-commerce, "Studia Ekonomiczne Uniwersytetu Ekonomicznego w Katowicach. Zarządzanie", No. 321(10), pp. 83-99.

Polinkevych, O. [2018], Role of the Service Sector in the Innovation Development of Poland and Ukraine, "Roczniki Ekonomiczne Kujawsko-Pomorskiej Szkoły Wyższej w Bydgoszczy", Vol. 19(11).

Reformat, B. [2015], E-turystyka i uwarunkowania jej rozwoju w Polsce - wybrane aspekty analizy, "Studia Ekonomiczne Uniwersytetu Ekonomicznego w Katowicach", No. 215, pp. 74-89.

Rudawska, I. (ed.) [2009], Ustugi w gospodarce rynkowej, PWE, Warsaw.

Skórska, A. [2012], Wiedzochłonne usługi biznesowe w Polsce i innych krajach Unii Europejskiej, Wydawnictwo Uniwersytetu Ekonomicznego, Katowice.

Skórska, A. [2013], Uwarunkowania rozwoju sektora usług, Wydawnictwo Uniwersytetu Ekonomicznego w Katowicach, Katowice.

Skórska, A. [2016], Innowacyjność sektora usług w Polsce, "Studia Ekonomiczne Uniwersytetu Ekonomicznego w Katowicach. Ekonomia”, Vol. 272(5), pp. 153-164.

Stawasz, E. [1999], Innowacje a mała firma, Wydawnictwo Uniwersytetu Łódzkiego, Łódź.

Studzińska, M. [2017], Narzędzie wspomagające projektowanie usług design-thinking, "Zeszyty Naukowe Politechniki Śląskiej. Organizacja i Zarządzanie”, No. 113, pp. 469-476.

Świecka, B. [2015], Płatności mobilne jako innowacje na rynku detalicznych płatności bezgotówkowych, "Problemy Zarządzania", Vol. 1(54), pp. 29-40.

Szczukocka, A. [2013], Statystyczna ocena znaczenia sektora usług w gospodarce Polski, Wydawnictwo Uniwersytetu Łódzkiego, Łódź.

Sztorc, M. [2015], Wpływ innowacyjności na konkurencyjność przedsiębiorstw ustugowych hoteli, “Zeszyty Naukowe Firma i Rynek", Vol. 48(1), pp. 117-143. 
Szwajlik, A., Gracz, L. [2017], The Use of Consumer Voice in the Process of Service Innovation Creation, "European Journal of Service Management", Vol. 21(1), pp. 59-66.

Toczyńska, J. [2015], Innowacyjność usług edukacyjnych i uczelni, "Zeszyty Naukowe Politechniki Śląskiej. Organizacja i Zarządzanie", No. 78, pp. 457-474.

Tul-Krzyszczuk et al. [2015], Innowacyjne rozwiazania $w$ zakresie kształtowania usług gastronomicznych $i$ zwiazanej z nimi komunikacji rynkowej, "Journal of Agribusiness and Rural Development", Vol. 3(37), pp. 575-580.

Ustawa z dnia 9 listopada 2017 r. o zmianie niektórych ustaw w celu poprawy otoczenia prawnego działalności innowacyjnej [Act of 9 November 2017 amending certain acts in order to improve the legal environment of innovation actiivities] (DzU 2017, item 2201), http://prawo.sejm.gov.pl/isap.nsf/download.xsp/WDU20170002201/T/D20172201L. pdf (10.01.2020).

Węgrzyn, G. [2015], Innowacje w sektorze usług a zmiany strukturalne w zatrudnieniu, Wydawnictwo Uniwersytetu Ekonomicznego, Wrocław.

Wiak, S. [2016], Projektowanie innowacyjnych usług - skuteczne metody wykorzystywane przez organizacje, "Studia i Prace Kolegium Zarządzania i Finansów SGH”, No. 151, pp. 137-161.

Wolny, R. [2015], Innowacyjność podmiotów na wschodzacych i wzrastających rynkach e-usług, "Marketing i Rynek", No. 2 (CD), pp. 109-119.

Wosiek, R. [2018], Innowacje $w$ ustugach: nowy paradygmat $w$ dobie obecnej rewolucji technologicznej, "Studia Ekonomiczne Uniwersytetu Ekonomicznego w Katowicach", No. 352, pp. 278-286.

Wyszkowska-Kuna, J. [2016], Usługi oparte na wiedzy, Wydawnictwo Uniwersytetu Łódzkiego, Łódź.

Wziątek-Kubiak, A., Balcerowicz, E. [2009], Determinanty rozwoju innowacyjności firmy w kontekście wyksztatcenia pracowników, PARP, Warsaw, https://www.parp.gov.pl/storage/publications/pdf/2009_determinanty_rozwoju_innowacyjnosci_wyksztalcenie.pdf (20.01.2020).

Zabrocki, R. [2015], Poradnictwo żywieniowe, jako innowacyjny komponent pakietu ustugowego gabinetów kosmetycznych, "Handel Wewnętrzny", No. 2, pp. 432-443.

Zięba, M. [2013], Knowledge-Intensive Business Services (KIBS) And Their Role in The KnowledgeBased Economy, GUT FME Working Paper, Series A, No. 7.

Zieliński, P. [2018], Stan i perspektywy działalności proinnowacyjnej w sektorze usługowym $w$ Polsce, "Studia i Materiały. Miscellanea Oeconomicae", 22, Vol. 2(3), pp. 357-367.

Zontek, Z. [2014], Innowacje usługowe na przykładzie usług turystycznych, Wydawnictwo Naukowe Wydziału Zarządzania Uniwersytetu Warszawskiego, Warsaw. 

Summary 



\title{
Competitive Position of Poland in 2019 (with a Focus on the Competitiveness of the Service Sector)
}

\author{
Marzenna Anna Weresa, Arkadiusz Michał Kowalski
}

The first quarter of 2020, when we put this monograph into print, brought a huge turbulence to the global economy caused by the COVID-19 pandemic. On 11 March 2020, the World Health Organization announced the highest level of health alert. Like many other countries, Poland took measures in a bid to curtail the spread of the coronavirus. The state of epidemic emergency effective from 14 March 2020 is now one of the key factors affecting the competitiveness of the Polish economy. The most important measures related to the constraints imposed are the restriction of international mobility of people, the reinstatement of controls at all borders, the suspension of international transport links, the restriction of the activities of shopping centers, restaurants, bars and clubs, and the introduction of a ban on gatherings of more than 50 people. As a result, firms have instructed large numbers of workers to work remotely, and some industries (e.g., transport, tourism, hotel, food services) started to be heavily affected by the restrictions imposed. This concerns especially service industries, which have been the subject of analysis in this Competitiveness Report. Poland, as well as the world economy at large, has begun to experience a crisis, one of its signs being disruptions in global financial markets. The effects of the preventive measures taken by governments to control the spread of the COVID-19 virus are felt on both the supply and demand sides [Demertzis et al., 2020, p. 4].

The state of epidemic emergency opened up a completely new situation across the global economy and in individual countries. Enterprises have launched business continuity planning and setting up crisis management structures. The COVID-19 pandemic could affect the global economy in several areas such as production of goods and services, supply chain and market disruption, and financial impact on firms and financial markets [Bachman, 2020]. The epidemic hazard in the East Asian region, in particular in China, has triggered a range of turbulent effects since its emergence, sometimes leading to breaking global value chains. Europe and the United States are expected to plunge into deep recession in 2020 [McKinsey, 2020, p. 13]. 
Against this background, the 2019 economic performance, which is the subject of the analyses in this monograph, appears very good, even though the world economy experienced some slowdown during the period. At that time, the rate of global economic growth was $2.3 \%$, less than in 2017-2018, when a growth of more than $3 \%$ was witnessed. Poland also saw a slowdown of economic growth by around $1 \mathrm{pp}$ in 2019 compared to the previous year. The GDP growth rate in Poland reached 4.1\% in 2019 and it was higher than in most EU countries in the Central and Eastern Europe region. However, Poland lost its position as a leader in economic growth in the CEE group - in 2019 it was Hungary that enjoyed the fastest growth (4.6\%) in the region. Nevertheless, the relatively high rate of GDP growth in Poland translated into a continuation of the process of real convergence to the more developed countries of Western Europe. And although the pace of catching up slowed between 2011 and 2019, the developmental divide between Poland and the EU-15 narrowed in 2019 compared to the previous year by 2 pp. Estimates from the International Monetary Fund show that in 2019 GDP per capita (in PPP) in Poland represented 68\% of the average GDP in the EU-15'.

In addition to the traditional dimensions of competitiveness of economies, such as the level of prosperity measured by GDP per capita, productivity or competitive advantages in trade, inclusive development is also an important aspect, which is measured by income inequality and poverty level. The analyses presented in this monograph show that there is a gradual decrease in income disparity in Poland. In 2018, income inequality measured by the Gini coefficient ranged at $27.68 \%$ and it was lower than the EU average of $30.9 \%$. Likewise, the risk of poverty was then $2.3 \%$ lower than the EU average, but it should be noted that the rate has remained at a similar level since 2009. This means that Poland's competitive position in terms of the social dimension of competitiveness is higher than when measured exclusively by GDP-based indicators.

Another measure of social progress, which covers a wider range of issues than the Gini coefficient, is the Social Progress Index (SPI). It takes into account both the social dimension of competitiveness and achievements in natural environment protection. The value of the index results from the following three criteria: basic human needs, foundations of well-being, and opportunities for personal development [Porter et al., 2017, pp. 16-18]. The index is complementary to prosperity indicators based on national income per capita.

In 2019, Poland ranked $33^{\text {rd }}$ among 149 countries in terms of the Social Progress Index. When comparing Poland in terms of the social and ecological dimension of competitiveness measured by the SPI index with other EU countries in the Central and Eastern European region, it should be noted that, as in previous years, Slovenia,

1 For more on this topic, see Chapter 3. 
the Czech Republic and Estonia performed better than Poland. In addition, in 2019 Poland was also outperformed by Lithuania. On the other hand, the comparison of Poland's rankings against 149 countries analyzed from the point of view of both the SPI index and GDP per capita indicates a relatively higher level of social development of Poland compared to the country's economic development (SPI 2019).

In order to determine Poland's competitive position in the service sector, this monograph has presented the results of an analysis of the change in the importance of services in the economy, competitive advantages in foreign trade in services, and examined the link between the activity of foreign investors in the service sector and the international competitiveness of the Polish economy in this sector. These analyses show that since 2004 the share of the service sector in the Polish economy (NACE sections $\mathrm{G}$ to $\mathrm{U}$ ), measured by value added, remained stable below $65 \%$, at a similar level as in the Czech Republic and Slovakia, but below that level achieved by Western European countries. France leads the way in the EU, with services accounting for almost $80 \%$ of gross value added.

The international competitiveness of the Polish service sector, measured by changes in the value of exports and imports and the balance of trade in services, improved between 2010 and 2019. The growth rate of service exports exceeded that of imports, which consequently translated into an almost seven-fold increase in the surplus of foreign trade balance in services, finally reaching PLN 92.3 bn in 2018. Poland achieved the highest comparative advantages in accounting services, tax consultancy services, and R\&D, construction, legal, and IT services. On the other hand, the greatest comparative disadvantages in trade were reported in intellectual property use, sea transport, financial, insurance, and business consultancy services (cf. Chapter 6). It is hard to predict, however, if the tendencies will be maintained in the context of the slowdown of international trade in services due to the state of epidemic emergency imposed in most countries.

The third area of service competitiveness analyzed in this monograph refers to the impact of foreign investor activity on the development of the service sector. The literature on the subject indicates the positive impact of foreign direct investment in services on the host economy, including knowledge transfer, stimulating employment or GDP growth, but the empirical study has failed to confirm a statistically significant impact in the case of Poland (cf. Chapter 7).

Taking into account the significance of institutional factors in shaping competitive advantages in the context of development of the service sector, the assessment of the key directions of economic policy in Poland in Chapter 8 has made it possible to diagnose key challenges for economic policy in this area. A fundamental weaknesses of the Polish economic policy is the lack of vision of the model of capitalism that best suits the 
conditions and development aspirations of Poland. The lack of a precise definition of the objective of systemic transformation has led to the creation of a "patchwork" institutional architecture, the individual parts of which come from different institutional orders, are internally inconsistent, and show a low degree of complementarity. One of the developmental challenges is the risk of perpetuating Poland's peripheral position in the European Union, in which the country would primarily serve as a producer of few complex goods and subcontractor of more technologically advanced products in global networks of transnational corporations. Another weakness is also the strong redistributive bias in public spending policy at the expense of development expenditure and the overly extensive scope of state functions, which is reflected in the share of public expenditure in GDP being about twice as high as in countries with a level of economic development similar to Poland's.

The determinants of the evolution of the economic model in a given country, affecting growth dynamics of the service sector, include investment outlays. The research presented in this monograph shows that domestic funds were the main source of financing investment in Poland until the end of 2019, whereas the inflow of foreign capital was steadily decreasing. At the same time, a slowdown in the growth rate of investment was witnessed, which was due to a combination of exo- and endogenous factors. What posed a significant constraint to the private sector investment dynamics was the high level of risk associated with possible changes to the tax system, along with the aggravation of disruptions in the functioning of control mechanisms of the tax administration. Optimistic prospects for development of the service sector are also affected by a protracted decision-making process related to changes in the amount of social security contributions remitted by workers hired under contracts of employment. This applies, in particular, to financial and business services as well as IT and computer game production industries, in which a possible repeal of the limit of 30 times the average wage could translated into a significant increase in the cost of doing business. Exogenous factors affecting the declining investment activity of enterprises include the precarious situation among Poland's main trading partners, particularly the German economy, which found itself on the brink of recession in 2019.

In recent decades, developed economies have seen an increase in the share of highly-skilled workers in total employment due, among other things, to structural changes and an increase in the share of jobs in the service sector, in particular in industries offering access to knowledge-intensive services. Between 2008 and 2018, there was a significant increase in the share of highly-skilled workers in total employment in Poland, accompanied by a relative decrease in the share of medium and low-skilled workers. However, industry-level analysis and decomposition of changes by professional group showed that highly skilled workers were more sought after in industry 
than in the service sector, and that the labor market is witnessing an increase in the skills of workers rather than polarization of occupations or employment. The most significant gains in employment in the service sector was observed for Wielkopolskie, Pomorskie and Mazowieckie, followed by Małopolskie, Dolnośląskie and Kujawsko-Pomorskie voivodeships. On the other hand, an analysis of total factor productivity (TFP) carried out at industry level by means of growth accounting showed that in 2010-2018, the service industries with the highest TFP growth rates were information and communication, financial and insurance activities, professional, scientific and technical activities, administrative and support service activities. At the same time, no clear differences have been identified in the growth rate of TFP between the service and manufacturing sectors.

With socio-economic development, the importance of the service sector increases, reflecting servitization process in highly developed countries. In this context, an analysis of the long-term dynamics of employment share indicates an increase in the share of the service sector in the structure of the Polish economy from 48.5\% in 1995 to $58.9 \%$ in 2018, the result being in each case below the EU average (of $64.4 \%$ in 1995 and $74.1 \%$ in 2018). At the same time, the development of the Polish service sector is accompanied by shifts in the structure of the sector, expressed by the largest increases in employment in knowledge-intensive services, such as professional, scientific and technical activities, along with activities in the field of administrative and support activities, and information and communication activities. Services of these categories, engaging high-quality labor resources and supporting the development of other industries in the manufacturing and service sectors play a particular role in terms of the competitiveness of the economy. This concerns mainly industries offering access to knowledge-intensive business services, of which computer programming and consultancy activities are the largest and fastest-growing industry. This observation confirms the rapid development of information and communication technology (ICT) activities in Poland, which is increasingly important in terms of competitiveness, as it provides solutions that are applicable in various areas of economic and social life. This is particularly relevant in the context of the state of epidemic emergency associated with the spread of the COVID-19 virus, and intensive research is underway to promote telework, tele-education and telemedicine as widely as possible.

An analysis of the level of innovation of enterprises in the Polish service sector between 2014 and 2016, measured by the Community Innovation Survey, indicates a lower innovation activity of service companies in Poland compared to the EU average. At the same time, the highest percentage (32\%) of Polish enterprises declaring innovation activity was reported in the information and communication $(\mathrm{J})$ and financial and insurance services (K) section, which are classified as knowledge-intensive services. 
This monograph identifies the various barriers experienced by service enterprises, hampering innovation development, which include, in particular, a low-quality regulatory environment and a shortage of highly-skilled workers. On this basis, innovation policy recommendations have been made, according to which it is necessary to invest in vocational education and training and to stimulate the market for $R \& D$ services. It should be noted that while innovation policy is sector-neutral, which means that companies in the service sector should not feel any exclusion in this respect, in reality the support instruments are generally more suited to the needs of industry. A significant part of innovations in services, on the other hand, are non-technological innovations, the implementation of which is largely linked to the need to develop new skills. Constraints to service innovation mentioned by enterprises include the cost of doing business increasing as a result of regulatory changes introduced in recent years, which include an increase in the minimum wage, increase in social security contributions, tax regulations requiring the employment of professional accounting services even in the case of a small scale of activity, etc. In addition, there are a number of barriers which are specific to particular industries. For example, financial enterprises point to restrictions under personal data protection regulations, which prevent them from making full use of advanced technological solutions.

The increase in the importance of the service sector in the global economy translates into the development of international trade in services. This is determined by various factors, such as technological change and reduction of trade costs, demographic trends, increased wealth of societies, and climate change. A special role in this respect is attributed to the development of digital technologies which allow one of the biggest barriers to trade in services to be removed, namely the need to ensure the geographical proximity between the service provider and recipient.

The situation in the global economy linked to the spread of the COVID-19 virus and the state of epidemic emergency declared in most European countries, including Poland, only adds strength to the conclusion formulated in the monograph concerning the need to develop digital technologies in order to stimulate the development of international cooperation in the service sector. These technologies enable users to communicate at a distance, while ensuring health security, and allow the effects of the difficulties facing the world today to be at least partly mitigated. This also applies to the service sector, although unfortunately certain services cannot be provided at all in the pandemic situation. It is not known how long the crisis caused by health insecurity will last and how many people will suffer from the virus infection. However, at an early stage of the pandemic in Europe, its impact on the economy, including the service sector, is already very strong. It is therefore considered essential for the government to take action to mitigate the effects of the health crisis as soon as possible. 
At the time of putting this publication to print, detailed arrangements planned by the government as part of the business aid package were yet unknown. As announced by the Polish Prime Minister on 18 March 2020, the estimated value of the package is PLN 212 bn to be allocated to the following pillars:

1) employment security, i.e. the protection of workers from job loss, and safety net measures in the labor market;

2) aid for business, including credit guarantees, liquidity support and micro-loans, and operating leases for the transport sector, as well as deferral of social security contributions and taxes;

3) support for the medical services industry, in particular increasing expenditure on necessary equipment, instruments, upgrading hospital facilities, and health protection equipment;

4) strengthening the financial system, including a capital and operational package to protect deposits;

5) a public investment program aimed at increasing infrastructure spending, including expenditure for roads and energy transition

At the same time, on 18 March 2020, resolution No. 1/2020 of the Monetary Policy Council entered into force, which set new NBP interest rates:

- reference rate of 1\% per annum, the lowest level since 1989 (down from 1.5\%),

- Lombard rate of $1.5 \%$ per annum (down from $2.5 \%$ ),

- NBP deposit rate of $0.5 \%$ per annum (unchanged),

- rediscount rate of $1.05 \%$ per annum (down from $1.75 \%$ ),

- discount rate of $1.1 \%$ per annum.

The Monetary Policy Council also decided to reduce the minimum reserve ratio (the percentage of deposits that banks must hold with the central bank) from 3.5\% to $0.5 \%$ and to increase the interest rate on funds held as minimum reserve from $0.5 \%$ to the NBP reference rate. The interest rate cut will have an impact on the decrease in the average interest rate on loans and deposits in the Polish currency, but at the same time it may contribute to the increase in inflation (4.7\% in February 2020), which has gone well beyond the inflation target of 2.5\%. Among other reasons, the Monetary Policy Council has justified its decision by similar actions taken by other central banks around the world, including the European Central Bank, the US Federal Reserve System and the Bank of England (central bank of the United Kingdom). However, there is a high risk that the world economy will be strongly affected by the spread of the coronavirus in the coming months, which will contribute to a global socio-economic crisis. 


\section{Bibliography}

Bachman, D. [2020], The economic impact of COVID-19 (novel coronavirus), ttps://www2. deloitte.com/global/en/insights/economy/covid-19/economic-impact-covid-19.html (16.03.2020).

Demertzis, M. et al. [2020], An effective economic response to the coronavirus in Europe', "Policy Contribution", issue 6, March.

McKinsey [2020], COVID-19: Briefing Note. Global Health \& Crisis Response, https://www. mckinsey.com/ /media/McKinsey/Business\%20Functions/Risk/Our\%20Insights/ COVID\%2019\%20Implications\%20for\%20business/COVID\%2019\%20March\%2016/ COVID-19-Facts-and-Insights-March-16- ${ }^{3}$.ashx (16.03.2020).

Porter, M., Stern, S., Green, M. [2017], Social Progress Index 2017. Social Progress Imperative, Washington, https://www.socialprogress.org/ (18.03.2020).

SPI (2019), 2019 Social Progress Index. Executive Summary, https://www.socialprogress.org/ assets/downloads/resources/2019/2019-Social-Progress-Index-executive-summary$\mathrm{v}^{2}$.0.pdf (18.03.2020).

Resolution No. 1/2010 of the Monetary Policy Council of 17 March 2020 on the reference rate, refinance loan interest rate, term deposit interest rate, rediscount rate and bill discount rate at the National Bank of Poland, Dziennik Urzędowy Narodowego Banku Polskiego, item 4. 


\section{SGH}

\section{SGH SHAPES LEADERS}

SGH Warsaw School of Economics is an innovative economic university that develops intellectual potential and creates leaders in response to the challenges of the future. It is an influential center for academic research, new ideas and initiatives undertaken by the academic community and alumni, as well as by business representatives, NGOs and public administration. As an autonomous and socially responsible university, SGH promotes ethical citizenship through its teaching, research and social engagement activities.

The quality of education gained at the $\mathrm{SGH}$ is widely recognized by employers, who seek to recruit its graduates. SGH awards 1,200 Bachelor's and 1,600 Master's degrees each year. The present educational success of the $\mathrm{SGH}$ and its alumni results from an individualized study program enabled by an innovative structure, in which the faculty members are gathered in five research units called collegia.

$\mathrm{SGH}$ offers numerous international programs conducted in cooperation with foreign partners. One notable example is the University's CEMS (The Global Alliance in Management Education) membership - the world's leading association of business schools, corporate partners and NGOs. CEMS also offers a renowned Master degree in International Management. SGH is also a member of PIM (Partnership in International Management) - the largest international consortium of leading business schools.

Another considerable merit of the University is that both its alumni and its staff have been actively involved in shaping the economic and public spheres in Poland and Europe alike. Some of the most noteworthy examples include a former Polish prime minister and deputy prime ministers, the majority of ministers of finance after 1989, the first Polish commissionaire in the European Commission, two presidents of the National Bank of Poland, members of the Monetary Policy Council, presidents of the Polish Stock Exchange, chairpersons and members of the Polish Financial Supervision Authority, government experts, advisors, as well as specialists serving the European Union, other European institutions, and the UN.

SGH Warsaw School of Economics

tel.: +48225646000

email:info@sgh.waw.pl

www.sgh.waw.pl 


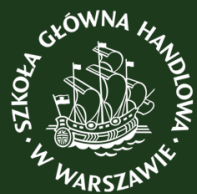

The global economy is witnessing dynamic changes related to the Fourth Industrial Revolution. The latest achievements in information and communication technologies (ICT) have revolutionized manufacturing and services, as well as business practices. The use of new technologies allows an interactive network of products, machines and workforce to emerge, enhances linkages within the value chain, and affects the conditions of competition. Therefore, the question arises about the traditional and new dimensions of competitiveness in the era of digital economy, and their significance for Poland. Seeking an answer to this question is the leitmotif of this monograph.

Digital transformation has important implications for the theoretical approach to competitiveness, expanding it to include a new dimension related to digitalization. Moreover, the need arises to seek new ways of measuring the competitive ability and position. The analyses in this monograph refer both to theoretical issues concerning the competitiveness of economies in the context of the Fourth Industrial Revolution, and to empirical ones, which consist in determining the competitive position of the Polish economy in 2018 compared with other EU member states, taking into consideration the level of advancement of Industry 4.0.

SGH PUBLISHING HOUSE

SGH WARSAW SCHOOL OF ECONOMICS

www.wydawnictwo.sgh.waw.pl

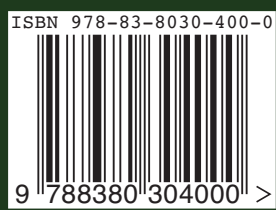

